\title{
Provenance of the Upper Jurassic Norphlet and Surrounding Formations from U-Pb Detrital Zircon Geochronology
}

Andrea Frances Lisi

West Virginia University

Follow this and additional works at: https://researchrepository.wvu.edu/etd

\section{Recommended Citation}

Lisi, Andrea Frances, "Provenance of the Upper Jurassic Norphlet and Surrounding Formations from U-Pb Detrital Zircon Geochronology" (2013). Graduate Theses, Dissertations, and Problem Reports. 3614. https://researchrepository.wvu.edu/etd/3614

This Thesis is protected by copyright and/or related rights. It has been brought to you by the The Research Repository @ WVU with permission from the rights-holder(s). You are free to use this Thesis in any way that is permitted by the copyright and related rights legislation that applies to your use. For other uses you must obtain permission from the rights-holder(s) directly, unless additional rights are indicated by a Creative Commons license in the record and/ or on the work itself. This Thesis has been accepted for inclusion in WVU Graduate Theses, Dissertations, and Problem Reports collection by an authorized administrator of The Research Repository @ WVU. For more information, please contact researchrepository@mail.wvu.edu. 
Provenance of the Upper Jurassic Norphlet and Surrounding Formations from

U-Pb Detrital Zircon Geochronology

Andrea Frances Lisi

\author{
Thesis submitted to the \\ Department of Geology and Geography \\ at West Virginia University \\ in partial fulfillment of the requirements \\ for the degree of
}

\author{
Master of Science \\ in \\ Geology \\ Amy Weislogel, Ph.D., Chair \\ Tim Carr, Ph.D. \\ Jaime Toro, Ph.D. \\ Department of Geology and Geography \\ Morgantown, West Virginia \\ 2013
}

Keywords: Norphlet Formation; Haynesville Formation; Eastern Gulf of Mexico; $\mathrm{U}-\mathrm{Pb}$ detrital zircon geochronology; Suwannee Terrane

Copyright 2013 Andrea Frances Lisi 


\section{Abstract \\ Provenance of the Upper Jurassic Norphlet and Surrounding Formations from U-Pb Detrital Zircon Geochronology}

\section{Andrea Frances Lisi}

$\mathrm{U}-\mathrm{Pb}$ detrital zircon geochronology supplemented by thin-section petrography, dense mineral analysis of samples, and well log analysis from onshore western Florida as well as from the offshore federal lease blocks, Mobile Bay, Pensacola, Destin Dome, St. Petersburg, and Florida Middle Ground are used to constrain the provenance of the Upper Jurassic Norphlet and surrounding formations. Using LA-ICPMS, $867 \mathrm{U}-\mathrm{Pb}$ ages from 10 samples, core and cuttings, were determined. Results show an influence of both Laurentian and peri-Gondwanan Suwannee Terrane derived sediments. Four major $\mathrm{U}-\mathrm{Pb}$ age populations exist in the samples which include 250-500 Ma, 500-700 Ma, 900-1400 Ma, and 1950-2250 Ma. These age populations are coeval with several known tectonic events in the source terranes: Laurentian Appalachian mountain building (Alleghanian, 280-325 Ma, Acadian, 384-425 Ma, Taconic, 430-480 Ma) and Grenville orogenies (900-1300 Ma) and the Gondwanan, Pan-African (500-680 Ma) and TransAmazonian/Eburnean (1900-2250 Ma) events.

To understand sediment distribution in the study area, four geochronologic source areas, based on suites of $\mathrm{U}-\mathrm{Pb}$ age distributions, were identified as possible sources for the Norphlet Formation: Appalachian hinterland, Appalachian foreland basin, Mesozoic rift basin, and the Suwannee Terranne. Only the Mobile Bay sample showed an almost entirely Laurentian suite of $\mathrm{U}-\mathrm{Pb}$ ages. The three samples from the Florida Panhandle showed some mixing of Laurentian and Gondwanan sediments. While the U-Pb age distribution of the Florida Panhandle samples showed a more abundant Laurentian population (250-500 Ma and 900-1300 Ma), a Gondwanan population is also present (500-700 Ma and 1900-2250 Ma). The two samples within the Apalachicola Embayment (i.e., Destin Dome and Pensacola federal lease blocks) have a stronger Gondwanan influence but the Laurentian-aged zircon are still present. The samples from southeastern Gulf of Mexico are past the updip limit of the Norphlet Formation and consist of Paleozoic basement, the Haynesville Formation, and the Cotton Valley Group. Their U-Pb age distribution shows an entirely Gondwanan source with most ages between 500-700 Ma (PanAfrican).

The U-Pb detrital zircon data along with thin-section petrography and dense mineral analysis support previous paleogeographic models that consist of a proximal paleo-high source in which alluvial and wadi facies carry sediment into the eolian system. Point-counting of five samples showed the Norphlet to increase in compositional maturity away from the paleo-high source areas. The Norphlet consists of subarkose in the Florida Panhandle with an average modal abundance of $\mathrm{Q}_{64} \mathrm{~F}_{33} \mathrm{~L}_{3}$ and arkose in the Apalachicola Embayment with an average modal abundance of $\mathrm{Q}_{79} \mathrm{~F}_{15} \mathrm{~L}_{6}$. Dense mineral analysis showed that detrital samples closer to the paleohigh source area have more of the less resistant phyllosilicate material (Florida Panhandle and Mobile Bay) than those more distal (Apalachicola Embayment).

The provenance data also supports the hypothesis of two major fluvial and eolian sediment transport pathways, one to the south in southwestern Alabama and Mobile Bay and 
another to the west in the Apalachicola Embayment. Where these two converging winds meet, deposition of eolian sands occurred in thick deposits along the eastern Mobile Bay and western Destin Dome and Pensacola offshore lease blocks. This sediment distribution pattern is supported through log analysis. These results suggest that major Norphlet discoveries in the deep offshore eastern Gulf of Mexico such as Appomattox, Shiloh, and Vicksburg are predominantly Suwannee-sourced sediments forming along the trend of thick eolian reservoir sandstone. 


\section{Acknowledgements}

I would like to thanks Murphy Oil Corporation for their generous support for whom this project could not have been possible without. I would also like to thank the Oklahoma Geological Survey and Florida Geological Survey for their help with the tedious nature of tracking down and collecting samples. Special thanks to my advisor, Dr. Amy Weislogel, who gave me endless guidance on the project as well as my committee members Drs. Tim Carr and Jaime Toro.

A large amount of assistance was received from within the WVU Geology and Geography Department from several peers who helped with sample preparation, collection, and analysis for which I am ever so grateful; Marcus Jessee, Matt McKay, Fei Shang, Asa Mullenex, Evan Knight, and Katie Flowers. A special thanks to Evan Knight for his work on detrital zircon grain size distribution.

I would also like to thank the folks at the University of Alabama including Dr. Delores Robinson, Thomas Lovell, Lance Wilson, and Bryan Hunt. Their work was paramount to my own. Lastly, I would like to thank my family for their support, especially my husband for all the encouragement and long drives. 


\section{Contents}

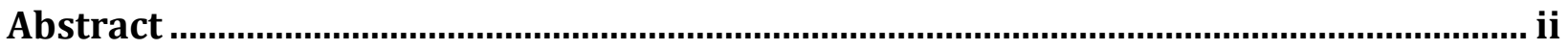

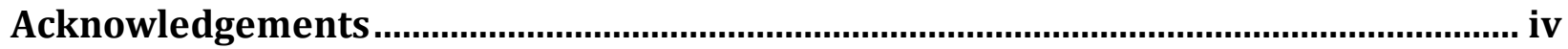

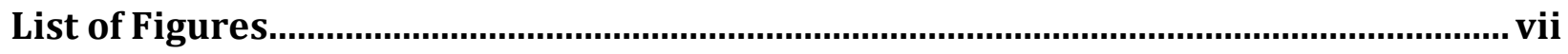

List of Tables .............................................................................................................ii

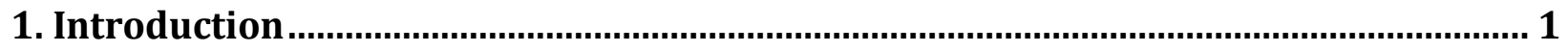

1.2 Research Problem and Significance ............................................................................. 3

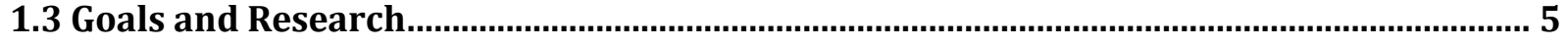

2. Background

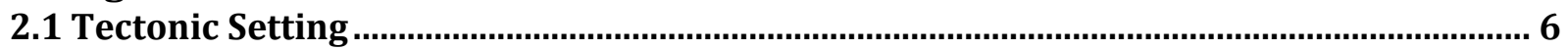

2.2 Depositional Environment and Stratigraphy ……...................................................... 9

2.3 Norphlet Formation Petrology ……………......................................................................12

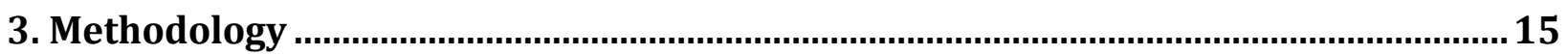

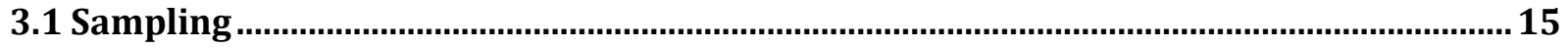

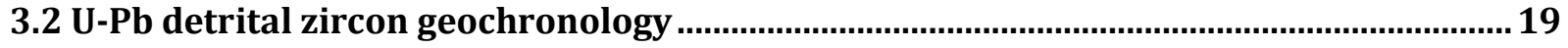

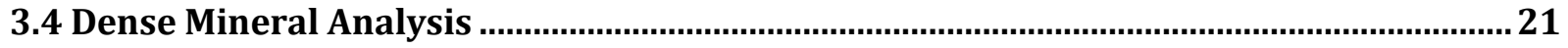

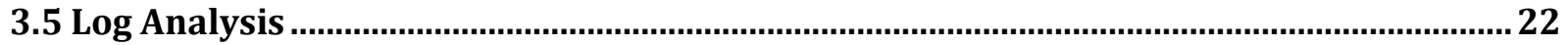

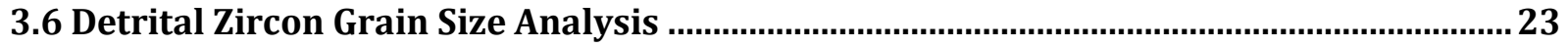

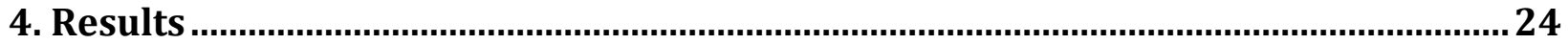

4.1 Sample Descriptions and U-Pb Detrital Zircon Age Distributions......................................24

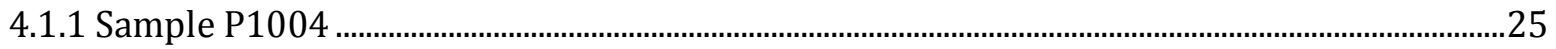

4.1.2 Sample 1096 ................................................................................................................................................26

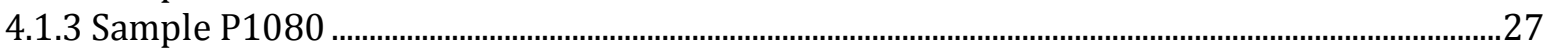

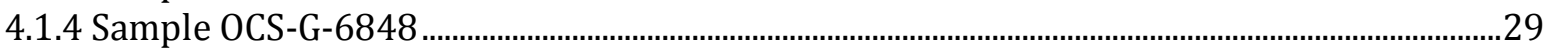

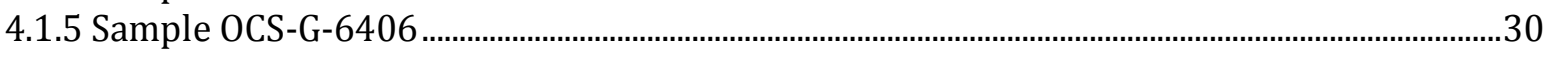

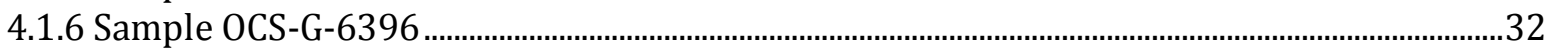

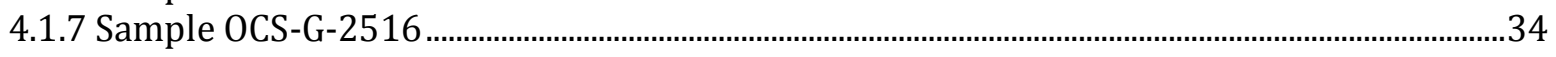

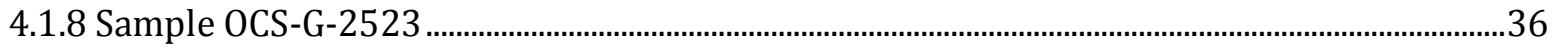

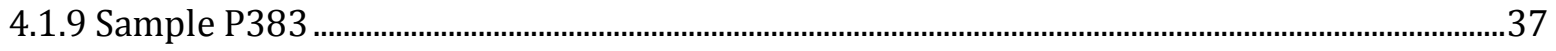

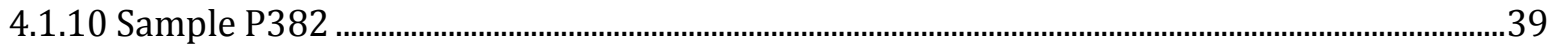

4.2 Shared Age Populations and Peak Age Correlation ..........................................................40

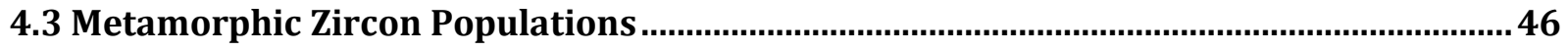

4.4 Regions of Similar U-Pb Age Distribution........................................................................50

4.4.1 Florida Panhandle............................................................................................................................................51

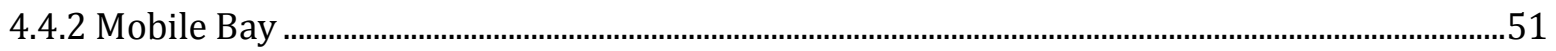

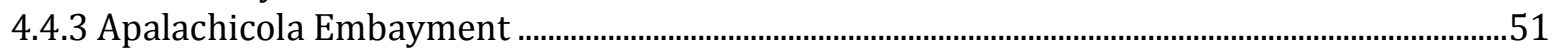

4.4.4 Southeastern Gulf of Mexico......................................................................................................................52

4.5 Grain Size Analysis....................................................................................................... 52

4.6 Norphlet Sandstone Composition ................................................................................. 55

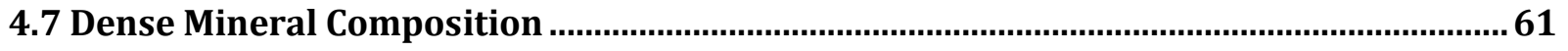

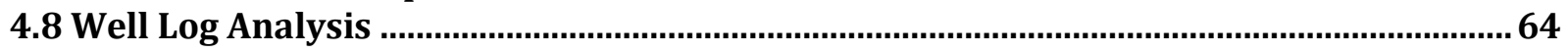

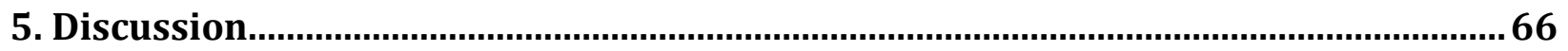

5.1 Possible Source Areas ..................................................................................................66

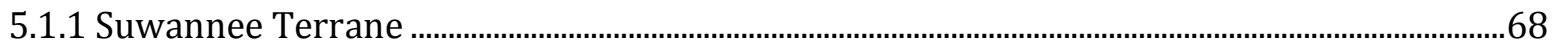




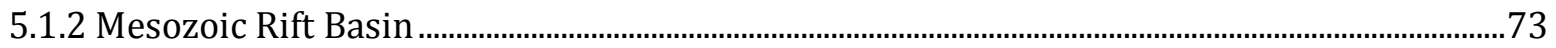

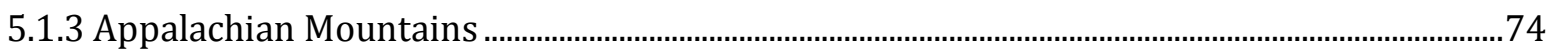

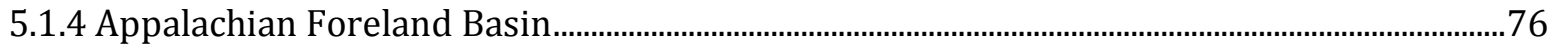

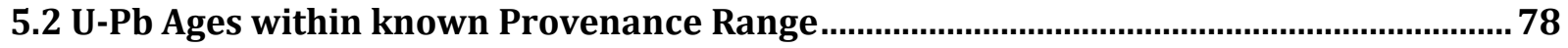

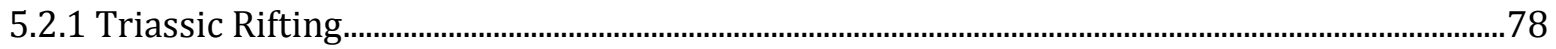

5.2.2 Appalachian Mountain Building

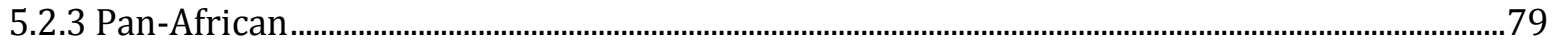

5.2.4 Grenville and the Gondwanan Sunsas and South and Central African Orogenies.................80

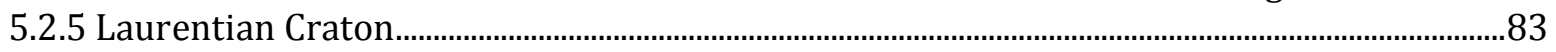

5.2.6 Trans-Amazonian/Eburnean Orogenies........................................................................................84

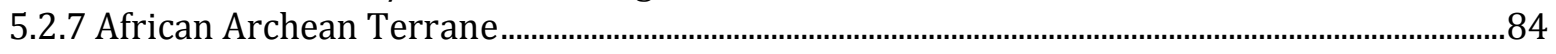

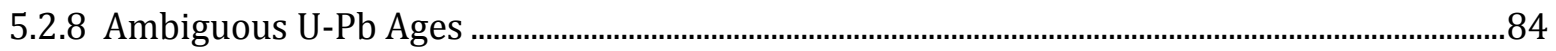

5.3 Geospatial Trends in Norphlet Composition ...................................................................... 86

5.4 Geospatial Trends in Dense Mineral Abundances ........................................................... 91

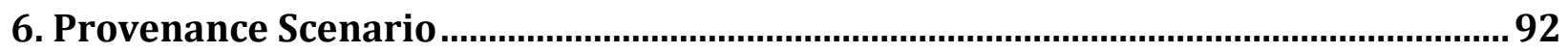

6.1 Primarily Laurentian Affinity: Mobile Bay .......................................................................... 92

6.2 Gondwanan Affinity: Southeastern Gulf of Mexico ….................................................. 93

6.3 Mixed Affinity: Florida Panhandle .................................................................................. 94

6.4 Primarily Gondwanan Affinity: Apalachicola Embayment ..............................................94

6.5 Geographic Extent of Provenance Scenario ........................................................................ 95

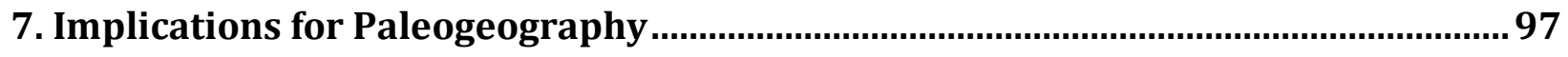

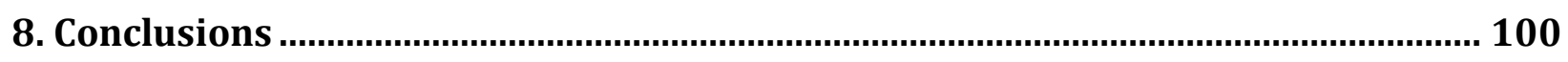

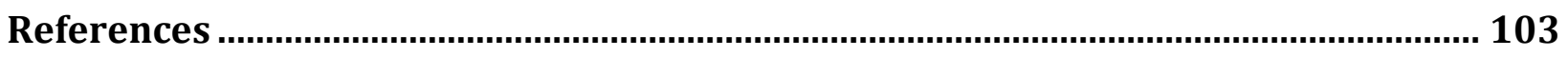

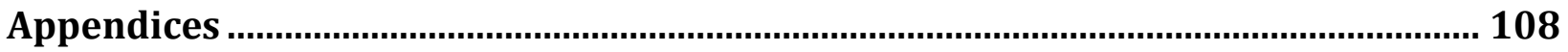




\section{List of Figures}

Figure 1. Eastern Gulf of Mexico and Major Norphlet Producing Fields and Discoveries.......2 Figure 2. Paleogeographic model of the Norphlet Formation in southwest Alabama and the western Florida Panhandle ...................................................................................................................

Figure 3. Study Area .........................................................................................................................

Figure 4. Study Area of Mancini et al. (1985) and Scott (1991).......................................................

Figure 5. Paleogeographic Maps; Middle Triassic-Late Jurassic........................................................7

Figure 6. Paleo-highs and Lows in the Eastern Gulf of Mexico ……………………………….....8

Figure 7. Stratigraphic column of the Eastern Gulf of Mexico (Triassic-Jurassic)........................9

Figure 8. QmFLt Plot of the Norphlet Formation in Southwestern Alabama and the Western

Florida Panhandle .......................................................................................................................13

Figure 9. Location of Samples used for U-Pb Detrital Zircon Geochronology .............................16

Figure 10. Location of Well Control for Log Analysis.....................................................................22

Figure 11. Wetherill Concordia Plot of all 10 Detrital Zicon Samples...........................................24

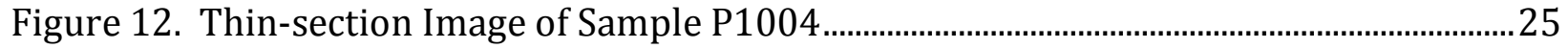

Figure 13. Sample P1004 Relative Probability and Density Plots...................................................25

Figure 14. Thin-section Image of Sample P1096 ………………………………………………..26

Figure 15. Sample P1096 Relative Probability and Density Plots..................................................27

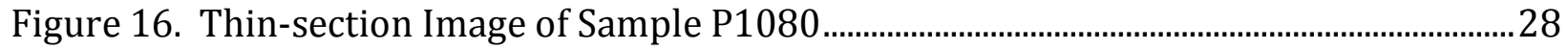

Figure 17. Sample P1080 Relative Probability and Density Plots.................................................28

Figure 18. Sample OCS-G-6848 Relative Probability and Density Plots ......................................30

Figure 19. Image of Core Plug from Sample OCS-G-6406 ...............................................................30

Figure 20. Sample OCS-G-6406 Relative Probability and Density Plots ......................................31

Figure 21. Core Description and Images of Sample OCS-G-6396 ……………….........................33

Figure 22. Sample OCS-G-6396 Relative Probability and Density Plots ......................................34

Figure 23. Thin-section Image of Cuttings from Sample OCS-G-2516 ………………………........

Figure 24. Sample OCS-G-2516 Relative Probability and Density Plots ......................................35

Figure 25. Image of Cuttings from Sample OCS-G-2523 ……………………………...................36

Figure 26. A Sample OCS-G-2523 Relative Probability and Density Plots ....................................37

Figure 27. Thin-section Image of Core Chips from Sample P383...................................................37

Figure 28. A Sample P383 Relative Probability and Density Plots ...............................................38

Figure 29. Thi Thin-section Images of Sample P382 ……………………………………………..39

Figure 30. Sample P382 Relative Probability and Density Plots ....................................................40

Figure 31. Cumulative Relative Probability Plot for all 10 Detrital Zircon Samples ................41

Figure 32. Prominent U-Pb Age Populations and Age Peaks of all Samples................................. 42

Figure 33. Peak U-Pb Ages (200-800 Ma)........................................................................................4

Figure 34. Peak U-Pb Ages (800-1500 Ma) ........................................................................................ 45

Figure 35. Peak U-Pb Ages (1500-2900 Ma) ........................................................................................46

Figure 36. U-Pb Age vs. U/Th Plots ....................................................................................................48

Figure 37. Ages of Metamorphic Zircons....................................................................................49

Figure 38. Location of Samples with Similar Detrital Zircon U-Pb Age Distributions..............50

Figure 39. Detrital Zircon Grain Size Analysis ................................................................................54

Figure 40. QFL Plot of the Norphlet Formation Samples................................................................55

Figure 41. Relative Abundances of Framework Grains ...................................................................56 
Figure 42. Images of Framework Grains in Thin Section .............................................................58

Figure 43. Images of Framework Grain Textures in Thin Section ..............................................60

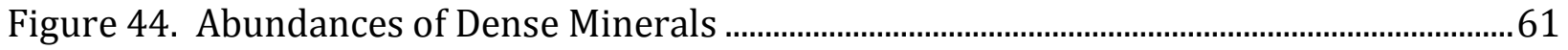

Figure 45. Images of Dense Minerals in Thin Section ..................................................................63

Figure 46. Isopach Map of the Norphlet Formation.....................................................................64

Figure 47. Average Shale Volume Distribution of the Norphlet Formation ...............................65

Figure 48. Relative Probability Plot of all Ten Samples .................................................................67

Figure 49. Four Geochronologic Source Terranes .........................................................................68

Figure 50. Lithology of the Florida Basement...............................................................................69

Figure 51. West African Mauritanides, Bassarides, and Rokelides Orogenies .............................72

Figure 52. Laurentian Basement Provinces ....................................................................................77

Figure 53. Detrital Zircon U-Pb Ages within the Range of Known Potential Source Terranes

Figure 54. Normalized Relative Probability Plot of this study and Park et al. (2010) ............82

Figure 55. Probability Density Plots of Igneous and Detrital U-Pb Age Distributions from

Africa and South America ..........................................................................................................83

Figure 56. QtFL and QmFLt Plots of the Norphlet Formation Samples ....................................87

Figure 57. Relative Abundances of Framework Grains of the Norphlet Formation from

Cross-section in Figure 58.......................................................................................................8

Figure 58. Location of Cross-section for Figure 57 .....................................................................8

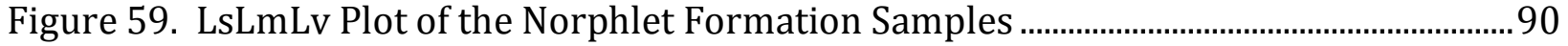

Figure 60. Abundances of Dense Minerals for all 10 Detrital Samples.........................................91

Figure 61. Geospatial Trends in Dense Mineral Abundances........................................................91

Figure 62. Provenance Scenario ..........................................................................................................93

Figure 63. Paleogeographic Reconstruction................................................................................96

Figure 64. Paleo-wind Patterns in North America in the Latest Jurassic ....................................97

Figure 65. Dune Migration Pattern from Vector Resultants of Dip Meter Data .........................97

\section{List of Tables}

Table 1. Samples Information for U-Pb Detrital Zircon Geochronology ......................................18

Table 2. Table of the Four Most Abundant U-Pb Age Populations ................................................42

Table 3. Comparison of Grenville-aged Zircon Between Park et al. (2010) and This Study.81

Table 4. Samples with Ambiguous U-Pb Ages and Potential Origins. 


\section{Introduction}

Currently, the Norphlet Formation is a very important reservoir in the eastern Gulf of Mexico (EGOM) in areas including the Florida Panhandle, southern Alabama, and central Mississippi as well as the offshore federal lease blocks Mobile Bay (MO), Destin Dome (DD), Mississippi Canyon (MC), and De Soto Canyon (DC; Fig. 1). The Jurassic Norphlet Formation first became a major drilling target in the onshore EGOM in 1968 when condensates were discovered in the Flomaton Field in Escambia County, Alabama. In 1979, gas was discovered in offshore Norphlet Formation reservoirs showing an increased potential of the reservoir with technological advances in offshore drilling and better understanding of the depositional environment (Mancini et al., 1985). Shell recently discovered 215 million BOE in the Mississippi Canyon offshore lease block in 7,257 ft (2,212 m) of water (Oil \& Gas Journal, 2012).

Other Jurassic formations have also proven to be important EGOM reservoirs including the Smackover and Haynesville formations. The Smackover Formation, an organic-rich carbonate unit conformably overlying the Norphlet Formation, likely sourced hydrocarbons both to itself and the Norphlet below (Claypool and Mancinl, 1989). The Haynesville Formation, which overlies the Smackover Formation, has an organic-rich shale unit that is thought to have sourced some of its overlying sandstone units and is a potential reservoir in areas of proper facies (DOI, 2008). 


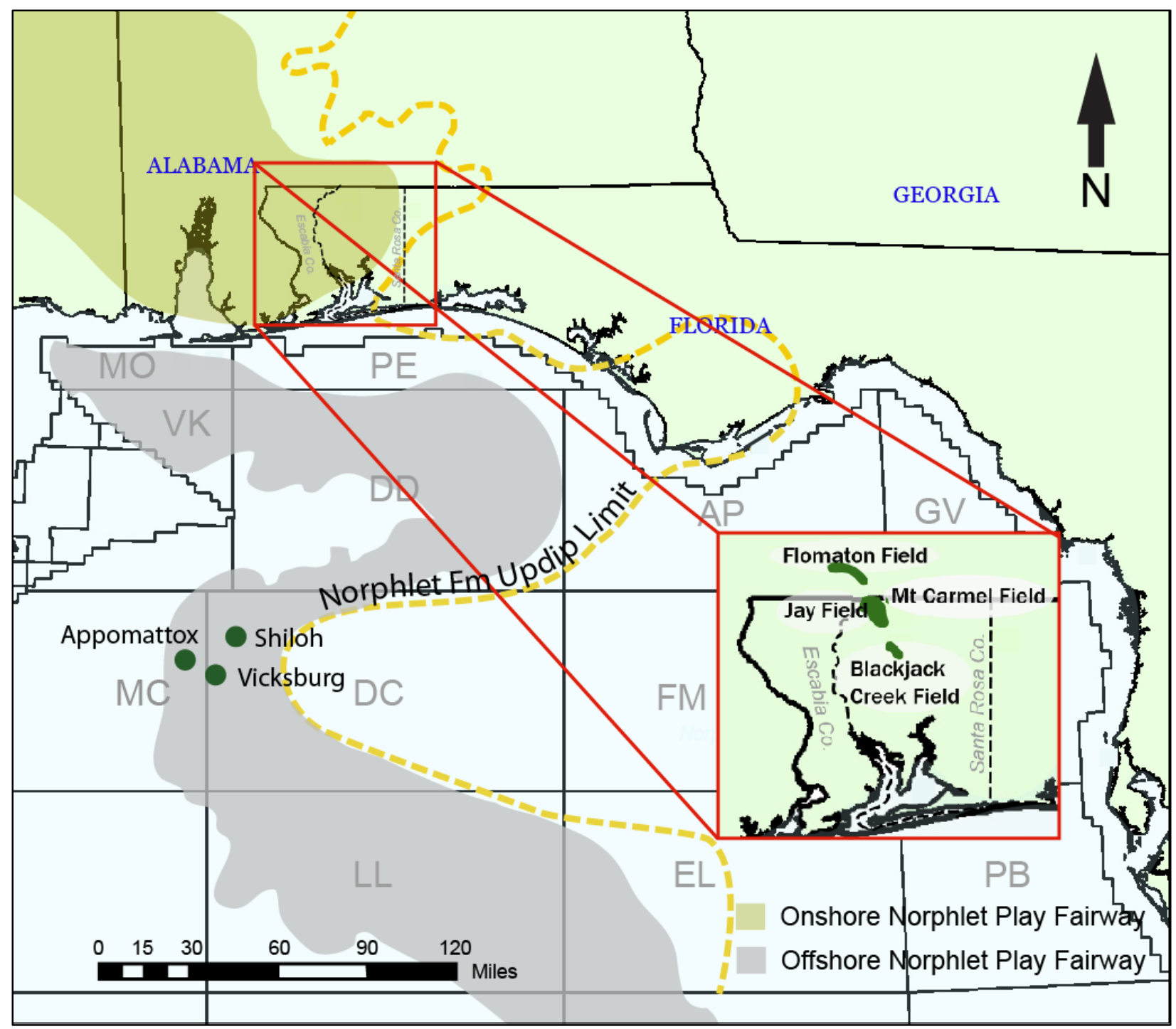

Figure 1. Major Norphlet producing fields in the Florida Panhandle highlighted in Green (Lloyd, 1991) including the Flomaton Field, just north of Florida, the first major Norphlet drilling target (Mancini et al., 1985). Gray area is the offshore Norphlet play fairway (BOEM, 2012a). Yellow region is the onshore Norphlet play fairway (Tew et al., 1991). Approximate location of the Shiloh, Vicksburg, and Appomattox prospects in the Mississippi Canyon and De Soto Canyon lease blocks marked by green circles. The Appomattox prospect contains at least 215 million BOE (Oil \& Gas Journal, 2012).

The Norphlet and Smackover formations have been heavily produced in Alabama and the Florida Panhandle. These formations in the Santa Rosa County of the Florida Panhandle currently produce from three fields: the Jay, Mt. Carmel, and Blackjack Creek fields. The Jay field is a major producing field in Florida, accounting for $83 \%$ of gas production and $60 \%$ of oil produced in Florida in 2008 (Fig. 1; DOI, 2008). The Norphlet also produces in the deep offshore 
Gulf of Mexico. As of 2001, all producing offshore wells deeper than 15,000 feet $(4,572 \mathrm{~m})$ were estimated to have 10 Tcf of recoverable gas, 2.5 Tcf of which is from the Norphlet Formation (MMS, 2001). The recent Shell discovery of 215 million BOE includes $150 \mathrm{ft}(45.7 \mathrm{~m})$ of oil pay in the Appomattox fault block structure in the Mississippi Canyon and De Soto Canyon lease blocks (Fig. 1; Oil \& Gas Journal, 2012).

\subsection{Research Problem and Significance}

Drilling of the Norphlet Formation in the central Gulf of Mexico began in 1979 and has continued and expanded in the Mobile Bay, DeSoto Canyon, and Mississippi Canyon offshore lease blocks. However, the EGOM is relatively unexplored and currently is under a drilling moratorium. The GOM Energy Security Act (2006) leasing and drilling moratorium covers most of the EGOM. While the Obama administration has allowed for drilling in the EGOM in the 2010-2015 leasing plan, it is still under the Energy Security Act moratorium until 2022 unless Congress decides to open the area. The Norphlet Formation within offshore Florida and the EGOM is a prospective target for future exploration upon expiration of the moratorium. A primary concern for exploration in this region is sparse well data, making reservoir distribution and quality difficult to predict. An improved paleogeographic model is needed to help understand reservoir distribution in this relatively unexplored area.

Previous paleogeographic models of the Norphlet deposystem in southwestern Alabama identified a northern Appalachian and Talladega slate belt source area (Fig. 2; Mancini et al., 1985; Walls, 1985). However, recent work has shown that the Gondwanan Suwannee terrane, which makes up the northern Florida basement, also sourced sand to the Norphlet Formation in southeastern Alabama and federal lease blocks offshore of the Florida Panhandle (Fig. 3; Lovell 
and Weislogel, 2010; Lovell, 2013) suggesting a more complex paleogeography and depositional pattern. Sediment lithology being a function of the source material from which it is derived and can vary significantly across source areas. Scott (1991) noted the difference between the Norphlet Formation framework grain abundances in the Florida Panhandle and those identified by Mancini et al. (1985) in southwestern Alabama (Figs. 4 and 9). The Norphlet Formation in southwestern Alabama is more compositionally mature, a difference that could be due to varying source lithology as well as distance from the source. These differences in provenance could also control reservoir quality. In order to create an improved paleogeographic model for

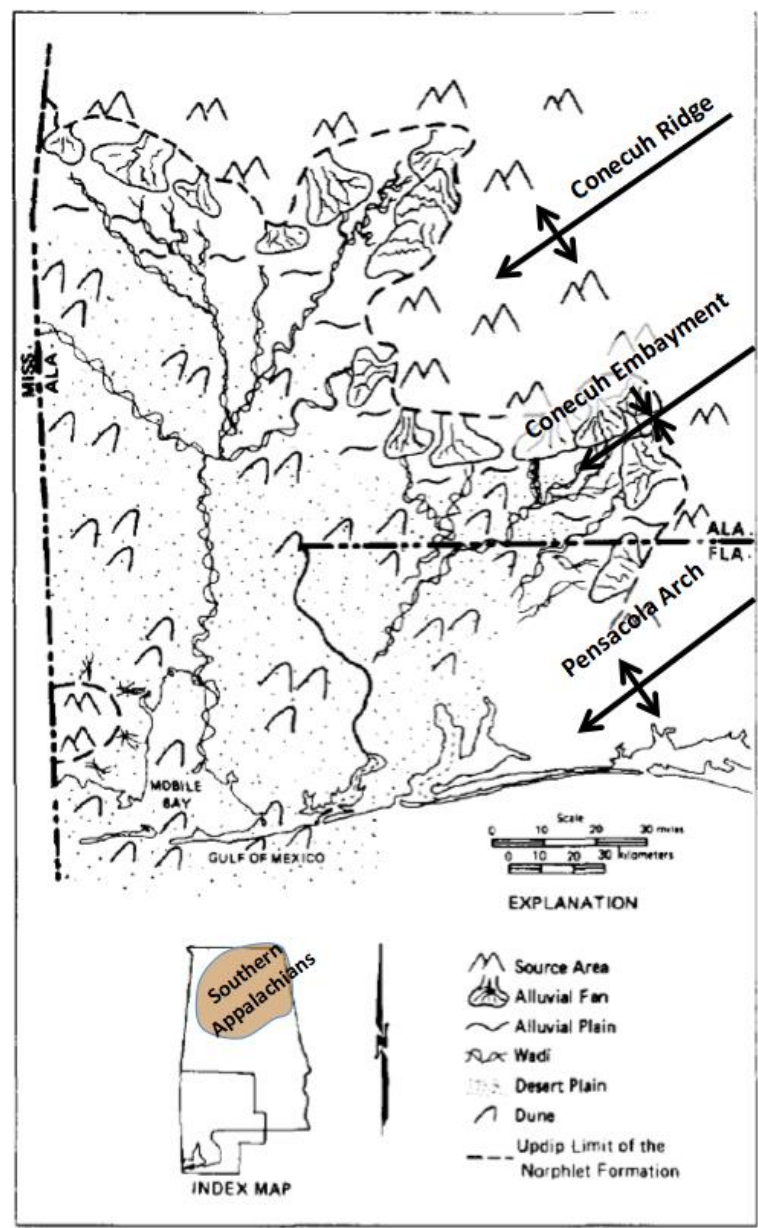

Figure 2. Paleogeographic model of the Norphlet Formation in southwest Alabama and the western Florida Panhandle (Modified from Mancini et al., 1985). the EGOM, the origin of the Norphlet and

surrounding sediments and dispersal patterns require additional constraints.

This study tests and expands upon previous paleogeographic models to aid in future exploration of the Norphlet Formation in the EGOM. Provenance scenarios determined from the U-Pb detrital zircon geochronology will help constrain sediment dispersal pathways and ultimately reservoir distribution, reservoir facies and reservoir quality in the EGOM. Knowing the source of sediments can help identify structural barriers and pathways for sediment dispersal that existed during the Late Jurassic. 


\subsection{Goals and Research}

This study focuses on the

Norphlet and surrounding

formations in the EGOM including

the Florida Panhandle, offshore

Florida Peninsula, and offshore

federal lease blocks Mobile Bay,

Pensacola, Destin Dome, Florida

Middle Ground, and St. Petersburg

(Fig. 3). In order to create an

improved paleogeographic model

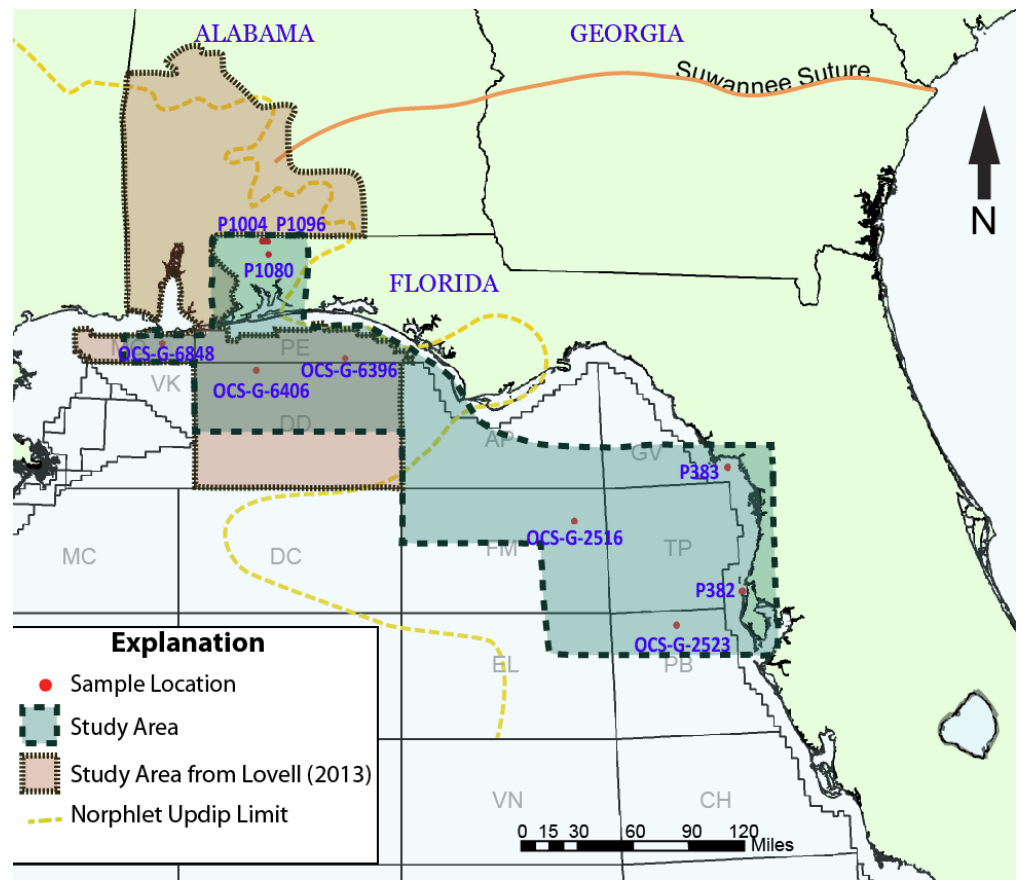

Figure 3. Study area highlighted in green. Lovell (2013) study area highlighted in brown.

for the EGOM, the origin of the

Norphlet and surrounding sediments will be

constrained using U-Pb detrital zircon

geochronology. U-Pb detrital zircon

geochronology is an excellent tool commonly

used for determining provenance due to the

robust nature of zircon. They are very resistant

to weathering, both mechanically and chemically

which allows for likely retention of all zircon

populations within a sediment package. They

also usually have high $\mathrm{U}$ and Th concentrations

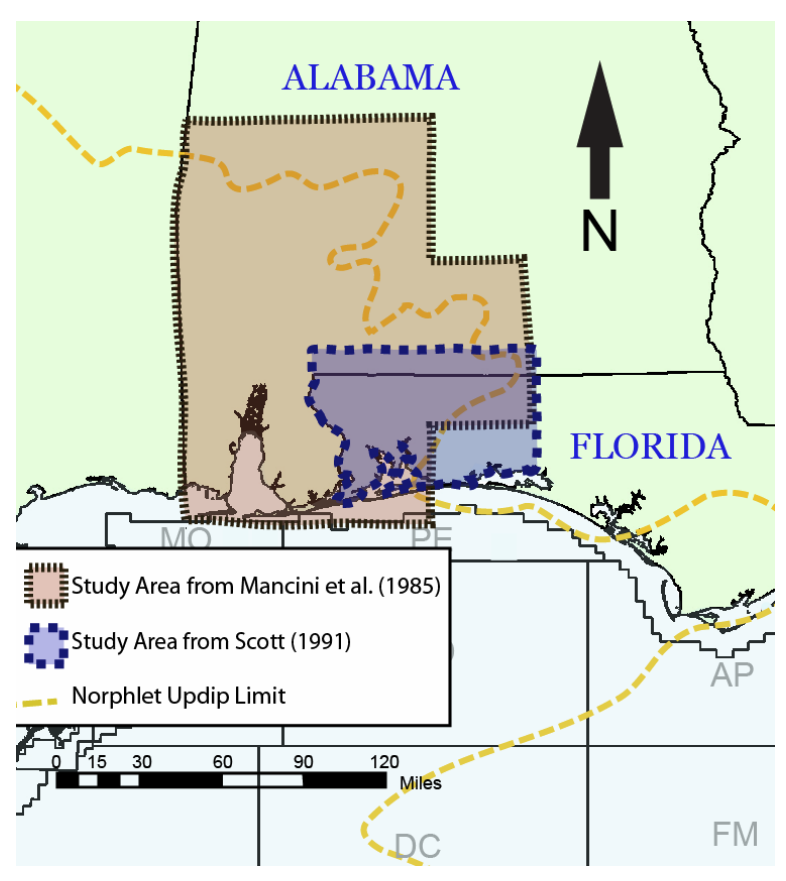

Figure 4. Study area of Norphlet Formation from Mancini et al. (1985) and Scott (1991). 
(10-100 ppm) with low common lead, are commonly found in felsic and intermediate rocks, and can retain lead up to the zircon's melting point at $\sim 1300^{\circ} \mathrm{C}$; therefore the $\mathrm{U}-\mathrm{Pb}$ isotopic system records crystallization age (Fedo et al., 2003; Hoskin and Schaltegger, 2003).

Provenance, determined from U-Pb detrital zircon ages, is supplemented by thinsection petrography and dense mineral analysis. Thin-section petrography is another useful tool for determining provenance. Dickinson and Suczek (1979) have shown that the relationship between sandstone composition and plate tectonics can be used to assess the origin and potential source terranes of a sandstone through the quantitative evaluation of framework modal abundances. Along with a qualitative assessment of dense mineral abundances, U-Pb detrital zircon geochronology and thin-section petrology will provide a robust method for constraining the source terranes for the Norphlet and surrounding formations. The provenance work as well as large-scale distributional trends identified through well log analysis and previous studies regarding Norphlet distribution will be used to generate paleogeographic models.

\section{Background}

\subsection{Tectonic Setting}

The deposition of Jurassic sediments in the Gulf of Mexico basin were predominantly controlled by rifting that accompanied the breakup of the supercontinent Pangea (Salvador, 1987; Dobson and Buffler, 1997). Rifting began during the Late Triassic about 204 Ma until the late Callovian at $160 \mathrm{Ma}$ (Marton and Buffler, 1999) due to mantle upwelling which possibly created thinned transitional crust (Fig. 5; Salvador, 1987). The NW-SE trending rifts lead to the development of alternating paleo-highs, consisting of thicker transitional crust of $20-35 \mathrm{~km}$, and 
paleo-lows produced from

thinner transitional crust

about 8-15 km thick (Dobson

and Buffler, 1997). The paleo-

highs and lows were

regionally extensive, up to 240

$\mathrm{km}$ long and creating up to 2

km of offset (Wilson, 2011).

Prominent paleo-highs in the

study area include the

Wiggins Arch, Pensacola Arch,

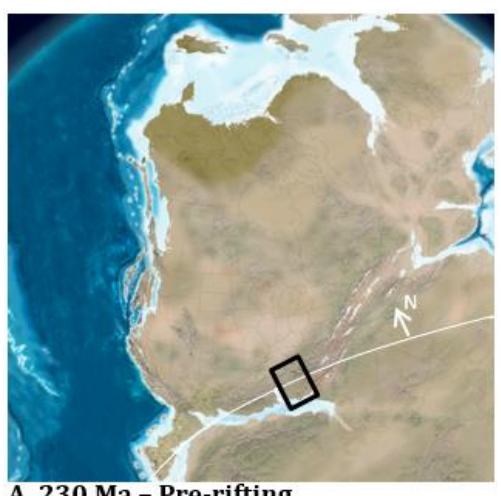

A. $230 \mathrm{Ma}$ - Pre-rifting

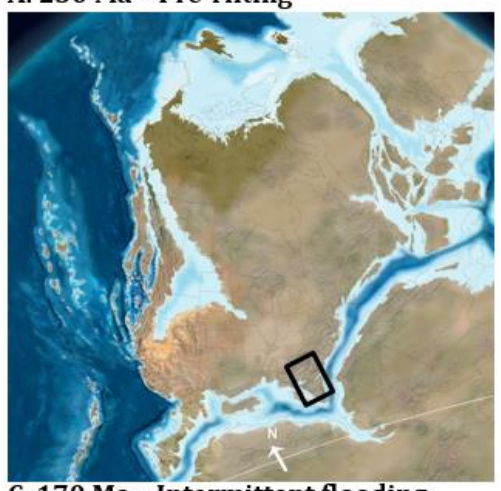

C. $170 \mathrm{Ma}$ - Intermittent flooding within the study area

D. $150 \mathrm{Ma}$ - Complete separation

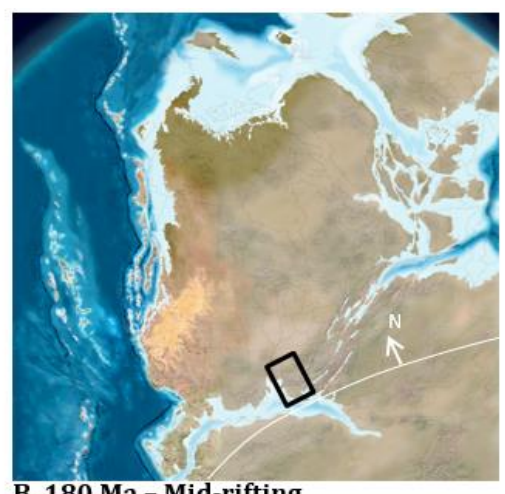

B. 180 Ma - Mid-rifting

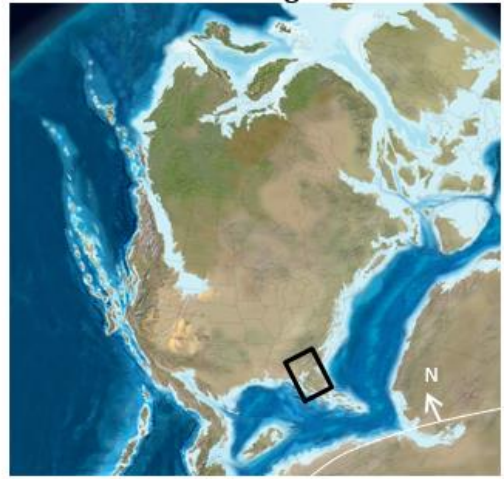

Figure 5. Paleogeographic maps. A) Middle Triassic, B) Early Jurassic, C) Middle Jurassic, and D) Late Jurassic. (Modified from Blakey, 2011 $<$ jan.ucc.nau.edu/ rcb7/nam.html >). Equator and north arrow in A., B., and D inferred from Parrish and Peterson (1988).

Ground Arch, and the Sarasota Arch and paleo-lows include the Mississippi Interior Salt Basin,

Apalachicola Embayment, DeSoto Canyon Salt Basin, Tampa Embayment, and the South Florida

Basin. Figure 6 illustrates these highs and lows created in the basement rock as well as

locations where volcanism was occurring during the Triassic and Jurassic. The rhyolitic and

basaltic volcanism in Georgia (Chowns and Williams, 1983) and basaltic volcanism (basalt,

diabase, and diacitic tuff) in the Florida Panhandle are thought to be rift-related occurring along

the Triassic Tallahassee graben, which coincides with the Apalachicola Embayment (Arthur,

1988; Heatherington and Mueller, 2003). However, basalt flows and rhyolites in southern

Florida have been related to a hot spot below due to their difference in geochemistry

(Heatherington and Mueller, 2003). 


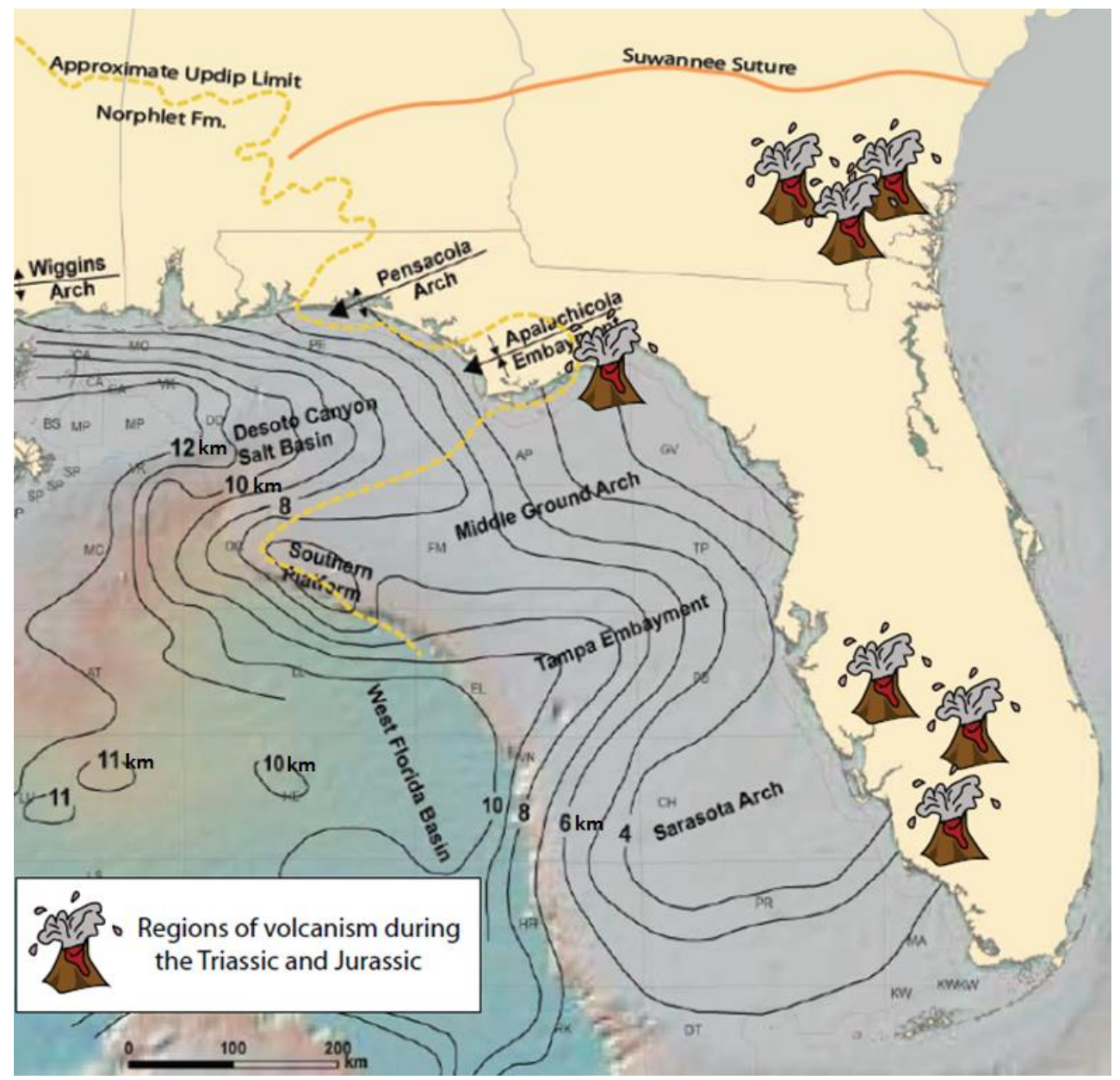

Figure 6. Paleo-highs and lows in the eastern Gulf of Mexico (modified from Wilson, 2011). Contours are depth to the basement in $2 \mathrm{~km}$ intervals. Approximate updip limit of the Norphlet Formation from Mancini et al. (1990) and Hunt (2012), and Suwannee Suture from Steltenpohl et al. (2008). Volcanism from Arthur (1988); Chowns and Williams (1983); and Heatherington and Mueller (2003).

By the late Jurassic (Oxfordian), extension had waned leading to a period of tectonic stability and thermal subsidence. This caused development of deposits that were more widespread and uniform which was quite different from the lower and mid dle Jurassic sediments which accumulated in the paleolows and onlapped onto rift grabens and halfgrabens (Salvador, 1987). 


\subsection{Depositional Environment and Stratigraphy}

The Upper Triassic syn-rift sediments are terrestrial red bed sandstones and volcanics of the Eagle Mills Formation. The sediments of the Eagle Mills Formation were derived from the horst blocks and were deposited at the same time basalt dikes and sills were forming in the southeastern US from the rifting events (Salvador, 1987; Tew et al., 1991). This formation contains the oldest Mesozoic strata and is preserved in the paleo-lows (Fig. 7). However, very few wells penetrate this formation and it is only known from a few locations. From paleontological data (BOEM, 2012), only one EGOM well located in the Gainesville lease block identifies this formation. Presence of it in the western Florida Panhandle has been inferred in

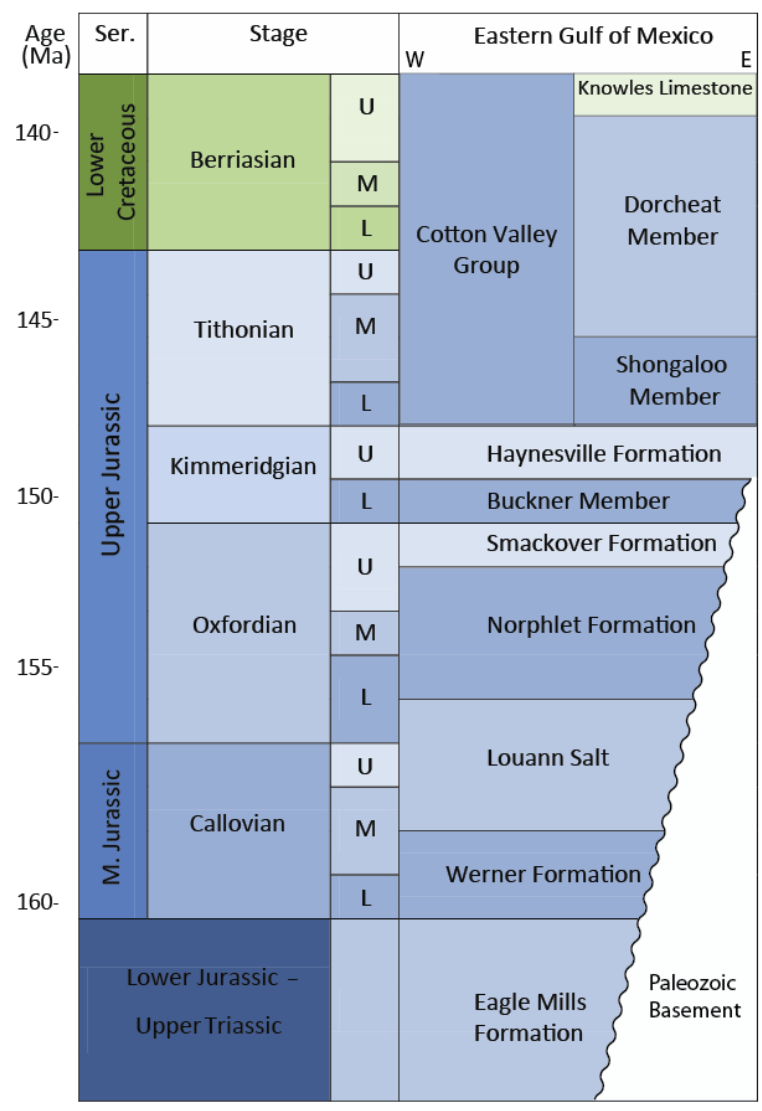

Figure 7. Generalized stratigraphic column of the Eastern Gulf of Mexico. Modified from Mancini et al., 2008 and Mancini et al., 1985. previous studies (Scott, 1991).

Intermittent flooding of marine waters into the eastern Gulf of Mexico began during late Bathonian and Callovian from a small opening to the Pacific to the southwest of the study area (Salvador, 1987; Dobson and Buffler, 1997; Ajdukiewicz et al., 2010). During the Middle Jurassic, an arid climate prevailed which led to the evaporative concentration of hypersaline marine water resulting in widespread deposition of the Callovian Werner Formation and the Callovian to earliest Oxfordian Louann Salt in the topographic lows (Mancini et al., 1985). The minor amount of shale that occurs at the base of the 
Werner Formation represents the initial transgression of normal marine water into the Gulf of Mexico. However, most of the Werner Formation consists of the overlying anhydrite. This formation is discontinuously distributed and was preferentially deposited in the loci of subsiding grabens (Tew et al., 1991). The distribution of the Louann Salt was also primarily controlled by paleotopography as well as the regional peripheral fault system which rims the northern Gulf of Mexico continental rift margin and roughly controlled the updip limit of thick Louann Salt deposits (Tew et al., 1991). The thickest onshore accumulations in the EGOM occur in the Mississippi Interior Salt Basin. The Louann Salt is absent from Chocotaw, Conecuh, and Pensacola-Decator ridges (Tew et al., 1991). A basinward increase in salt thickness occurs offshore where as much as 2,000 feet $(610 \mathrm{~m})$ of salt may have accumulated. On the western Florida shelf the Louann Salt began during the Oxfordian, syn- and post-Norphlet deposition (determined through seismic data), and is continuing through the present creating several important hydrocarbon-capturing structures such as diapirs and domes (Dobson and Buffler, 1997).

With continued arid conditions, alluvial, fluvial, and eolian sands of the Norphlet Formation were deposited conformably on top of the Louann Salt or unconformably above the Werner, Eagle Mills, or basement depending on the updip limit of these formations. A broad desert existed in southwestern Alabama and western Florida that was rimmed to the north and east by the Appalachians and to the south by a developing shallow Oxfordian Sea (Mancini et al., 1985; Dobson and Buffler, 1997). The paleo-highs likely acted as the source areas for sediment deposited in the adjacent lows, sourcing the proximal deposition of the alluvial conglomerate facies (Fig. 2). Downdip, the conglomerates grade into red bed sandstones and 
intermittent wadi complexes, which then transition into eolian desert plain sediments (Mancini et al., 1985). The wadi complexes, which most frequently occur adjacent to the conglomerate facies, were responsible for moving sediment from the paleo-highs into the eolian system where the sediments were reworked into dunes (Hunt, 2012).

The Norphlet Formation in the eastern Gulf of Mexico can be up to $450 \mathrm{~m}$ thick (Salvador, 1987) and is made up of four major facies (Pearson, 2011). The lower Norphlet is a discontinuous black shale deposited in a bay/lagoonal setting. The conglomeritic sandstone facies represents a wadi and proximal alluvial fan setting with poorly-sorted clasts that are composed of phyllite, chert, quartzite, granite and rhyolite rock fragments. Red bed sandstone facies of the Norphlet Formation represent more distal alluvial fan deposition as well as wadi and fluvial environments. This facies consists predominately subarkose sandstones, siltstones, and mudstones. The eolian sandstone facies, known as the Denkman Member, can be greater than $180 \mathrm{~m}$ thick in onshore Alabama and can range from lithic arkose to mature, well-sorted quartz arenites depending on location (Mancini et al., 1985; Scott, 1991; Pearson, 2011).

In the late Oxfordian, the Gulf of Mexico opened up to the Atlantic, flooding the Norphlet (Mancini et al., 1990; Ajdukiewicz et al., 2010). Due to the transgression of the Oxfordian Sea, the upper Norphlet is composed of marine facies with finer clastics and more carbonate and/or quartz cement (Mancini et al., 1985). The transgression is thought to have been low energy and fairly rapid due to the lack of large-scale reworking of the upper Norphlet (Ajdukiewicz et al., 2010), high preservation of fossils, and lack of bioturbation (Mancini et al., 1985). 
The Smackover carbonates were deposited above the Norphlet in the Oxfordian Sea (Mancini et al., 1990; Ajdukiewicz et al., 2010) and consist of three distinct facies. The lower Smackover was deposited in an anoxic, low energy, marine environment and is an excellent hydrocarbon source rock (Pearson, 2011). While the mean TOC of the entire lower Smackover is only $0.5 \%$, isolated stylolites can have up to $10 \%$ TOC (Sassen et al., 1987). The lower Smackover is interpreted to be intertidal to subtidal and consists of laminated lime mudstone. Above this is a subtidal argillaceous limestone that shows burrows indicating more oxic conditions. The upper part of the Smackover Formation was deposited in a high-energy intertidal to subtidal environment and consists of oolitic and peloidal grainstone and packstone (Mancini et al., 1990; Pearson, 2011).

During the Kimmeridgian, sabkha and saline lagoon environments lead to the deposition of the Haynesville Formation (Salvador, 1987; Mancini et al., 1990). The lowest unit of the Haynesville Formation is the Buckner Anhydrite Member, consisting primarily of massive anhydrite. The middle unit of the Haynesville Formation consists of sandstone, shale, and anhydrite and is overlain by a lithologically similar upper unit that also includes lime mudstone. This formation has been interpreted to illustrate upward shallowing from subaqueous to subaerial terrestrial deposits (Mancini et al., 1990). In the eastern Gulf of Mexico, the Haynesville Formation consists of updip conglomerate and sandstone which grades into to sandstone and shale downdip (Dobson and Buffler, 1997).

\subsection{Norphlet Formation Petrology}

Most of the Florida Panhandle sits between the Conecuh Ridge and Pensacola Arch within the Conecuh Embayment. The Norphlet Formation in the Florida Panhandle is thought 
to be sourced from both of these paleo-highs (Fig. 2). Scott (1991) studied the sandstone petrology of the upper Norphlet, Denkman Member in several counties in the Florida Panhandle, his results summarized below.

In the Florida Panhandle, the Denkman Member is a lithic arkose (e.g., Folk, 1980). The average framework grain modal composition consists of $61 \%$ quartz ( $90 \%$ monocrystalline), $26 \%$ feldspar, and $12 \%$ rock fragments. Lithic fragment modal abundances are $80 \%$ metamorphic, $15 \%$ volcanic, and $5 \%$ sedimentary rock fragments (Scott, 1991). The most common rock fragment is a finely crystalline grain type which bears resemblance to chert but is

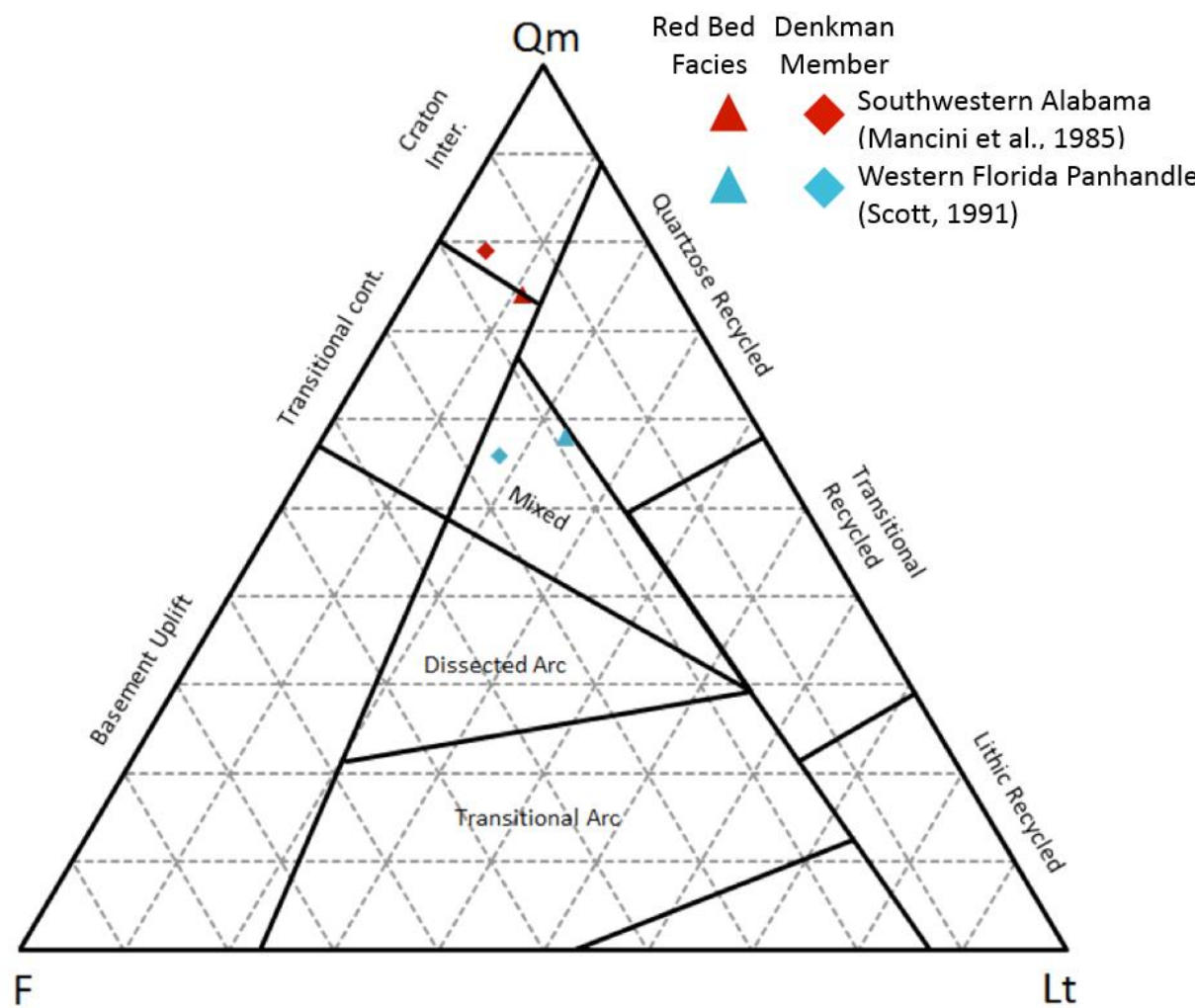

Figure 8. QmFLt plot of the average framework grain modal composition of the Norphlet Formation in southwestern Alabama (Red; Mancini et al., 1985) and the western Florida Panhandle (Blue; Scott, 1991). Triangles represent the red bed facies and the diamonds represent the Denkman Member. classified as a

metamorphic rock fragment due to occasional phyllosilicate inclusions and microlayers of some grains (Scott, 1991).

This varies somewhat from what is seen in southwestern Alabama, where the framework grains of the Denkman Member is on average composed of $79 \%$ quartz, $16 \%$ feldspar, and $5 \%$ rock fragments. The rock fragment types include chert, slate, phyllite, schist, 
and quartzite (Mancini et al., 1985). The Florida Panhandle has a much higher percentage of rock fragments and less quartz than southwestern Alabama.

Below the Denkman Member is the red sandstone and mudstone lithofacies. In the Florida Panhandle, the red bed sandstone composition is feldspathic litharenite with the average framework grains consisting of $61 \%$ quartz ( $92 \%$ monocrystalline), $15 \%$ feldspar, and $23 \%$ rock fragments. Lithic grain variety abundance is $74 \%$ metamorphic and $24 \%$ volcanic rock fragments (Scott, 1991). In southwestern Alabama, the average framework grain composition of the red bed sandstone is $74 \%$ quartz, $14 \%$ feldspar, and $11 \%$ rock fragment. Rock fragment types in the southwestern Alabama red bed sandstone include chert, phyllite, quartzite, schist, and basic to felsic igneous rock (Mancini et al., 1985).

Toward the updip limit of the Norphlet Formation the conglomeritic lithofacies is present. The conglomeritic lithofacies in the Florida Panhandle consists of pebble to cobblesized, angular to rounded clasts of plutonic and metamorphic rocks (Scott, 1991). In southwestern Alabama the conglomeritic lithofacies consist of granule- to cobble-size, angular to subangular, fragments of chert, shale, quartzite, granite, and rhyolite (Mancini et al., 1985). These variations in lithofacies from southwestern Alabama and the Florida Panhandle (Fig. 8) are likely caused by their proximity to the paleo-high source as well as the type of source material. Figure 6 shows a proposed suture zone between the Laurentian crust and the Gondwanan, Suwannee Terrane. The approximate location of the suture suggests that the Conecuh Ridge basement likely consists of both Laurentian and Suwannee terrane while the Pensacola Arch is underlain solely by the Gondwanan-Suwannee Terrane. 


\section{Methodology}

\subsection{Sampling}

A total of ten detrital zircon samples, six from the Norphlet Formation (samples P1004, P1096, P1080, OCS-G-6848, OCS-G-6406, and OCS-G-6396), one from the Haynesville Formation and Paleozoic basement (OCS-G-2513), one from each of the Cotton Valley Group, Haynesville Formation and Paleozoic basement (OCS-G-2523), and two from the Paleozoic basement (P383 and P382), came from 10 different well locations from onshore Florida and the offshore lease blocks Mobile Bay, Destin Dome, Pensacola, Florida Middle Ground, and St. Petersburg (Fig. 9). Florida samples were provided by the Florida Geological Survey and chosen based on location, depth, and availability. Identification of the sampled formations came from physical observation of sample lithology as well as from well log data, paleontological data from BOEM (2012b), and previous studies.

Sandstone samples from 3 onshore and 2 offshore Florida State wells were taken from the Norphlet or surrounding formations. Onshore samples P1080, P1004, and P1096 were taken from core chips directly from the Norphlet Formation sampling each foot available, accumulating 150-200 grams for each sample. Because wells P382 and P383 are east of the updip limit of the Norphlet Formation, the Paleozoic basement was sampled. Well P382 was sampled for all available core chips over 11 feet of basement resulting in $\sim 400$ grams of sample. Well P383 had core chips available for 13 feet of basement which were sampled and supplemented with cuttings from above ( $\sim 300$ grams of sample). Table 1 summarizes the pertinent information regarding samples used in this study. 


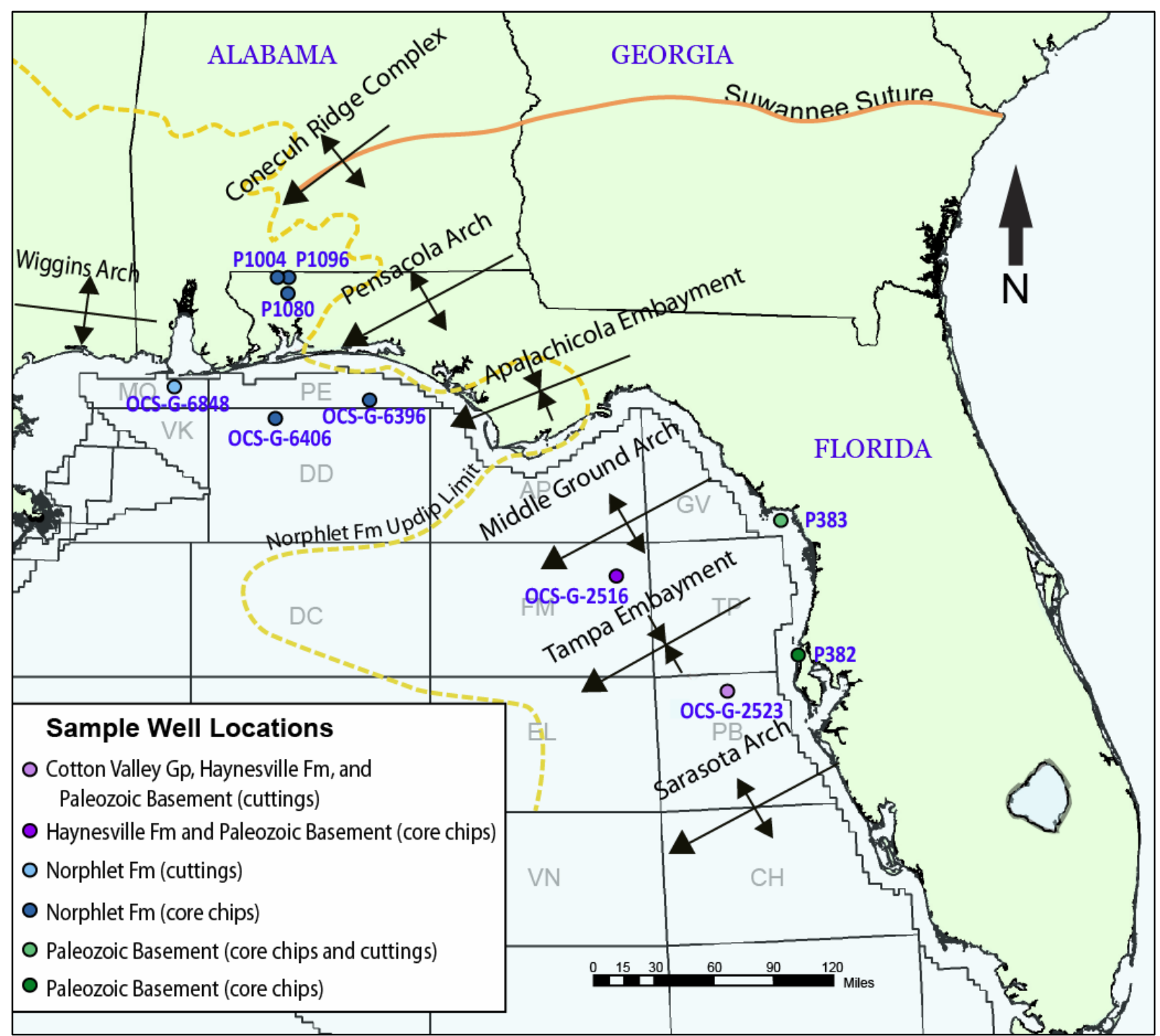

Figure 9. Location of samples used for U-Pb detrital zircon geochronology. Arrows indicate structural highs and lows created from the rifting of Pangea. Suwannee suture from Steltenpohl et al. (2008). Norphlet updip limit from Mancini et al. (1990).

The Oklahoma Geological Survey provided four offshore samples from the Mobile Bay, Pensacola, Florida Middle Ground, and St. Petersburg federal lease blocks. Eighteen nonconsecutive feet of core was available for the Pensacola well (OCS-G-6396) in which each foot was sampled, accumulating 2 kilograms of sample. The remaining wells did not have available core and thus cuttings were utilized. The Mobile Bay well (OCS-G-6848) contained an apparent Norphlet interval identified for sampling. Identification of Norphlet in this well was based on 
the sandstone lithology immediately following a thick limestone section as well as from mud log descriptions. Two grams of cuttings were sampled from every ten feet for 50 feet ( 100 grams of sample). The Florida Middle Ground and St. Petersburg wells are east of the Norphlet updip limit. In this case, clastics within and above the Paleozoic basement were sampled and identified based on BOEM paleontological data (2012) and seismic observations of Dobson and Buffler (1997). The Florida Middle Ground well (OSC-G-2516) was sampled for the Haynesville Formation and Paleozoic basement with 2 grams sampled every ten feet ( 200 grams of sample). The St. Petersburg well (OSC-G-2523) was sampled for the Cotton Valley Group, Haynesville Formation and Paleozoic basement with 2 grams sampled every ten feet ( 300 grams of sample). Lastly, Murphy Oil Corporation supplied core plugs from a well within the Destin Dome lease block (OCS-G-6406). Core plugs were sampled every three feet for 180 feet ( 1.2 kg of sample). 
Table 1. Information for samples used for U-Pb detrital zircon geochronology.

\begin{tabular}{|c|c|c|c|c|c|c|c|c|c|c|c|}
\hline $\begin{array}{l}\text { Sample } \\
\text { name }\end{array}$ & API & $\begin{array}{l}\text { Location } \\
\text { Lease block }\end{array}$ & $\begin{array}{l}\text { Latitude/ } \\
\text { Longitude }\end{array}$ & Origin of sample: & Sample Formation & $\begin{array}{l}\text { Sample type } \\
\text { (cuttings/core) }\end{array}$ & $\begin{array}{l}\text { Approx. } \\
\text { Sample Size } \\
\text { (grams) }\end{array}$ & $\begin{array}{l}\text { Lithology/ } \\
\text { Composition }\end{array}$ & Depth & $\begin{array}{l}\text { Operator of } \\
\text { well }\end{array}$ & Production \\
\hline P1004 & 0911320188 & $\begin{array}{l}\text { Santa Rosa } \\
\text { County, FL }\end{array}$ & $\begin{array}{l}30^{\circ} 57^{\prime} 34^{\prime \prime} \mathrm{N} \\
87^{\circ} 9^{\prime} 21.92^{\prime \prime} \mathrm{W}\end{array}$ & $\begin{array}{l}\text { Florida Geological } \\
\text { Survey }\end{array}$ & Norphlet Formation & Core Chips & 150 & Sandstone & $15,765-15,787$ & Exxon & $\begin{array}{l}1981 \\
\text { Test Gas: } 1358 \text { MCFPD } \\
\text { Test Oil: } 1104 \text { BOPD }\end{array}$ \\
\hline P1096 & 0911320207 & $\begin{array}{l}\text { Santa Rosa } \\
\text { County, FL }\end{array}$ & $\begin{array}{l}30^{\circ} 57^{\prime} 15.48^{\prime \prime} \mathrm{N} \\
87^{\circ} 6^{\prime} 32^{\prime \prime} \mathrm{W}\end{array}$ & $\begin{array}{l}\text { Florida Geological } \\
\text { Survey }\end{array}$ & Norphlet Formation & Core Chips & 200 & Sandstone & $15,160-15,239$ & Smackco Ltd & Dry Hole \\
\hline P1080 & 0911320203 & $\begin{array}{l}\text { Santa Rosa } \\
\text { County, FL }\end{array}$ & $\begin{array}{l}30^{\circ} 51^{\prime} 13^{\prime \prime} \mathrm{N} \\
87^{\circ} 6^{\prime} 12^{\prime \prime} \mathrm{W}\end{array}$ & $\begin{array}{l}\text { Florida Geological } \\
\text { Survey }\end{array}$ & Norphlet Formation & Core Chips & 200 & Sandstone & $16,099-16,153$ & Exxon & $\begin{array}{l}1982 \\
\text { Test Gas: } 302 \text { MCFPD } \\
\text { Test Oil: } 984 \text { BOPD }\end{array}$ \\
\hline OCS-G-6848 & 60815400990000 & Mobile Bay & $\begin{array}{l}30^{\circ} 8^{\prime} 21.7^{\prime \prime} \mathrm{N} \\
88^{\circ} 4^{\prime} 43.68^{\prime \prime} \mathrm{W}\end{array}$ & $\begin{array}{l}\text { Oklahoma Geological } \\
\text { Survey }\end{array}$ & Norphlet Formation & Cuttings & 100 & Sandstone & $20,090-22,140$ & $\begin{array}{l}\text { Mobile Oil E\&P } \\
\text { Southeast }\end{array}$ & Gas show \\
\hline OCS-G-6406 & 60822400357000 & Destin Dome & $\begin{array}{l}29^{\circ} 56^{\prime} 16.21^{\prime \prime} \mathrm{N} \\
87^{\circ} 11^{\prime} 9.86^{\prime \prime} \mathrm{W}\end{array}$ & $\begin{array}{l}\text { Murphy Oil } \\
\text { Corporation }\end{array}$ & Norphlet Formation & Core Chips & 1,200 & Sandstone & $22,560-22,740$ & $\begin{array}{l}\text { Murphy E\&P } \\
\text { Company }\end{array}$ & Gas show \\
\hline OCS-G-6396 & 60821400030000 & Pensacola & $\begin{array}{l}30^{\circ} 1^{\prime} 10.62^{\prime \prime} \mathrm{N} \\
86^{\circ} 23^{\prime \prime} 45.57^{\prime \prime} \mathrm{W}\end{array}$ & $\begin{array}{l}\text { Oklahoma Geological } \\
\text { Survey }\end{array}$ & Norphlet Formation & Core & 2,000 & Sandstone & $\begin{array}{l}17,501-17,504 \\
17,528-17,532 \\
17,558-17,567 \\
17,584-17,587\end{array}$ & Texaco & Dry Hole \\
\hline OCS-G-2516 & 60828400000000 & $\begin{array}{l}\text { Florida } \\
\text { Middle } \\
\text { Ground }\end{array}$ & $\begin{array}{l}28^{\circ} 41^{\prime} 44.12^{\prime \prime} \mathrm{N} \\
84^{\circ} 19^{\prime} 50.16^{\prime \prime} \mathrm{W}\end{array}$ & $\begin{array}{l}\text { Oklahoma Geological } \\
\text { Survey }\end{array}$ & $\begin{array}{l}\text { Haynesville Formation } \\
\text { and Paleozoic Basement }\end{array}$ & Cuttings & 200 & Sandstone/Shale & $14,713-15,658$ & Texaco & Dry Hole \\
\hline OCS-G-2523 & 60835400010000 & $\begin{array}{l}\text { Saint } \\
\text { Petersburg }\end{array}$ & $\begin{array}{l}27^{\circ} 50^{\prime} 32.23^{\prime \prime} \mathrm{N} \\
83^{\circ} 25^{\prime} 48.66^{\prime \prime} \mathrm{W}\end{array}$ & $\begin{array}{l}\text { Oklahoma Geological } \\
\text { Survey }\end{array}$ & $\begin{array}{l}\text { Cotton Valley Group, } \\
\text { Haynesville Formation, } \\
\text { and Paleozoic Basement }\end{array}$ & Cuttings & 300 & Sandstone/Shale & $15,810-16,900$ & Texaco & Dry Hole \\
\hline P382 & 0921720001 & $\begin{array}{l}\text { Citrus } \\
\text { County, FL }\end{array}$ & $\begin{array}{l}28^{\circ} 5^{\prime} 59^{\prime \prime} \mathrm{N} \\
82^{\circ} 49^{\prime} 41^{\prime \prime} \mathrm{W}\end{array}$ & $\begin{array}{l}\text { Florida Geological } \\
\text { Survey }\end{array}$ & Paleozoic Basement & Core Chips & 400 & $\begin{array}{l}\text { Shale } \\
\text { Siltstone } \\
\text { Quartzite }\end{array}$ & $\begin{array}{l}6,035-6,044 \\
6045 \\
6046\end{array}$ & Mobil Oil Corp & Dry Hole \\
\hline P383 & 0927520002 & $\begin{array}{l}\text { Levy County, } \\
\text { FL }\end{array}$ & $\begin{array}{l}29^{\circ} 5^{\prime} 24^{\prime \prime} \mathrm{N} \\
82^{\circ} 55^{\prime} 16^{\prime \prime} \mathrm{W}\end{array}$ & $\begin{array}{l}\text { Florida Geological } \\
\text { Survey }\end{array}$ & Paleozoic Basement & $\begin{array}{l}\text { Core Chips } \\
\text { Cuttings }\end{array}$ & 300 & Chips-Quartzite & $\begin{array}{l}\text { Chips: } 4722-4735 \\
\text { Cuttings: } 4500-4720\end{array}$ & Mobil Oil Corp & Dry Hole \\
\hline
\end{tabular}




\subsection{U-Pb detrital zircon geochronology}

Separation of zircon grains from the samples involved crushing, milling, hydrodynamic separation using a Gemini table, magnetic separation using a Frantz magnetic separator, dense liquid separation using lithium polytungstate (LPT) and methylene iodide (MEI), and nitric acid to remove pyrite. Most of the samples were small, ranging from 100 to 500 grams, with the exception of the larger Pensacola and Destin Dome samples; these two wells were the only samples run through the Gemini table before magnetic and liquid separation.

After the samples were soaked in $20 \%$ nitric acid to dissolve pyrite, they remained fairly impure ranging from only $20-50 \%$ zircon. To concentrate the zircons without bias to size or shape, other grains (predominately barite) were mostly removed by hand picking with tweezers. The zircons were then mounted in epoxy disks of an inch in diameter, polished, and imaged. Cathodoluminescence $(C L)$ imaging was done at WVU using a JEOL scanning electron microscope. Both backscatter and $\mathrm{CL}$ detectors were used to attain SEM and $\mathrm{CL}$ images of the mounts. The mounts were also imaged using a Nikon Eclipse polarizing microscope.

Ultimately, over 100 zircons were concentrated for each sample. Vermeesch (2004) recommends 117 grains be dated to achieve a 95\% certainty that no populations are missing. While several hundred grains would be necessary to represent all age populations, Andersen (2005) recommends practical work to require 35-70 grains in order to achieve a detection limit of $1-2 \%$ at a 0.5 probability (where populations less than $1-2 \%$ in abundance may fail to be detected $50 \%$ of the time). However, with the range of $35-70$ grains, a $10 \%$ population abundance has a probability of 0.95 and will fail detection less than $5 \%$ of the time. For this 
study, a target of 100 grains per mount were analyzed giving a detection limit of $>1 \%$ at a 0.5 probability and a detection limit of $\sim 3 \%$ at a probability of 0.95 .

Samples were analyzed at the Arizona LaserChron Center (ALC) at the University of Arizona using Laser Ablation-Multicollector (ICP-MS). The GVI Isoprobe uses a $193 \mathrm{~nm}$ wavelength laser to produce stable elemental analysis. The detrital zircon analysis used a beam diameter of 30 microns and a pit depth of approximately 15 microns (Gehrels et al., 2006). Samples are analyzed using comparison to a standard zircon. The in-house standard used at the ALC is a Sri Lanka zircon that dates $563.5+/-2.3$ Ma. R-33 was used as a secondary standard, which has an age 419.3+/- 0.4 Ma. Each sample began with five standard analyses. Then a standard was analyzed every five grains until 100 hundred of the sample grains were analyzed. At the end, three Sri Lanka standards and one R-33 standard were analyzed. The ratios of ${ }^{206} \mathrm{~Pb} /{ }^{238} \mathrm{U},{ }^{207} \mathrm{~Pb} /{ }^{235} \mathrm{U}$, and ${ }^{206} \mathrm{~Pb} /{ }^{207} \mathrm{~Pb}$ were obtained in order to determine the zircon age with an error of 2-sigma.

Data was extracted and reduced using the Isoplot 4 software (Ludwig, 2012). All samples had some removal of grain analyses based on several factors including poor precision due to high errors ( $>10 \%$ uncertainty) of the ${ }^{206} \mathrm{~Pb} /{ }^{207} \mathrm{~Pb}$ and ${ }^{206} \mathrm{~Pb} /{ }^{238} \mathrm{U}$ isotope ratios, high ${ }^{204} \mathrm{~Pb}$, low ${ }^{206} \mathrm{~Pb} /{ }^{204} \mathrm{~Pb}$, high discordance $(>20 \%)$, or reverse discordance $(>5 \%)$. Isoplot 4 was then used to create various plots of the data.

Age and U/Th cross-plots were made in order to identify metamorphic detrital zircon populations within each sample. The U/Th ratio of metamorphic zircons is generally much higher than igneous zircons due to the larger ionic radius of $\mathrm{Th}^{4+}$ than $\mathrm{U}^{4+}$ and is thus preferentially purged during metamorphism. The $\mathrm{U} / \mathrm{Th}$ ratio of igneous zircons is typically less 
than 2 but more rarely can reach up to 5 or greater (Hoskin and Schaltegger, 2003). Because of this, a cut off of 4 is used to distinguish metamorphic zircons.

\subsection{Thin-section Petrography}

Thin-section petrography was used in this study to supplement the U-Pb detrital zircon data as a provenance indicator. Eleven thin-sections were point counted from five wells, one of which had conventional core and four of which had sets of sidewall core chips, within the eolian facies of the Norphlet Formation. The Gazzi-Dickinson method of point counting was used in order to avoid grain size biases such as those based on breakage of lithic grains. Where other methods would classify a granite lithic clast in the lithic mode, the Gazzi-Dickinson method classifies it by the individual sand-sized mineral components such as quartz, feldspar, biotite, etc. (Ingersoll et al., 1984). For each thin-section 400 points were counted to attain a maximum error of $5 \%$ at $2 \sigma$ (Van Der Plas and Tobi, 1965). The data was then plotted on various ternary diagrams to help constrain the tectonic setting from which the sandstones were derived (Dickinson and Suczek, 1979).

\subsection{Dense Mineral Analysis}

Due to the small sample sizes available, traditional methods for dense mineral analysis were not possible to be used. Instead, a more qualitative analysis was performed for all ten samples. The portion of disaggregated rock used for the dense mineral analysis included the magnetic fraction of the sample, the light fraction of the MEl that had settled through the LPT, and the heavy fraction of the MEl following the removal of pyrite by $20 \%$ nitric and removal of zircons for mounting. Due to nitric acid soak some dense minerals were dissolved such as apatite and were not considered in the analysis. These grains were then mixed back together 
and made into pressed grain mounts. The grain mounts included a large amount of quartz and rock fragments making point counting of dense minerals using a grid futile. Therefore, to count dense minerals, all dense minerals in a 10x microscope frame were counted before moving to the next frame. This process was repeated until 50 grains were counted for each sample.

\subsection{Log Analysis}

Well log analysis was used to better understand facies distribution within the Norphlet and done using GeoGraphix 10.2. Logs from 32 wells were used to correlate the Norphlet Formation in the offshore federal lease blocks Mobile Bay, Pensacola, and Destin Dome and the

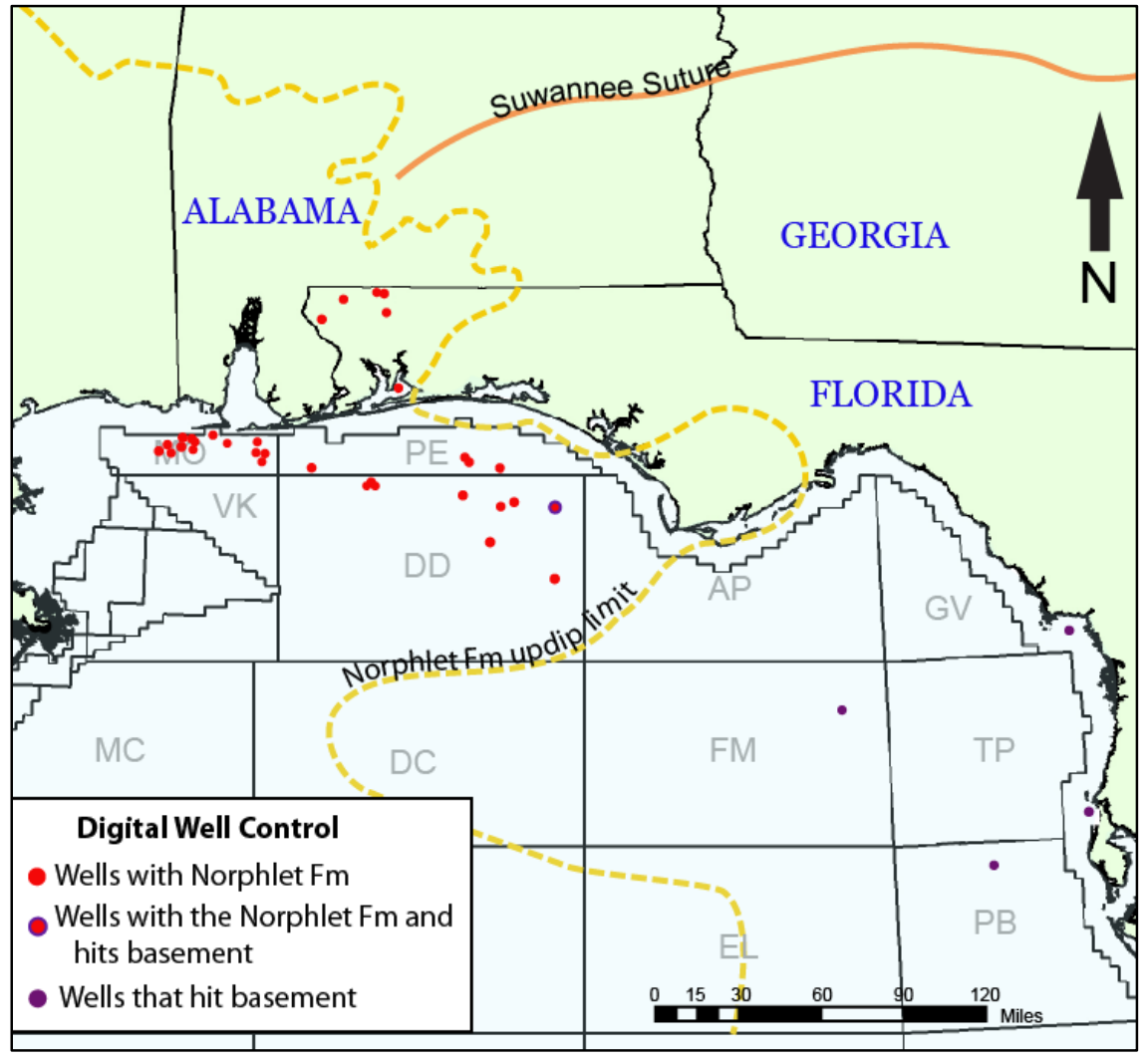

Figure 10. Well control for log analysis in the eastern Gulf of Mexico. western Florida Panhandle.

Beyond the updip limit of

the Norphlet, logs from

four wells that reach

Paleozoic basement in the

Florida Middle Ground and

St. Petersburg federal lease

blocks and offshore Florida

were used to analyze

overlying Jurassic

sediments (Fig. 10).

Offshore wells that

penetrate the Norphlet Formation were provided by the BOEM while offshore wells east of the 
Norphlet updip limit, Florida Middle Ground and St. Petersburg, were provided by TGS. The Florida Geological Survey provided six Florida State well logs.

The distribution of eolian facies in the study area was interpreted based on the average shale volume of the Norphlet Formation. Many of the offshore wells do not penetrate the entirety of the Norphlet therefore, $v$-shale was calculated from the upper portion of Norphlet that was penetrated. Excluded from the average shale volume calculation was the Norphlet basal shale which was only identified in one Destin Dome well (API-608224002100). V-shale calculations were done using Eq. 1 for which clean sandstone gamma ray was defined as $20 \mathrm{API}$ and shale gamma ray was defined as $100 \mathrm{API}$. Calculations were then compared to previous extensive studies on well log facies identified in the Norphlet Formation (Ridgway, 2010; Hunt, 2012) as well as previous paleogeogaphic models (Mancini et al., 1985; Tew et al., 1991; Lovell and Weislogel, 2010). Shale volume calculations were also compared to core obtained from the Oklahoma Geological Survey from the Pensacola well (API-608214000300) to ensure accurate estimation.

Eq. 1: Shale Volume: Vshl[] $=\min (1, \max (0,(G R[]-G R c l n) /(G R s h l-G R c l n)))$

\subsection{Detrital Zircon Grain Size Analysis}

Undergraduate research was undertaken by Evan Knight to see if any correlation existed between grain size of the detrital zircon and age. To do this, the length of each grain that was analyzed for isotopic composition at the Arizona LaserChron lab was determined using a Nikon Eclipse polarizing microscope using reflected light and the NIS Elements image analysis software. 


\section{Results}

\subsection{Sample Descriptions and U-Pb Detrital Zircon Age Distributions}

A total of 867 detrital zircon $\mathrm{U}-\mathrm{Pb}$ ages from the 10 prepared samples were determined to be reliable. Figure 11 shows the concordia plots of the 10 samples. The following discussion includes relative probability plots for each individual sample where the red curve shows the relative probability distribution of $\mathrm{U}-\mathrm{Pb}$ ages including a 2-sigma error. The plots also include a histogram where the number of grains per age are binned in $50 \mathrm{Ma}$ bins. Black bars above the curves represent distinct age groups present in the sample.

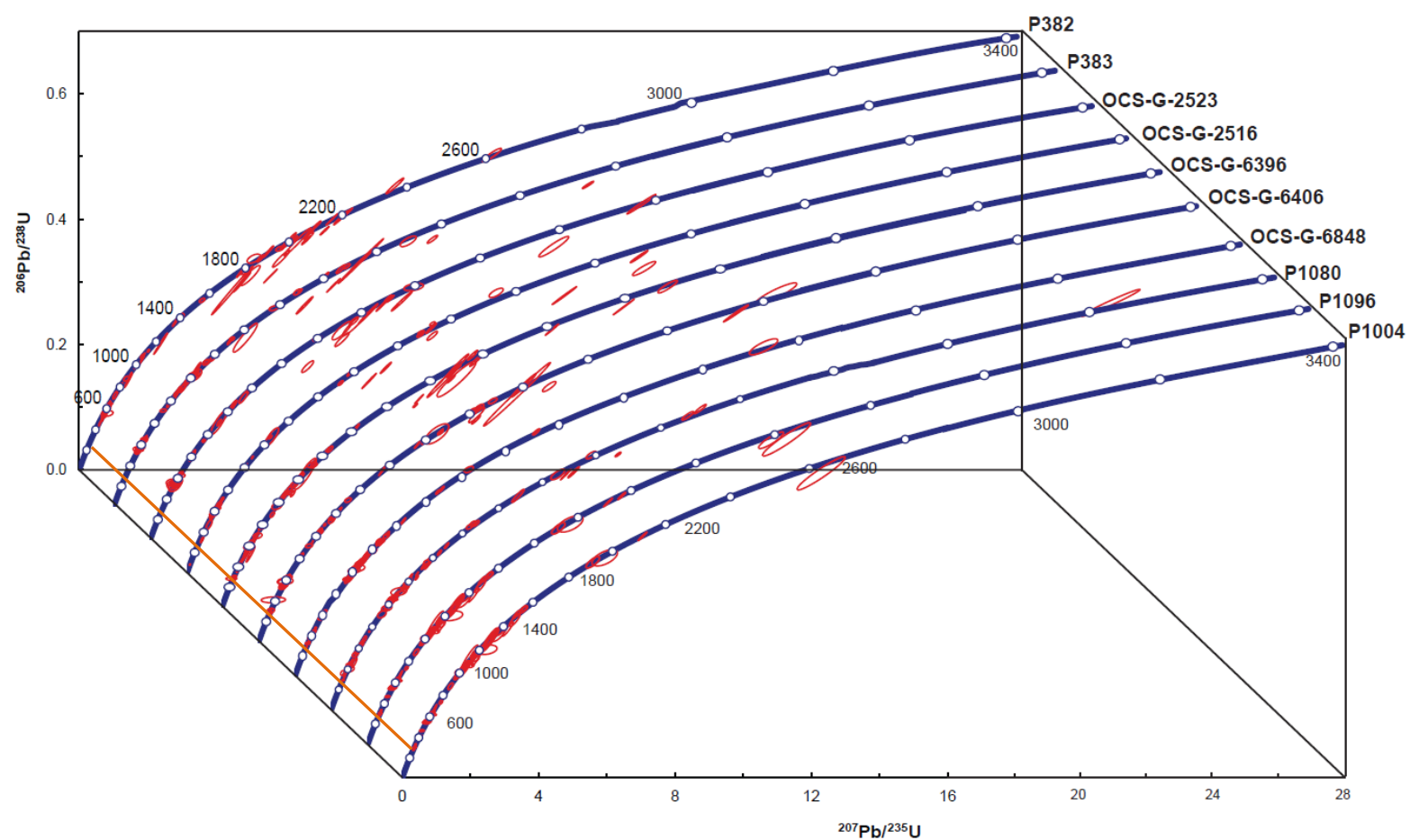

Figure 11. Wetherill concordia plot of all 10 samples. Red ellipses represent single detrital zircon U-Pb analysis with an error of 2-sigma. Orange line indicates deposition age of the Norphlet Formation ( 157 Ma) 


\subsubsection{Sample P1004 - Norphet Formation}

Sample P1004 came from the western

Florida Panhandle and was sampled from core

chips within the Denkman Member of the Norphlet

Formation over a 22 foot-thick interval. It

consisted of light gray, moderately to well sorted,

angular to sub-rounded, medium- to very fine-

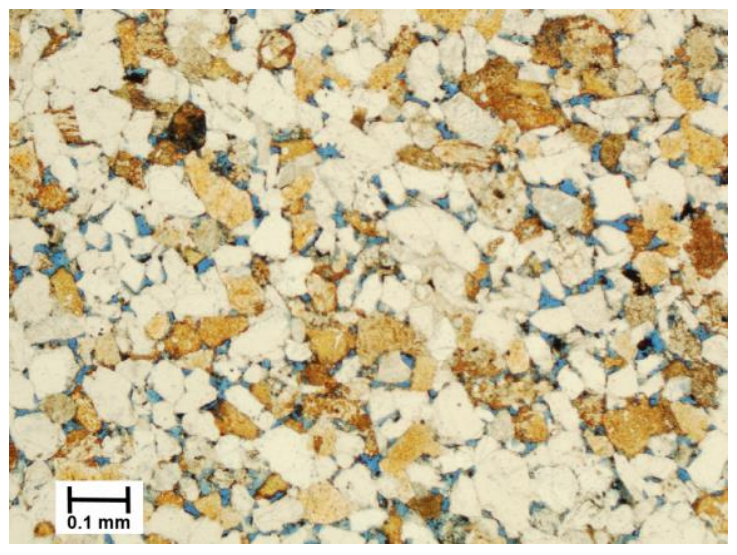

Figure 12. Thin-section image of sample P1004 which consists of moderately to well sorted, angular to subrounded, medium- to very finegrained sand in plane polarized light.

grained sand. No distinct bedding or laminae were observed in the chips or thin-section (Figure

12).

Analysis of sample P1004 provided 95 reliable U-Pb ages; four were removed due to reverse discordance and one removed for discordance. The age range of this sample is from 283.5 Ma (+/- 4.2 Ma) to $2673.2 \mathrm{Ma}(+/-19.5 \mathrm{Ma})$ (Fig. 13A). The majority of the U-Pb ages

A.

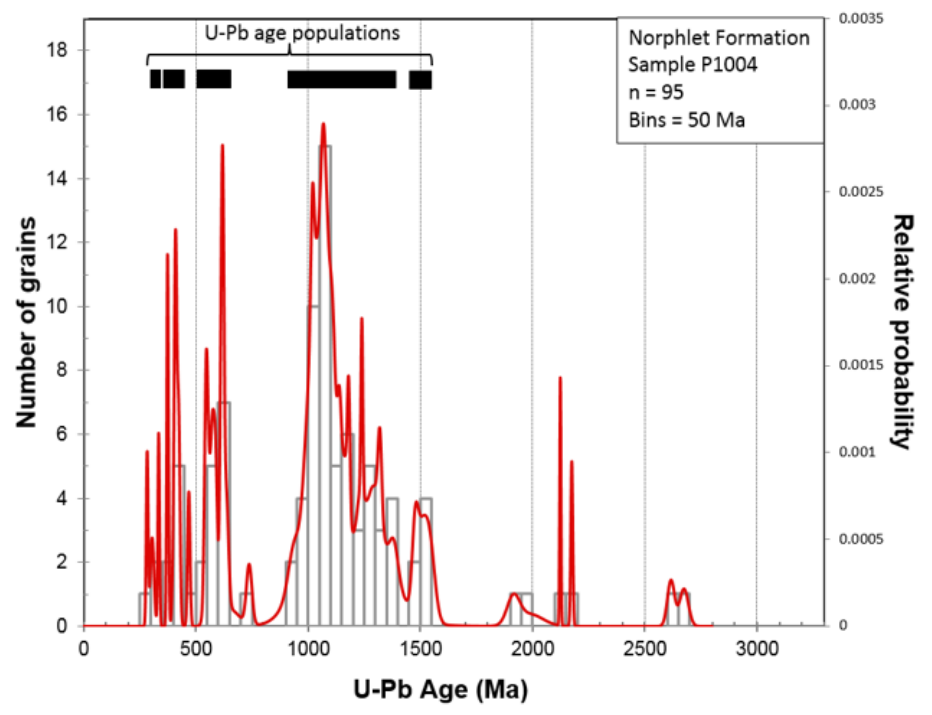

B.
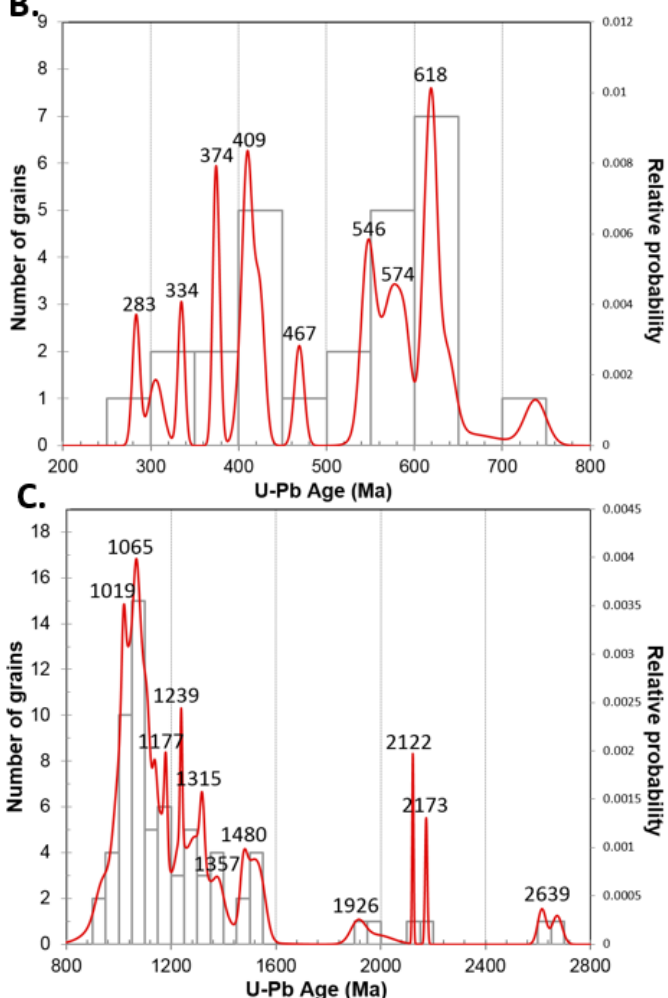

Figure 13. A) Relative probability density curve (red) and histogram in 50 Ma bins showing results of the Norphlet Formation from sample P1004. B) 200-800 Ma age range. C) 800-2800 Ma age range. 
range between 250-650 Ma (26\%; Fig. 12B) and 900-1550 Ma (66\% grains; Fig. 13C). Four U-Pb age populations were identified in this sample; 283-450 Ma (two major peaks at 374 and 409 Ma), 500-650 Ma (peaks at 546, 574, and 618 Ma; Fig. 13B), 900-1400 Ma (peaks throughout including 1019,1065, 1177, 1239, 1315, and $1357 \mathrm{Ma}$ ), and 1450-1550 Ma (peak at $1480 \mathrm{Ma}$; Fig. 13C).

\subsubsection{Sample 1096}

Sample P1096 came from a well in the western Florida Panhandle and was sampled from core chips within the Denkman Member of the Norphlet Formation over a 79 foot interval and is very lithologically similar to sample P1004. It also consists of light gray, moderately to well sorted, angular to subrounded, medium- to very fine-grained sand.

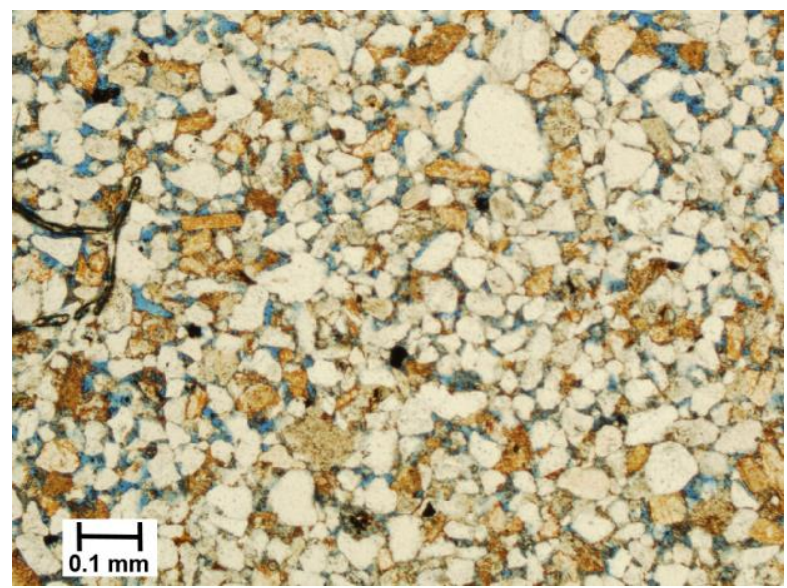
Figure 14. Thin-section image of sample P1096 which consists of moderately to well sorted, angular to subrounded, medium- to very fine-grained sand in plane polarized light.

No distinct bedding or laminae were observed in the chips or thin-section (Fig. 14).

Analysis of sample $\mathrm{P} 1096$ provided 80 reliable U-Pb ages; three were removed due to high ${ }^{206} \mathrm{~Pb} /{ }^{238} \mathrm{U}$ error, two for high ${ }^{206} \mathrm{~Pb} /{ }^{207} \mathrm{~Pb}$ error, one for high ${ }^{204} \mathrm{~Pb}$, three for discordance and 11 for reverse discordance. The age range of this sample is from $330.9 \mathrm{Ma}(+/-6.9 \mathrm{Ma})$ to 2137.4 Ma (+/- 10.1 Ma) (Fig. 15A). Similar to zircon ages of sample P1004, most U-Pb ages range between 300-650 Ma (38\%; Fig. 15B) and 900-1550 Ma (56\%; Fig. 15C). Four main U-Pb age populations were identified; 330-500 Ma (peaks at 374, 431, 463, and $484 \mathrm{Ma}$ ), 500-650 Ma 
(peaks at 535, 583, and $633 \mathrm{Ma}$; Fig. 15B), 900-1250 Ma (peaks at 1011, 1050, 1086, and 1152 Ma), and 1250-1400 Ma (peaks at 1320 and $1390 \mathrm{Ma}$; Fig 15C).
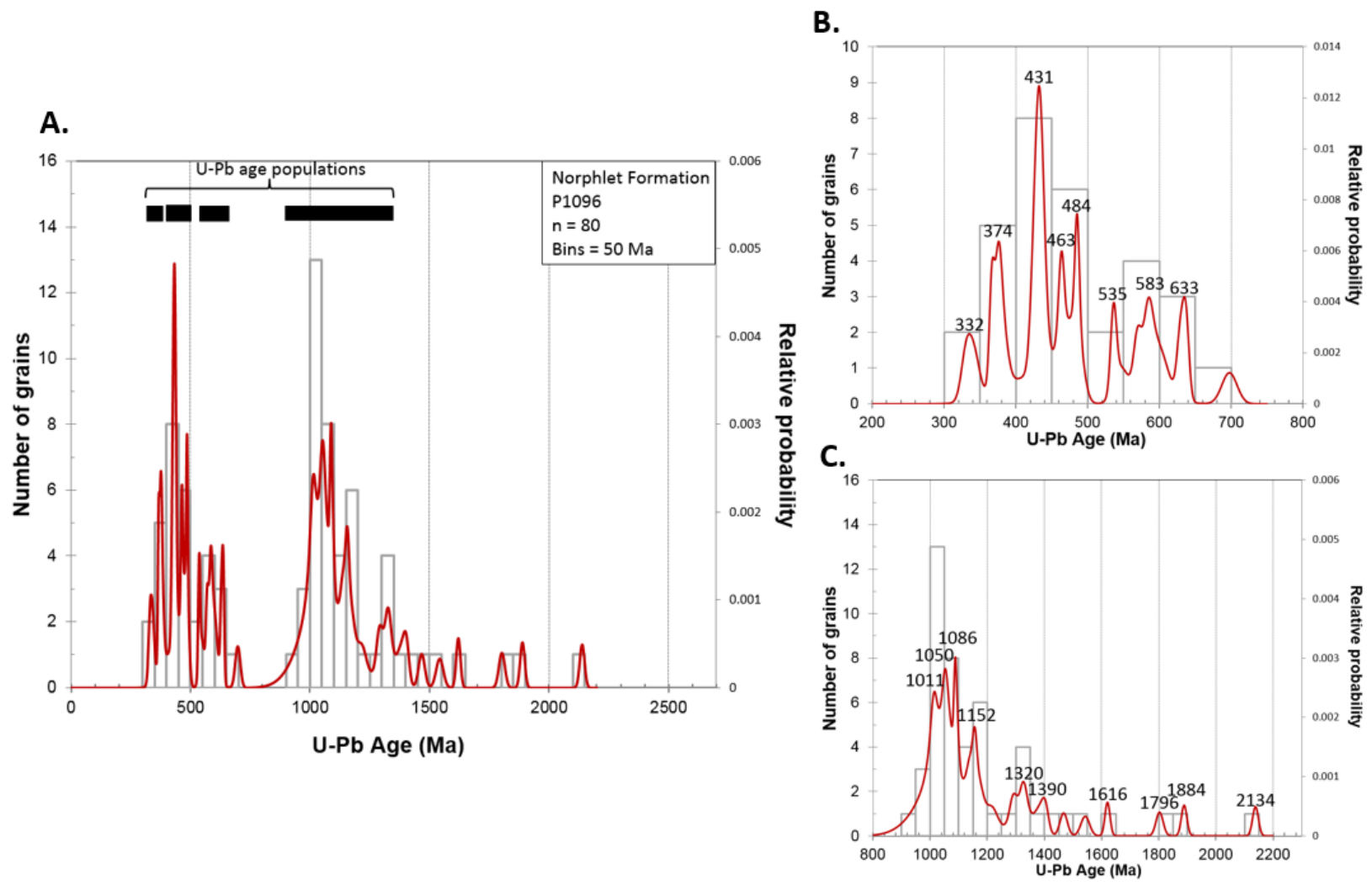

Figure 15. A) Relative probability density curve (red) and histogram in 50 Ma bins showing results of the Norphlet Formation of sample P1096. B) 200-800 Ma age range. C) 800-2200 Ma age range.

\subsubsection{Sample P1080 - Norphlet Formation}

Sample P1080 came from a well in the western Florida Panhandle and was sampled from core chips within the Denkman Member of the Norphlet Formation over a 54 foot thick interval. This sample is lithologically similar to P1004 and P1096 except texturally it shows more angular and larger grains with poorer sorting, which coincides with the sample's more proximal location to the source. It consists of light gray, moderately sorted, angular to subrounded, coarse- to very fine-grained sand. No distinct bedding or laminae were observed in the chips or thin-section (Fig. 16). 
Analysis of sample P1080 provided of 89 reliable

$\mathrm{U}-\mathrm{Pb}$ ages; two were removed due to high ${ }^{206} \mathrm{~Pb} /{ }^{238} \mathrm{U}$

error, one for high ${ }^{204} \mathrm{~Pb}$, three for discordance and five

for reverse discordance. The age range of this sample is

from 295.7 Ma (+/- 3.8 Ma) to 2481.5 Ma (+/- 6.2 Ma)

(Fig 17A). The majority of U-Pb ages range between 295-

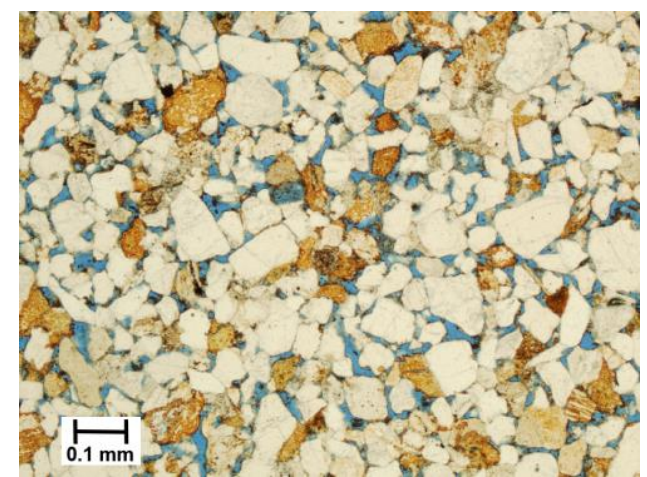

Figure 16. Thin-section image of sample

P1080 which consists of moderately sorted, angular to sub-rounded, coarse- to very fine-grained sand in plane polarized light. $650 \mathrm{Ma}$ (45\%; Fig. 17B) and 900-1550 Ma (40\%; Fig. 17C).

These two predominant $\mathrm{U}-\mathrm{Pb}$ age groups are similar to those of samples P1004 and P1096.

However, samples P1004 and P1096 have a larger percentage of grains between 250-650 Ma where sample P1080 has a larger percentage of grains between 900-1550 Ma. Sample P1080
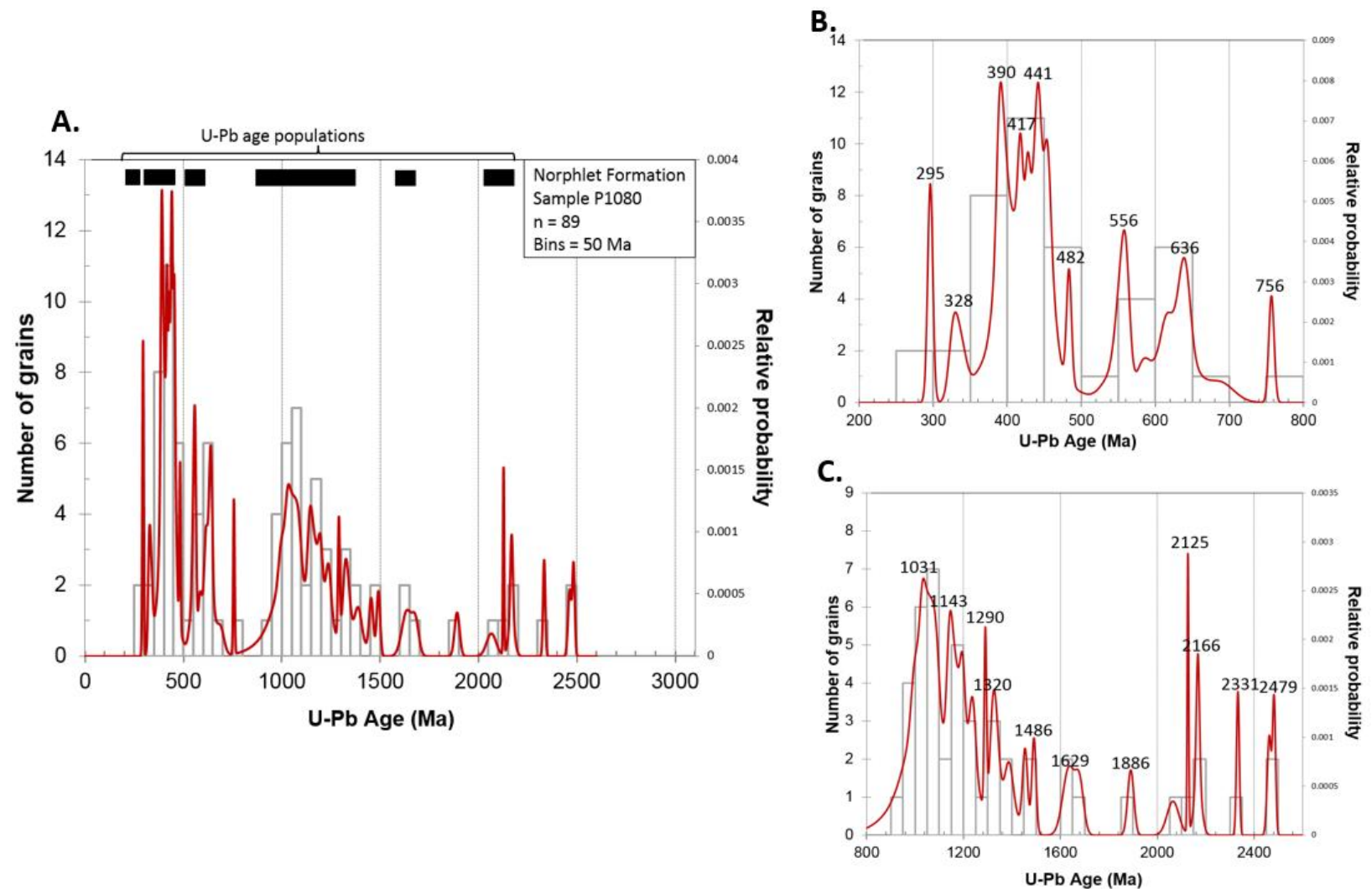

Figure 17. A) Relative probability density curve (red) and histogram in $50 \mathrm{Ma}$ bins showing results of the Norphlet Formation from sample P1080. B) 200-800 Ma age range. C) 800-2600 Ma age range. 
has three major U-Pb age populations and two minor ones; 295-500 Ma (peaks at 295, 390, 417, 441, and $482 \mathrm{Ma}$ ), 500-650 Ma (two peaks at 556 and $636 \mathrm{Ma}$; Fig. 17B), 900-1400 Ma (peaks at 1031, 1143, 1290, and $1320 \mathrm{Ma}$ ), and the two smaller U-Pb age populations 1600 $1700 \mathrm{Ma}$ (peak at $1629 \mathrm{Ma}$ ) and 2050-2200 Ma (peaks at 2125 and $2166 \mathrm{Ma}$; Fig. 17C).

\subsubsection{Sample OCS-G-6848 - Norphlet Formation}

Sample OCS-G-6848 (MO) came from the Mobile Bay offshore lease block and was sampled from cuttings within the Denkman Member of the Norphlet Formation over a 50 footthick interval. The cuttings contained of a large amount of limestone from the overlying Smackover Formation, which were removed with dilute acid. The Norphlet cuttings consisted of fragments of medium gray, medium- to very fine-grained sand. Due to the small size of the sample, none was spared to make a thin-section.

Analysis of sample OCS-G-6848 provided 90 reliable U-Pb ages; one was removed due to high ${ }^{206} \mathrm{~Pb} /{ }^{238} \mathrm{U}$ error, four for discordance, and four for reverse discordance. The age range of this sample is from 293.6 Ma (+/- 4.2 Ma) to $3401 \mathrm{Ma}$ (+/- 6.7 Ma) (Fig. 18A). The majority of U$\mathrm{Pb}$ ages range between 293-650 Ma (37\%; Fig. 18B) and 900-1400 Ma (56\%; Fig. 18C). There are two prominent age populations which include $300-500 \mathrm{Ma}$ (peaks at 369, 388, 421, and 455 Ma; Fig. 18B) and 900-1400 Ma (peaks at 1013, 1060, 1154 and 1301 Ma; Fig. 18C). Another smaller age population present is 550-650 Ma (peaks at 570, 589, and $624 \mathrm{Ma}$; Fig. 18B). 

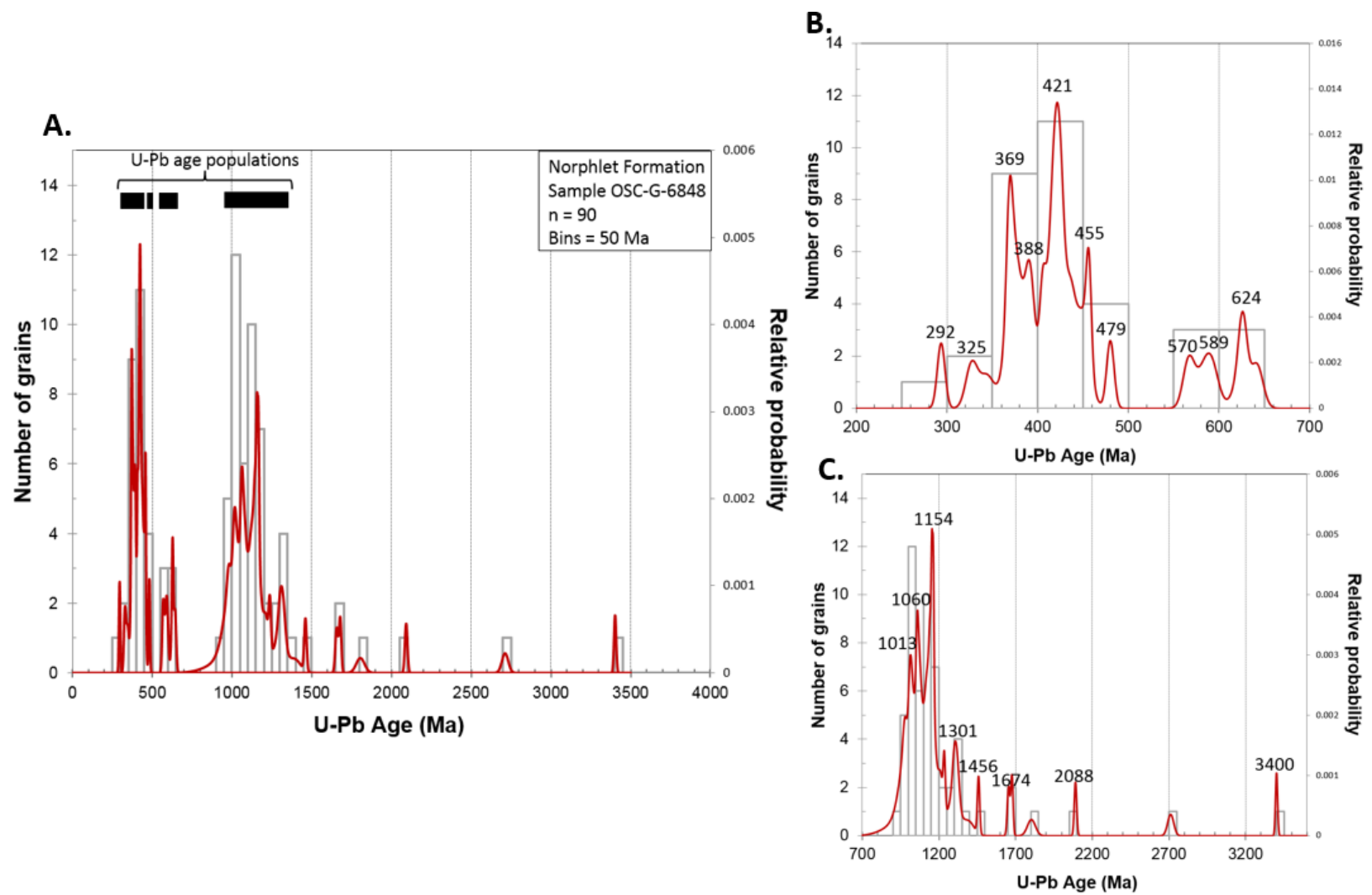

Figure 18. A) Relative probability density curve (red) and histogram in 50 Ma bins showing results of the Norphlet Formation from sample OCS-G-6848. B) 200-700 Ma age range. C) 700-3700 Ma age range.

\subsubsection{Sample OCS-G-6406 - Norphlet Formation}

Sample OCS-G-6406 (DD) came from the Destin Dome

offshore lease block and was sampled from core chips within

the Denkman Member of the Norphlet Formation over a 180

foot thick interval. It consisted of very thin laminae of

alternating coarse- and very fine-grained sand lamina that

showed both reverse and normal grading. The grains within

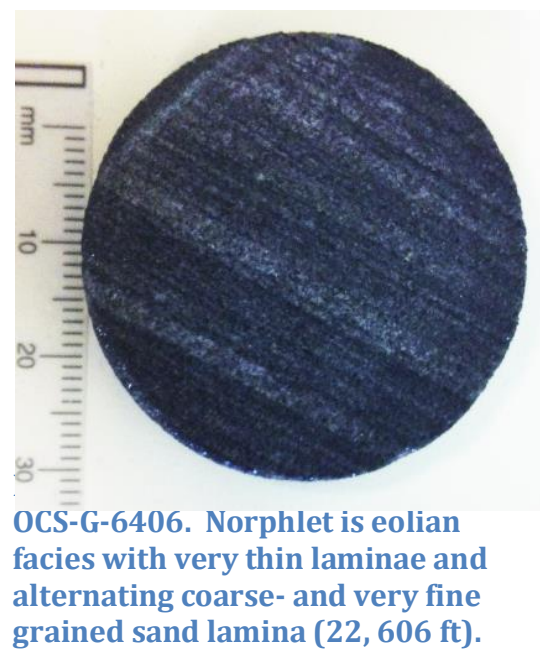

the laminae are well sorted and are sub-angular to well-rounded. The top of the Norphlet

Formation is dark gray/black with hydrocarbon staining which decreases with depth becoming a

light gray/beige at the bottom (Fig. 19). 
Analysis of sample OCS-G-6406 provided 88 reliable U-Pb ages; two were removed due to high ${ }^{206} \mathrm{~Pb} /{ }^{238} \mathrm{U}$ error, one for high ${ }^{204} \mathrm{~Pb}$, three for discordance, and six for reverse discordance. The age range of this sample is from 199.1 Ma (+/- 10.7 Ma) to 3093.2 Ma (+/16.6 Ma) (Fig. 20A). This sample has the youngest zircons out of the 10 samples with two Triassic-aged zircon (199.1 and 212.1 Ma). The majority of U-Pb ages range between 273-700 Ma (52\%; Fig. 20B), 1000-1400 Ma (23\%; Fig. 20B), and 2050-2200 Ma (13\%; Fig. 20C). The two largest age populations include 500-700 Ma ages (high peaks at $542 \mathrm{Ma}$ and $602 \mathrm{Ma}$ ) and 1000$1350 \mathrm{Ma}$ ages (peaks at $1045 \mathrm{Ma}$ and $1117 \mathrm{Ma}$; Fig. 20B). Two less abundant age populations include 250-500 Ma (peaks at $302 \mathrm{Ma}$ and $423 \mathrm{Ma}$; Fig. 20B) and 2050-2200 Ma (peaks at 2050, 2094, and 2122 Ma; Fig. 20C).

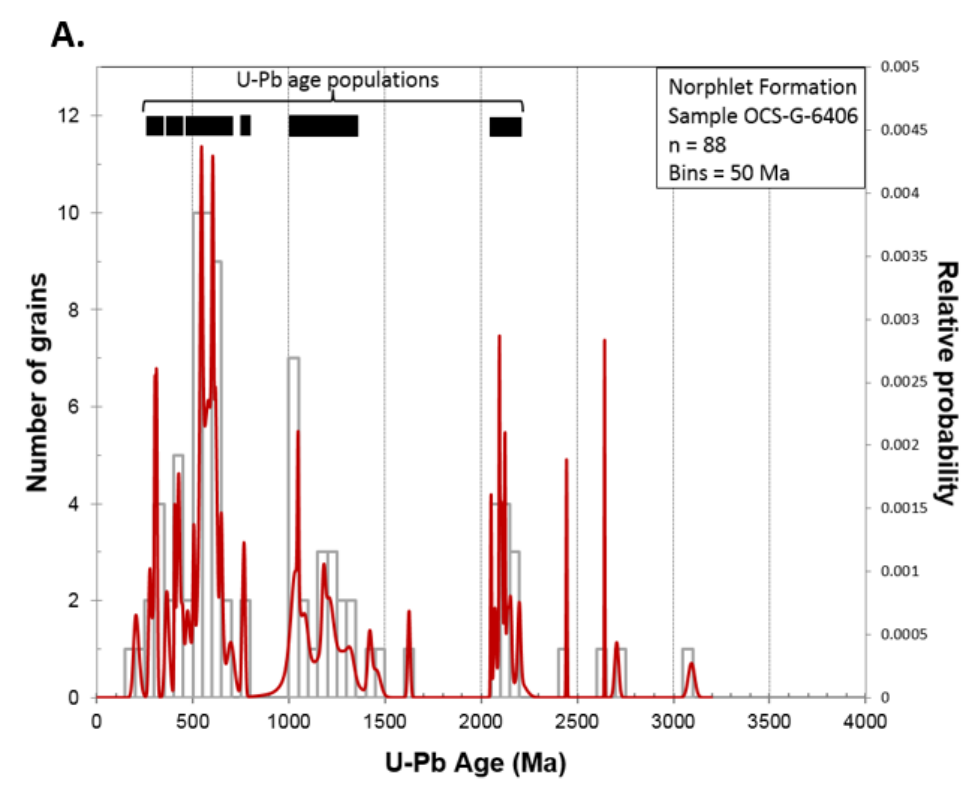

B.
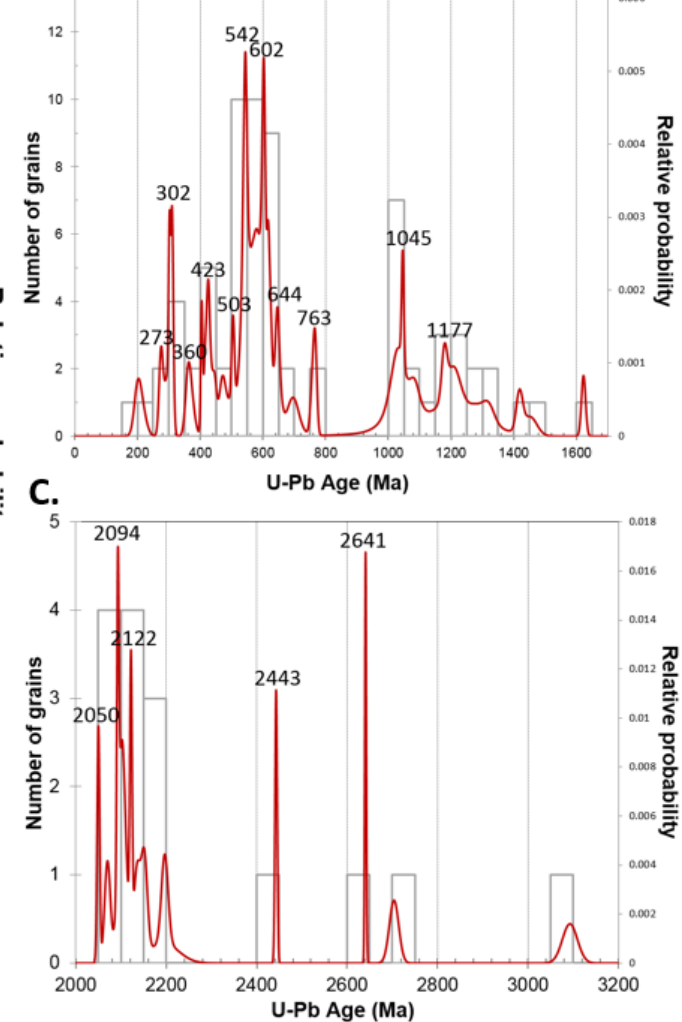

Figure 20. A) Relative probability density curve (red) and histogram in 50 Ma bins showing results of the Norphlet Formation from sample OCS-G-6406. B) 0-1700 Ma age range. C) 2000-3200 Ma age range. 


\subsubsection{Sample OCS-G-6396 - Norphlet Formation}

Sample OCS-G-6396 came from the Pensacola offshore lease block and was sampled from core within the Denkman Member of the Norphlet Formation over a 19 foot interval. Similar to sample OCS-G-6406, it consisted of very thin laminae of alternating coarse- and very fine-grained sand lamina that showed both reverse and normal grading. The grains within the laminae are well sorted and are sub-angular to well-rounded. The top of the core contained carbonate cement which decreased rapidly with depth and was absent below four feet. There is some hydrocarbon staining causing a medium-gray color which decreases with depth turning to light gray. The core also showed scours within some laminae as well as a burrowed section (Fig. 21).

Analysis of the sample OCS-G-6396 provided 89 reliable U-Pb ages; two were removed due to high ${ }^{206} \mathrm{~Pb} /{ }^{238} \mathrm{U}$ error, one for high ${ }^{204} \mathrm{~Pb}$, three for discordance, and five for reverse discordance. The age range of this sample is from 202.1 Ma (+/- 16.7 Ma) to 2766.6 Ma (+/- 3.7 Ma) (Fig. 22A). Similar to the Destin Dome sample, this sample also has a single young, Triassicaged zircon. Unlike the other samples, the U-Pb ages are more evenly distributed with less clustering. The majority of U-Pb ages range between 250-700 Ma (56\%; Fig 22B), 900-1300 Ma (22\%; Fig. 22B), and 1700-2250 Ma (15\%; Fig. 22C). The two largest age populations include 500-700 Ma (peaks at $551 \mathrm{Ma}$ and $623 \mathrm{Ma}$ ) and 900-1300 Ma (age peaks at 977, 1030, and 1221 Ma; Fig. 22B). Three less abundant age populations include 250-350 Ma (age peaks at $293 \mathrm{Ma}$ and $318 \mathrm{Ma}$ ), 400-450 Ma (age peaks at $412 \mathrm{Ma}$ and $430 \mathrm{Ma}$; Fig 22B), and 1950-2250 Ma (age peaks at 2032, 2092, and 2192 Ma; Fig. 22C). 


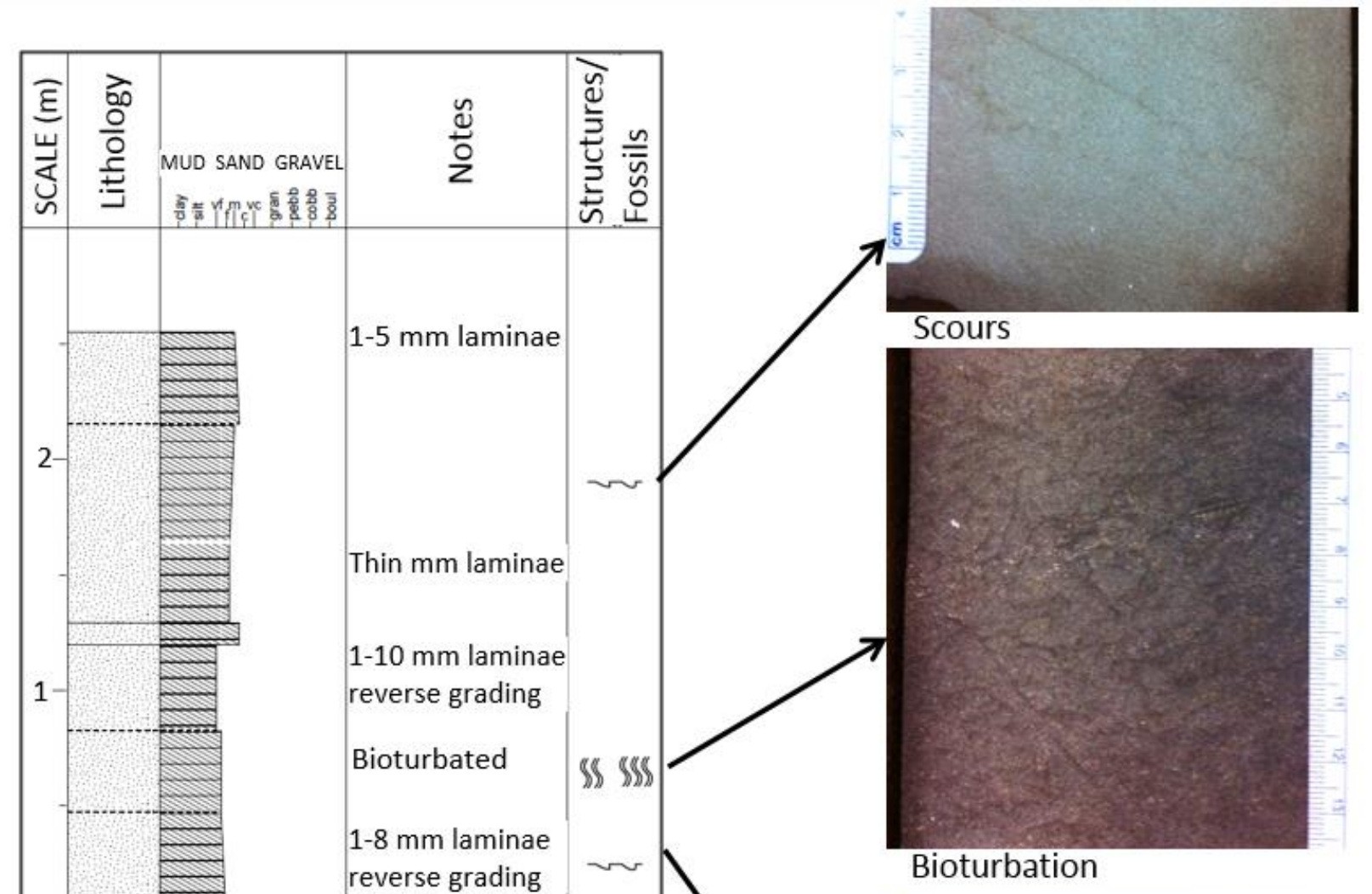

Depth interval: $17,558-17,567$ feet

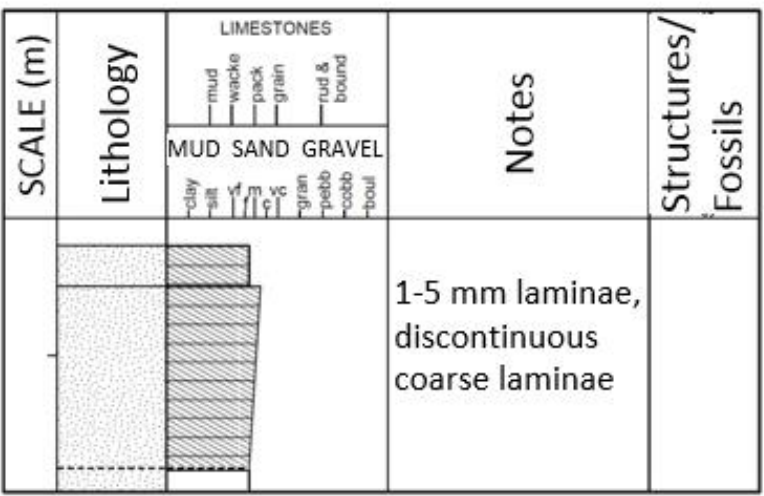

Depth interval: $17,584-17,587$ feet

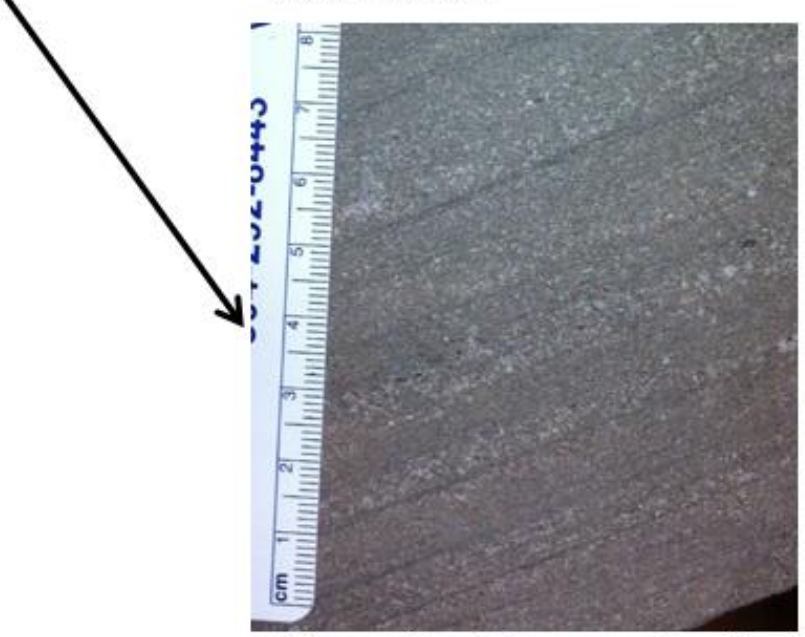

Normal and Reverse Grading

Figure 21. Core description and images of the Norphlet Formation from sample 0CS-G-6396. The sample consisted of very thin laminae of alternating coarse- and very fine-grained sand lamina that showed both reverse and normal grading. Sedimentary structures include scours, bioturbation and normal and reverse graded beds. 

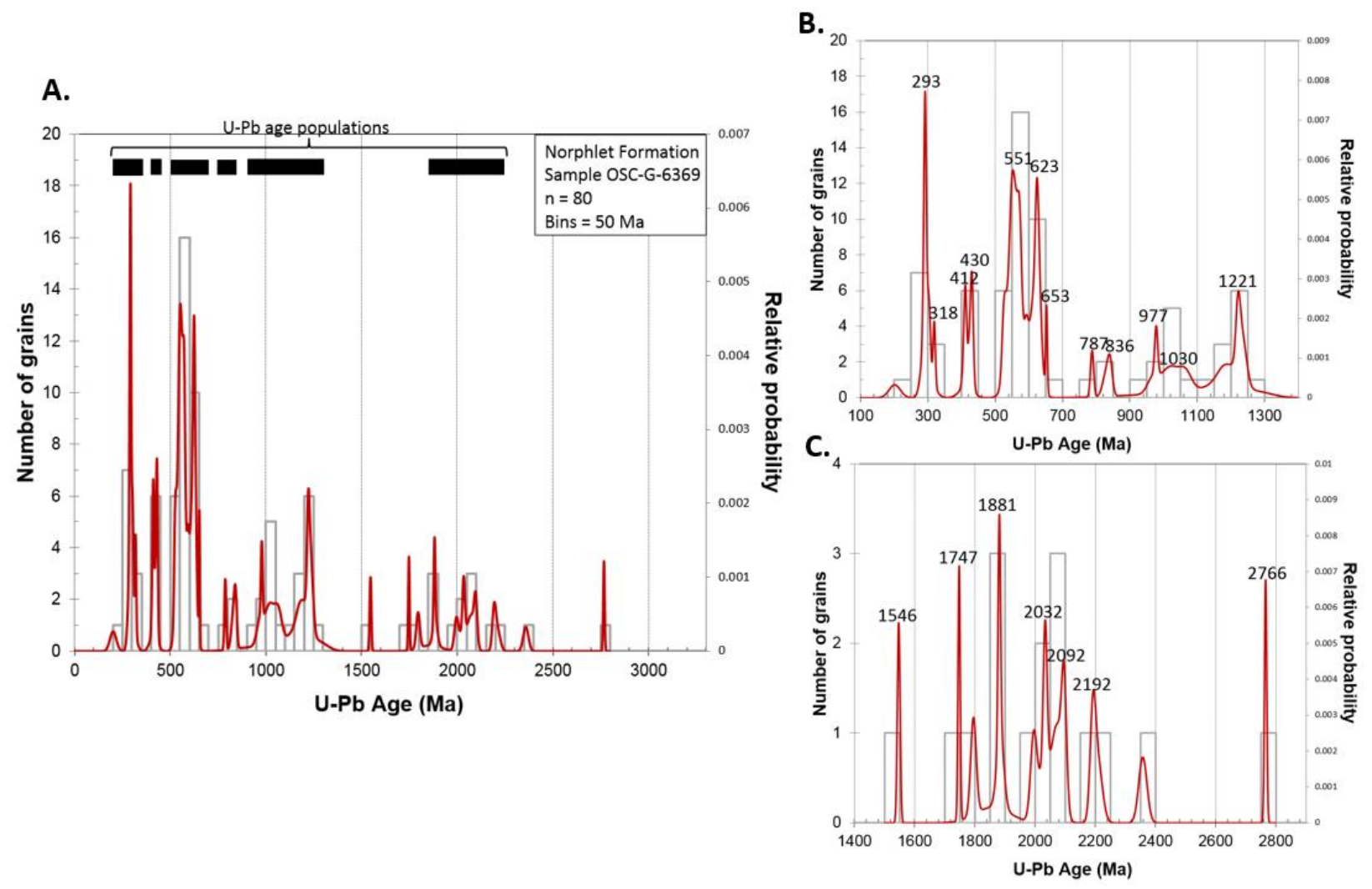

\subsubsection{Sample OCS-G-2516 - Haynesville Formation and Paleozoic Basement}

Figure 22. A) Relative probability density curve (red) and histogram in 50 Ma bins showing results of the Norphlet Formation from sample OCS-G-6396. B) 100-1400 Ma age range. C) 1400-2900 Ma age range.

Sample OCS-G-2516 (FMG) came from the

Florida Middle Ground offshore lease block and

was sampled from cuttings recovered from the

Haynesville Formation and Paleozoic basement

over a 55 foot interval. The cuttings consisted of

pieces of shale, siltstone, sandstone, and quartzite

(Fig 23).

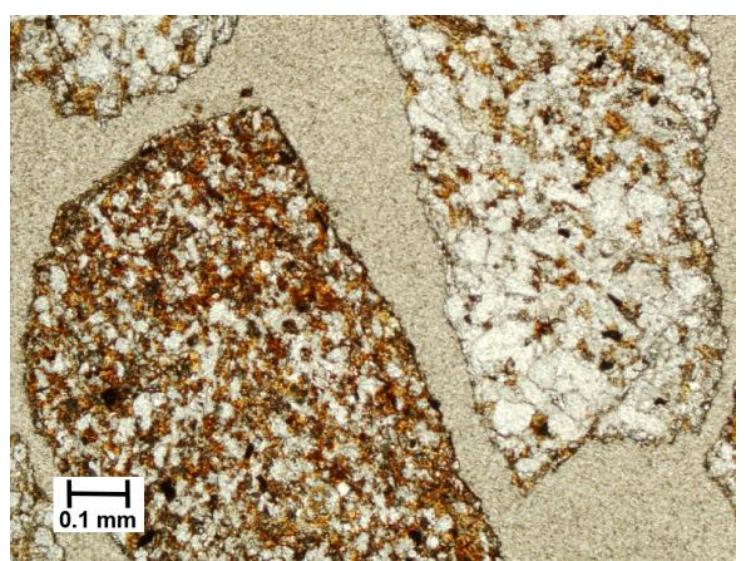

Figure 23. Thin-section image of cuttings from sample OCS-G-2516 which consists of shale, siltstone, sandstone, and quartzite in plane polarized light.

Analysis of sample OCS-G-2516 provided of 75 reliable U-Pb ages; two were removed due to high ${ }^{206} \mathrm{~Pb} /{ }^{238} \mathrm{U}$ error, one due to high ${ }^{206} \mathrm{~Pb} /{ }^{207} \mathrm{~Pb}$ error, one for high ${ }^{204} \mathrm{~Pb}$, ten for discordance, and eleven for reverse discordance. The youngest zircon examined was 

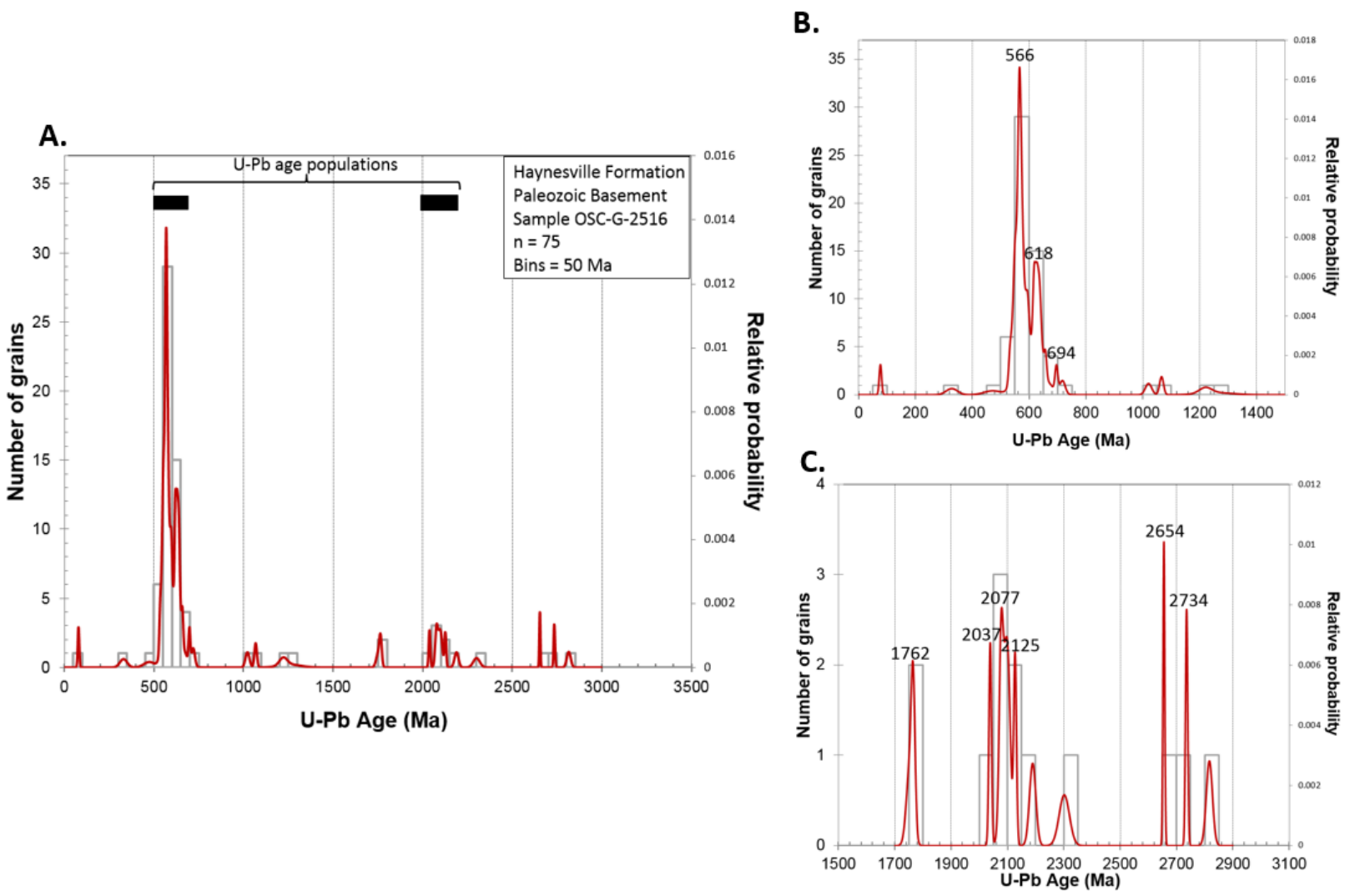

Figure 24. A) Relative probability density curve (red) and histogram in 50 Ma bins showing results of the Haynesville Formation and Paleozoic basement from sample OCS-G-2516. B) 0-1500 Ma age range. C) 15003100 Ma age range.

77.4 $\mathrm{Ma}(+/-4.2)$, much younger than the formation age and is considered to be a result of contamination due to the sampling of cuttings and mixing of younger sediments via well bore circulation during drilling. The detrital zircon age range of this sample is from $328.8 \mathrm{Ma}(+/-$ 20.3 Ma) to $2815.9 \mathrm{Ma}$ (+/- 10.9 Ma) (Fig. 24A). The majority of U-Pb ages range between 450$750 \mathrm{Ma}$ (75\%; Fig. 24A) and 2000-2350 Ma (11\%; Fig. 24B). There are only two prominent age populations for this sample which include 500-700 Ma (peaks at $566 \mathrm{Ma}$ and $618 \mathrm{Ma}$; Fig. 24B) and 2000-2200 Ma (age peaks at 2037, 2077, and $2125 \mathrm{Ma}$; Fig. 24C). 


\subsubsection{Sample OCS-G-2523 - Cotton Valley Group, Haynesville Formation, and Paleozoic Basement}

Sample OCS-G-2523 (STPB) came from the St.

Petersburg offshore lease block and was sampled from

cuttings within the Cotton Valley Group, Haynesville

Formation, and Paleozoic basement over a 90 foot thick

interval. The cuttings consisted of pieces of shale,

siltstone, sandstone, and quartzite (Fig. 25).

Analysis of sample OCS-G-2523 provided 88

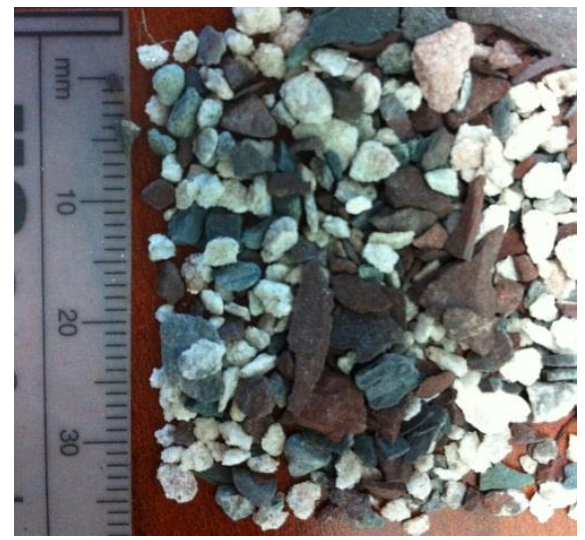

Figure 25. Cuttings from sample OCS-G2523 consisting of shale, siltstone, sandstone and quartzite.

reliable U-Pb ages; one was removed for high ${ }^{204} \mathrm{~Pb}$, six for discordance, and eight for reverse discordance. The age range of this sample is from 516.0 Ma (+/- 4.3 Ma) to 2771.1 Ma (+/- 4.8 Ma) (Fig. 26A). The majority of U-Pb ages fall between 500-650 Ma (72\%; Fig, 26B), 800-1400 Ma (11\%; Fig. 26B), and 1950-2250 Ma (13\%; Fig. 26B). Similar to the Florida Middle Ground sample, only two prominent age populations occur; 500-650 Ma (peaks at $556 \mathrm{Ma}$ and $637 \mathrm{Ma}$; Fig. 26B) and 1950-2250 Ma (age peaks at 1995, 2061, 2105, and $2218 \mathrm{Ma}$; Fig. 26C). 

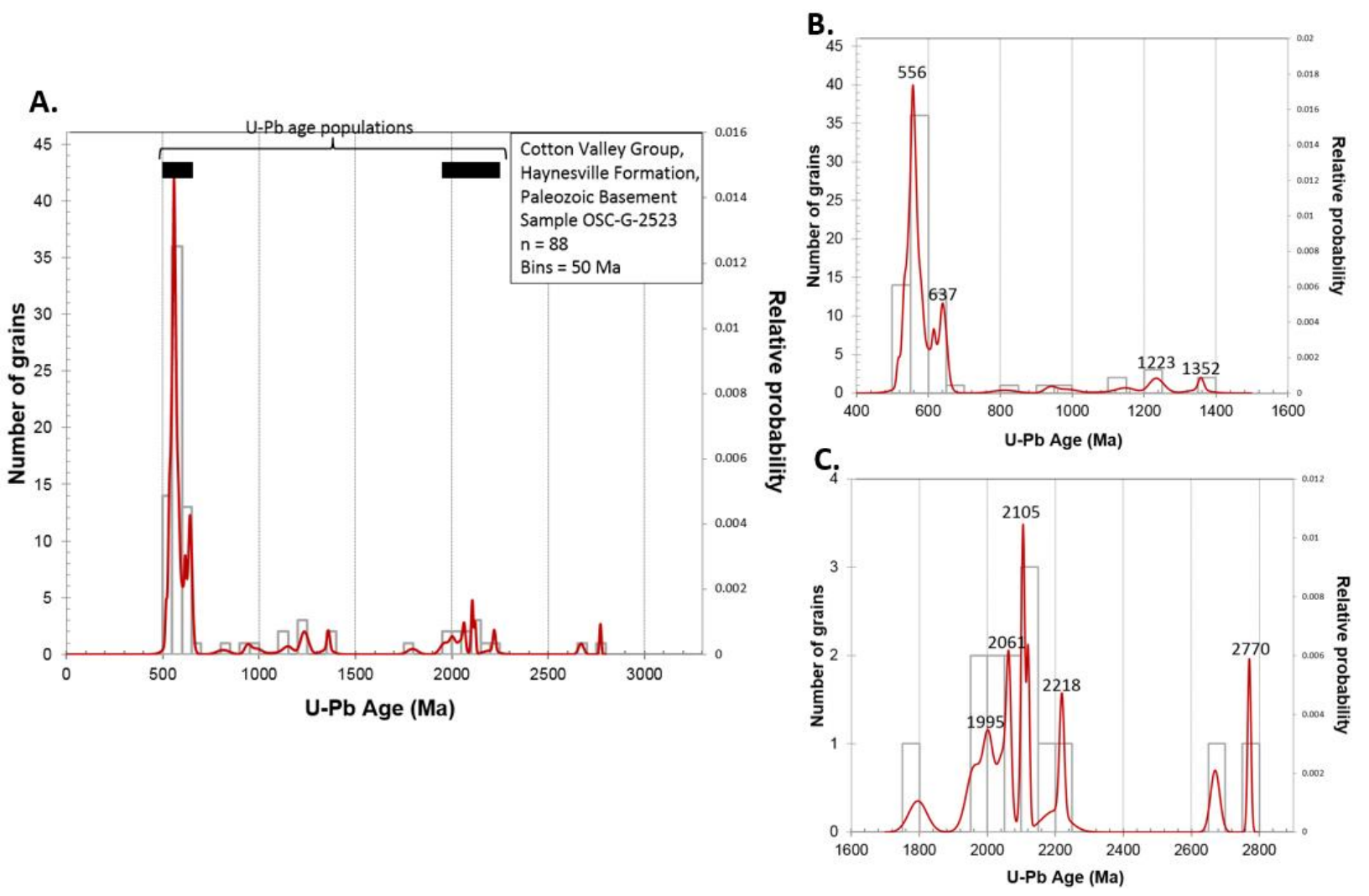

Figure 26. A) Relative probability density curve (red) and histogram in 50 Ma bins showing results of the Cotton Valley Group, Haynesville Formation, and Paleozoic basement from sample OCS-G-2523. B) 400-1600 Ma age range. C) 1600-2900 Ma age range.

\subsubsection{Sample P383 - Paleozoic Basement}

Sample P383 came from the Florida State

offshore waters east of the Gainesville offshore

lease block and was sampled from core chips and

cuttings within the Paleozoic basement over a

220 foot thick interval. The core chips consisted

of sandstone and quartzite and the cuttings

consisted of quartzite, shale, and siltstone (Fig.

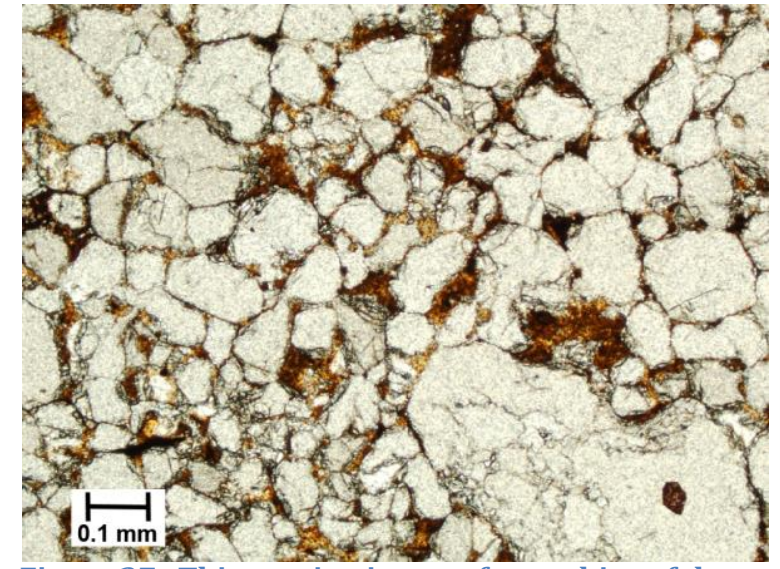

Figure 27. Thin-section image of core chips of the Paleozoic basement from sample P383 consisting of sandstone in plane polarized light.

27). 
Analysis of sample P383 provided 88 reliable U-Pb ages; one was removed for high ${ }^{204} \mathrm{~Pb}$, one for discordance, and ten for reverse discordance. The age range of this sample is from 526.2 Ma (+/- 4.9 Ma) to 2799.8 Ma (+/- 3.7 Ma) (Fig. 28A). The majority of U-Pb ages range between 500-700 Ma (50\%; Fig. 28B), 800-1900 Ma (40\%; Fig. 28B), and 1950-2200 Ma (7\%; Fig. 28C). Unlike the Florida Middle Ground and St. Petersburg sample, P383 has three prominent age populations; 500-700 Ma (peaks at 550, 626 and $652 \mathrm{Ma}$ ), 950-1350 Ma (two peaks at 1013 Ma and 1214 Ma; Fig. 28B), and 1950-2200 Ma (peaks at 1990, 2050, 2133, and 2155 Ma; Fig. 28C).
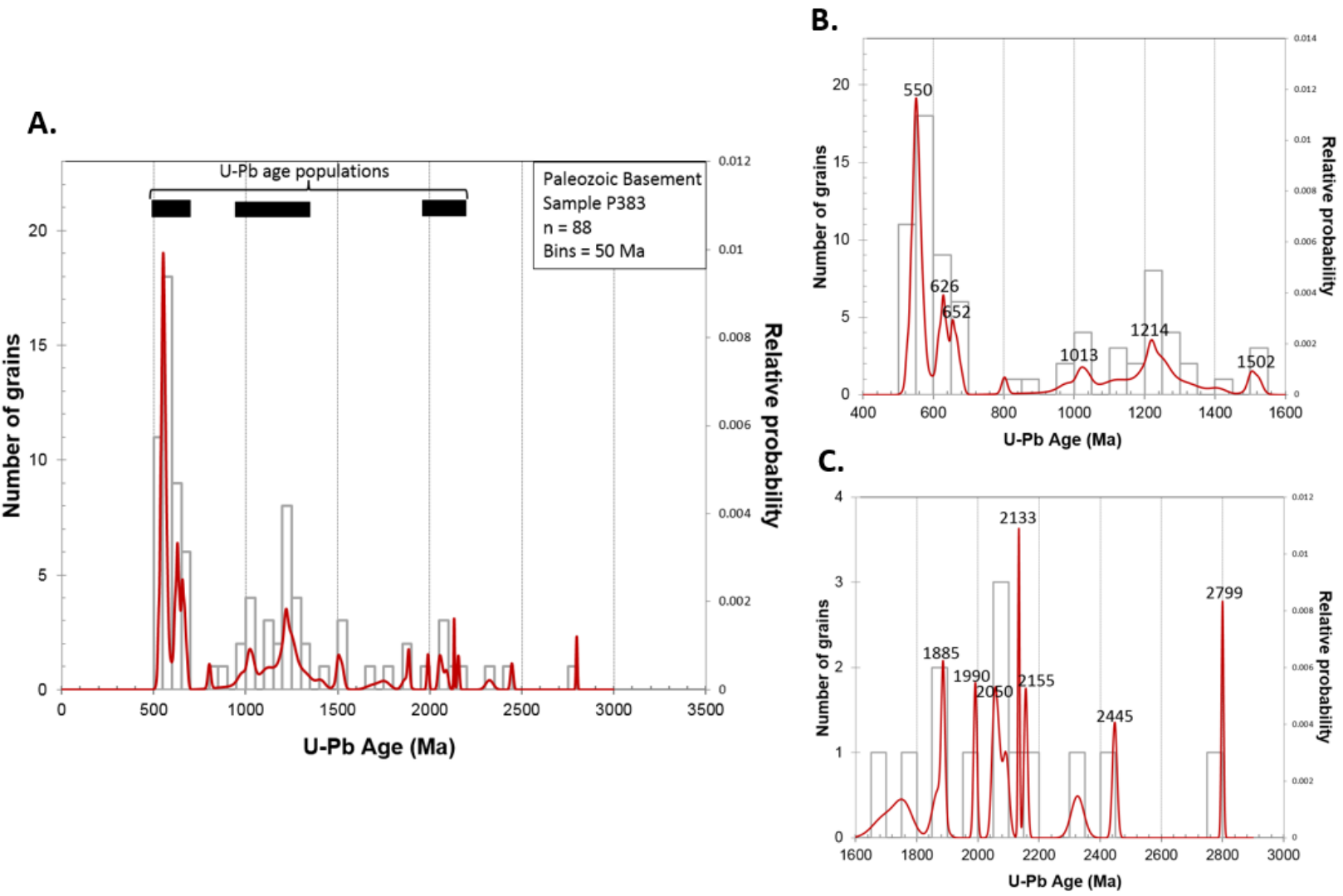

Figure 28. A) Relative probability density curve (red) and histogram in 50 Ma bins showing results of the Paleozoic basement from sample P383. B) 400-1600 Ma age range. C) 1600-3000 Ma age range. 


\subsubsection{Sample P382 - Paleozoic Basement}

Sample P382 came from the Florida State offshore waters east of the Tarpon Springs

offshore lease block and was sampled from core chips within the Paleozoic basement over an 11 foot thick interval. The core chips consisted of quartzite, shale, and siltstone (Fig. 29).

Analysis of the sample P382 provided 85 reliable $\mathrm{U}-\mathrm{Pb}$ ages, one was removed due to high ${ }^{206} \mathrm{~Pb} /{ }^{207} \mathrm{~Pb}$ error, six for high ${ }^{204} \mathrm{~Pb}$, one for discordance, and seven for reverse discordance. The age range of this sample is from 456.4 Ma (+/- 18.1 Ma) to 2605.5 Ma (+/- $9.8 \mathrm{Ma})$ (Fig. 30A). The majority of $\mathrm{U}-\mathrm{Pb}$ ages range between 450-650 Ma (51\%; Fig. 30B), 800-1600 Ma (16\%; Fig.

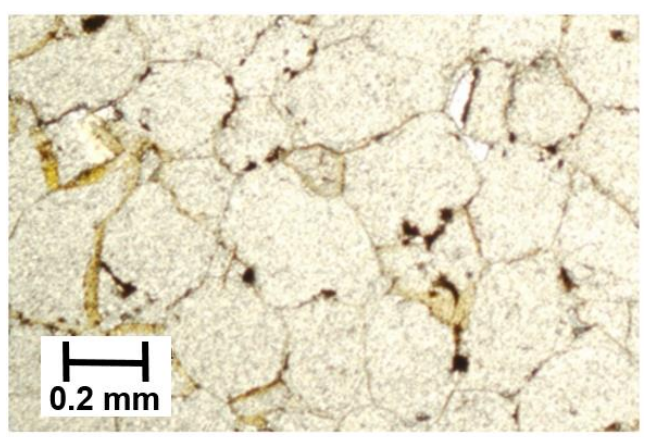

A.

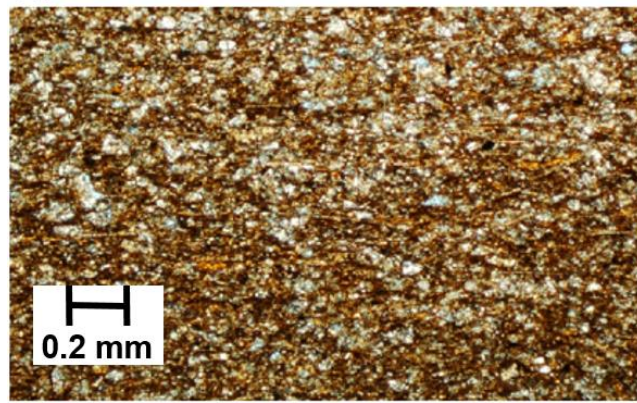

B.

Figure 29. Thin-section images of the Paleozoic basement from sample P382 in plane polarized light. A) Quartzite from $6,046 \mathrm{ft}$. B) Shale from $6,044 \mathrm{ft}$.

30B), and 1750-2350 Ma (28\%; Fig. 30C). Similar to sample P383 to the north, P382 has three prominent age populations; 450-650 Ma (peaks at 493, 553 and $620 \mathrm{Ma}$ ), 950-1200 Ma (two peaks at $983 \mathrm{Ma}$ and $1067 \mathrm{Ma}$; Fig. 30B), and 2050-2250 Ma (age peaks at 2095, 2121, 2160, 2188, and 2218 Ma; Fig, 30C). However, P382 has a small age population from 1750-1900 Ma with peaks at $1785 \mathrm{Ma}$ and $1889 \mathrm{Ma}$ that is not present in any of the other samples. 

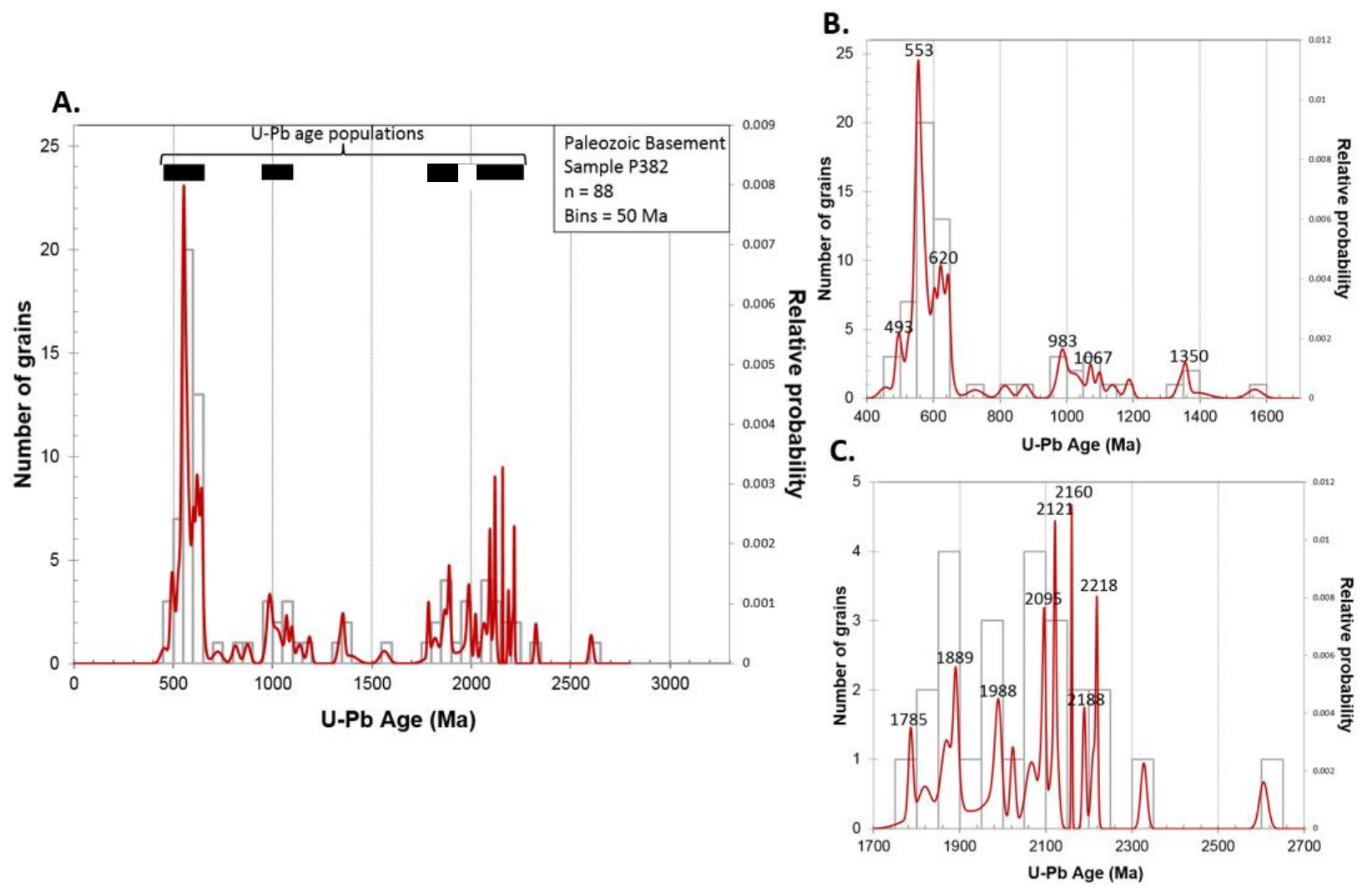

Figure 30. A) Relative probability density curve (red) and histogram in 50 Ma bins showing results the Paleozoic basement from sample P382. B) 400-1700 Ma age range. C) 1700-2700 Ma age range.

\subsection{Shared Age Populations and Peak Age Correlation}

The ten samples show several major and overlapping $\mathrm{U}-\mathrm{Pb}$ age populations. Figure 31 shows normalized relative probability plots of the ten samples. This figure highlights the similarity of the four southeastern samples OCS-G-2516, OCS-G-2523, P383 and P382 and their overall difference from the other six samples. Figure 32 shows the major age populations as black boxes from all samples for comparison. The predominant age groups include 250-500 $\mathrm{Ma}, 500-700 \mathrm{Ma}, 900-1400 \mathrm{Ma}$, and 1950-2250 Ma. The youngest age group from 250-500 Ma is shared between the Florida Panhandle wells (P1004, P1096, and P1080), Mobile Bay (MO, OCS-G-6848), Destin Dome (DD, OCS-G-6406), and Pensacola (PE, OCS-G-6396) samples. The 500-700 Ma zircon age population is shared between all samples 


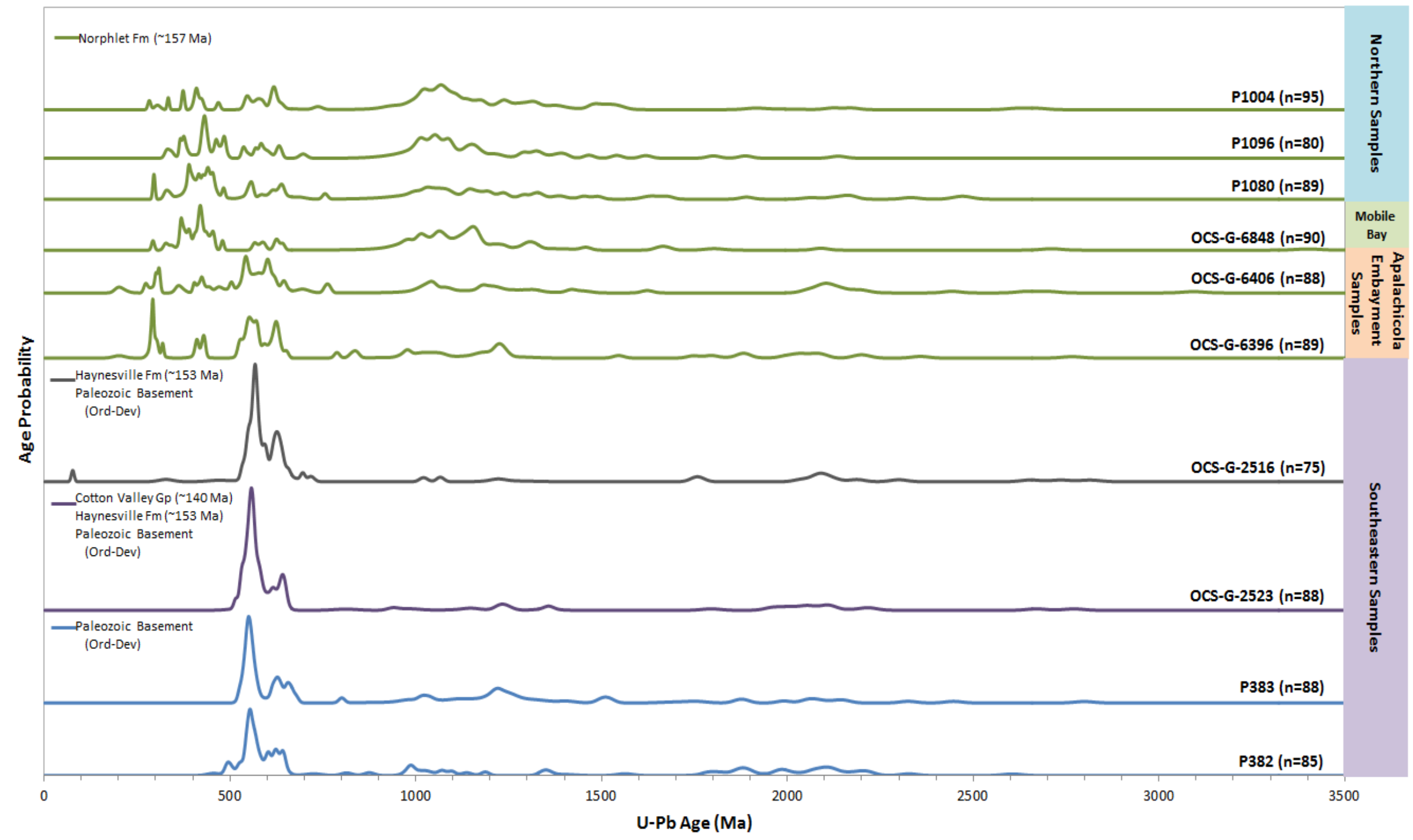

Figure 31. Cumulative relative probability plots for all 10 detrital zircon samples. Green line indicates a Norphlet Formation samples, gray indicates Haynesville Formation and basement, purple indicates Cotton Valley Group, Haynesville Formation, and basement, and blue indicates Paleozo ic basement. 


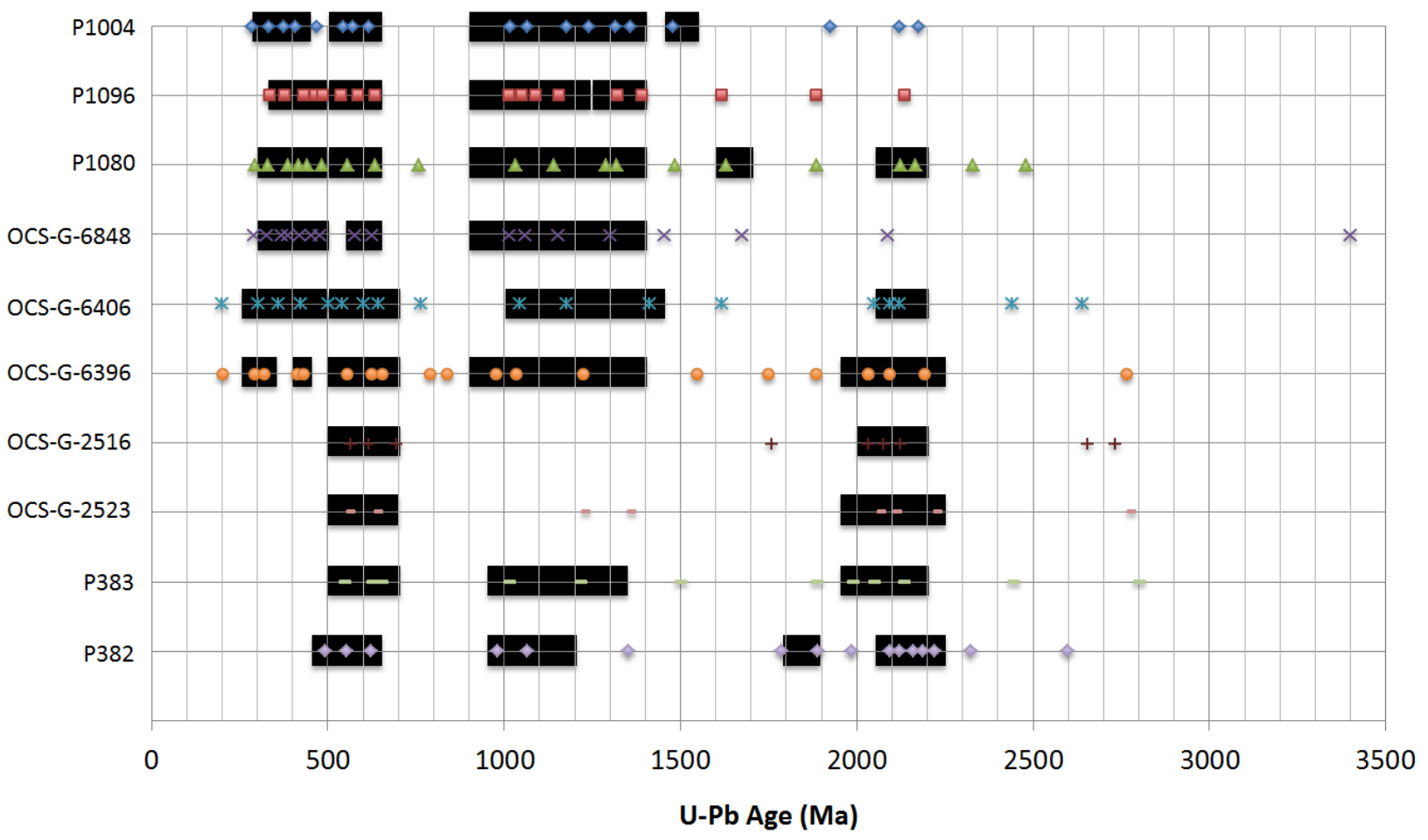

Figure 32. Prominent U-Pb age populations for each sample (black box) with age peaks that occur within relative probability curves.

and overall increases in abundance southward. Age group 900-1400 Ma is particularly

abundant in the northern study area and is shared by all samples with the exception of the

Florida Middle Ground (FMG, OCS-G-2516) and St. Petersburg (STPB, OCS-G-2523) samples.

Table 2. Table of the four most abundant $\mathrm{U}-\mathrm{Pb}$ age populations and samples that contain those populations.

\begin{tabular}{|l|l|}
\hline U-Pb Age Population & Samples \\
\hline 250-500 Ma & P1004 (12\%), P1096 (26\%), \\
& P1080 (33\%), MO (30\%), \\
& DD (19\%), PE (19\%) \\
\hline $500-700 \mathrm{Ma}$ & P1004 (15\%), P1096 (13\%), \\
& P1080 (13\%), MO (7\%), \\
& DD (35\%), PE (37\%), \\
& FMG (72\%), STPB (73\%), \\
& P383 (50\%), P382 (47\%) \\
\hline $900-1400 \mathrm{Ma}$ & P1004 (60\%), P1096 (53\%), \\
& P1080 (38\%), MO (56\%), \\
& DD (23\%), PE (22\%), \\
& P383 (28\%), P382 (15\%) \\
\hline $1950-2250 \mathrm{Ma}$ & P1080 (6\%), DD (13\%), \\
& PE (9\%), FMG (9\%), \\
& STPB (13\%), P383 (7\%), \\
& P382 (18\%) \\
\hline
\end{tabular}

The oldest age group, 1950-2250 Ma, is overall the least abundant and exists in all samples except P1004, 1096, and MO (Table 2). Overlaying the age populations in figure 24 are the age peaks that occur within the samples. The $\mathrm{U}-\mathrm{Pb}$ age peaks within a single sample often overlap with peaks in other samples likely indicating a similar provenance. The 
peaks between samples are identified as overlapping if they are within $5 \mathrm{Ma}$ of each other.

Figure 33 shows the various U-Pb age peaks from 200-800 Ma. The orange rectangles group together age peaks within $5 \mathrm{Ma}$ of each other. Between 200 and $500 \mathrm{Ma}$, samples P1004, P1096, P1080, OCS-G-6848, OCS-G-6406, and OCS-G-6396 have 12 correlatable peaks. However, samples OCS-G-2516, OSC-G-2523, P383, and P382 lack any correlative age peaks younger than $500 \mathrm{Ma}$. In fact, only one age peak at $493 \mathrm{Ma}$ from sample P382 is younger than $500 \mathrm{Ma}$. The youngest correlative age peaks are Triassic (201-202 Ma) and occur in the Destin Dome and Pensacola samples which lie within the Apalachicola Embayment. Other correlative peaks that occur between 250-500 Ma include 292-295 Ma (P1080, OCS-G-6848, and OCS-G6396), 325-328 Ma (P1080 and OCS-G-6848), 328-332 Ma (P1096 and P1080), 332-334 Ma

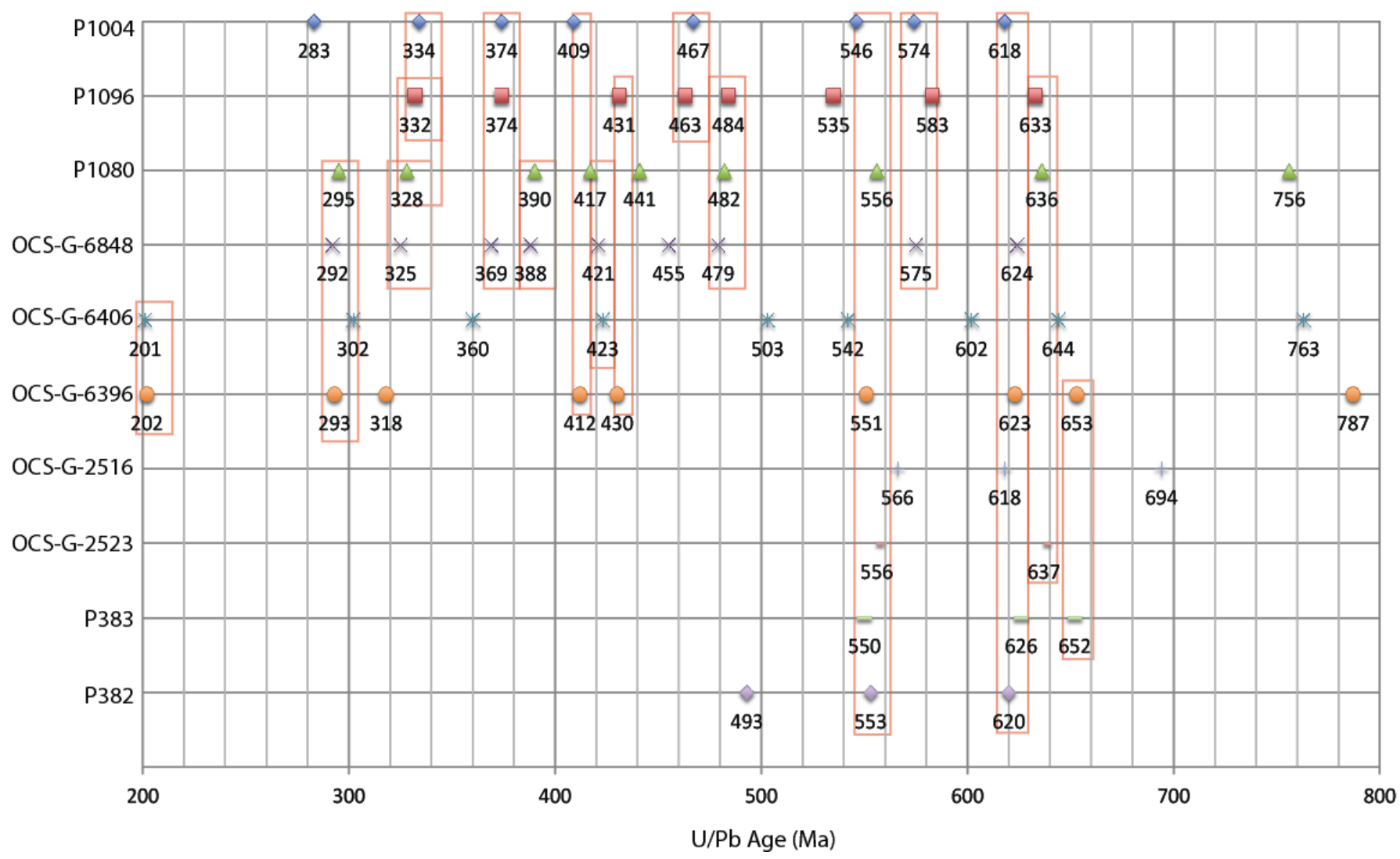

Figure 33. U-Pb age population peaks from 200-800 Ma that occur within the samples. Orange boxes show overlapping peaks within 5 Ma of each other that occur across samples. 
(P1004 and P1096), 369-374 Ma (P1004, P1096, and OCS-G-6848), 388-390 (P1080 and OCS-G6848), 409-412 Ma (P1004 and OCS-G-6396), 417-423 Ma (P1080, OCS-G-6846, and OCS-G6406), 430-431 Ma (P1096 and OCS-G-6396), 463-467 Ma (P1004 and P1096), and 479-484 Ma (P1096, P1080, and OCS-G-6848).

Several ages peaks within the 500-700 Ma age population are correlatable between samples. These include 546-556 Ma (P1004, P1080, OCS-G-6396, OCS-G-2523, P383, and P382), 574-575 Ma (P1004 and OCS-G-6848), 618-626 Ma (P1004, OCS-G-6848, OCS-G-6396, OCS-G2516, P383, and P382), 633-637 Ma (P1096, P1080, and OCS-G-2523), and 652-653 Ma (OCS-G6396 and P383). The age peaks with the greatest number of correlative samples are 546-556 Ma and 618-626 Ma which each contain six samples.

The age population 900-1400 Ma contains eight correlatable age peaks (Fig. 34). These include 1011-1013 Ma (P1096, OCS-G-6848, and P383), 1030-1031 Ma (P1080 and OCSG-6396, 1060-1065 Ma (P1004 and OCS-G-6848), 1152-1154 Ma (P1096 and OCS-G-6848), 1177 Ma (P1004 and OCS-G-6404), 1221-1223 Ma (OCS-G-6396 and OCS-G-2523), 1315-1320 Ma (P1004, P1096, and P1080), and 1350-1352 Ma (OCS-G-2523 and P382).

The oldest age population 1950-2250 Ma contains nine correlatable age peaks (Fig. 35). These include 1988-1990 Ma (P383 and P382), 2032-2037 Ma (OCS-G-6396 and OCS-G-2516), 2050 Ma (OCS-G-6406 and P383), 2088-2092 Ma (OCS-G-6848 and OCS-G-6396), 2092-2095 Ma (OCS-G-6406, OCS-G-6396, P382), 2121-2125 Ma (P1004, P1080, OCS-G-6406, OCS-G-2516, and P382), 2133-2134 Ma (P1096 and P383), 2188-2192 Ma (OCS-G-6396 and P382), and $2218 \mathrm{Ma}$ (OCS-G-2523 and P382). The age peak at 2121-2125 Ma has the greatest abundance of 


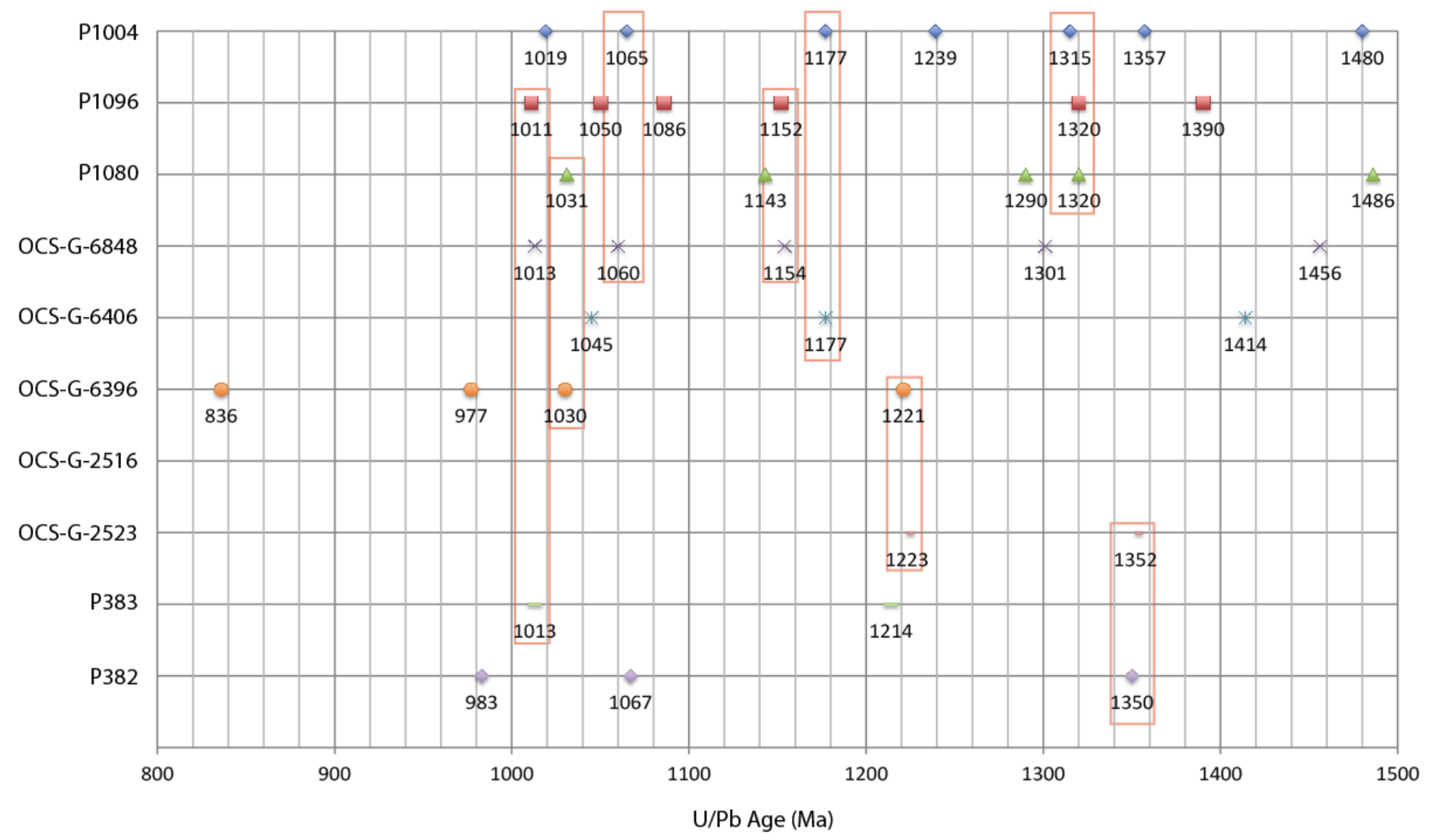

Figure 34. U-Pb age population peaks from 800-1500 Ma that occur within the samples. Orange boxes show overlapping peaks within 5 Ma of each other that occur across samples.

correlative samples with five samples containing this age peak that span the Florida Panhandle,

Destin Dome, Florida Middle Ground, and offshore Florida peninsula samples.

Other correlatable age peaks that occur outside of the major age populations include

1616-1620 Ma (P1096 and OCS-G-6406); 1881-1889 Ma (P1096, P1080, OCS-G-6396, P383, and

P382), 2443-2445 Ma (OCS-G-6406 and P383), and 2766-2770 Ma (OCS-G-6396 and OCS-G-

2523). The 1881-1889 Ma age peak occurs in five samples which include P1096, P1080,

Pensacola, and offshore Florida peninsula. 


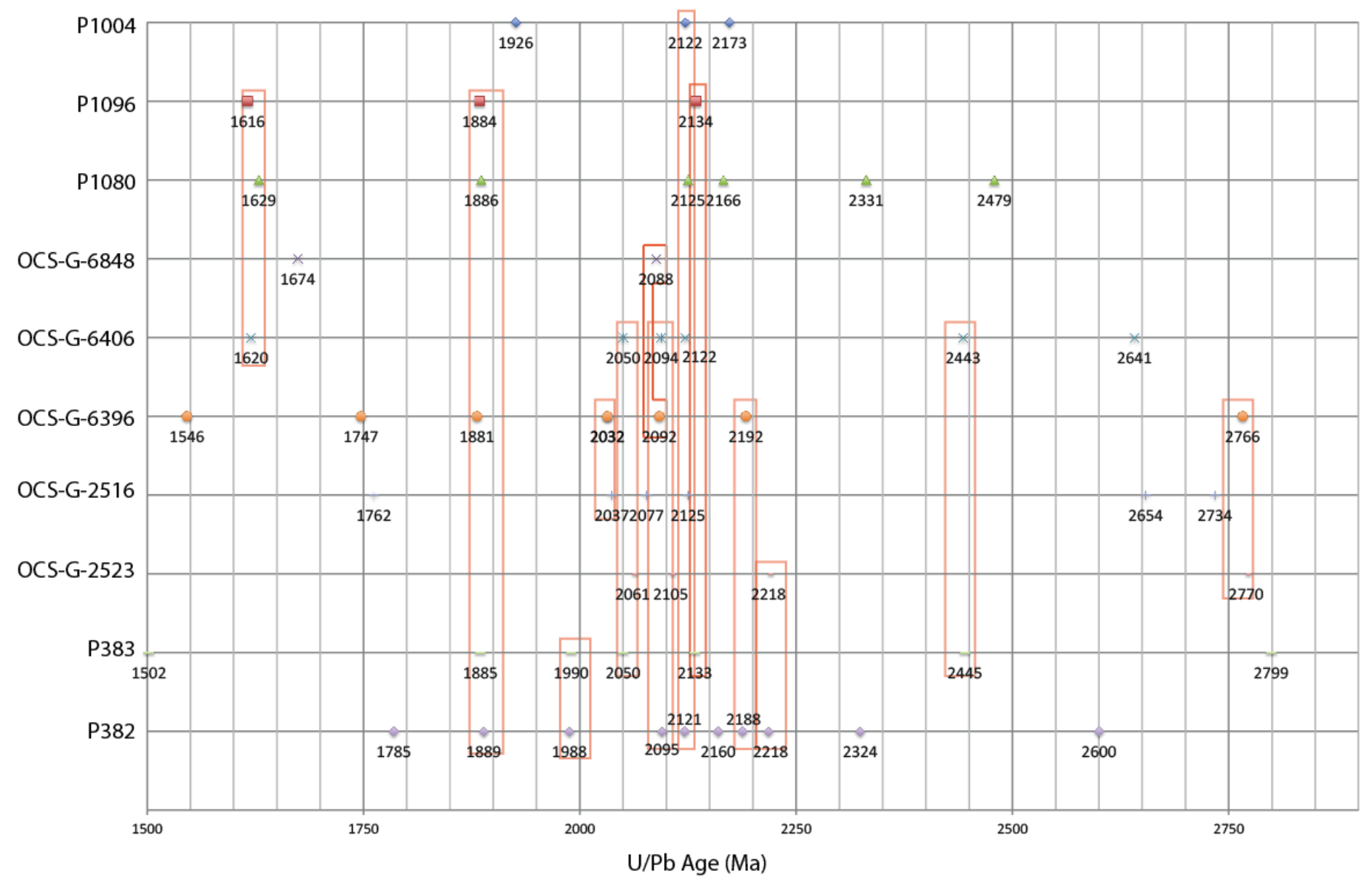

Figure 35. U-Pb age population peaks from 1500-2900 Ma that occur within the samples. Orange boxes show overlapping peaks within 5 Ma of each other that occur across samples.

\subsection{Metamorphic Zircon Populations}

Several metamorphic zircon age populations were identified based on U/Th ratios of zircon greater than four (Fig. 36). However, the overall metamorphic population is small accounting for a total of 63 out of the 867 grains from all ten samples. Sample P1004 had a single metamorphic zircon at $411 \mathrm{Ma}$ and $1913 \mathrm{Ma}$ as well as a group of metamorphic zircon between $989 \mathrm{Ma}$ and $1256 \mathrm{Ma}$. Sample P1096 similarly has a group of metamorphic zircon ages between $1010 \mathrm{Ma}$ and $1157 \mathrm{Ma}$ but also a group at 375-377 Ma. Single metamorphic zircons occur at $629 \mathrm{Ma}$ and $1310 \mathrm{Ma}$. Sample P1080 has one group of metamorphic zircons 
between $327 \mathrm{Ma}$ and $457 \mathrm{Ma}$ and a single metamorphic zircon at $584 \mathrm{Ma}$. Sample OCS-G-6848 from Mobile Bay has two populations of metamorphic zircon at 390-439 Ma and 978-1189 Ma. The Destin Dome sample OCS-G-6406 has two groups of metamorphic zircons that occur at 533-615 Ma and 2050-2093 Ma. Single metamorphic zircons occur at $767 \mathrm{Ma}, 1006 \mathrm{Ma}, 1179$ Ma, and $2443 \mathrm{Ma}$.

The Pensacola sample, OCS-G-6396, has only two single metamorphic zircon at $1031 \mathrm{Ma}$ and $561 \mathrm{Ma}$. The sample from the Florida Middle Ground, OCS-G-2516, has two metamorphic zircon populations at 567-623 Ma and 2038-2084 Ma. It also has two single metamorphic zircons at $1066 \mathrm{Ma}$ and $2735 \mathrm{Ma}$. Sample OCS-G-2523 from St. Petersburg has one metamorphic zircon population from 529-645 Ma and a single metamorphic zircon at 2063 Ma. Sample P382 from offshore Florida has three single metamorphic zircon at $633 \mathrm{Ma}, 1392 \mathrm{Ma}$, and 2067 Ma. The other offshore Florida sample, P383, has a single metamorphic zircon at $1035 \mathrm{Ma}$ and a metamorphic population from 526-550 Ma. 

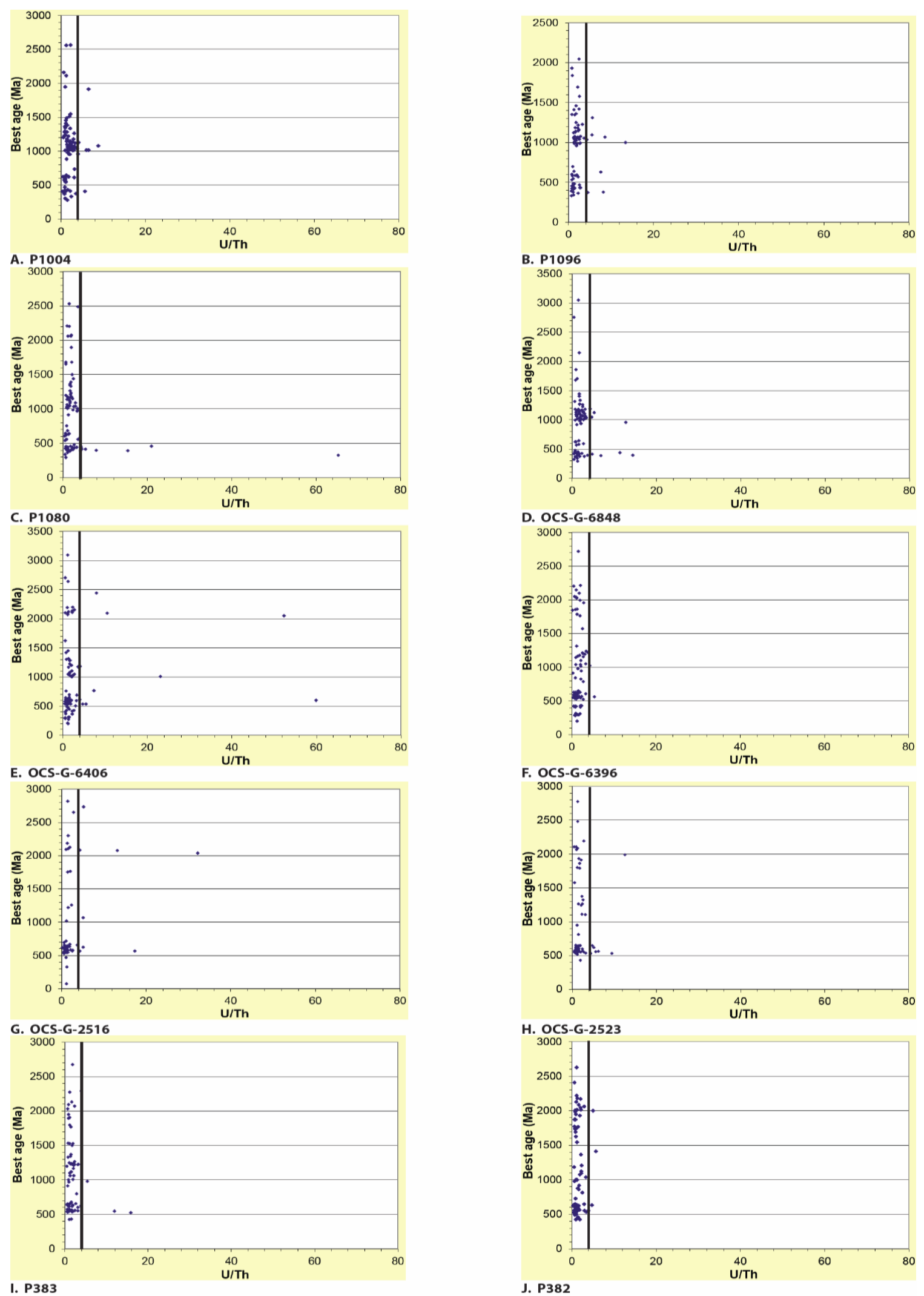

Figure 36. U-Pb age vs. U/Th plots. Black line indicates a U/Th ratio of 4 . A ratio greater than 4 indicates a metamorphic zircon. 
Several samples share similar metamorphic zircon populations. Four distinct metamorphic populations occur throughout the samples. The youngest metamorphic zircon population is between 327-460 Ma and includes P1004, P1096, P1080, and OCS-G-6848. Samples P1096, P1080, OCS-G-6406, OCS-G-6396, OCS-G-2516, OCS-G-2523, P382, and P383 share a population between 526-645 Ma. Samples P1004, P1096, OCS-G-6848, OCS-G-6406, OCS-G-6396, OCS-G-2516, and P383 share metamorphic zircons from 978-1256 Ma. The oldest metamorphic zircon population occurs from 2038-2093 Ma and includes samples OCS-G-6406, OCS-G-2516, OCS-G-2523, and P382 (Fig. 37).

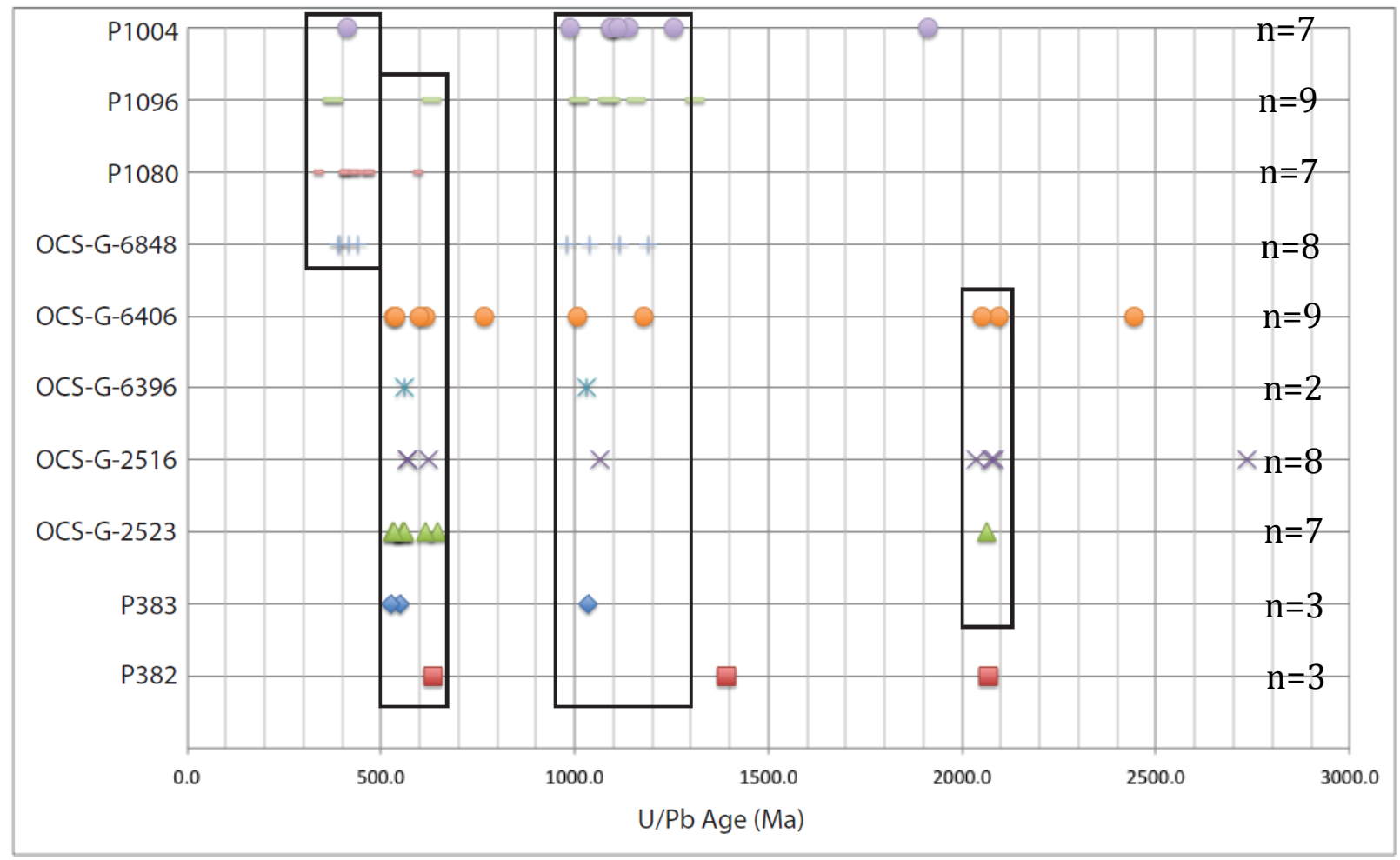

Figure 37. Ages of metamorphic zircons for all samples. Boxes group metamorphic zircons into age populations (300-500 Ma, 500-680 Ma, 950-1300 Ma, and 2000-2125 Ma). 


\subsection{Regions of Similar U-Pb Age Distribution}

Samples are grouped based on similarity in grain age abundances, age peaks, and metamorphic zircon populations. From these attributes, four groups were identified, the Florida Panhandle samples, Mobile Bay sample, Apalachicola Embayment samples, and the southeastern GOM samples. Figure 38 shows the spatial distribution of the wells with similar age distribution.

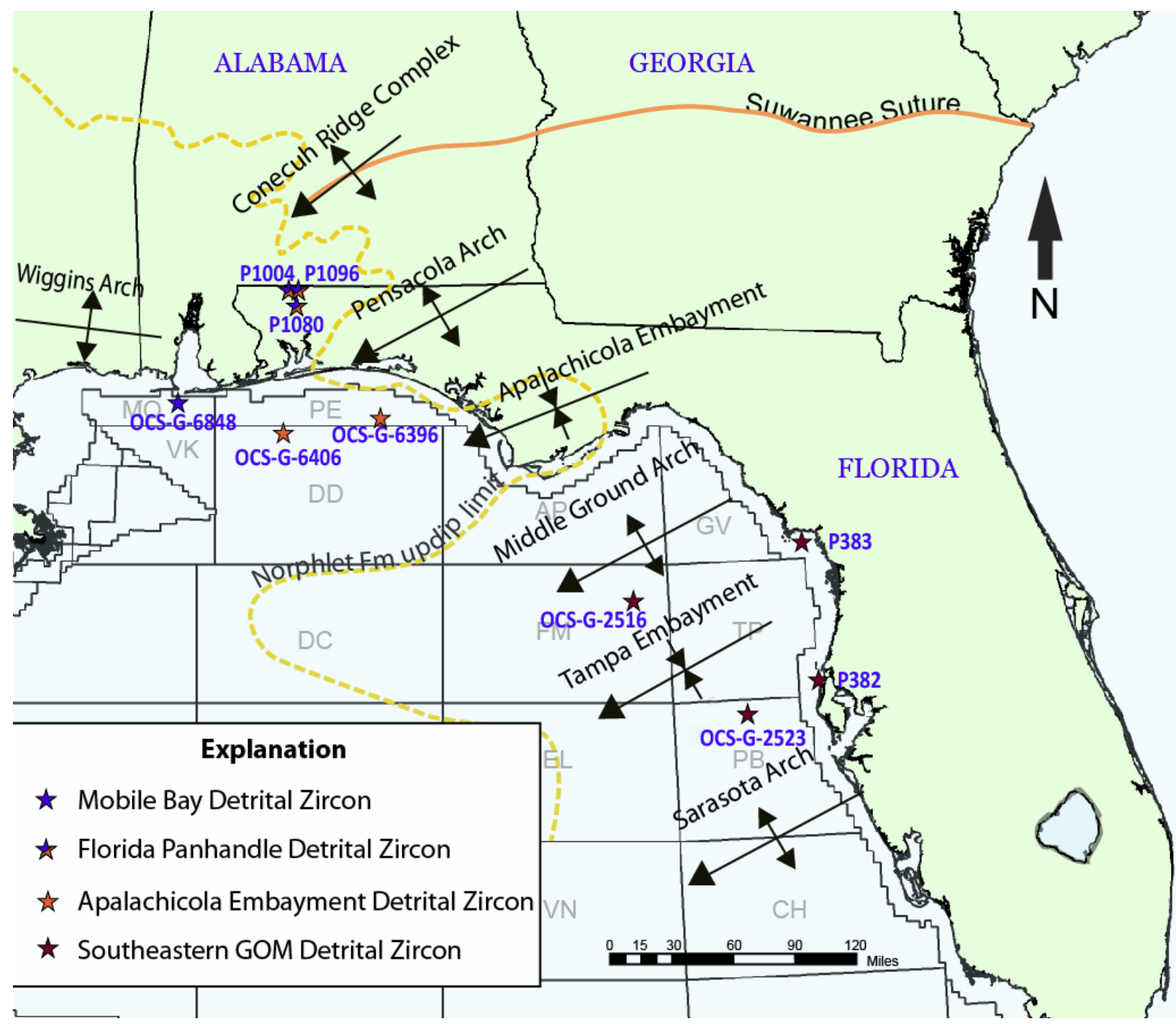

Figure 38. Samples with similar detrital zircon U-Pb age distributions. Four areas were identified including those in the Florida Panhandle (blue/purple), Mobile Bay (blue), Apalachicola Embayment (purple), and southeastern Gulf of Mexico (red). 


\subsubsection{Florida Panhandle}

The U-Pb ages from the Florida Panhandle samples (P1004, P1096, and P1080) all share similar characteristics. The majority of all zircon ages fall between $250-650 \mathrm{Ma}(26-45 \%)$ and 900-1550 Ma (40-66\%). The samples also share similar zircon abundances between 500-700 Ma (11-15\%) as well as between 1900-2250 Ma (0-1\%). Samples P1004 and P1080 share peaks at $374 \mathrm{Ma}$ and 463-467 Ma. Samples P1096 and P1080 share peaks at $633 \mathrm{Ma}$ and 1884-1886 Ma. Samples P1004 and P1080 share an age peak at 2122-2125 Ma. All samples share an age peak at 1315-1320 Ma. These samples also share metamorphic zircon populations between 300-500 Ma and P1004 and P1096 share metamorphic zircons between 950-1300 Ma.

\subsubsection{Mobile Bay}

Well OCS-G-6848 differs from many of the other samples due to the large amount of grains within 900-1400 Ma (56\%) and small abundance of grains between 500-700 Ma (7\%) and 1900-2250 Ma (1\%). However, this sample shares several of its major age peaks with other samples, predominantly those from the Florida Panhandle. These include: 367-374 Ma with P1004 and P1096, 417-423 Ma with P1080 and OCS-G-6406, 1011-1013 Ma with P1096 and OCS-G-2523, and 1152-1154 Ma with P1096. This sample also shares a metamorphic zircon population with the Florida Panhandle wells between 300-500 Ma as well as between 950-1300 Ma.

\subsubsection{Apalachicola Embayment}

Zircon age populations are also similar for wells OCS-G-6406 and OCS-G-6396. These two wells have the youngest aged zircons (3 grains) with a shared peak at 201-202 Ma. They also have a larger abundance of grains between 500-700 Ma (33-37\%) than the previously 
mentioned samples. These two samples only share one age peak (2092-2094 Ma) but share three metamorphic zircon age populations, 500-700 Ma, 950-1300 Ma, and 2000-2150 Ma.

\subsubsection{Southeastern Gulf of Mexico}

The southeastern samples are the wells that do not contain Norphlet but contain collectively the Jurassic Cotton Valley Group, Haynesville Formation, and the Paleozoic basement. These samples are also drastically different from the previous samples and quite similar to each other. The greatest abundances of grains for these samples occur between 500$700 \mathrm{Ma}$ (45-72\%). Within this range, samples OCS-G-2523, P383, and P382 share the 550-551 age peak and OCS-G-2516, P383, and P382 share the 618-626 age peak. These samples also share a smaller age population between 1900-2250 Ma (7-20\%). Shared metamorphic zircon populations include 500-700 Ma and 2000-2150 Ma.

\subsection{Grain Size Analysis}

The result of Evan Knight's detrital zircon grain size analysis showed little correlation between a particular grain size and U-Pb age. Figure 39 shows the results of this work with histograms of grain size distribution for each sample and age vs. grain size plots for each sample. The highlighted section on the age vs. grain size plot is meant to represent the Grenville mountain building event (900-1400 Ma). It has been speculated that Grenville-aged zircons are generally larger, however, this analysis does not show a correlation.

Similarities seen in the various samples include the Florida Panhandle wells (P1004, P1096, and P1080) which have similar tri-modal zircon size distributions and zircon grain-size range. Samples OCS-G-6406 (DD) and OCS-G-6396 (PE) also have similar bimodal distributions 
with two peaks occurring at 15 and 17-18 mm. Sample OCS-G-2516 (FMG) and P382 both have a uni-modal distribution and have a smaller overall grains size (mean of $10-11 \mathrm{~mm}$ ).
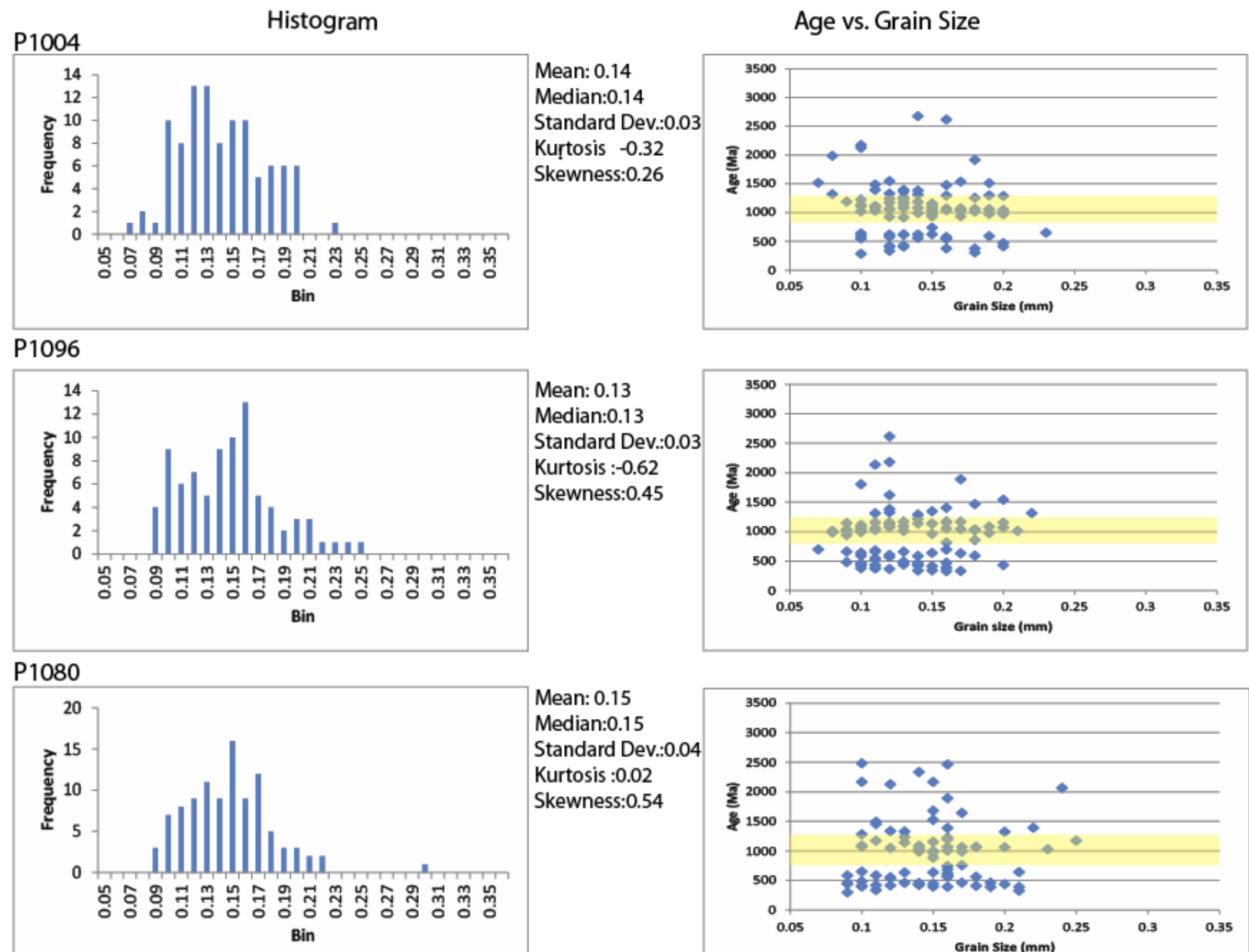

Mean: 0.15 Median:0.15 Standard Dev.:0.04 Kurtosis :0.02 Skewness:0.54

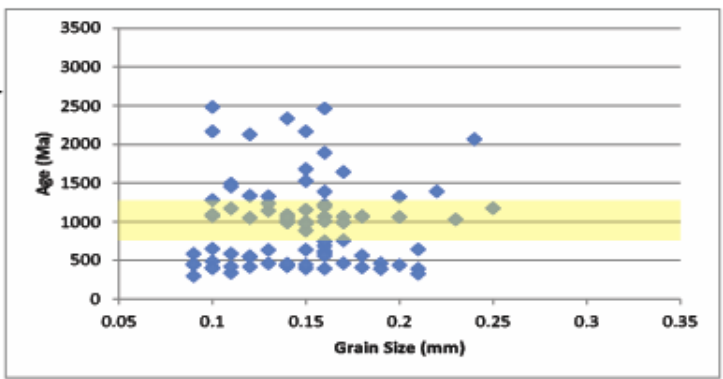

\section{OCS-G-6406}
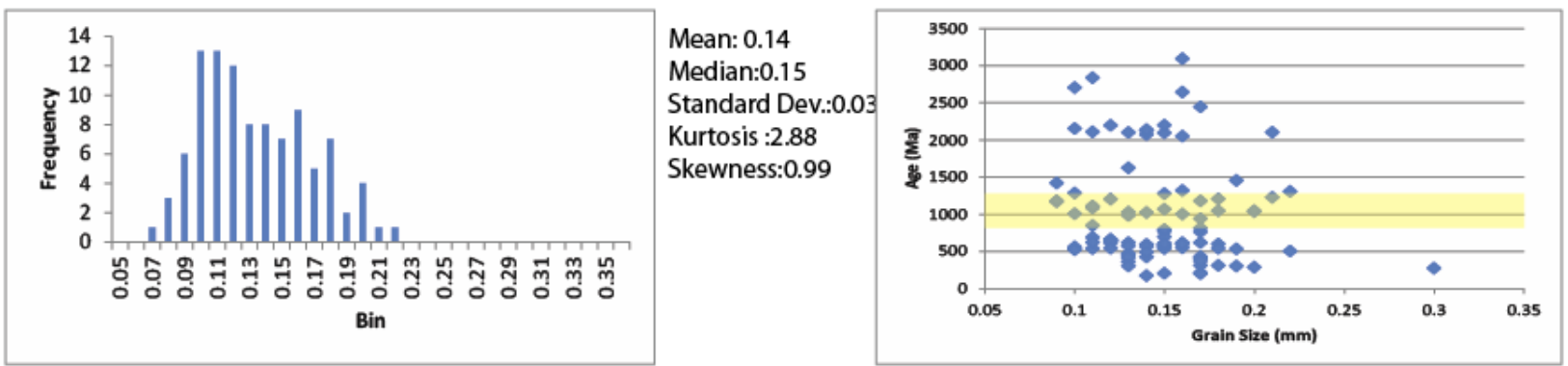


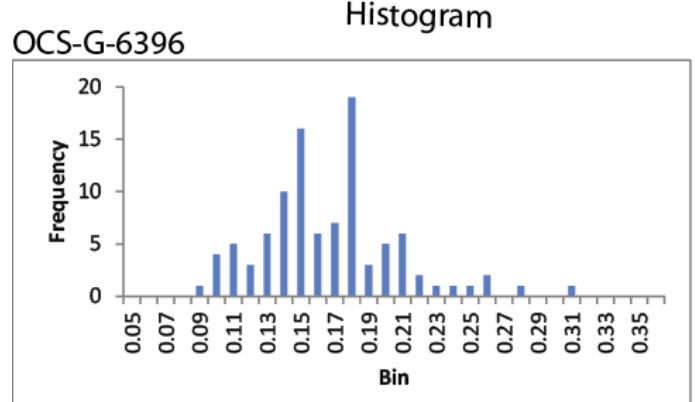

\section{OCS-G-2516}

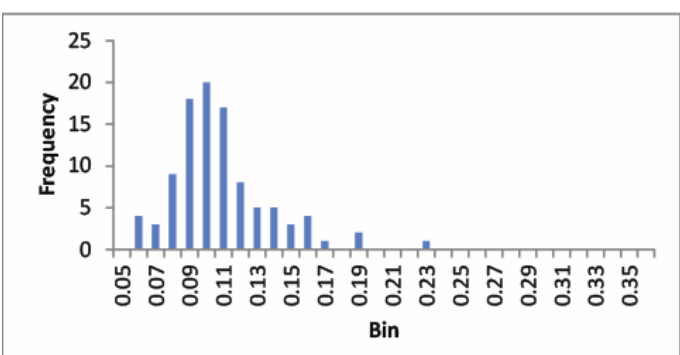

\section{OCS-G-2523}

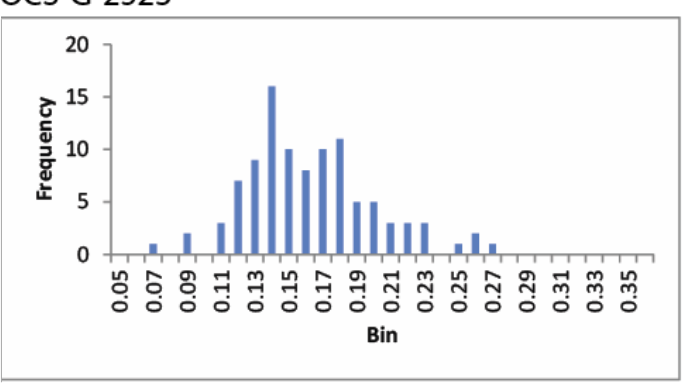

\section{P383}

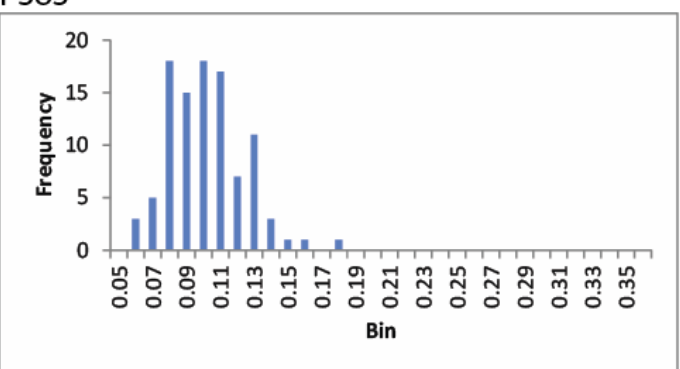

\section{P382}

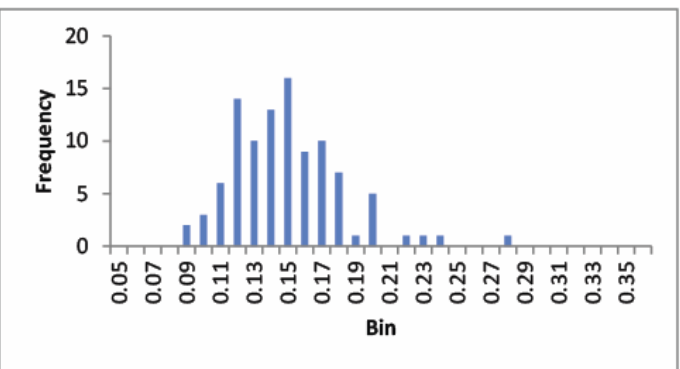

Age vs. Grain Size

Mean: 0.17

Median:0.16

Standard Dev.:0.04

Kurtosis :1.28

Skewness:0.78

Mean: 0.11

Median:0.10

Standard Dev.:0.03

Kurtosis :2.79

Skewness:1.29

Mean: 0.15

Median:0.15

Standard Dev.:0.03

Kurtosis : 2.22

Skewness:1.03
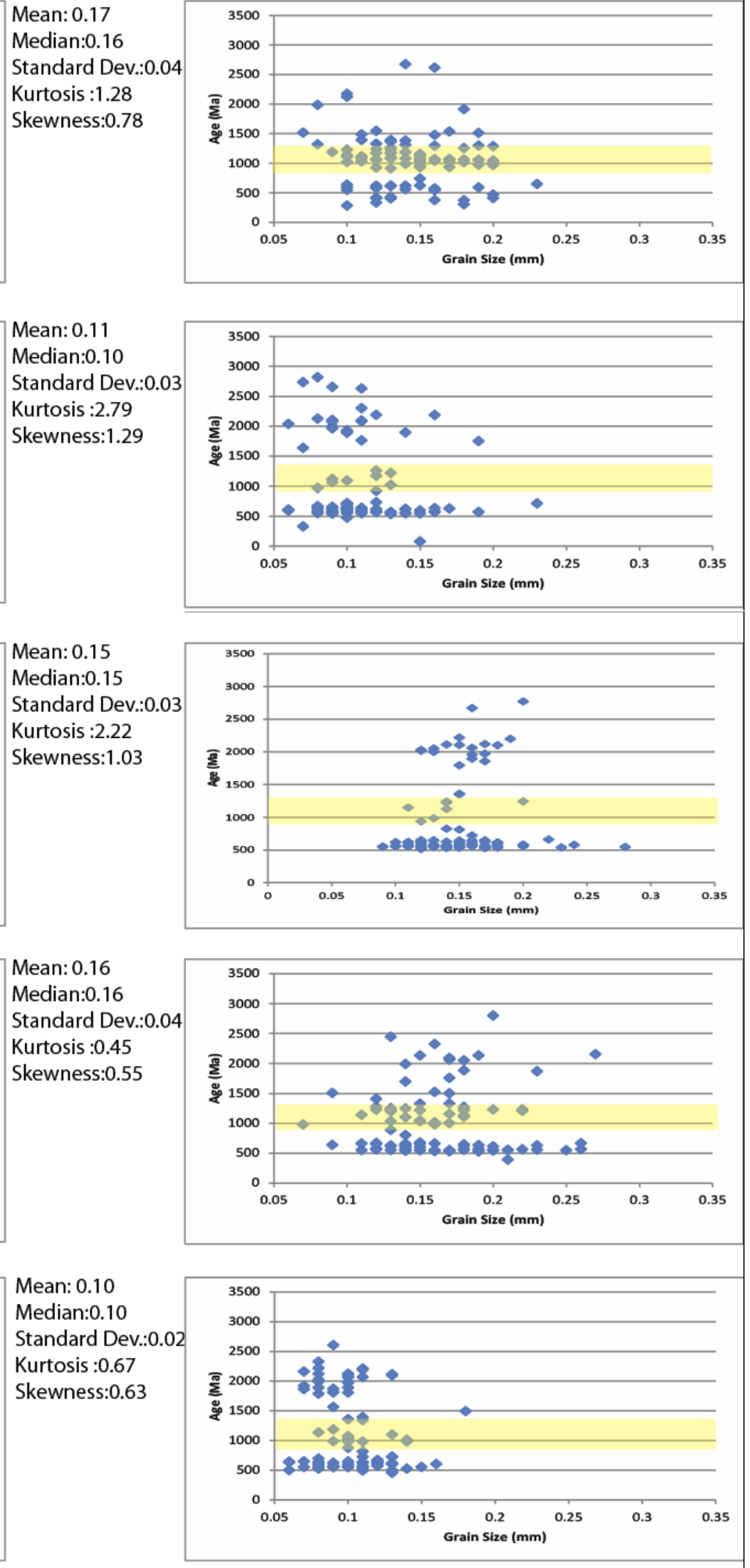

Figure 39. Detrital zircon grain size analysis. Histogram of grain sizes for each sample is on the left. Age vs. grain size plots are on the right. Yellow area highlights the Grenville-age zircon population (900-1400 Ma) which illustrates the low correlation of the Grenville event to a specific size. 


\subsection{Norphlet Sandstone Composition}

The results from point counting eleven thin-sections from five wells shows a range of sandstone compositions that include subarkose, arkose, and lithic arkose (Fig. 40; Folk, 1980). Subarkose is the most abundant sandstone composition which is represented by seven samples classified. Three samples are classified as arkose and only one sample is classified as lithic arkose. The framework grains identified in the eolian facies of the Norphlet Formation include quartz (monocrystalline, undulose and non-undulose, and polycrystalline), feldspar (orthoclase, un-twinned plagioclase, and twinned plagioclase), and lithic grain fragments (sedimentary, metamorphic, and volcanic; Fig. 41).

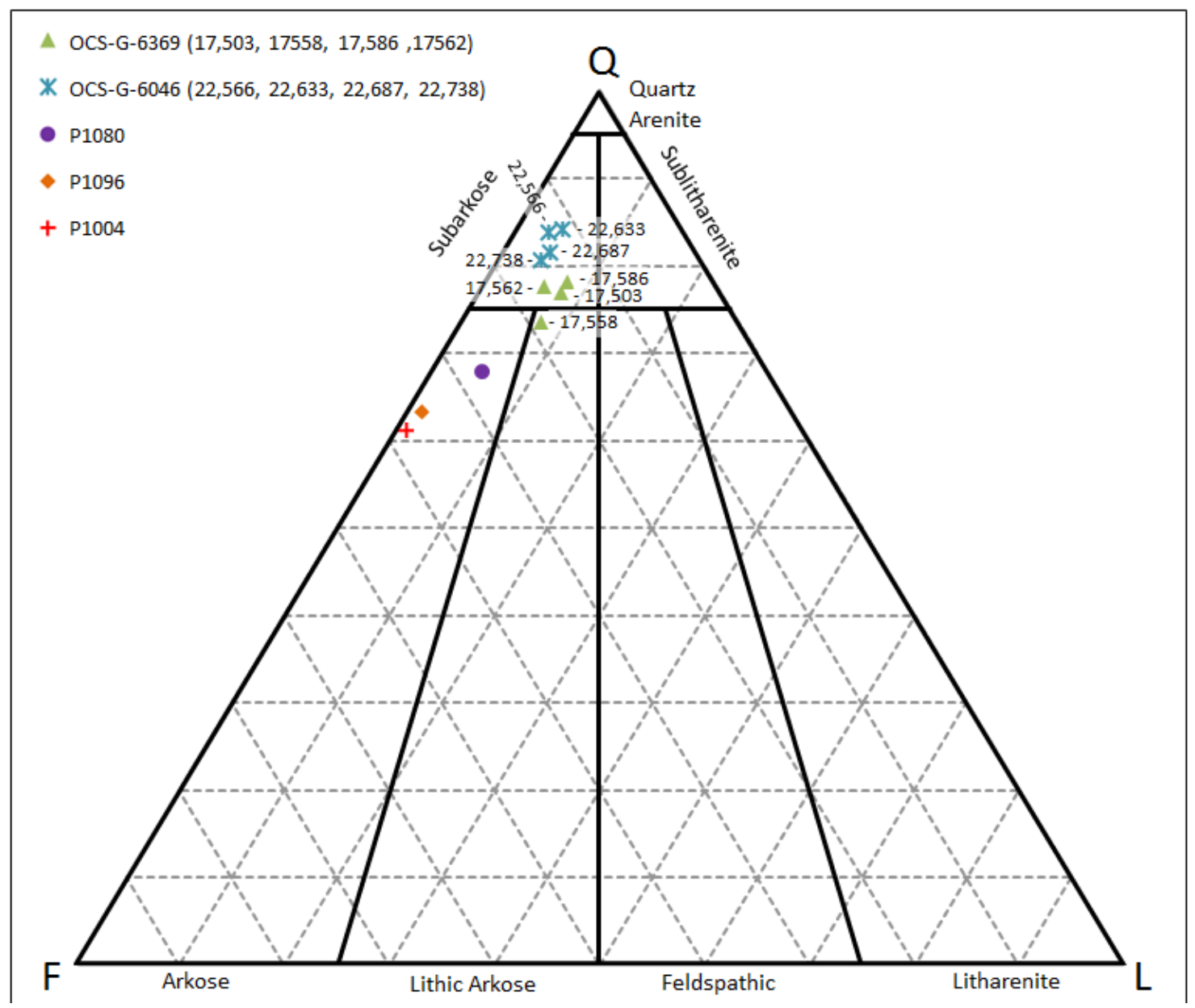

Figure 40. QFL plot of the eolian facies of the Norphlet Formation. Samples are predominantly subarkose with some arkose and one lithic arkose (Folk, 1980). 


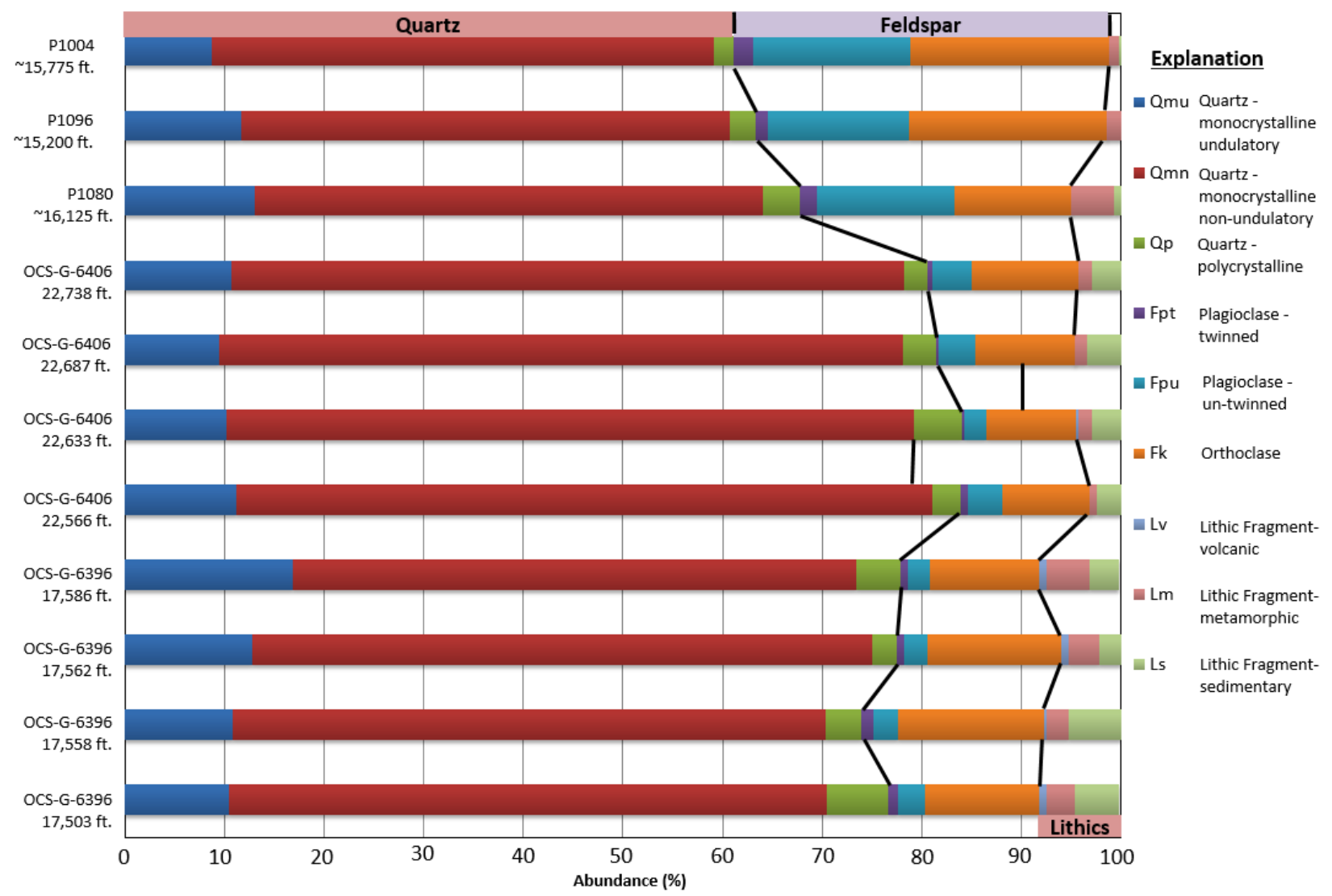

Figure 41. Relative abundances of framework grains for the eolian facies of the Norphlet Formation from modal analysis. Quartz grains include monocrystalline, undulatory (Qmu) and non-undulatory (Qmn), and polycrystalline (Qp). Feldspar grains include plagioclase, twinned (Fpt) and un-twinned (Fpu), and orthoclase (Fk). Lithic rock fragments include volcanic (Lv), metamorphic (Lm), and sedimentary (Ls). Exact depths for samples P1004, P1096, and P1080 are unknown but core chips throughout each sample interval remained lithologically similar.

The most abundant framework-grain type in the eolian facies of the Norphlet Formation is quartz and ranges from $61 \%$ (P1004) to $84 \%$ (OCS-G-6406). The most common type of quartz is monocrystalline with little to no undulatory extinction (Qmn) and it makes up 73\% (OCS-G6396 ) to $84 \%$ (OCS-G-6406) of the quartz grain population and averages $80 \%$. Several of the quartz grains are heavily vacuolized and contain mineral inclusions (Fig. 42 and 43). The second most common quartz type is undulatory, monocrystalline quartz (Qmu). This type ranges from $12 \%$ (OCS-G-6406) to $23 \%$ (OCS-G-6396) and averages $15 \%$. The least abundant quartz type is polycrystalline (Qp) which ranges from 3\% to $8 \%$ averaging $4.6 \%$. 
The second most abundant framework grain in the eolian facies is feldspar. Feldspars identified include orthoclase (Fk), un-twinned plagioclase (Fpu), and twinned plagioclase (Fpt). For the two wells in Destin Dome and Pensacolsa (OCS-G-6406 and OSC-G-6396), orthoclase is the most abundant feldspar ranging from 67\% (OSC-G-6406) to 81\% (OSC-G-6396) and averages 75\%. The second most common feldspar for the two samples is un-twinned plagioclase and varies from $14 \%$ (OCS-G-6396) to $27 \%$ (OCS-G-6046) averaging $20 \%$. The least abundant feldspar is twinned plagioclase which averages $5 \%$. For the three wells in the Florida Panhandle, the amount of orthoclase, averaging 51\%, is roughly equal to that of plagioclase, averaging $49 \%$. Of the plagioclase population, approximately $90 \%$ is made up of un-twinned plagioclase and $10 \%$ twinned plagioclase.

The third most abundant framework grains are lithic fragments and include sedimentary lithic fragments (Ls), metamorphic lithic fragments (Lm), and volcanic lithic fragments (Lv). Abundances of the three types of lithic fragments vary from well locations. The most common lithic fragment in the Destin Dome sample (OCS-G-6046) is sedimentary (silty mudstone) averaging $50 \%$ followed by metamorphic averaging $42 \%$. The least abundant is volcanic (plagioclase laths in a groundmass) averaging 9\%. The Pensacola sample (OCS-G-6396) has similar types of lithic clasts as the Destin Dome sample and is predominantly sedimentary lithic averaging $72 \%$ of the lithic population. The metamorphic lithics average $27 \%$ while the volcanics only represent $1 \%$. The most abundant lithic grain in the Florida Panhandle is metamorphic and averages $88 \%$. The dominant type of metamorphic rock fragment found in 

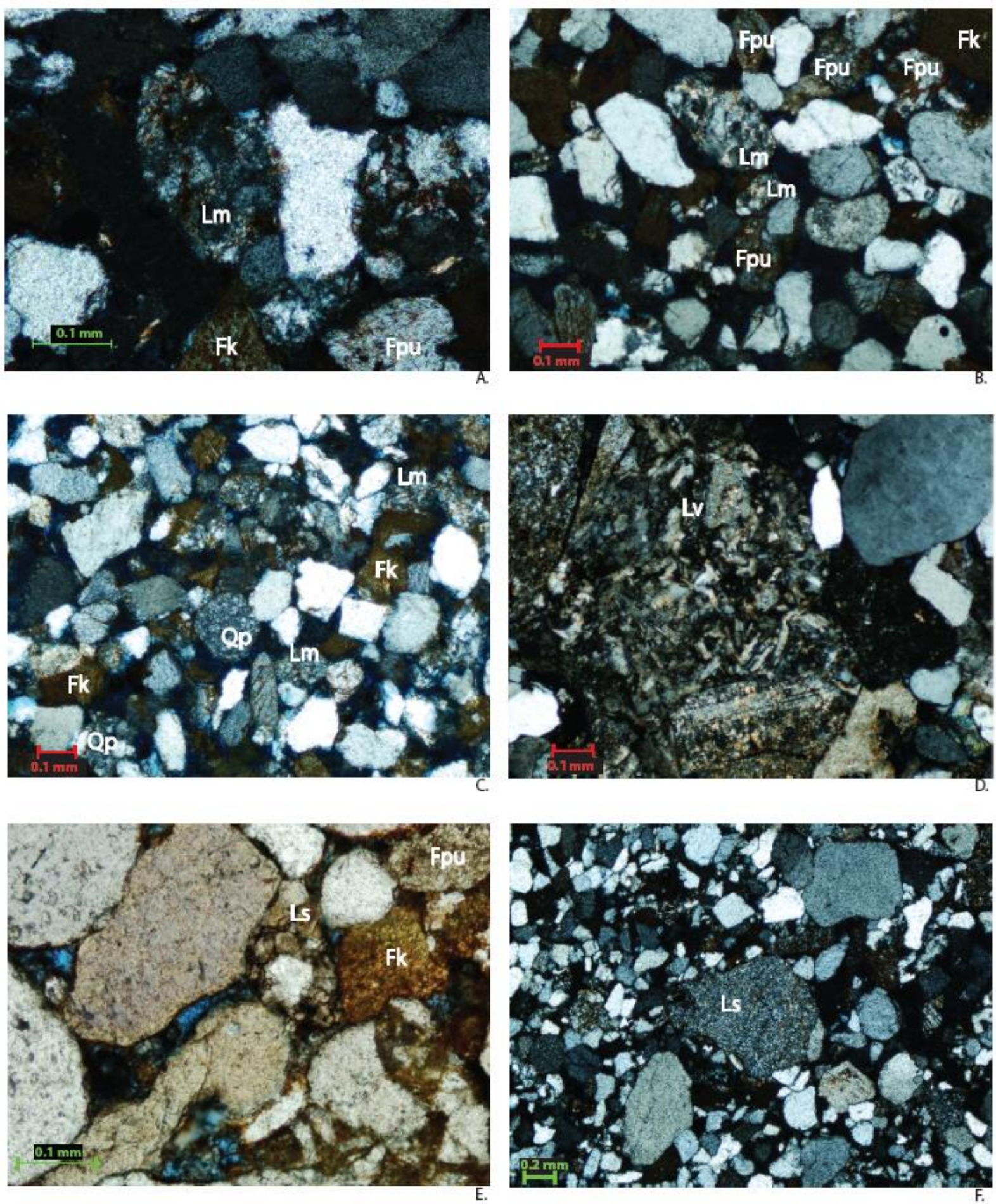

Figure 42. Framework grains in transmitted plane crossed-polarizer light (except E). All thin sections were stained for plagioclase (tinted pink) and orthoclase (tinted yellowish-brown). A) Metamorphic rock fragment surrounded by quartz, plagioclase, and orthoclase (P1004). B) Metamorphic rock fragment surrounded by quartz, plagioclase, and orthoclase (P1080). C) Polycrystalline quartz and metamorphic rock fragments surrounded by quartz, plagioclase, and orthoclase (P1096). D) Volcanic rock fragment of plagioclase laths in a fine grained matrix (OCS-G-6396-17,503 ft). E) Sedimentary rock fragment surrounded by quartz and orthoclase in plane polarized light (OCS-G-6406-22,687 ft). F) Silty mudstone lithic fragment (OCS-G-6396-17,503 ft). 
the Florida Panhandle consists of quartz with minor amounts of aligned phyllosilicate minerals (Fig. 42A and 42B). The sedimentary lithics in the Florida wells average $12 \%$ and there is no evidence of any volcanic lithics.

A grain texture found in all thin-sections was heavily included quartz. While several different types of inclusion were observed such as feldspar, biotite, and rutile, the most common inclusion is zircon (Fig. 43). Distinct zircon grain boundaries are difficult to observe due to radiation damage however, the radiation damage creates a distinct distortion within the quartz grain. Another common texture includes the alteration of the feldspar grains, predominately sericitization and vacuolization. Alteration is much more common in the plagioclase grains than the orthoclase. In the three Florida samples, a common feldspar form consist of plagioclase rimmed with orthoclase. This is also observed in the Destin Dome and Pensacola samples but is far less prevalent with only a few orthoclase rimmed plagioclase grains. 


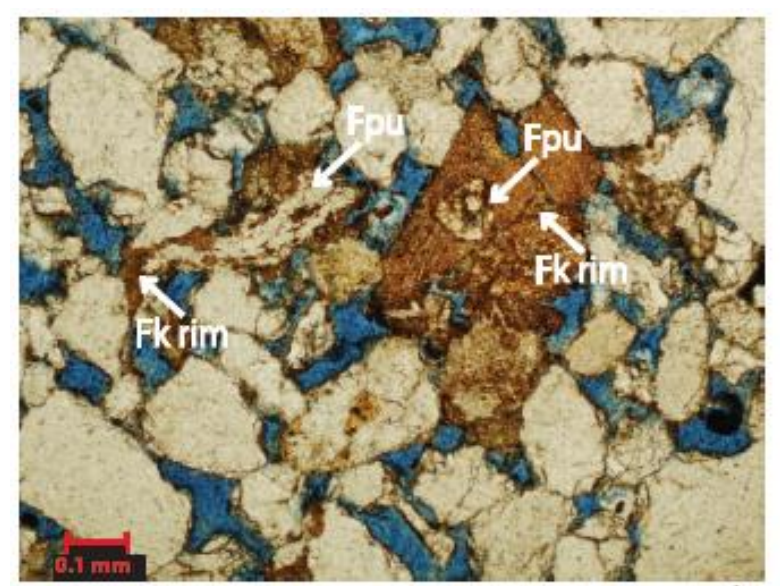

A.

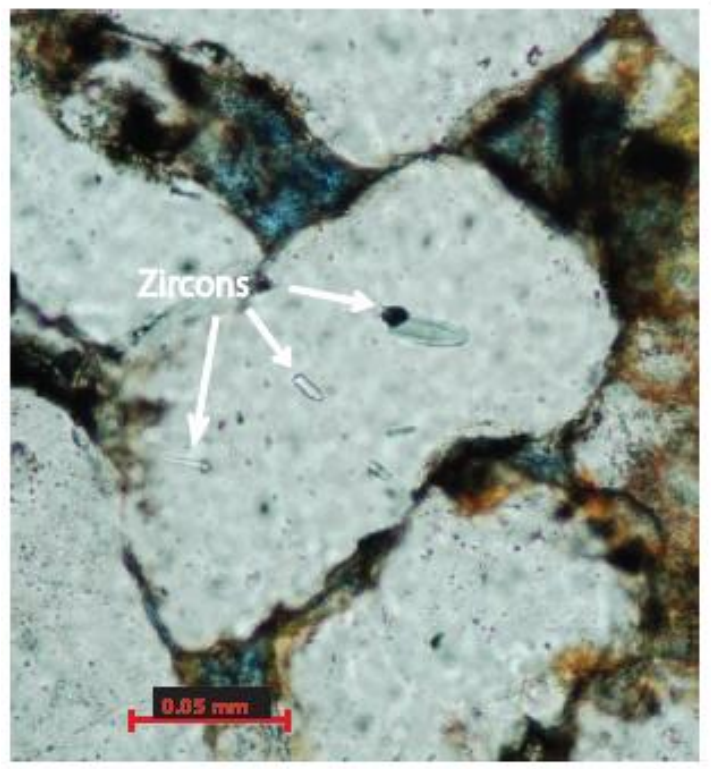

c.

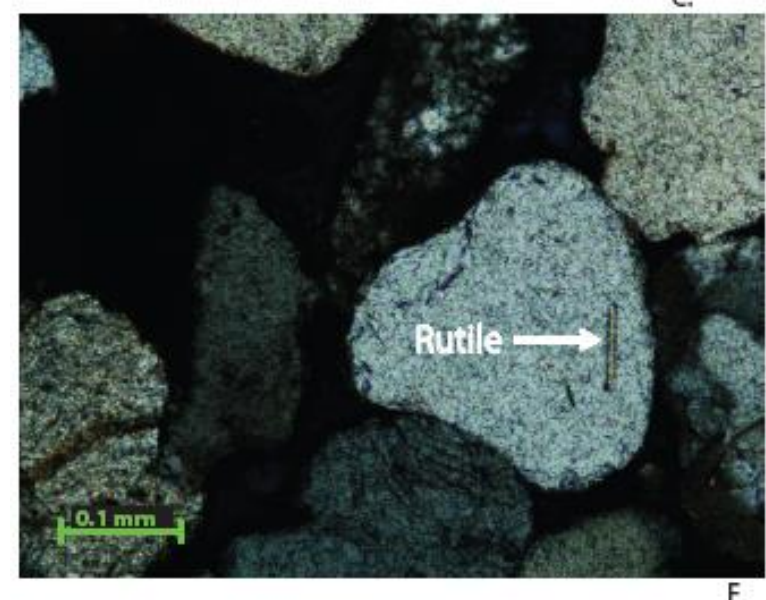

E.

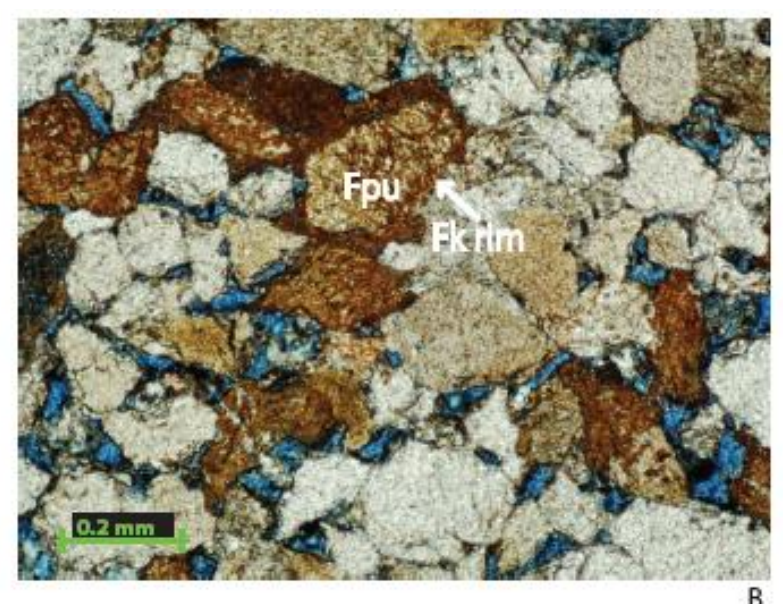

B.
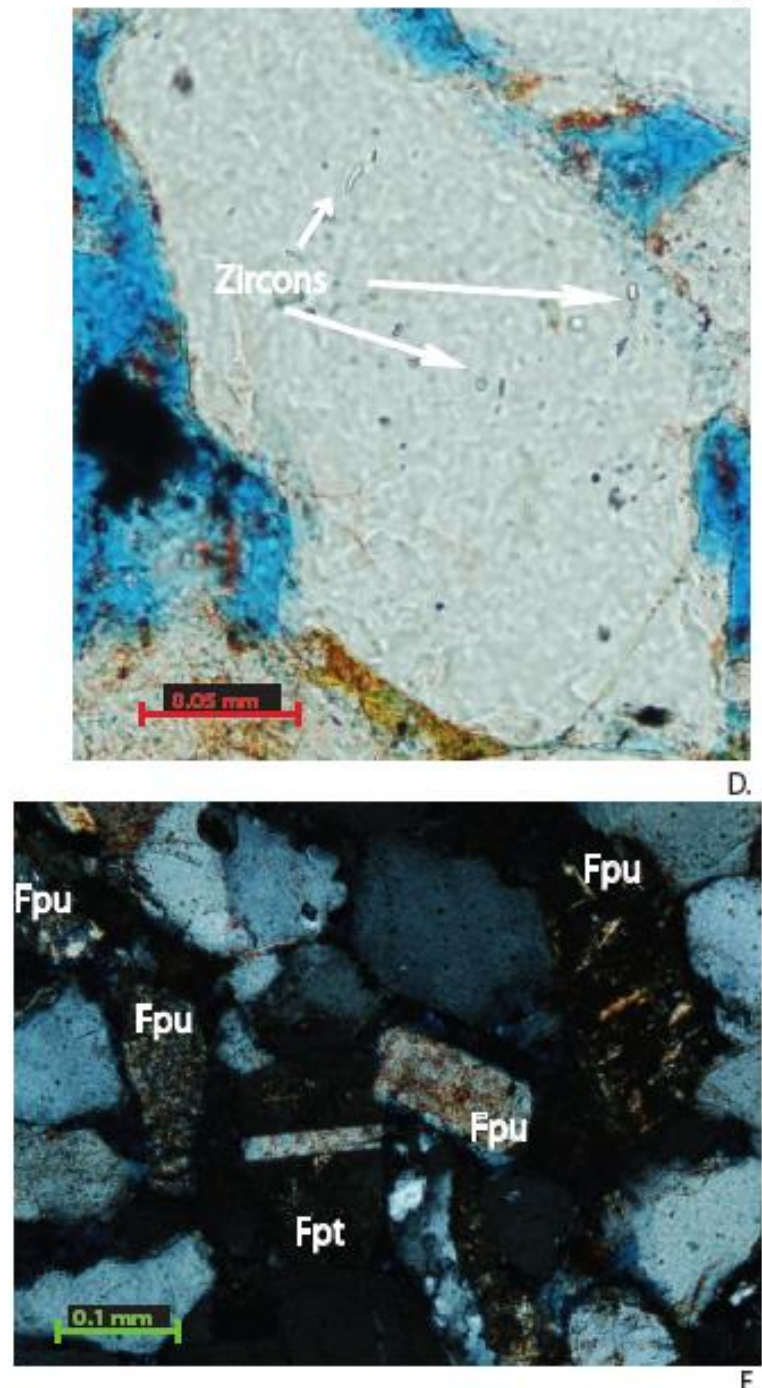

F.

Figure 43. Framework grains textures in thin-section. All thin-sections were stained for plagioclase (tinted pink) and orthoclase (tinted brown). A) Plagioclase grains with orthoclase rims in plane polarized light (PPL; P1080). B) Plagioclase grains with orthoclase rims in PPL (P1004). C) Quartz with zircon inclusions (OCS-G6406, 22,633 ft) in PPL. D) Quartz with zircon and other various minerals (P1096) in PPL. E) Quartz with rutile inclusion (OSC-G-6406, 22,633 ft) in cross-polarized light (XPL). F) Alteration of feldspar grains, predominantly sericitization (P1004) in XPL. 


\subsection{Dense Mineral Composition}

Dense minerals were counted for all ten samples. The results showed a range of heavy mineral abundances from predominantly phyllosilicate to mostly pyroxene and epidote (Fig.

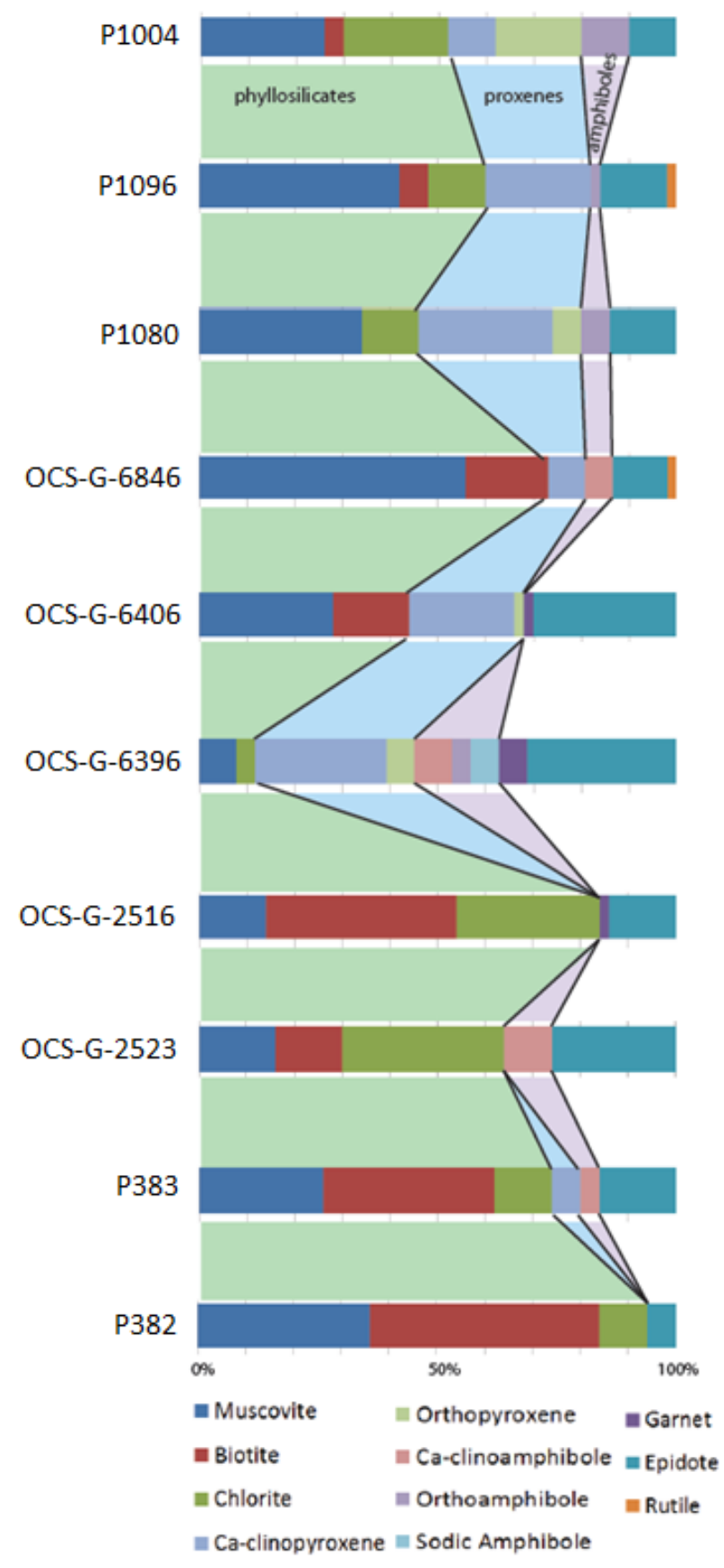

Figure 44. Abundances of dense minerals per sample.
44). Figure 45 shows examples of various heavy mineral identified in the samples.

The Florida Panhandle samples are fairly similar with regards to phylosilicates, pyroxenes, amphiboles, and epidote.

Phyllosilicates make up $46-60 \%$ (26-42\% muscovite, $0-6 \%$ biotite, and $12-22 \%$ chlorite). The ca-clinopyroxenes in these samples (augite and aegirine-augite) range from 10 to $28 \%$.

Orthopyroxene is missing from well P1096 but ranges from 6-18\% in P1080 and P1004, respectively. The epidote in the Florida Panhandle samples range from $10-14 \%$.

The Mobile Bay well (OCS-G-6848) is mostly phyllosilicates (73\%) with $58 \%$ muscovite and $17 \%$ biotite. The only pyroxene present is caclinopyroxene (augite and aegirine-augite) which makes up $8 \%$ and the only amphibole 
present is hornblende making up $6 \%$. Epidote makes up $12 \%$ of the sample and rutile makes up the last $2 \%$.

Sample OCS-G-6406 from Destin Dome consists of $44 \%$ phyllosilicates ( $28 \%$ muscovite and $16 \%$ biotite). Epidote is the second must abundant dense mineral making up 30\%. The predominant chain-silicate is ca-clinopyroxene (aegirine-augite) at $22 \%$ while orthopyroxene makes up only $2 \%$. Garnet is also rare making up $2 \%$ of the heavy minerals.

Sample OCS-G-6396 varies from the other samples as it has the largest amount of chain silicates and epidote. The most abundant dense mineral is epidote (31\%). The second most abundant mineral is pyroxene where ca-clinopyroxene (aegirine-augite) makes up $27 \%$ and orthopyroxene makes up $6 \%$. The amphiboles in this sample make up $18 \% ; 8 \%$ hornblende, $4 \%$ orthoamphibole (anthophyllite-gederite), and 7\% sodic amphibole (glaucophane). This sample has the lowest abundance of phyllosilicates at $12 \%$ ( $8 \%$ muscovite and $4 \%$ chlorite). Garnet is the most abundant in this sample yet still rare making up only $6 \%$.

Samples OCS-G-2516, OCS-G-2523, P383, and P382 are similar as they all have large abundances of phyllosilicates at $64-94 \%$ (14-36\% muscovite, $14-48 \%$ biotite, and $10-30 \%$ chlorite). The second largest dense mineral abundance in these samples is epidote ranging from 6-26\%. Pyroxene and amphiboles make up a smaller portions of samples OCS-G-2523 (10\% hornblende) and P383 (6\% augite and augite-aegirine and 4\% hornblende). Sample OCSG-2516 has minor amounts of garnet making up $2 \%$. 

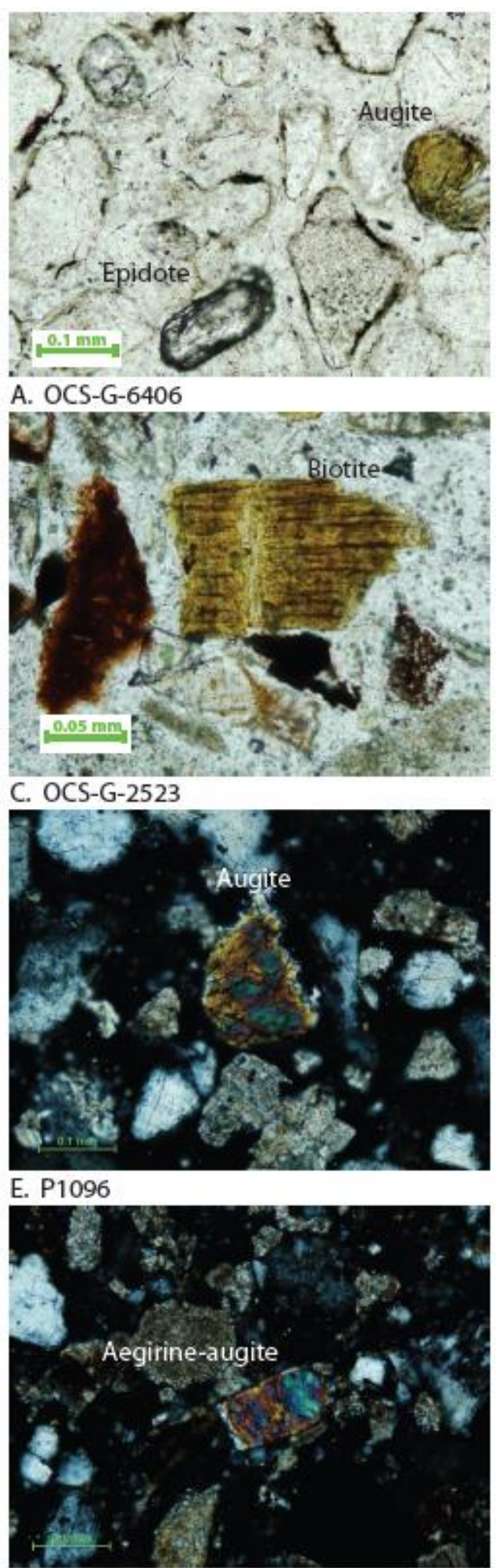

G. OCS-G-6848

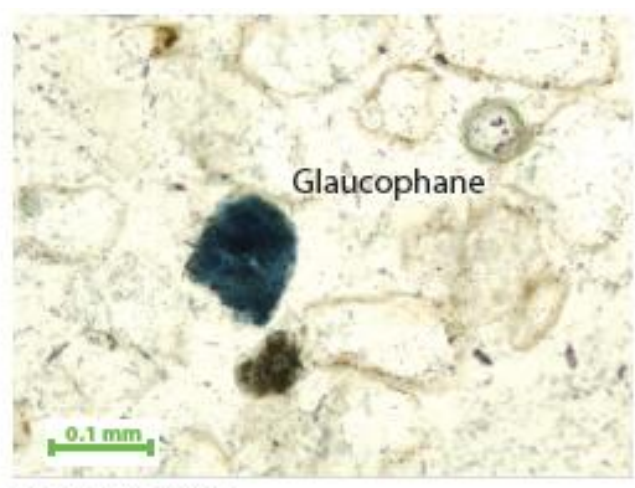

B. OCS-G-6396

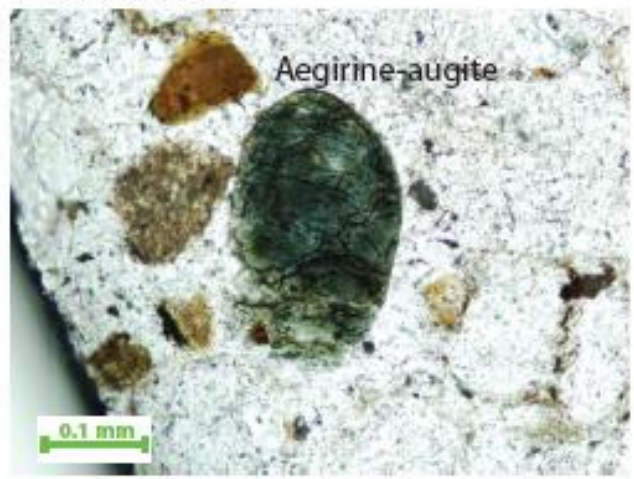

D. P383
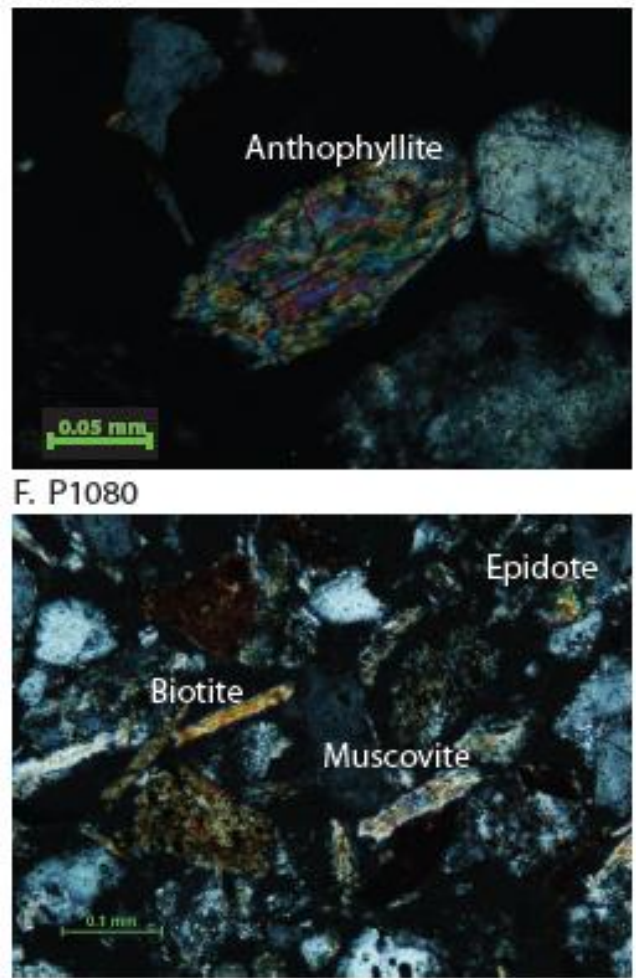

H. OCS-G-2516

Figure 45. Examples of dense minerals found within the samples. A) Augite and epidote detrital grains in sample OCS-G-6406 (PPL). B) Glaucophane in sample OCS-G-6396 (PPL). C) Biotite in sample OCS-G-2523 (PPL). D) Aegirine-augite in sample P383 (PPL). E) Augite in sample P1096 (XPL). F) Anthophyllite in sample P1080 (XPL). G) Aegirine-augite in sample OCS-G-6848 (XPL). H) Biotite, muscovite, and epidote in sample 0CS-G-2516 (XPL). 


\subsection{Well Log Analysis}

Log analysis was done using GeoGraphix 10.2 with 32 wells that drilled into the Norphlet

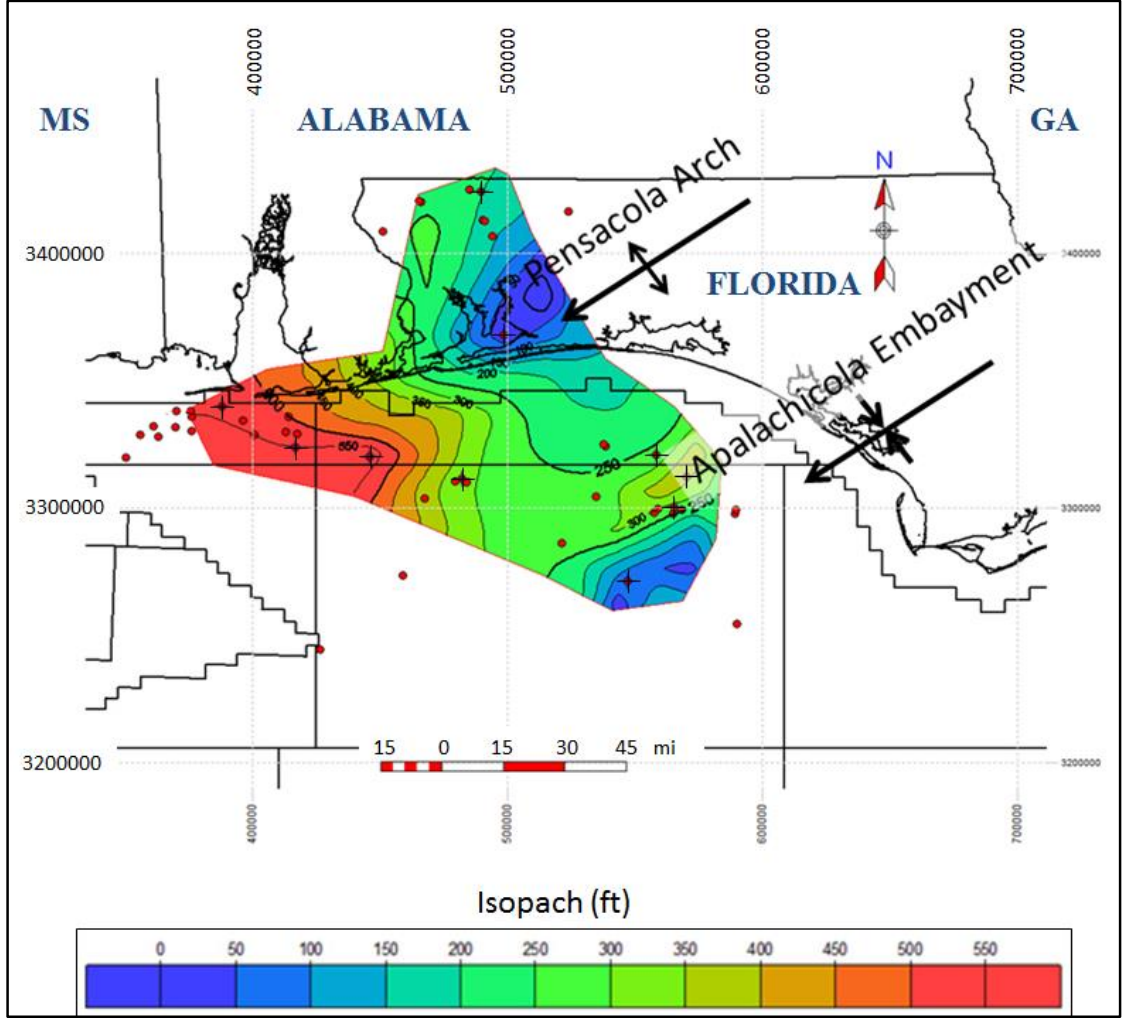

Figure 46. Isopach map of the Norphlet Formation (10 wells used, marked with cross symbol).
Formation from the Florida

Panhandle and offshore

federal lease blocks Destin

Dome, Pensacola, and

Mobile Bay. Figure 46 is an isopach map of the

Norphlet Formation in this area. Unfortunately, many wells do not penetrate the entirety of the Norphlet so only ten wells were able to be used for the isopach. In

GeoGraphix, the isopach was created using minimum curvature and a geologic bias of $55^{\circ}$ at a magnitude of four to account for the trend of the paleo-highs and lows. The isopach shows that the thickest deposits of the Norhplet occur in Mobile Bay and western Pensacola and Destin Dome.

Analysis of the v-shale was done using the following equation; shale volume: VshI[] = $\min (1, \max (0,(G R[]-G R c l n) /(G R s h l-G R c l n)))$. Similar to the isopach map, v-shale contours were created using minimum curvature and a geologic bias of $55^{\circ}$ at a magnitude of four as well as hand edited where needed. The distribution of v-shale showed that a lower $(>0.6) v$-shale 
correlates to areas of predominantly eolian facies (Fig. 47). Regions with high v-shale correlate to either wadi or proximal alluvial facies. Unfortunatly, these two facies can not be distinguished by log data in the study area as there is only one well that intersects the alluvial fan facies and the log data is not well defined (Scott, 1991). The region of wadi facies within the Apalachicola Embayment is in agreement with Hunt (2012) who identified several wadi and shale facies from 61 wells throughout this area.

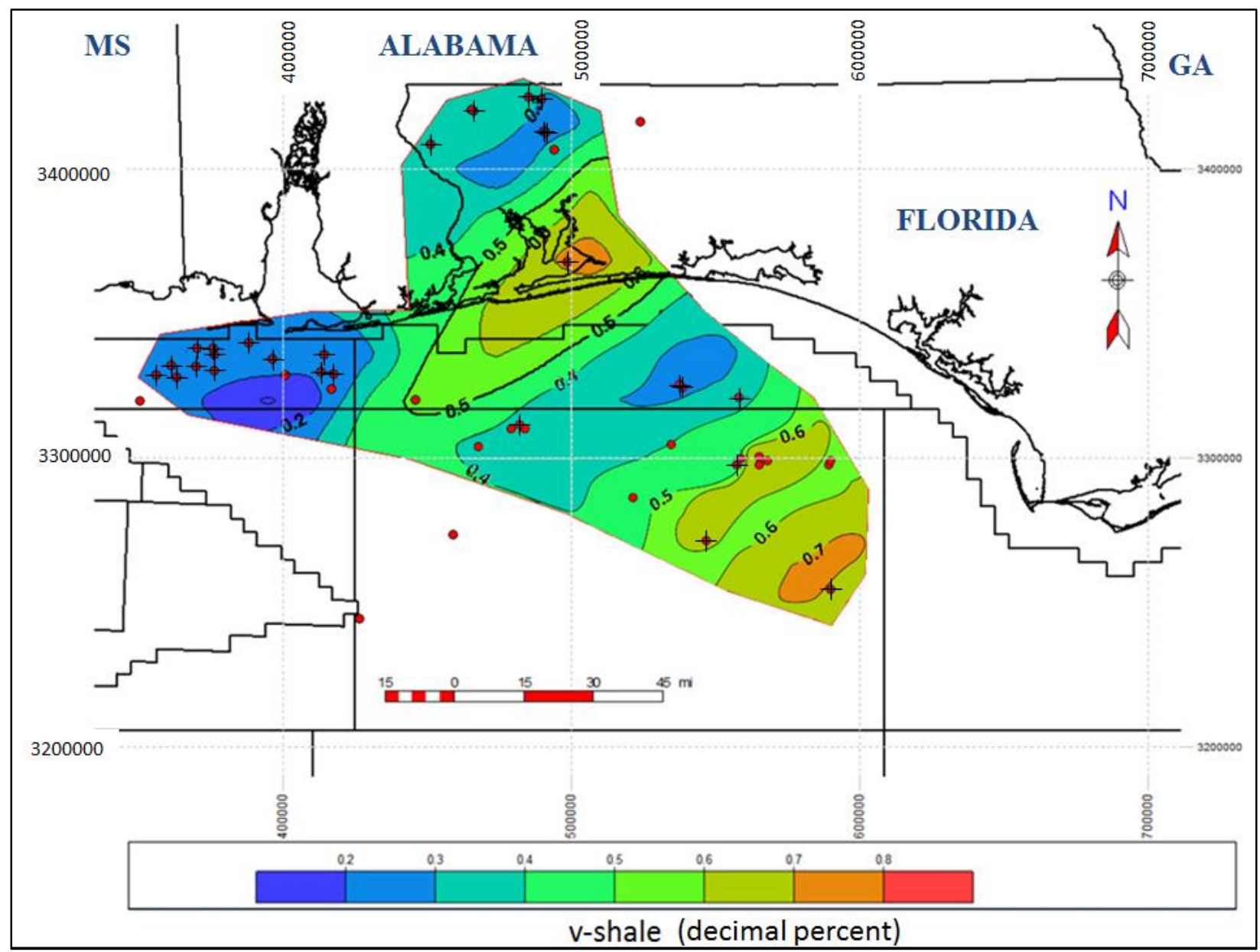

Figure 47. Average shale volume distribution (28 wells used, marked with cross symbol). 


\section{Discussion}

\subsection{Possible Source Areas}

The rifting of Pangea is thought to have left a remnant of Gondwana, the Suwannee Terrane, attached to the Laurentian Craton (Chowns and Williams, 1983; Dallmeyer, 1987). Deposition of the Norphlet and surrounding formations during the rifting of Pangea could have resulted from sediment input from either or both of these two land masses. To distinguish between Gondwanan- or Laurentian-derived zircon, various source terranes and tectonic events within them are defined. Gondwanan sources include zircon within age ranges that correlate to the Pan-African event (500-680 Ma) and Trans-Amazonian/Eburnean event (1900$2250 \mathrm{Ma}$ ) (Mueller et al., 1994; ). Laurentian sources include zircon derived from the Laurentian craton (Granite-Rhyolite, Yavapai-Mazatzal, Mid-continent, and Wyoming/Superior provinces), Grenville basement, the Appalachian mountain building events (Taconic, Acadian, and Alleghanian orogenies), and rifting events including Pangea, Rodinia, and Mt. Rogers (Becker et al., 2005; Park et al., 2010).

Figure 48 shows the relative probability plot of all ten samples, 867 zircon dates, and the possible source terranes and tectonic events from which zircon could be derived. Due to the potential for a recycled origin of many of the zircon grains in the Norphlet, it is difficult to interpret provenance. In order to evaluate sediment source within the study area, geochronologic source terranes are identified based on the suites of $\mathrm{U}-\mathrm{Pb}$ age distributions. This study identified the same four source areas as Lovell (2013) based on the U-Pb detrital 


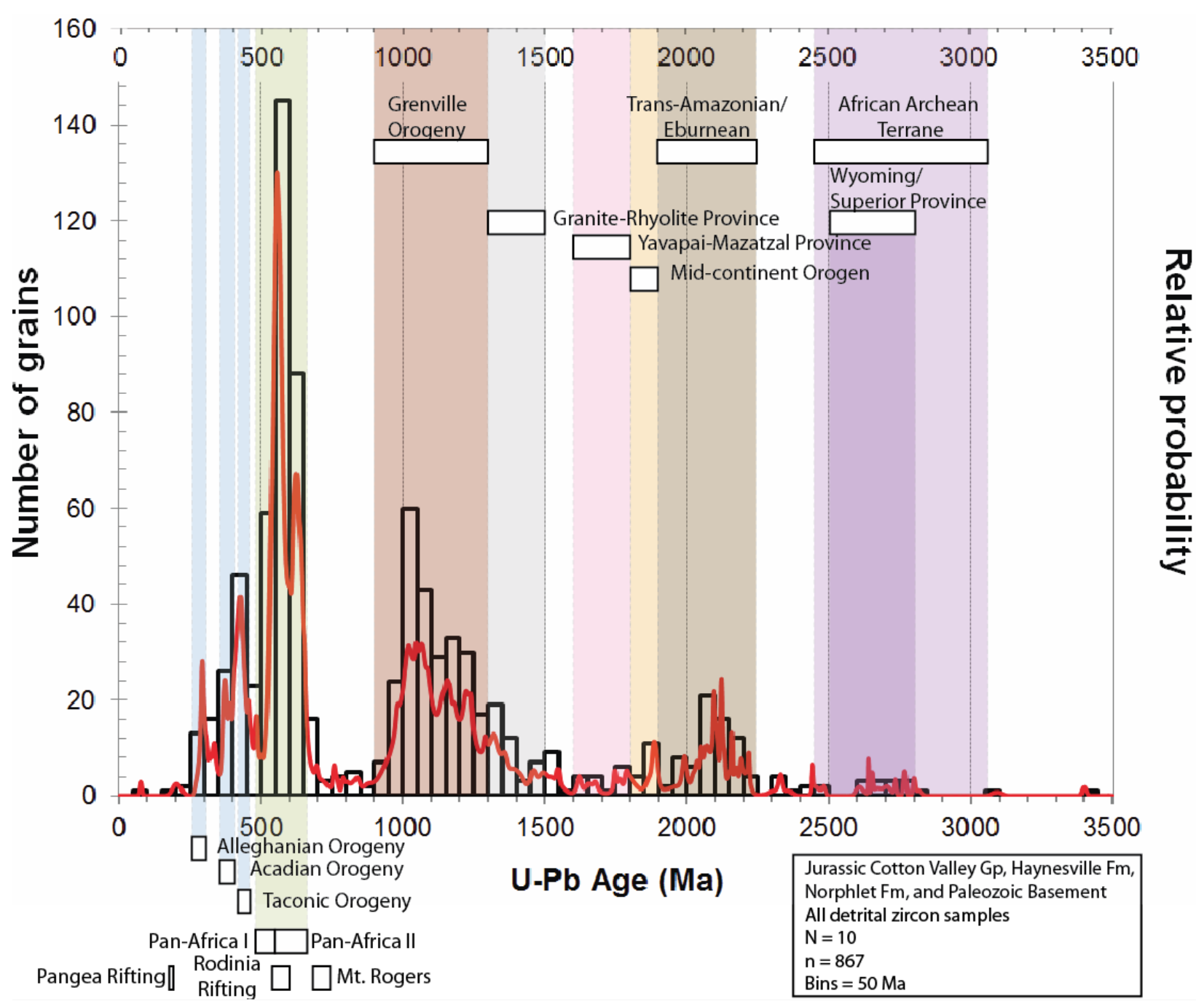

Figure 48. Relative probability plot of all ten samples, 867 zircon. Appalachian mountain building events include Alleghanian, Acadian, Taconic, and Grenville. Laurentian Craton includes Granite-Rhyolite, Yavapai-Mazatzal, Mid-continent, and Wyoming-Superior Provinces. Gondwanan events include Pan-African, Trans-Amazonian /Eburnean, and Archean African Terrane. Rifting events include Pangea, Rodinia, and Mt. Rogers. Red line is the relative probability of all 867 detrital zircons. Black boxes are number of grains with bins set at $50 \mathrm{Ma}$.

zircon age distributions; the Suwannee Terrane, the Mesozoic rift basin, the Appalachian

hinterland and related Wiggins Arch, and Appalachian foreland basin (Fig. 49). Each

geochronologic source terrane and their various provenance components are discussed below. 


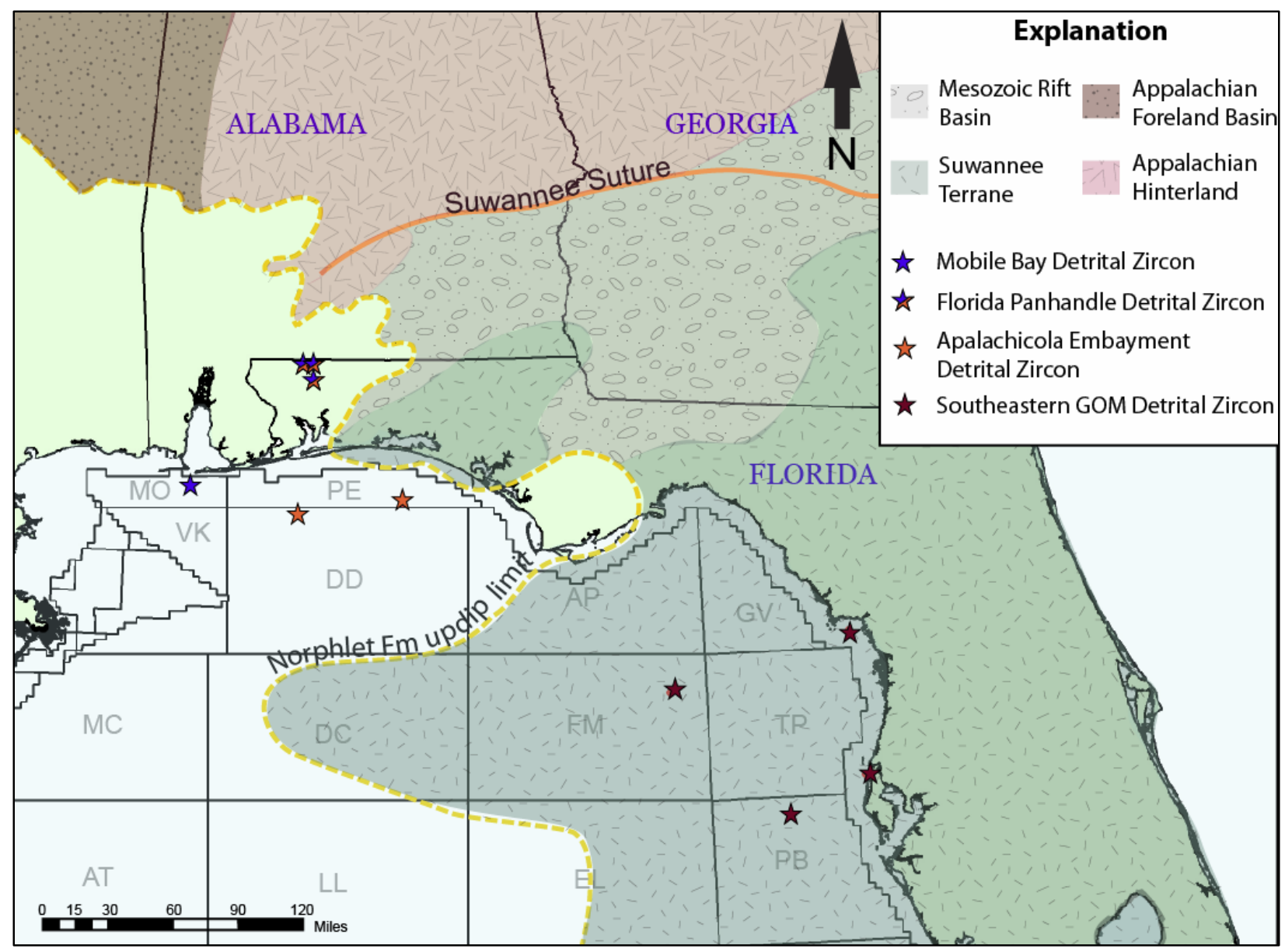

Figure 49. Four geochronologic source terranes identified include Appalachian hinterland, Appalachian foreland basin, Mesozoic rift basin, and the Suwannee Terrane. Stars represent samples with similar U-Pb age distributions.

\subsubsection{Suwannee Terrane}

The Suwannee Terrane is exotic with respect to Laurentia and is thought to be Gondwanan (Chowns and Williams, 1983; Dallmeyer, 1987; Arthur, 1988). The terrane was sutured to the southeastern margin of Laurentia during the Alleghanian orogeny (315-285 Ma; Dallmeyer, 1989; Hibbard et al., 2002) and consists of six pre-Middle Jurassic (basement) provinces: Late Precambrian to Early Cambrian felsic intrusive and extrusive rocks, Osceola Granite, St. Lucie metamorphic complex, Ordovician to Devonian sedimentary rocks, and early to middle Mesozoic hypabyssal and extrusive mafic rocks (Fig. 50; Arthur, 1988; Dallmeyer, 
1989). It has been proposed that underlying these provinces is granitic and metamorphic basement from the African Craton (Chowns and Williams, 1983; Dallmeyer, 1989).

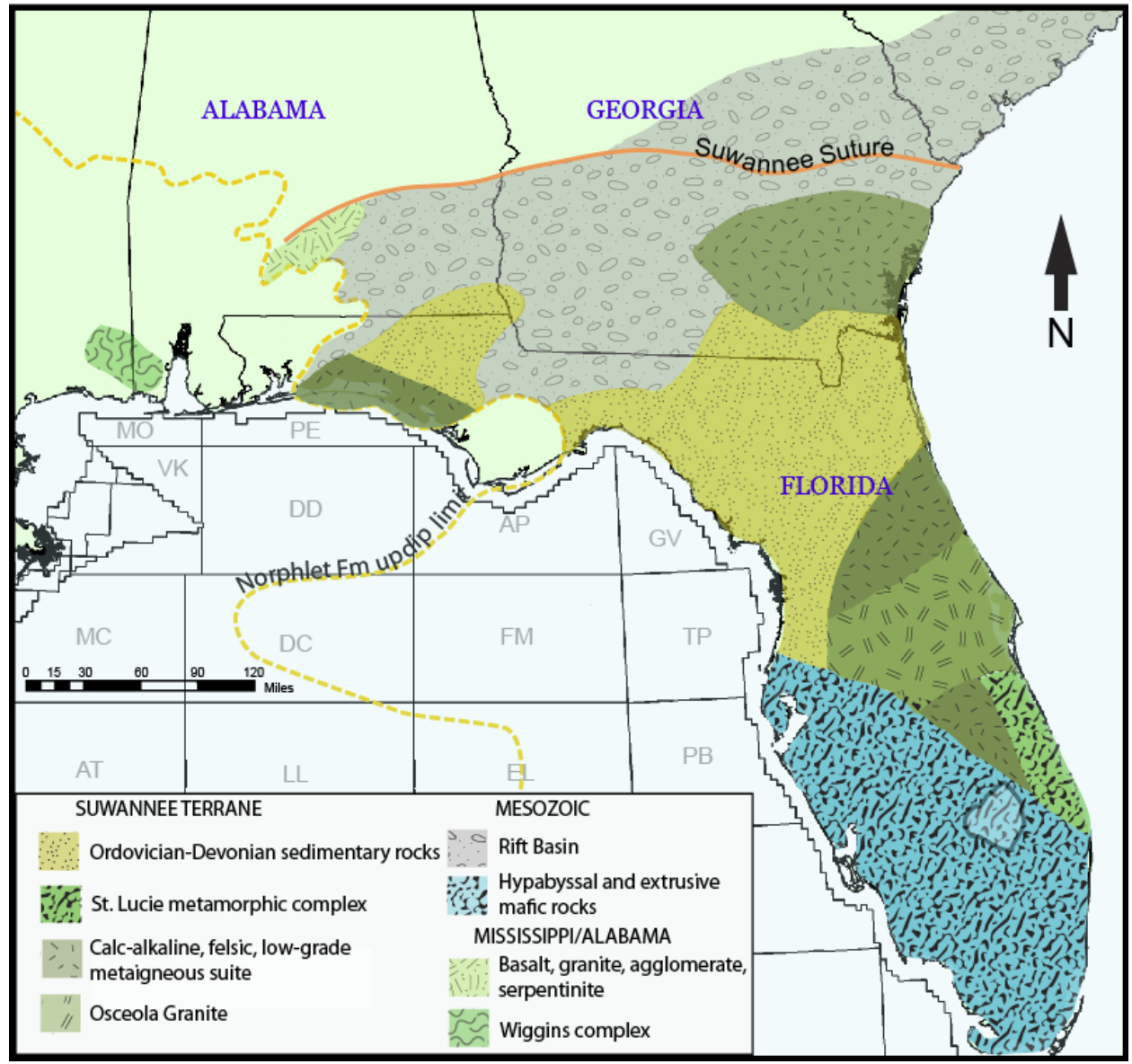

Figure 50. Lithology of the Florida basement (after Dallmeyer, 1989; Chowns and Williams, 1983; Arthur, 1988).

The Late Precambrian to Early Cambrian felsic intrusive and extrusive rocks in the Florida Panhandle are separated by a nonconformity from the overlying Ordovician to Devonian sedimentary strata in the Florida peninsula. The igneous rocks are all considered to be from the same province due to the similarity in lithology (Chowns and Williams, 1983). Radiometric ages have varied significantly for this province with an unpublished age of $709+/-25 \mathrm{Ma}$ from K-Ar (feldspar) obtained from a granodiorite from the coastal, central Florida Panhandle (Arthur, 1988) to a plateau age of $\sim 375 \mathrm{Ma}$ (Dallmeyer, 1989). It has been proposed that 
Devonian ages likely represent a low-grade metamorphic overprinting as opposed to cooling during the initial magmatism (Chowns and Williams, 1983; Dallmeyer, 1989).

The Osceola Granite is an undeformed granite composed primarily of oligoclase, quartz, perthitic feldspar, and biotite. ${ }^{40} \mathrm{Ar} /{ }^{39} \mathrm{Ar}$ isotopes from biotite have produced an age plateau ranging from 535 to 527 Ma (Chowns and Williams, 1983; Dallmeyer, 1989). Cooling of the pluton is thought to have occurred relatively quickly and at shallow crustal depths due to the lack of exsolution and/or recrystallization of feldspar grains (Dallmeyer, 1989).

The St. Lucie metamorphic complex consists of high grade metamorphic rocks including dioritic gneiss, amphibolite, and biotite-muscovite schist (Arthur, 1988; Dallmeyer, 1989). Isotopic ages range from $530 \mathrm{Ma}$ (Rb-Sr, biotite) to $503 \mathrm{Ma}\left(\mathrm{K}-\mathrm{Ar}\right.$, hornblende). ${ }^{40} \mathrm{Ar} /{ }^{39} \mathrm{Ar}$ isotopes identified plateau ages of 513 and 511 Ma which has been interpreted to represent post-metamorphic cooling (Dallmeyer, 1989).

Overlying the Late Precambrian to Early Cambrian felsic intrusive and extrusive rocks are sedimentary rocks from the Ordovician to Devonian. These consist of Lower Ordovician quartz arenites and Ordovician to Middle Devonian shales and siltstones (Chowns and Williams, 1983; Arthur, 1988; Dallmeyer, 1989). Detrital zircon age populations previously found in these sediments include a dominance of 515-635 Ma and 1967-2250 Ma (Mueller, 1994; Heatherington and Mueller, 1999). This correlates with the Trans-Amazoninan/Eburnean Orogens dated from 1900-2250 Ma (Hartmann, 2002; Schofield and Gillespie, 2007; Park et al., 2010) and the Pan-African/Brasiliano Orogens dated from 530-680 Ma (Hoffman, 1999; Park et al., 2010). Other less abundant age populations identified include $2433 \mathrm{Ma}$ and $2700 \mathrm{Ma}$ (Heatherington and Mueller, 1999). These ages are coeval with ages 2450-3040 Ma for 
metamorphic and igneous rocks of the Archean Terrane (U-Pb; Schofield and Gillespie, 2007). Ages obtained from this study also include a "Grenville" age population for these sediments (samples P383 and P382). Likely sources for these zircon include the South American Sunsas belt dated from 1000-1560 Ma (U-Pb zircon; Bettencourt et al., 2010) and various central and southern African orogenic belts (e.g. Namaqua and Mozambique) that range from 900-1300 Ma with U-Pb detrital zircon age peaks at 1,000 and $1170 \mathrm{Ma}$ (Condie et al., 2009).

\subsection{1.a. Rokelide Fold Belt}

It has been proposed that the Suwannee Terrane is part of the Rokelide Fold Belt from the western side of the West African Craton (Fig. 51; Chowns and Williams, 1983; Arthur, 1988; Dallmeyer, 1989). The Rokelide orogeny along with the Bassaride-Mauritanide orogenic events are part of the Pan-African tectonothermal event. Evidence for this is supported by geochronology, paleontology, petrography, and stratigraphy. Similar petrography and crystallization ages ( $530 \mathrm{Ma}$ ) exist for both the Osceola Granite in Florida and the Coya Granite in the Northern Rokelide Orogeny (Dallmeyer, 1989). Similarities have also been found between the Ordovician-Devonian stratigraphy and paleonology of the Suwannee Terrane and the Bove Basin of West Africa. Lastly, the St. Lucie metamorphic complex has yielded similar ages as those from post metamorphic cooling in the Rokelide belt (Chowns and Williams, 1983; Dallmeyer, 1989). 


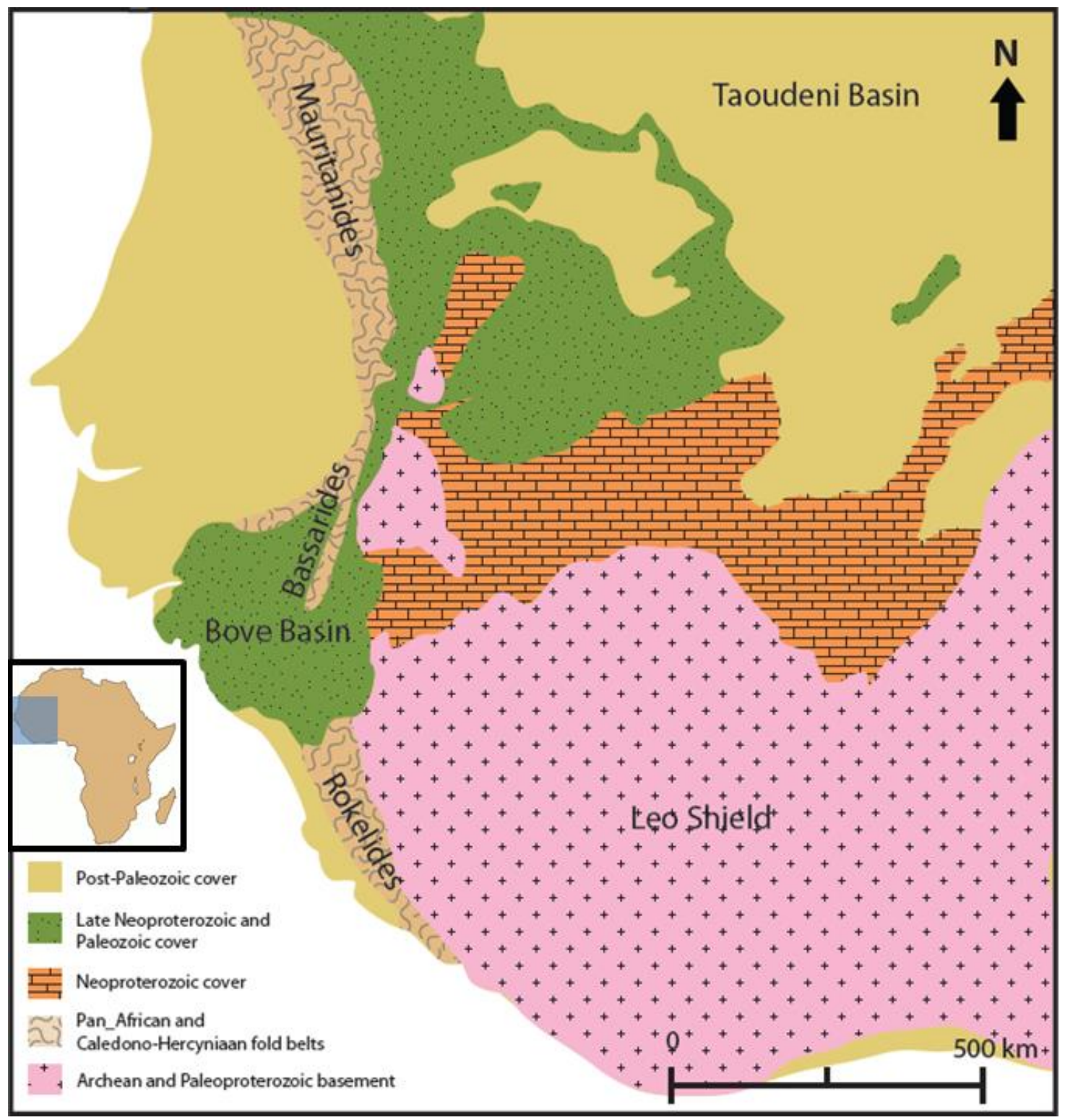

Figure 51. West African Mauritanides, Bassarides, and Rokelides orogenies (modified from Deynoux et al., 2006).

The Pan-African event is separated into two phases, Pan-Africa I that includes the Bassaride-Mauritanide orogenies, which have developed from $650-680 \mathrm{Ma}\left({ }^{40} \mathrm{Ar} /{ }^{39} \mathrm{Ar}\right.$ micaschist; Dallmeyer and Villeneuve, 1987; U-Pb zircon; Dallmeyer, 1989), and Pan-Africa II that includes the Rokelide orogeny (Culver et al., 1991; Veevers, 2007; Villeneuve, 2008), which formed at $550 \mathrm{Ma}$ (U-Pb zircon; Delor et al., 2002 and K/Ar schists and granitoids; Hurley et al., 1971). These two Pan-African events were followed by post-collisional intrusions from 550-660 
Ma (Pan Africa I) and 533-500 Ma (Pan Africa II; Culver et al., 1991; Veevers, 2007; Villeneuve, 2008).

The basement rock beneath the West African orogenies is another component of the Suwannee Terrane which includes a Liberian province ( 2700 Ma; Culver et al., 1991;

Dallmeyer, 1989), Eburnean province (2050-2150; Park et al., 2009; Schofield and Gillespie, 2007; Culver et al., 1991;), granitic plutonism (1800 Ma; Dallmeyer, 1989), and Pan-African (550 Ma; Villeneuve, 2008; Veevers, 2007; and Culver et al., 1991). The Liberian Province consists of metamorphic rock of high-grade amphibolite gneisses (Dallmeyer, 1989 and Culver et al., 1991). The Eburnean rocks also consist of amphibolite-grade migmatic gneiss as well as metamorphosed shelf sediments to form quartzite and marble (Schofield and Gillepie, 2007; Culver et al., 1991; and Dallmeyer, 1989). At around $1800 \mathrm{Ma}$, widespread intrusions of granitic plutons occurred (Dallmeyer, 1989). The Pan-African basement rocks, which consist of reworked Archean rocks, are separated into the Kasila Group and the Kenema Assemblage. The Kasila Group consists of high-grade metamorphic rock of granulite facies. The Kenema Assemblage consists of lower-grade greenstone and migmatic granites and gneisses (Culver et al., 1991).

\subsubsection{Mesozoic Rift Basin}

The Mesozoic Rift Basin of the southeast U.S. subsurface has been interpreted to be a Triassic graben filled with redbeds and associated basalts, diabases, and dacitic ash fall tuffs (Heatherington and Mueller, 1999; Arthur, 1988; and Chowns and Williams, 1983). These rift related rocks are dated from Late Triassic, 203 +/- 12 Ma to Early Jurassic, 182 +/- 11 Ma (K-Ar whole rock; Heatherington and Mueller, 1999). Ages of volcanic rocks in the Mesozoic Rift 
Basin are similar to the hypabyssal and extrusive mafic rocks in the South Florida Basin which have a 189 +/- $5 \mathrm{Ma} \mathrm{Rb-Sr}$ whole rock age (Arthur, 1988). However, the two regions of extrusive rocks are not thought to be genetically related. The basalts of the South Florida Basin range from tholeiitic to alkaline with associated alkaline rhyolites whereas the Mesozoic Rift Basin basalts are solely tholeiitic in composition. Heatherington and Mueller (1999) preformed trace element and isotopic analysis on the two mafic volcanic suites. They found that the northern Florida basalts were derived from continental lithosphere and that the basalts from the South Florida Basin show evidence for the presence of a mantle plume below.

During Triassic rifting, this basin likely acted as a depocenter for both Laurentian and Gondwanan sediment. The rift basin trends east-northeast and west-southwest from the Florida Panhandle to southern Georgia and cuts across both the Appalachain Mountains and the Suwanne Terrane. Thus rifting could have exposed both Grenville and African Suwannee basement from which zircon could be derived and deposited in the Norphlet Formation.

\subsubsection{Appalachian Mountains}

The Appalachian orogen contain both Laurentian- and Gondwanan-affinity rocks.

Previous studies by Park et al. (2010) and Becker et al. (2005) have identified several Laurentian sediment sources based on U-Pb detrital zircon geochronology. These include sediments shed from the Grenville basement rocks, Rodina rift rocks, Taconic orogen, Acadian orogen, and the Alleghanian orogen. The Grenville basement rocks are predominantly gneiss and provides the most abundant detrital zircon age group in Appalachian foreland basin deposits (900-1300 Ma;

Park et al., 2010). Rodinia rifting consists of two age groups, 700-760 Ma from the Mt. Rogers volcanics which represents failed rifting, and 550-620 Ma from the Catoctin Greenstones 
representing the opening of the lapetus Ocean (Park et al., 2010). The Taconic Orogeny, 430$480 \mathrm{Ma}$, is represented by granulite facies and kyanite grade metamorphic rocks that have been dated $465 \mathrm{Ma}$ (Hibbard et al., 2002; Park et al., 2010). The Acadian Orogeny produced rocks of two distinct ages: plutonism and low to high-grade metamorphic rocks from a northern deformational front (384-425 Ma; Park et al., 2010) and southern granitoid plutonism (374-382 Ma). The Alleghanian Orogeny consists of magmatism from subduction and regional metamorphism of the green schist and amphibolite facies dating 300-325 Ma (Park et al., 2010). It also consists of a foreland fold and thrust belt that migrated from north to south during approximately 280-300 Ma in the southern Appalachians (Becker et al., 2005; Park et al., 2010). The Gondwanan component of the Appalachian orogen is the Carolina Terrane which is made up of several exotic Neoproterozoic to early Paleozoic terranes of the southern Appalachians that are thought to be part of Gondwana accreted along the eastern margin of Laurentia. The history of terrane accretion and associated magmatism occurred in three stages, pre $600 \mathrm{Ma}, 590-530 \mathrm{Ma}$, and younger than $530 \mathrm{Ma}$ (Hibbard et al., 2002). Terranes in this zone include the Roanoke Rapids Terrane, Spring Hope Terrane, Uchee Terrane, Pine Mountain Terrane, Savannah River Terrane, and Charlotte Terrane. These terranes consist primarily of metamorphic rocks with very minor undeformed igneous rocks.

The oldest terrane in the Carolina Terrane is the 607-672 Ma (U-Pb zircon) Roanoke Rapids Terrane and consists of low-grade mafic-ultramafic (ophiolitic) rocks, tonalite to quartzdiorite and metavolcanics, felsic volcanic and phyllitic volcaniclastics (Hibbard et al., 2002). The 620-640 Ma (U-Pb zircon) Uchee Terrane is made up of gneiss, schist, and amphibolite (Steltenpohl et al., 2008). The Savannah River Terrane consists of $620 \mathrm{Ma}$ (U-Pb zircon) 
migmatitic gneiss and schist as well as Carboniferous $\left({ }^{40} \mathrm{Ar} /{ }^{39} \mathrm{Ar}\right)$ underformed granite plutons (Hibbard et al., 2002).

The 544-590 Ma (U-Pb zircon) Spring Hope Terrane consists of greenschist facies, including metavolcanics with metaplutonic and metasedimentary rocks (Hibbard et al., 2002). The Charlotte Terrane is predominantly 538-579 Ma (U-Pb zircon) metaigneous rocks that date with intruded plutonic rocks that formed from 570-580 Ma and 530-540 Ma (U-Pb; Hibbard et al., 2002).

The Pine Mountain Terrane consists of quartzite, marble, and schist. This terrane has been interpreted to be metamorphosed Grenville basement and bears 270-295 Ma U-Pb ages from Rutile (Steltenpohl et al., 2008). Also called the Pine Mountain Window, this region is an exposure of the North American Grenvillian crust (Steltenpohl et al., 2008).

\subsubsection{Appalachian Foreland Basin}

Sediments shed into the Appalachian foreland basin could have originated from several Laurentian Provinces as well as from the Appalachian hinterland. Park et al. (2010) summarized ages of sediment derived from the various Laurentian provinces, including detritus from the Superior Province (2700-2800 Ma), Wyoming Province (2500-2700 and 1600-1800 Ma), TransHudson Province (1800-1900 Ma), Yavapai Province (1700-1760 Ma), Mazatzal (1700-1800 and 1600-1660 Ma), and the Granite and Rhyolite Province (1300-1500 Ma; Fig. 52). 


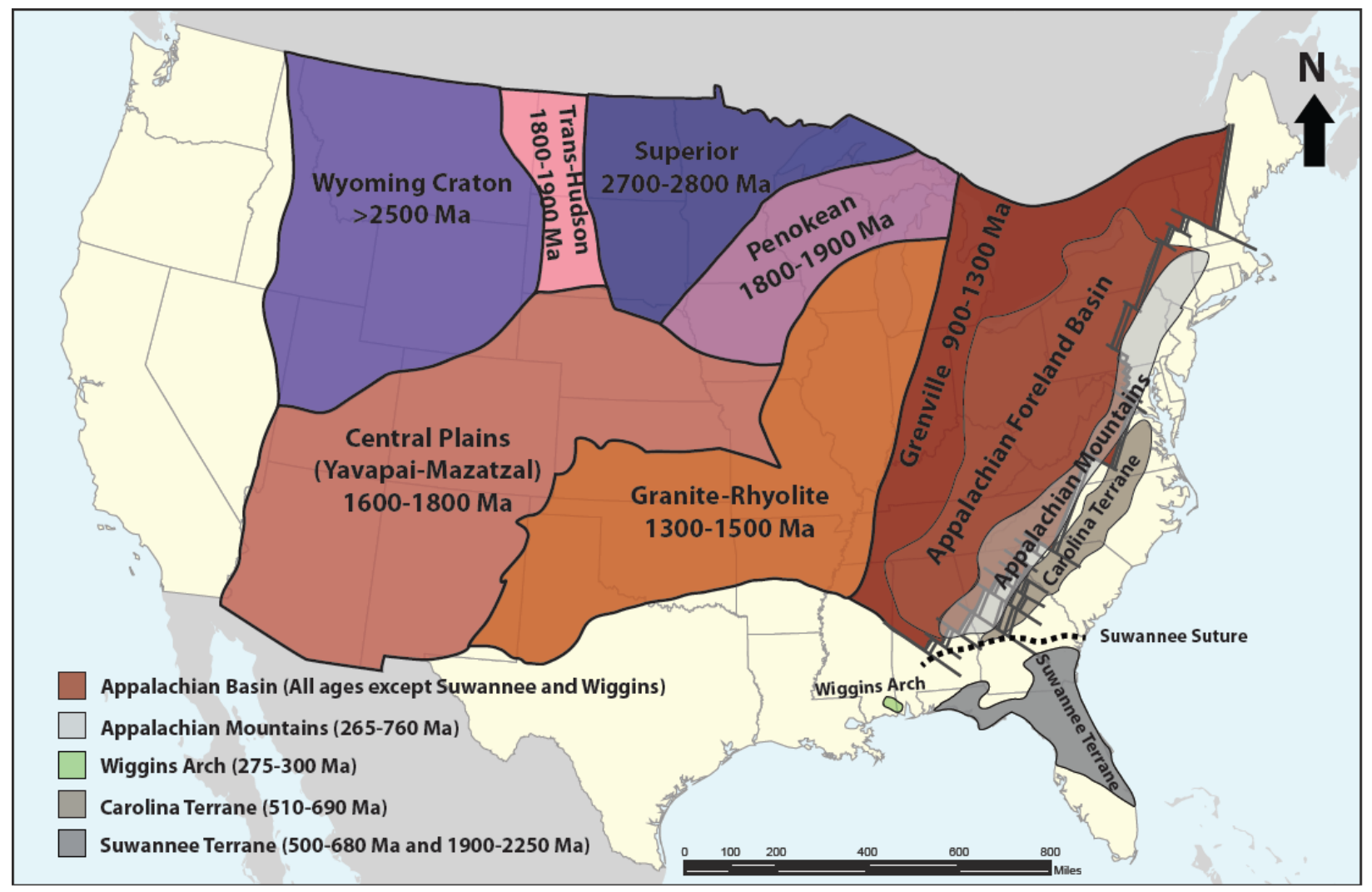

Figure 52. Laurentian basement provinces (modified from Park et al., 2010), Appalachian Mountains and associated foreland basin (Lovell, 2013), Wiggins Arch (Dallmeyer, 1989; Arthur, 1988), and accreted terranes including the Carolina (Hibbard et al., 2002) and Suwannee terrane (Dallmeyer, 1989). Suwanne suture from Steltenpohl et al. (2008).

\subsection{4.a Wiggins Arch}

The Wiggins Arch is an uplifted block of metamorphic rocks in southwestern Alabama and southeastern Mississippi. It consists predominantly of phyllite, schist, quartzite, qneiss, amphibolite, and deformed granite that formed between 275 and 300 Ma (K-Ar whole Rock; Dallmeyer, 1989; Tew et al., 1991). The Wiggins Arch sits between two Mesozoic faults and lies next to the southwestern extension of the Appalachian piedmont (Tew et al., 1991). The geologic evolution of the Wiggins Arch is still poorly known but is not considered part of the Suwannee Terrane as it records Paleozoic metamorphism whereas the Suwannee Terrane doesn not (Dallmeyer, 1989). 


\subsection{U-Pb Ages within known Provenance Range}

The degree to which these previously discussed sources contributed sediment to the Norphlet and surrounding formations varies across the study area. Of the 867 zircons with useable dates, 777 fit into known source regions discussed above (Fig. 53; See Appendix 3). The following discussion will assess the various provenance contributions to the ten detrital samples as well as the decision process for assigning U-Pb ages to a particular provenance, especially for source areas that overlap in age.

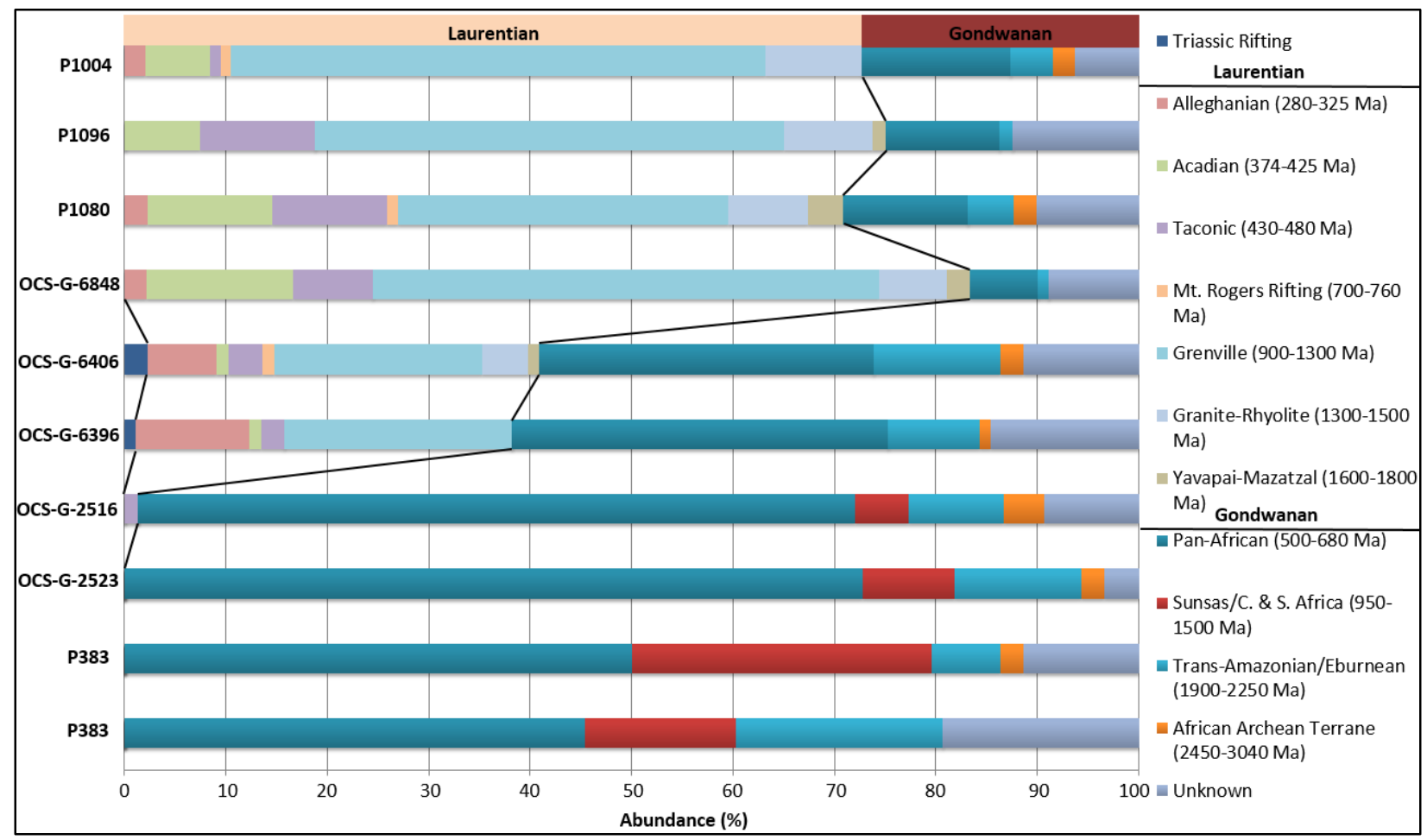

Figure 53. Normalized abundance of detrital zircon $\mathrm{U}-\mathrm{Pb}$ grouped according to potential source terranes.

\subsubsection{Triassic Rifting}

The Destin Dome and Pensacola offshore lease block samples contain zircons produced from Triassic rift volcanism. Both of these samples are located within the Apalachicola Embayment and are proximal to known volcanism during this time. Figure 6 shows the location 
of volcanism during the Triassic in and around the study area (Chowns and Williams, 1983;

Arthur, 1988; Heatherington and Mueller, 2003).

\subsubsection{Appalachian Orogen Source}

Samples P1004, P1080, OCS-G-6848 (MO), OCS-G-6406 (DD), and OCS-G-6396 (PE) have Alleghanian-aged zircons (Fig. 53). However, in samples P1004, P1080, and OCS-G-6848, this population only makes up $2 \%$. For the Destin Dome and Pensacola samples, this population is a lot larger from $7 \%$ to $11 \%$, respectively. The samples that contain Acadian-aged zircons include the Florida Panhandle samples (P1004, P1096, and P1080), Apalachicola Embayment samples (OCS-G-6406 and OCS-G-6396), and Mobile Bay sample (OCS-G-6848). This population ranges from 1\% (OCS-G-6406 and OCS-G-6396) to 14\% (OCS-G-6848). Taconic-aged zircons are found in the Florida Panhandle wells (1-11\%) as well as Mobile Bay (8\%), Destin Dome (3\%), Pensacola (2\%), and Florida Middle Ground (1\%). Overall, there is a southwestward increase in Appalachian orogen-aged zircon abundance from the Florida Panhandle samples to the Mobile Bay sample. There is also a southward decrease in Appalachian orogen-aged zircon from the Florida Panhandle samples to the Apalachicola Embayment samples which are separated by the Pensacola Arch.

\subsubsection{Pan-African Source}

Pan-African-aged zircons exist in all samples (Fig. 53). The population is the smallest in the Mobile Bay sample at 7\%. The proportion of these Pan-African-sourced zircon in the Florida Panhandle samples are similar ranging from 11-15\%. The Destin Dome and Pensacola samples have a higher proportion at $33 \%$ to $37 \%$, respectively. For the southeastern samples (OCS-G2516, OCS-G-2523, P383, and P382), this population makes up the largest portion of zircon 
ages. For samples OCS-G-2523 and OCS-G-2516, it makes up 71\% to 73\%, respectively. For samples P383 and P382 this population makes up 50\%. Geographically, the abundance of PanAfrican-aged zircon increases to the southeast and is the smallest in the Mobile Bay sample and largest in the Florida Middle Ground and St. Petersburg samples (OCS-G-2516 and OCS-G-2523).

\subsubsection{Grenville and the Gondwanan Sunsas and South and Central African Orogenies}

Previous studies have shown that within the Appalachian foreland basin, Grenville-aged zircons are the most pervasive, found throughout the Paleozoic basin fill (Park et al., 2010; Becker at al., 2005). Park et al. (2010) performed U-Pb detrital zircon geochronology on Appalachian basin sediments from the Taconic, Acadian, and Alleghanian clastic wedges, all of which showed a Grenville-aged population that composed from $40-80 \%$ of the total sample, averaging about $61 \%$. The Grenville population for this study ranges from $20-53 \%$ of those samples that contain it (Table 3). The largest portion of Grenville-aged zircon occur in samples P1004 (53\%), Mobile Bay (50\%), and P1096 (46\%). P1080 has a smaller portion at 33\% while Pensacola and Destin Dome are even smaller at 20 and 22\%, respectively. Figure 54 shows a comparison between the normalized relative probability plot of Park's cumulative data set which illustrates the large Grenville influence on the Appalachian foreland basin sediments. In comparison, the Grenville influence on the Norphlet Formation appears to be smaller, especially in the Apalachicola Embayment samples (OCS-G-6406 and OCS-G-6396). 
Table 3. Comparison of Grenville-aged zircon between Park et al. (2010) and this study.

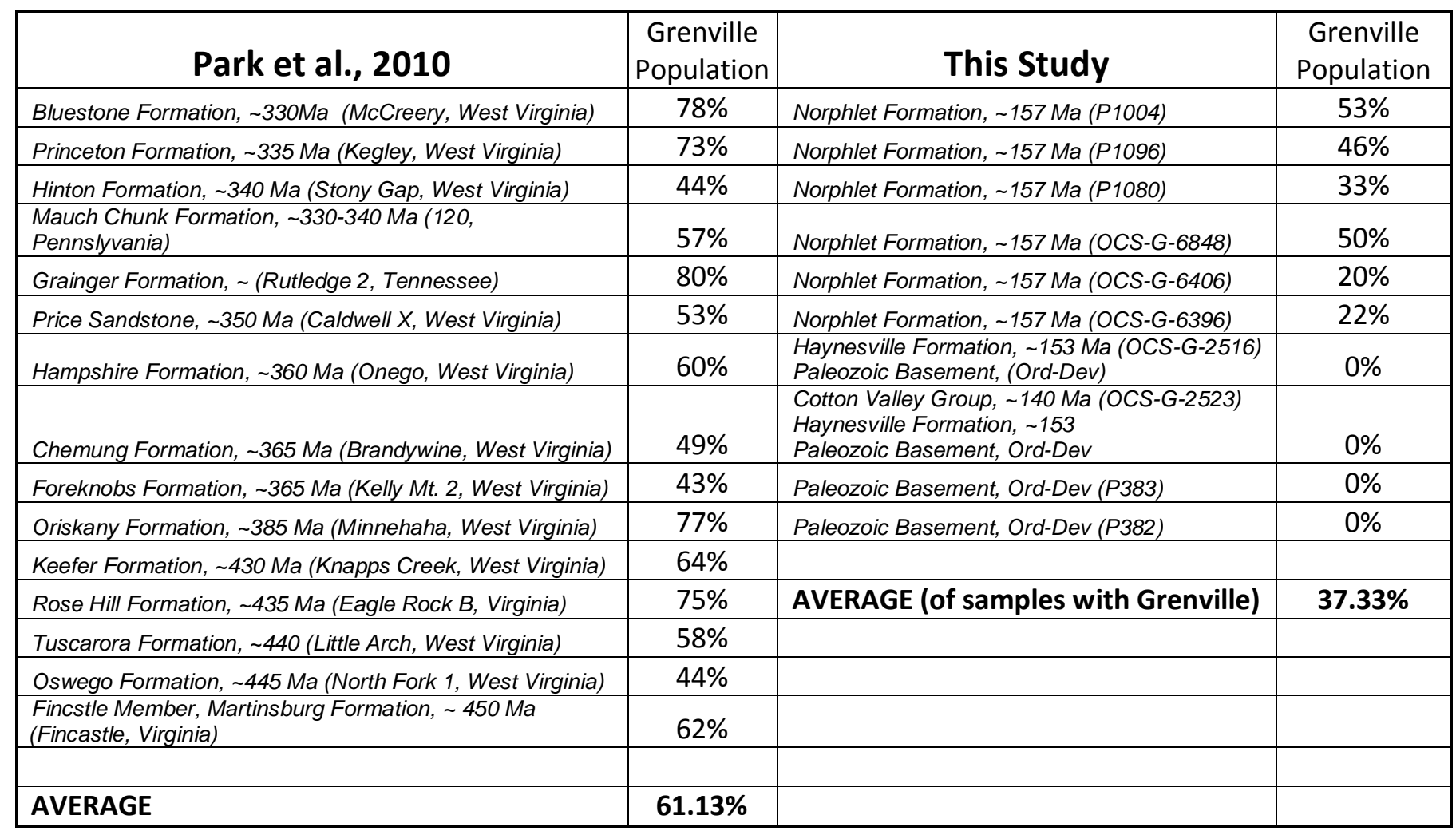

The four southeastern samples of this study (OCS-G-2516, OCS-G-2523, P383, and P382) also contain zircon populations of Grenville age ranging in abundance from 5-25\% but were not classified as such. This is because the Grenville population of these four samples is largest in the Gondwanan, Paleozoic basement samples (P383-P382) which consist of sediments deposited during the Ordovician-Devonian when Gondwana was not attached to the Laurentian craton and there could be no Laurentian influence (e.g., Grenville). Other potential sources for these Grenville-aged zircon can be inferred from Condie et al. (2009) who compared detrital and igneous zircon data across continents. Condie's study shows Grenville-age peaks in both South America and Africa (Fig. 55) that are attributed to the Sunsas belt in South America and various orogenies in South and Central Africa (Condie et al., 2009). Therefore, "Grenville- 


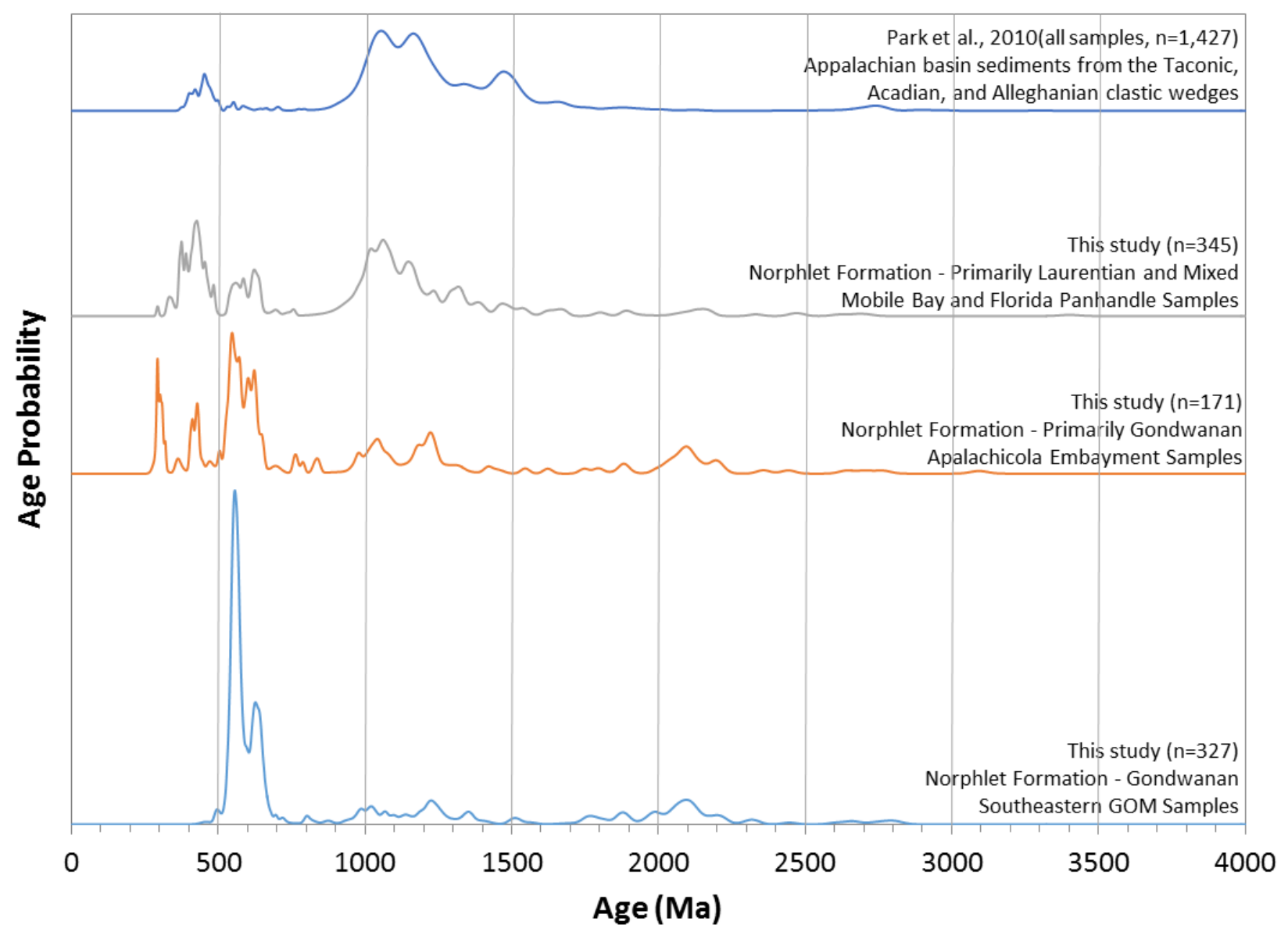

Figure 54. Normalized relative probability curves for cumulative data of the Mobile Bay and Florida Panhandle samples (grey), Apalachicola Embayment samples (orange), and southeastern GOM samples (light blue) of this study and and Park et al. (2010; blue). As opposed to this study which focuses on Jurassic sediment and Paleozoic basement in the eastern Gulf of Mexico, Park et al. (2010) focused on Appalachian foreland basin sediments. 
aged" zircon in the Gondwanan

basement samples P383 and P382

and proximal OCS-G-2516 and OCS-

G-2523 samples, are classified as

South America/African and not as

Grenville. The portion of South

American/African zircon in the

Jurassic and basement samples

OCS-G-2523 and OCS-G-2516 is

much lower (5-9\%, respectively)
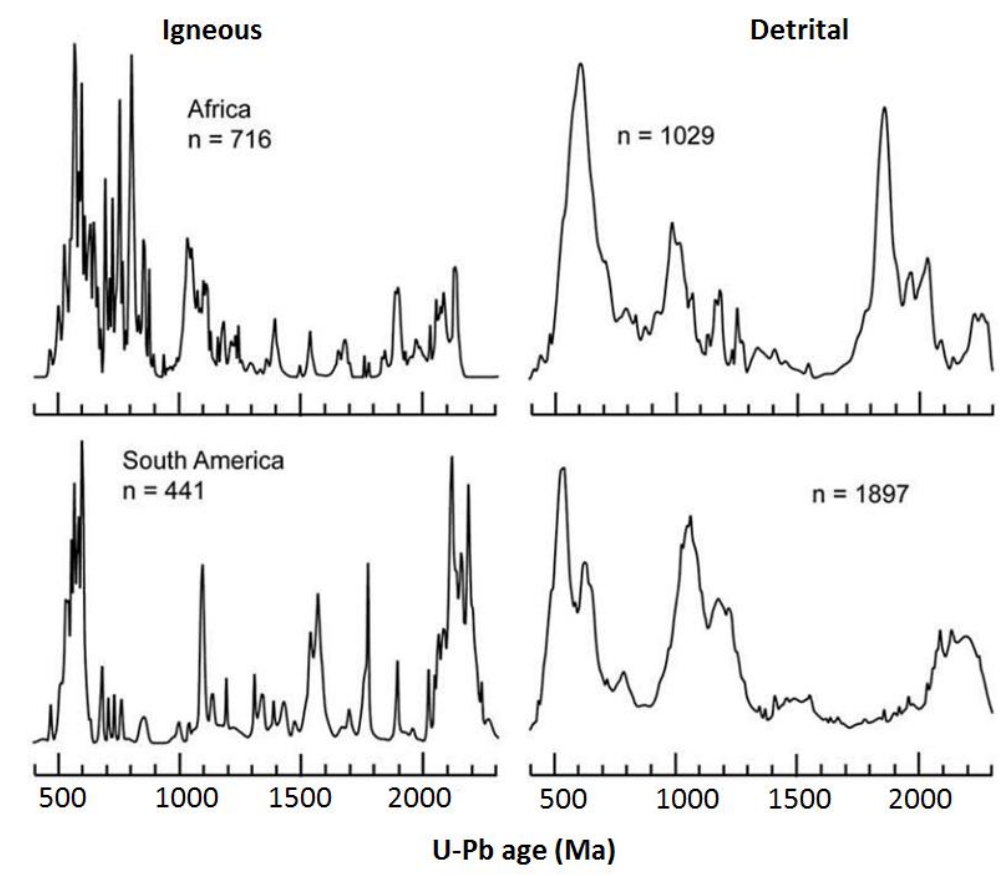

Figure 55. Probability density plots of igneous and detrital U-Pb age distributions between 400-2300 Ma from Africa and South America (Condie et al., 2009)

than they are for the basement

samples P382 and P383 (15-30\%, respectively).

\subsubsection{Laurentian Craton Source}

Zircon sourced from the Granite-Rhyolite Province are present in the Florida Panhandle and Mobile Bay samples (7-9\%) and less abundant in the Destin Dome sample (5\%). YavapaiMazatzal-aged zircon are present in the P1096, P1080, Mobile Bay, and Destin Dome samples ranging from 1-3\%. While the Pensacola sample has 2 ages (1747 and $1749 \mathrm{Ma}$ ) that coincide with the Yavapai-Mazatzal time range, they were not considered so. The Pensacola sample shows a much smaller influence from Laurentia and the Appalachian orogen in other age populations. These two ages more likely correlate to the suturing of the Birimian Basement of West Africa that occurred during the Eburnean Orogen with ages that range from 1700-2000 
Ma (Villeneuve, 2008). This event was also likely the source for the small group of $1700-1800$ Ma zircon ages in the Paleozoic basement.

\subsubsection{Trans-Amazonian/Eburnean Orogenies}

Trans-Amazonian/Eburnean-aged zircon are present in all samples in varying abundances. This age population is the smallest in the P1080 and Mobile Bay samples at 1\%. The other Florida Panhandle samples (P1004 and P1096) have only 4\% of this age population. The Destin Dome, Pensacola, Florida Middle Ground, St. Petersburg, and P383 samples have larger abundances ranging from 7-13\%. Florida basement samples P382 has the largest abundance of this population at $20 \%$.

\subsubsection{African Archean Terrane}

The P1004, P1080, Destin Dome, Pensacola, Florida Middle Ground, St. Petersburg, and P383 samples all have a small portion of this age population (1-4\%). These portions were classified as African Archean Terrain (2450-3040 Ma) even though there is some overlap with the Wyoming (>2500 Ma) and Superior (2700-2800 Ma) Provinces. The four southeastern samples (OCS-G-2516, OCS-G-2523, P383, and P382) had zircon ages between 2600-2700 Ma that occur with predominantly other Gondwanan derived grains. The Pensacola sample had one age at 2766 Ma that was classified as African in origin rather than Superior Province due to the smaller influence from Laurentia in the other age populations.

\subsubsection{Ambiguous U-Pb Ages}

Table 4 summarizes the ambiguous ages and potential origins for this study. Only one $\mathrm{U}-\mathrm{Pb}$ age date was found that was younger than the Triassic rifting event and the depositional age of the Norphlet in the Florida Middle Ground sample at 77 (+/- 4.2) Ma. Part of the sample 
was obtained from cuttings, which suggests that the $77 \mathrm{Ma}$ date is due to mixing that occurred during the drilling process and does not belong to the actual formations targeted. Lovell (2013) summarized the potential origins of ambiguous $\mathrm{U}-\mathrm{Pb}$ ages he observed in the Norphlet Formation from the Mobile Bay and Destin Dome offshore lease blocks (Table 4). However, because the southeastern Gulf of Mexico samples of this study are composed almost entirely Gondwanan-derived zircon, Lovell's possible Laurentian sources for 680-700 Ma, 760-900 Ma, and 1500-1900 Ma do not apply. Instead, U-Pb ages for 680-700 and 760-900 Ma likely belong to early and late phases of the Pan-African Orogeny (Condi et al., 2009; Lovell, 2013).

Gondwanan sources experienced long periods of episodic granitoid plutonism that began with the Tran-Amazonian/Eburnean (2200 Ma) events and continued through $1500 \mathrm{Ma}$ (U-Pb; Condi et al., 2009). Condi et al. (2009) attribute the U-Pb ages found in South America and West Africa between 1500-1900 Ma to the accretion of land masses on the western margin of Amazonia. Also, the Birimian Basement of West Africa was sutured together during the Eburnean Orogen with dates that range from 1700-2000 Ma (Villeneuve, 2008).

Table 4. Samples with ambiguous $\mathrm{U}-\mathrm{Pb}$ ages and their potential origin

\begin{tabular}{|l|l|l|}
\hline Ambiguous Age Range & Sample (\# of grains) & Potential Origin \\
\hline 325-374 Ma & $\begin{array}{l}\text { P1004 (2), P1096 (3), P1080 (3), } \\
\text { MO (4), DD (2), FMG (1) }\end{array}$ & $\begin{array}{l}\text { Continued plutonism between Alleghanian and } \\
\text { Acadian orogenies (Lovell, 2013) }\end{array}$ \\
\hline 425-430 Ma & P1080 (2) & $\begin{array}{l}\text { Continued plutonism between the Acadian and Taconic } \\
\text { orogenies, likely northern Appalachians (Lovell, 2013). }\end{array}$ \\
\hline 480-500 Ma & P1096 (3), P1080 (1), DD (1), & $\begin{array}{l}\text { Pan-African material including volcanic arcs of the } \\
\text { Carolina Terrane. }\end{array}$ \\
\hline $680-700 \mathrm{Ma}$ & P382 (2) & Pan-African (Lovell, 2013) \\
\hline $760-900 \mathrm{Ma}$ & PE (3), DD (1), STPB (1) & Pan-African (Condi et al., 2009) \\
\hline
\end{tabular}




\begin{tabular}{|l|l|l|}
\hline 1500-1600 Ma & P1004 (4), P1096 (1), PE (1) & $\begin{array}{l}\text { Pennsylvanian Hammond Fm., Marathon-Ouachita } \\
\text { Orogey (Lovell, 2013) }\end{array}$ \\
\hline 1800-1900 Ma & $\begin{array}{l}\text { P1096 (2), P1080 (1) } \\
\text { MO (1), PE (3) }\end{array}$ & $\begin{array}{l}\text { Mid-continent orogenies (Lovell, 2013; Park et al., } \\
\text { 2010) }\end{array}$ \\
\hline Older than 2250 Ma & P1080 (1), MO (2) & $\begin{array}{l}\text { Undectected provinces of the Canadian Shield (Lovell, } \\
\text { 2013); African Archean Terrane (Heatherington and } \\
\text { Dueller, 1999; Schofield and Gullespie, 2007) }\end{array}$ \\
\hline African 1500-1900 Ma & $\begin{array}{l}\text { P382 (8), P383 (7) } \\
\text { FMG (2), STPB (1) }\end{array}$ & $\begin{array}{l}\text { Birimian Basement of the West African Craton (1700- } \\
\text { 2000 Ma; Villeneuve, 2008). Amazonian granitoid } \\
\text { production 1500-1900 Ma (Condi et al., 2009) }\end{array}$ \\
\hline
\end{tabular}

\subsection{Geospatial Trends in Norphlet Composition}

From the five samples (11 thin-sections from various depths) point-counted, several trends are observed. There are few to no volcanic rock fragments within the samples, the amount of plagioclase is largest within the Florida Panhandle and decreases to the south/southeast, and there is little to no sedimentary lithics in the Florida Panhandle but sedimentary lithic abundance increases to the south/southeast.

On the QtFL and QmFLt diagrams (Fig. 56) all samples plot either as craton interior, transitional continental, and quartzose recycled provenance and show no evidence of magmatic arc. Minor amounts of volcanic rock fragments in the Apalachicola Embayment samples coincides with previous interpretations of this region as an area of extension and rifted basement (Salvador, 1987; Dobson and Buffler, 1997). The few volcanic grains in samples OSCG-6396 and OCS-G-6406 are due to rift-related magmatism that was occurring in Florida and Georgia during the Mesozoic (Fig 6; Chowns and Williams, 1983; Arthur, 1988; Heatherington and Mueller, 2003). 

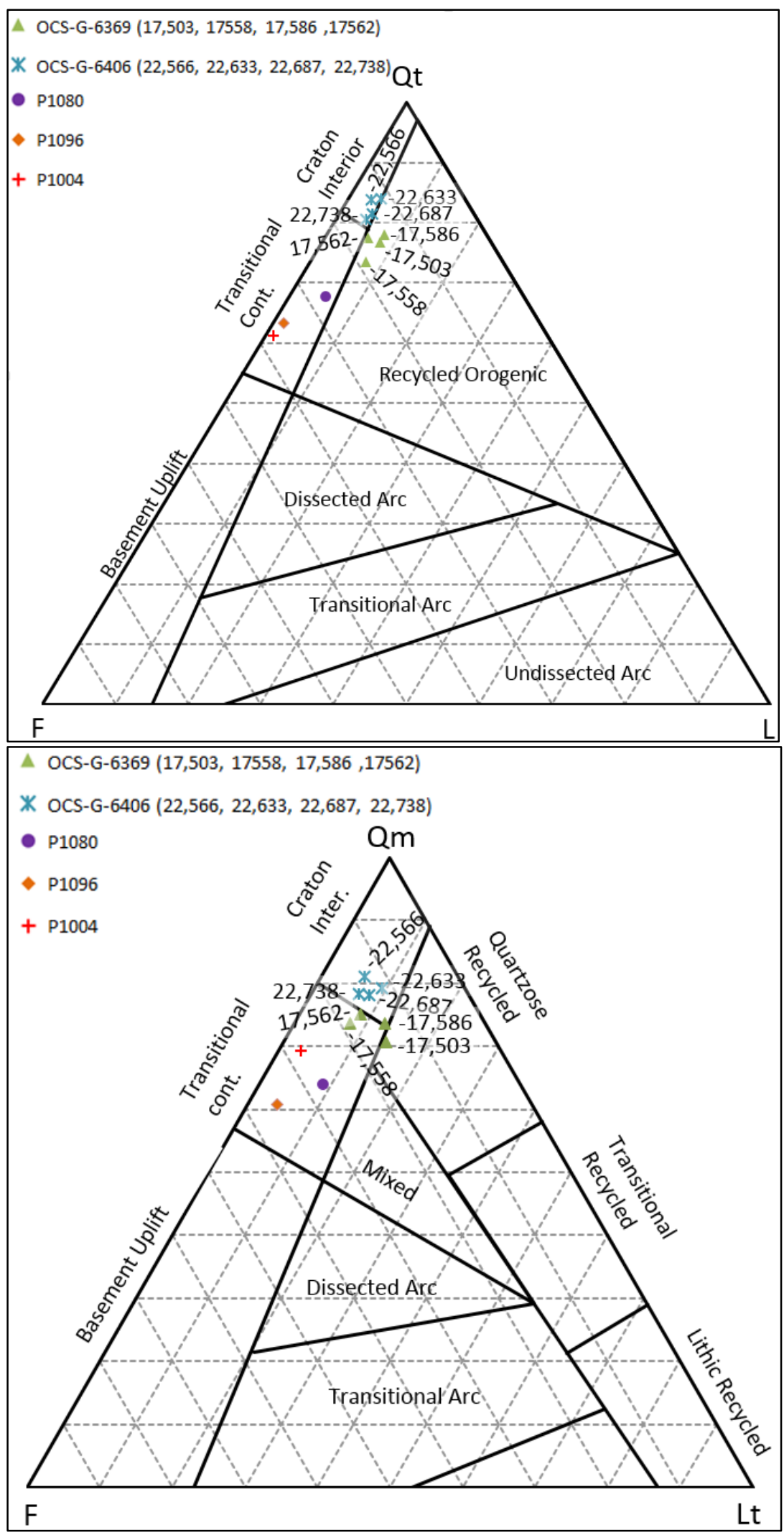

Figure 56. QtFL and QmFLt plots of the eolian facies of the Norphlet Formation after Dickinson, 1979. The ternary plots are used to determine the tectonic setting from which the sediments were derived. All samples plot as continental block and recycled orogenies. 

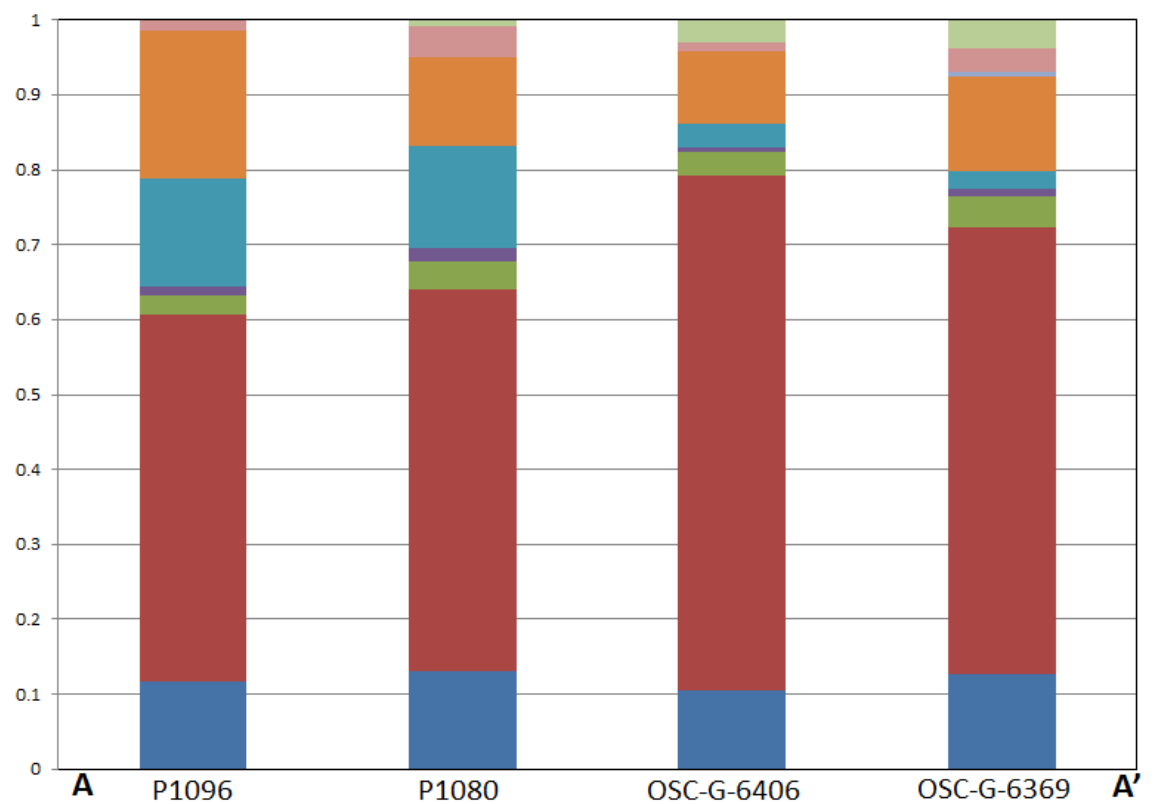

Figures 57 and $\approx \mathrm{Fk}$ apu - Fpt ap ramu abundance of

plagioclase from the

Florida Panhandle

(P1096 and P1080) to

Destin Dome (OCS-G-

6406) and Pensacola

Figure 58. Relative abundances of framework grains for the eolian facies of the Norphlet Formation from cross-section in Figure 58.

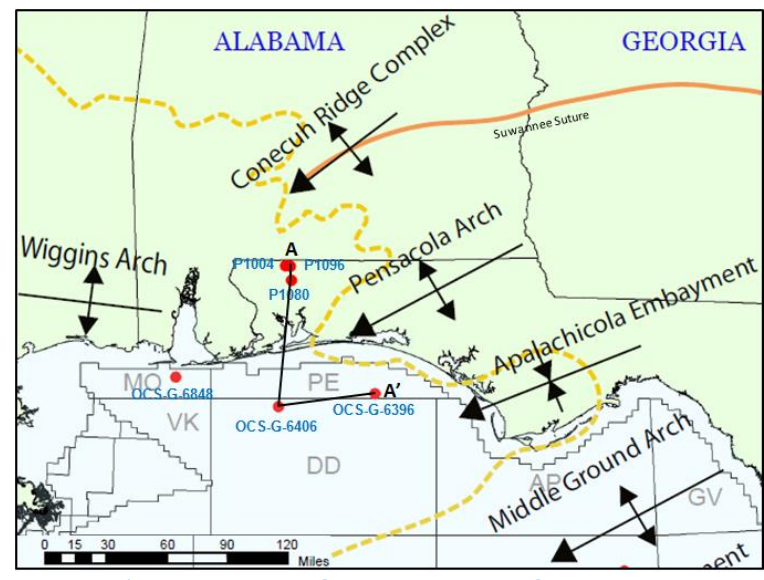

Figure 57. Location of cross-section for Figure 47.
(OCS-G-6396), from the north side of the

Pensacola Arch around the west to the south side of the arch, respectively. The Destin Dome and

Pensacola samples have a high quartz content and a high ratio of orthoclase to plagioclase (3:1 on average). This is indicative of a cratonic source with low relief, long-term weathering and

transport (Dickinson and Suczek, 1979). The Florida Panhandle samples have a lower quartz content with greater amounts of total feldspar characterized by roughly equal orthoclase and plagioclase. The arkosic (e.g. Folk, 1980) nature and proximal position to the Pensacola Arch of these samples indicate an uplifted basement source where relief is high and erosion is rapid (Dickinson and Suczek, 1979). Sample P1080 which is more proximal to the Pensacola Arch has 
a more immature texture than the other Florida samples, P1096 and P1004, having coarser, less well sorted, and more angular grains.

There is a shift within the samples from predominantly metamorphic rock fragments in the Florida Panhandle (P1004, P1096, and P1080) to predominantly sedimentary rock fragments in the Destin Dome sample (OCS-G-6406) to roughly equal metamorphic and sedimentary rock fragments in the Pensacola sample (OCS-G-6396; Fig. 59). This could show a difference in provenance of the Destin Dome and Pensacola samples as opposed to the Florida samples. Possible sources for sedimentary rock fragments in the Destin Dome sample (OCS-G6406) include both Laurentia and Gondwana based on the U-Pb detrital zircon data. However, due to the larger percentage of sedimentary rock fragments updip in the Pensacola sample (OCS-G-6396), it is possible that more sedimentary rock fragments are being input from Gondwana then Laurentia. 


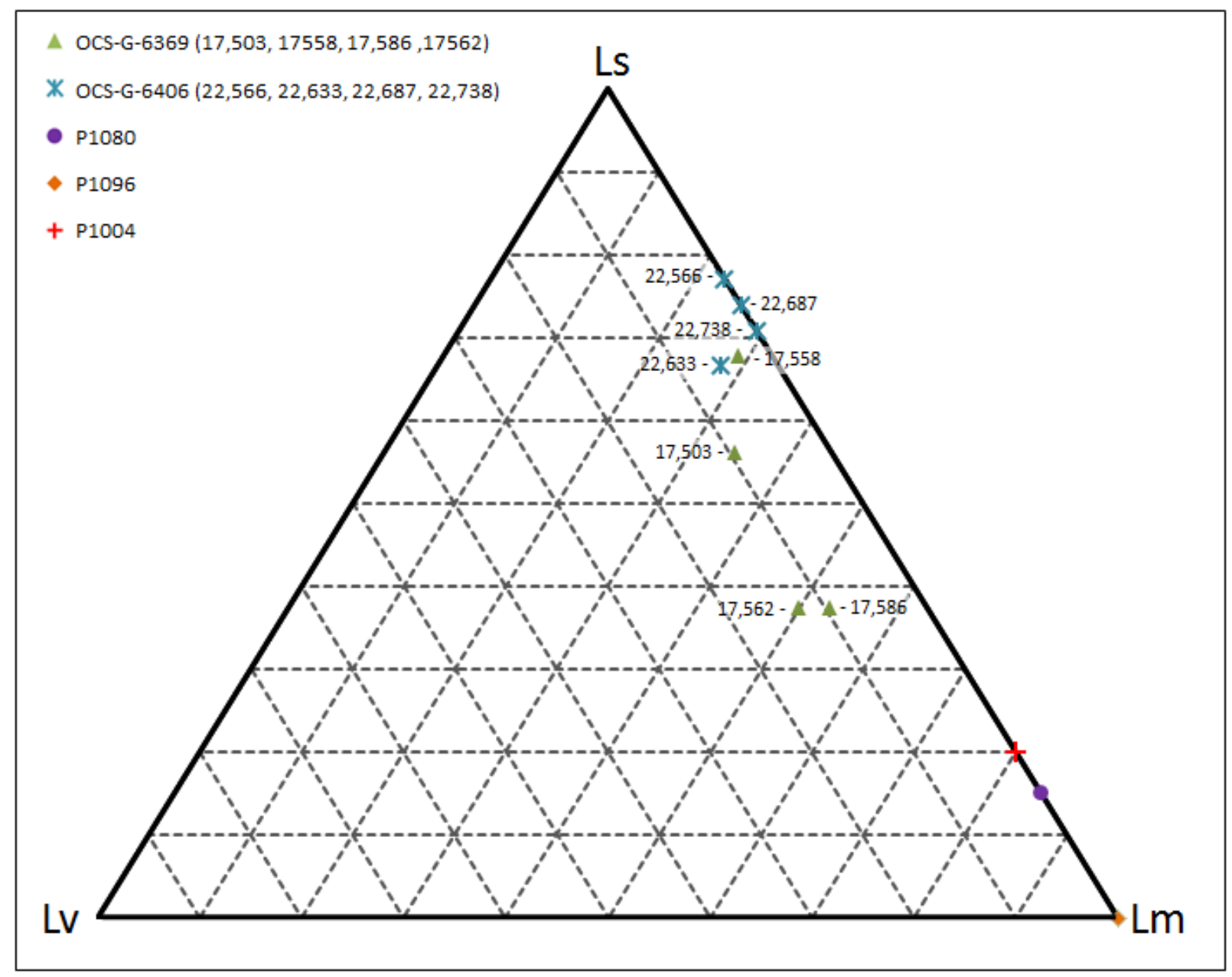

Figure 59. LsLmLv plot showing the relative abundances of lithic rock fragments (sedimentary, metamorphic, and volcanic) of the eolian facies of the Norphlet Formation. 


\subsection{Geospatial Trends in Dense Mineral Abundances}

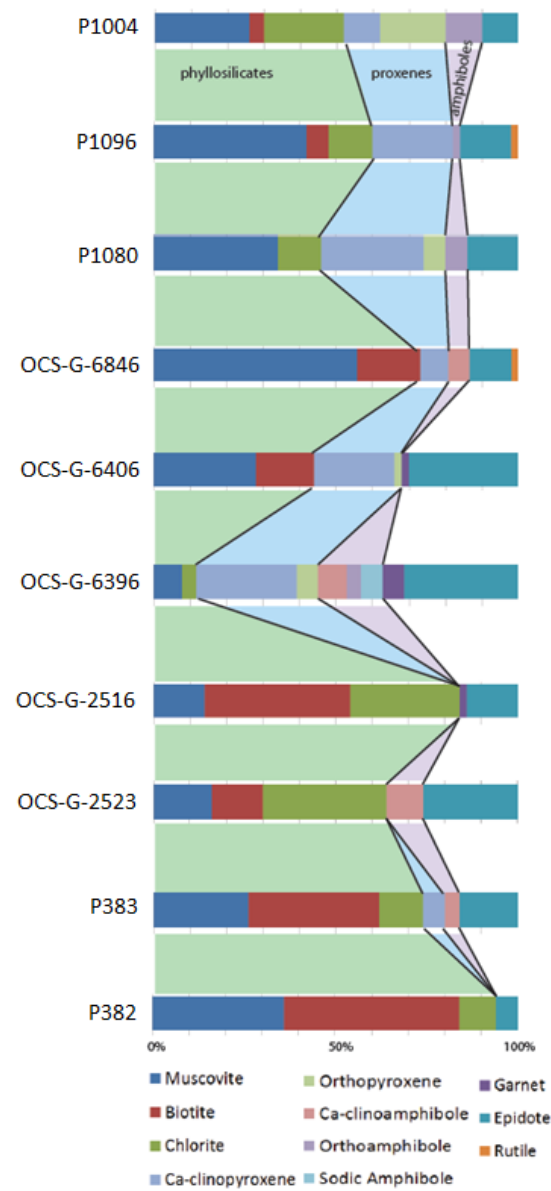

Figure 61. Abundances of dense minerals within the samples.

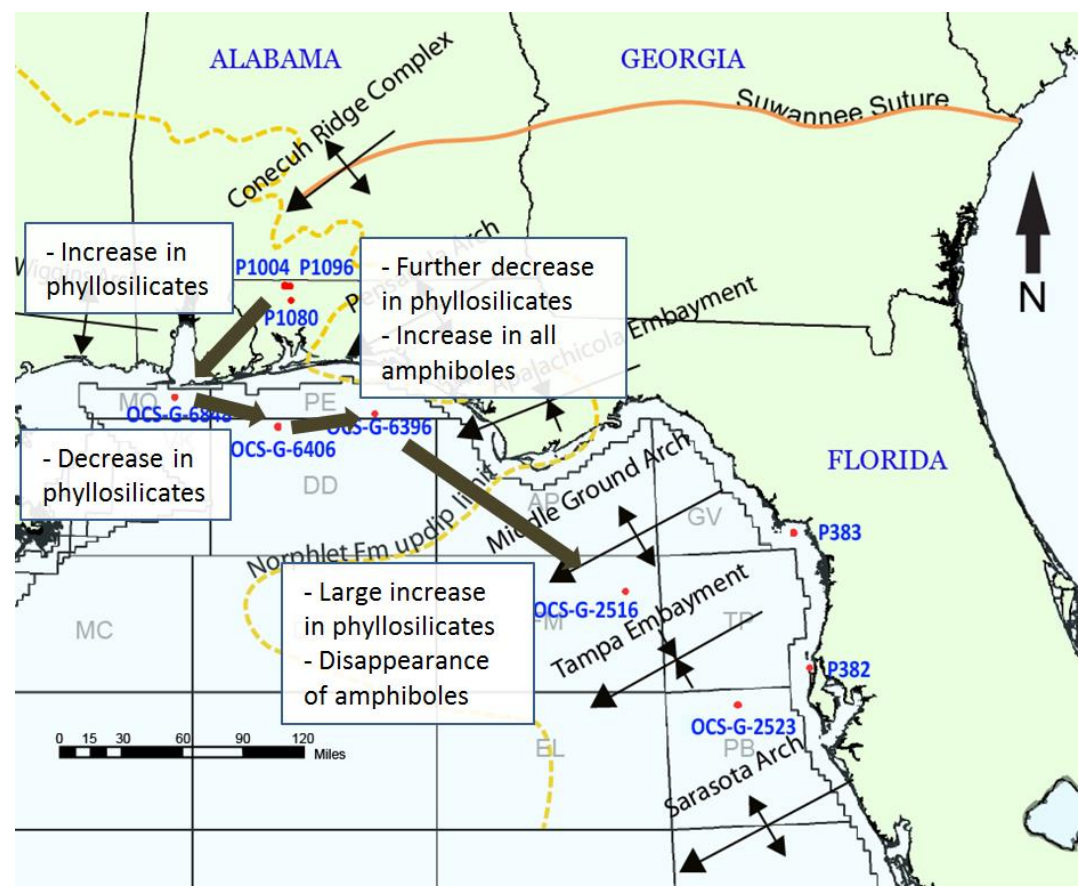

Figure 60. Geospatial trends in dense mineral abundances within the study.

Geospatial trends in dense mineral abundances can be

observed from the north side of the Pensacola Arch, around

the west to the southern side of the arch and down to the

southeastern GOM samples (Fig. 60 and 61). The dense minerals in the Florida Panhandle are

predominantly phyllosilicates, averaging $53 \%$ and an average of $25 \%$ pyroxene and $6 \%$

amphibole. Moving westward away from the arch to the Mobile Bay sample there is an

increase in phyllosilicates to $73 \%$ and a decrease in pyroxenes. This is likely due to the

proximity of the Wiggins Arch which consists largely of phyllite. Moving toward the southern

side of the arch at sample OCS-G-6406 there is decrease in phyllosilicates and again a slight

increase in pyroxenes. Further into the Apalachicola Embayment at sample OCS-G-6396 there

is a further drop in phyllosilicates and major increase in chain silicates. This likely coincides with 
the proximity to volcanic activity occurring during the Triassic. Lastly, shifting toward the southeastern samples there is another increase in phyllosilicates and drop in chain silicates.

\section{Provenance Scenario}

Geospatial trends in $\mathrm{U}-\mathrm{Pb}$ detrital zircon geochronology, sandstone composition, and heavy mineral abundances have allowed for the identification of four petrofacies. These petrofacies of similar source affinity have been identified based on similar U-Pb age populations, petrology, and dense mineral abundances and include primarily Laurentiansourced, mixed Laurentian- and Gondwanan-sourced, primarily Gondwanan-sourced, and entirely Gondwanan-sourced (Fig. 62).

\subsection{Primarily Laurentian Affinity: Mobile Bay}

Only the Mobile Bay sample (OCS-G-6848) was primarily sourced by Laurentia. The largest U-Pb population in this sample is Grenville (900-1300 Ma), similar to what was seen in the Park et al. (2010) data from the Appalachian foreland basin. The second largest zircon population is coeval with the Appalachain Mountain building events (Taconic, 430-480 Ma, Acadian, 374-425 Ma, and Alleghanian, 280-325 Ma). These ages make up the majority (74\%) of this sample. Other Laurentian sources identified in this sample of lower abundance include the Granite-Rhyolite (1300-1500 Ma) and Yavapai-Mazatzal (1600-1800 Ma) Provinces. The smallest population in this sample is Gondwanan with very few U-Pb dates that indicate PanAfrican (6; 500-680 Ma) and Trans-Amazonian/Eburnean (1; 1900-2250 Ma) sources. Because of the large contribution from the Appalachian hinterland and foreland basin and the near lack of Gondwanan ages, this sample is considered to be sourced primarily from Laurentia. 


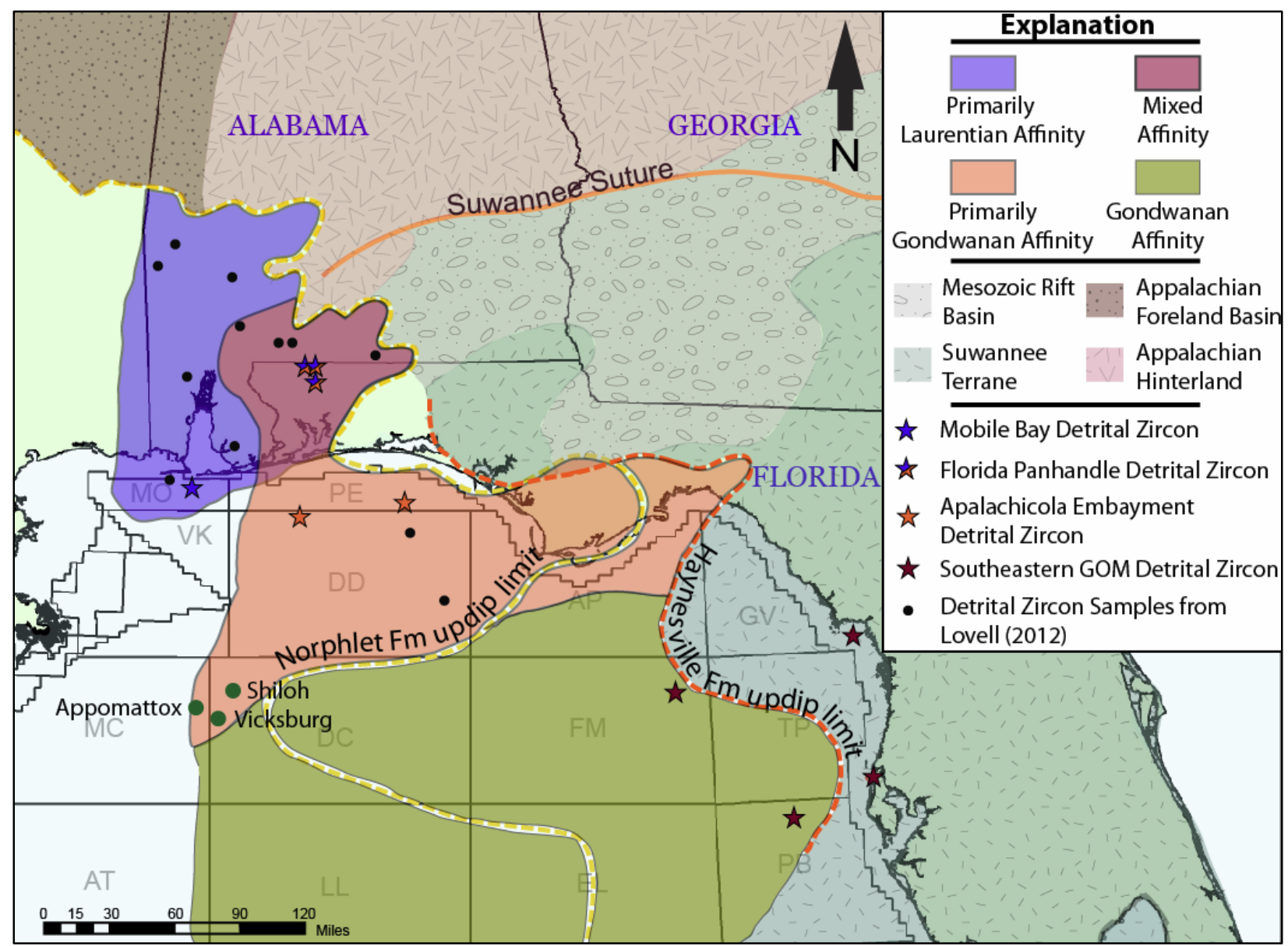

Figure 62. Petrofacies within the study area based on $\mathrm{U}-\mathrm{Pb}$ detrital zircon age distributions, thin-section petrography, and dense mineral analysis from this study as well as Lovell (2013). Primarily Laurentian-affinity indicated in blue have the largest Laurentian coeval U-Pb age distribution. Gondwanan-affinity indicated in green have near entirely Gondwanan coeval $\mathrm{U}-\mathrm{Pb}$ age distributions. Primarily Gondwanan-affinity indicated in orange have a larger amount of Gondwanan coeval U-Pb age distributions than Laurentian. Mixed affinity indicated in maroon have the larger Laurentian coeval $\mathrm{U}-\mathrm{Pb}$ age distributions but distinct Gondwanan coeval $\mathrm{U}$ $\mathrm{Pb}$ age distributions as well.

\subsection{Gondwanan Affinity: Southeastern Gulf of Mexico}

The samples from wells OCS-G-2516, OCS-G-2523, P383, and P382 have distinctly different $\mathrm{U}-\mathrm{Pb}$ age distributions than the Mobile Bay sample. The two major age populations in these samples correlate to the Pan-African (500-680 Ma) and Trans-Amazonian/Eburnean events (1900-2250 Ma). Major peaks in these samples occur around $550 \mathrm{Ma}$ and $620 \mathrm{Ma}$. These samples also lack any age population that correlate to Appalachian mountain building

(Taconic, Acadian, Alleghanian), Grenville, or the Laurentian Craton (with the exception of two 
grains in sample OCS-G-2516). Less influential sources in these samples include the

Gondwanan Sunsas/Central and South Africa orogenies which occurred between 950-1500 Ma and the African Archaen Terrane. Due to the lack of any Appalachian populations and large influence of the Pan-African and Trans-Amazonian/Eburnean events, these samples are considered to be sourced nearly entirely from Gondwana.

\subsection{Mixed Affinity: Florida Panhandle}

Samples P1004, P1096, and P1080 show an influence of both Laurentian and

Gondwanan sources. The Laurentian influence appears stronger with the largest U-Pb age density belonging to the Grenville event (900-1300 Ma) in all three samples. However, due to the proximity of the sample location to the Carolina Terrane (Peri-Gondwana), some of the dates may actually belong to the Gondwanan Sunsas/Central and South Africa orogenies (9001500 Ma). Because the Gondwanan Sunsas/Central and South Africa orogenies are a small signature in even the Gonwanan basement, it is likely that most of the $900-1300$ Ma ages in samples P1004, P1096, and P1080 were derived from the Grenville rocks of Laurentia. Other Laurentian events identified in these samples include the Appalachain orogen, Granite-Ryholite Province (1300-1500 Ma), and the Yavapai-Mazatzal (1600-1800 Ma) Province. The Gondwanan source includes age populations that correlate with the Pan-African (500-680 Ma) and Trans-Amazonian/Eburnean (1900-2250 Ma) events. These two sources are much more apparent in samples P1004, P1096, and P1080 than compared to the Mobile Bay sample.

\subsection{Primarily Gondwanan Affinity: Apalachicola Embayment}

Samples OCS-G-6406 and OCS-G-6396 have a large Gondwanan signature in their U-Pb age populations. The Pan-African (500-680 Ma) event has the greatest abundance of U-Pb ages 
and have peaks near $550 \mathrm{Ma}$ and $620 \mathrm{Ma}$ similar to the southeastern Gulf of Mexico wells (OCSG-2516, OCS-G-2523, P383, and P382). These samples also have a greater TransAmazonian/Eburnean (1900-2250 Ma) signature compared to the Mobile Bay and Florida Panhandle samples. However, some Laurentian influence is still apparent in age populations that correlate to the Alleghanian (280-325 Ma) and Taconic Orogeny (430-480 Ma). The Granite-Rhyolite (1300-1500 Ma) and Yavapai-Mazatzal (1600-1800 Ma) Province appear only in the Destin Dome well (OCS-G-6406). These two samples are also the only two samples that recorded the Triassic rifting event which correlates to the location of volcanism occurring along the Tallahasse graben (which created the Apalachicola Embayment). Only a few ages (1-2\%) belong to the African Archean Terrane (2450-3050 Ma).

\subsection{Geographic Extent of Petrofacies}

The extent of these petrofacies have been based upon the previous $\mathrm{U}-\mathrm{Pb}$ detrital zircon geochronology study by Lovell (2013) and by transport pathways identified through the correlation between source area from $\mathrm{U}-\mathrm{Pb}$ ages and lithology. Transport modes include fluvial, based on facies distribution (Hunt, 2012) and the location of Jurassic paleo-highs, and wind, based on vector resultants of Norphlet Formation dune dip meter data (Hunt, 2012) and regional paleo-wind studies (Parrish and Peterson, 1988). Figure 63 shows the primary fluvial transport pathways which are slightly modified from Hunt (2013) based on the larger shale volume (>0.6) identified within the Apalachicola Embayment from this study. 


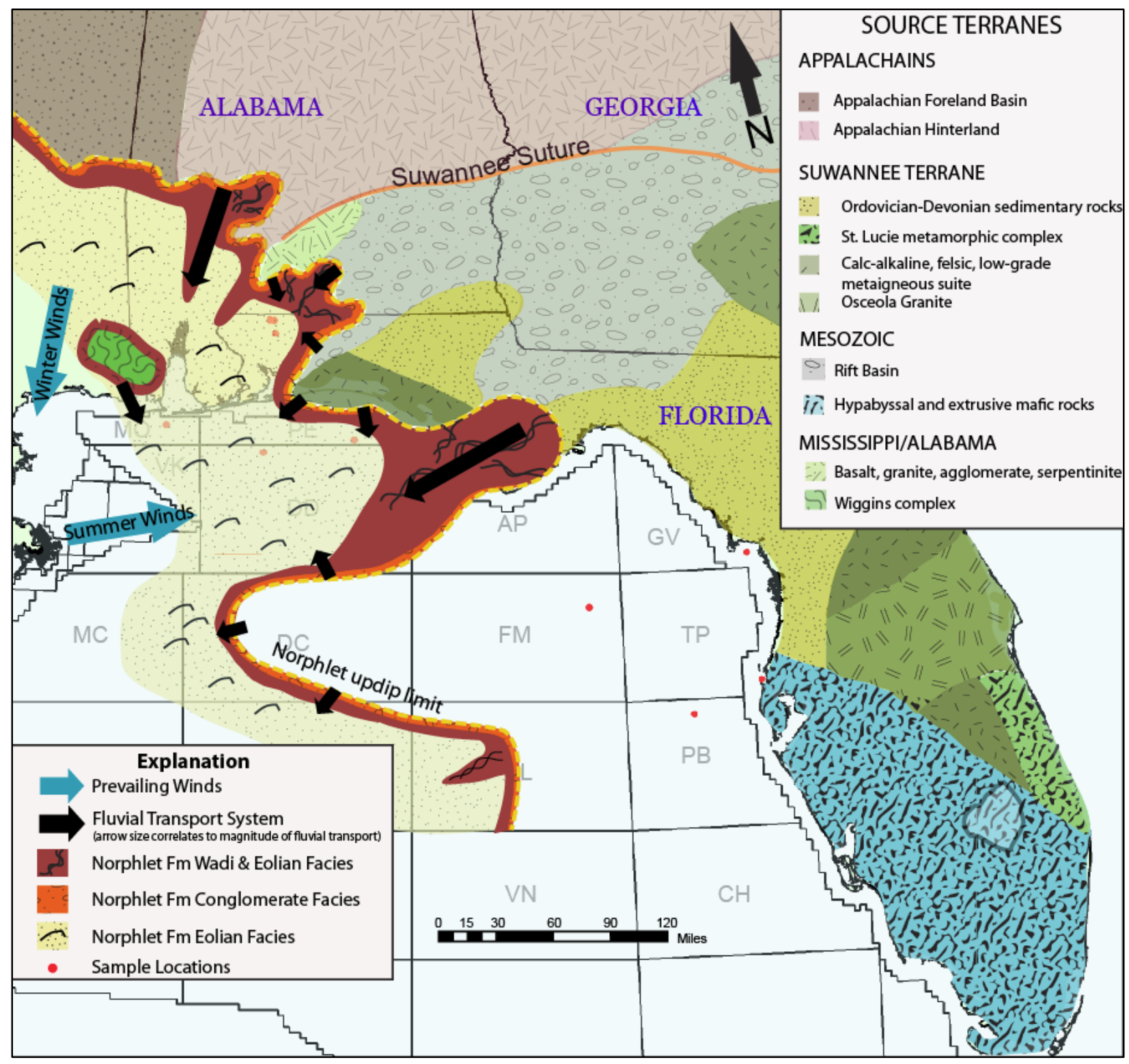

Figure 63. Paleogeographic map from provenance scenario that identifies four areas of similar sourcing. Extent of the conglomerate and wadi facies modified from Hunt (2012) based on U-Pb data and log-analysis. Prevailing winds from Parrish and Peterson (1988). 
Figure 64 shows the predicted wind patterns for North American during the latest Jurassic. In the study area, the late Jurassic summer winds were directed east and winter winds directed southwest (i.e., east-northeast and south-southwest presently). The influence of these winds on the Norphlet eolian facies is apparent in the vector resultants of the dune dip meter data (Fig. 65).

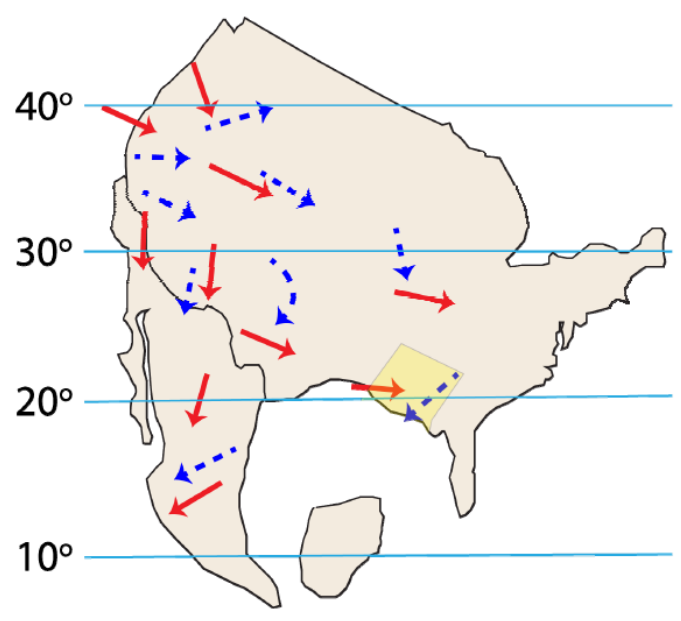

Figure 65. Paleo-wind patterns in North America in the latest Jurassic (Hunt, 2012 modified from Parrish and Peterson, 1988).

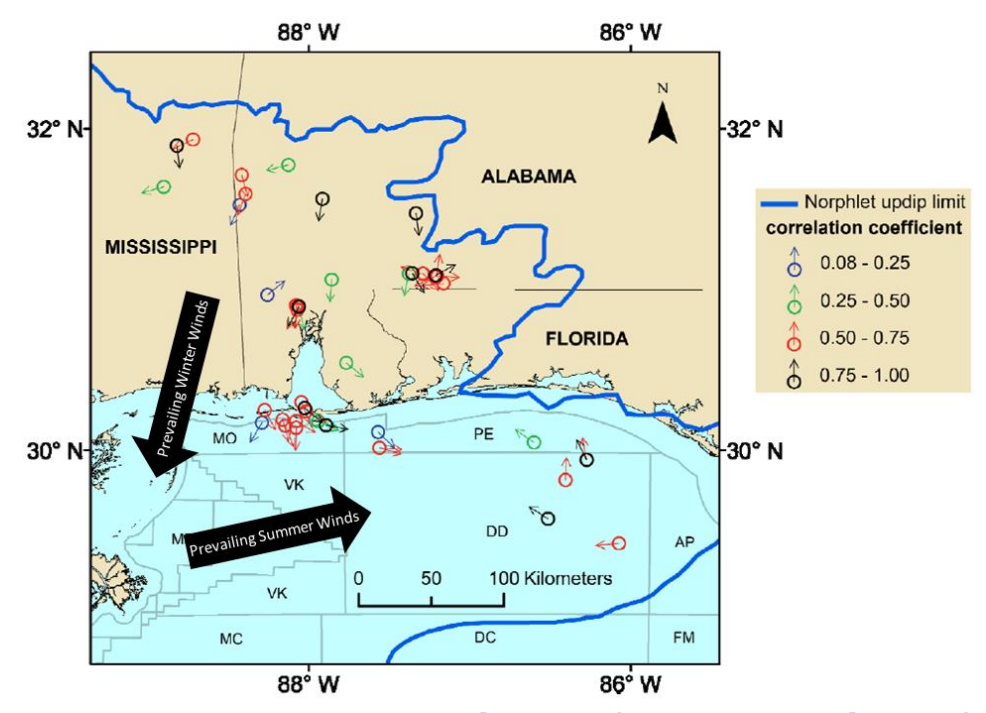

Figure 64. Dune migration direction from vector resultants of dip meter data from the Norphlet Formation (Modified from Hunt, 2012) with regional prevailing winds from Figure 56.

\section{Implications for Paleogeography}

Provenance data from this study along with previous paleogeographic studies of the Norphlet Formation show that the Norphlet was sourced from proximal paleo-highs and transported into the eolian system via alluvial fans and wadis. Changes in provenance are apparent in the $\mathrm{U}-\mathrm{Pb}$ data, sandstone composition, and dense mineral analysis. These proxies show a change in source from north of the Pensacola Arch (mixed affinity) around the west (Laurentian-affinity) and into the Apalachicola Embayment (Gondwanan-affinity). This supports the idea of a nearby source supplying sand to the Norphlet Formation. It also supports the idea 
that the paleo-highs acted as sediment barriers between the paleo-low depocenters as the Gondwanan-affinity signature is exclusively found to the south of the Pensacola Arch.

The magnitude of fluvial transport of the Norphlet Formation from the paleo-highs is interpreted from the lateral extent of the wadi facies. Hunt (2012) used well logs to determine the extent of wadi facies within the study area (Fig. 63). Certain geographic areas show a greater influence of fluvial transport via wadis such as in the Apalachicola Embayment. This region has the highest shale volume within the study area correlating to a greater amount of clay produced from water transport. Another area of abundant fluvial facies includes the north to south tract of wadi facies in southwestern Alabama. The length of the wadi facies tract in these two areas indicate that the source for sediment within the Apalachicola Embayment as well as Mobile Bay could be from much greater distances than surrounding areas such as the Conecuh Embayment.

The development of a large Norphlet erg system shows that this area was arid during the deposition of the Norphlet Formation. Once sediment entered the eolian system the prevailing wind directions controlled sediment dispersal. Prevailing seasonal wind patterns from Parrish and Peterson (1988) correlate with dip meter data of Norphlet dunes (Hunt, 2012) in southwest Alabama and the Mobile Bay offshore lease blocks (Fig. 64and 65). However, the dune dip meter data does not correlate with the prevailing winds within the Apalachicola Embayment. Because the dip meter data implies a west-northwest migration pattern, this could imply that the Apalachicola Embayment paleo-low channeled winter winds along the axis of the paleo-low. This occurrence is often seen in modern setting such as the Dead Sea wadis 
which channel east-southeast winds to the south along the axis of the valley (Shafir et al., 2008).

The combination of the overall fluvial and eolian transport direction and magnitude imply that the majority of the Norphlet Formation sand came from the north (Laurentian) and from the east (Gondwanan, via the Apalachicola Embayment). There is little evidence for a mixing zone similar to that of the Florida Panhandle where these two major sediment transport pathways meet. Samples from Mobile Bay and Destin Dome (OCS-G-6848 and OCS-G-6406) which are relatively close are still quite different from each other with regards to U-Pb distribution and composition. Because of this is it assumed that little mixing occurred between sediment from the north and the east. The lack of mixing is common in present erg systems such as the African Namib Sea where opposing south-southeast and north-northeast sand transport systems lead to deposition where sediments remain (Lancaster, 1995). These regions of converging eolian transport systems often correlate to a thickening of the deposits. This correlates with the greatest thickness of the Norphlet Formation occurring in the eastern Mobile Bay and western Destin Dome and Pensacola offshore lease blocks within the study area (Fig. 37).

The paleogeography for the Norphlet Formation in the EGOM can be used to infer sediment deposition for the clastic Haynesville Formation. Hunt (2012) performed U-Pb detrital zircon geochronology on the Haynesville Formation for four samples from the Mobile Bay, Pensacola, and Destin Dome offshore lease blocks and found similar results as Lovell's (2013) Norphlet study implying that sediment transport pathways remained similar from the deposition of the Norphlet Formation to the deposition of the Haynesville Formation. Similar to 
the Norphlet Formation, the Haynesville Formation was sourced from proximal paleo-highs creating an updip alluvial fan facies. Sediment was then further distributed along the axis of the paleo-lows. Because the Haynesville Formation lacks eolian sediments, transportation is predominantly fluvial, moving down dip. Downdip, sand facies grades into a shale facies which becomes more predominant (Dobson and Buffler, 1997). While Hunt (2012) found Laurentianaged zircon in his Haynesville Formation samples, the Haynesville Formation samples from the Florida Middle Ground and St. Petersburg offshore lease blocks, OCS-G-2516 and OCS-G-2523, in the Tampa Embayment, had no Laurentian-aged zircon and are inferred to be entirely sourced by the proximal Suwanne Terrane.

\section{Conclusions}

1. U-Pb analysis of 867 detrital zircon from 10 samples provided ages that are coeval with several possible source terranes and tectonic events. These include Pangean rifting (>250 Ma), Alleghanian (280-325 Ma), Acadian (374-425 Ma), Taconic (430-480 Ma), Pan-African (500-680 Ma), Mt. Rogers rifting (700-760 Ma), Grenville (900-1300), Sunsas and South and Central African Orogenies (950-1500 Ma), Granite-Rhyolite (1300-1500 Ma), Yavapai-Mazatzal (1600-1800 Ma), Trans-Amazonian/Eburnean (1900-2250), and African Archean Terrane (2450-3040 Ma). The U-Pb age distribution of these events within the samples allowed for the identification of four geochologic sources terranes which provided sediment to the Norphlet and surrounding formations. These include the Appalachian foreland basin, Appalachian hinterland, Mesozoic rift basin, and the Suwannee Terrane. 
2. Point counting of 11 thin-sections from the Florida Panhandle (P1004, P1096, and P1080) and Apalachicola Embayment (OCS-G-6406 and OCS-G-6396) samples determined the Norphlet to consist of arkose and subarkose, respectively. The average modal abundance from the Florida Panhandle samples is $\mathrm{Q}_{64} \mathrm{~F}_{33} \mathrm{~L}_{3}$. The Apalachicola Embayment samples are more compositionally mature with average modal abundances of $\mathrm{Q}_{79} \mathrm{~F}_{15} \mathrm{~L}_{6}$.

3. Four areas of source affinity are identified based on $\mathrm{U}-\mathrm{Pb}$ detrital zircon geochronology, sandstone petrology, and dense mineral analysis. These include the Mobile Bay offshore lease block which has a primarily Laurentian-affinity, the Apalachicola Embayment which has a primarily Gondwanan-affinity, the western Florida Panhandle which has a mixed affinity, and the southeastern Gulf of Mexico which has an entirely Gondwanan-affinity. The primarily and entirely Gondwanan-affinity regions are projected into the DeSoto and Mississippi Canyon offshore lease blocks indicating that the eolian sediment of the major Norphlet hydrocarbon discoveries, Shiloh, Vicksburg, and Appomatox, were sourced from the Suwannee Terrane.

4. Two major directions of sediment transport pathways are identified in the study area, both fluvial and eolian, were determined from the extent of wadi facies and dune dip data, respectively. In southwestern Alabama the major sediment transport pathway is south into the Mobile Bay offshore lease block. Within the Apalachicola Embayment, the dominant sediment transport pathway is west-northwest. Because the Apalachicola Embayment was a major sediment transport pathway that channeled paleowind during the deposition of the Norphlet Formation, the extent of the primarily Gondwanan- 
affinity region reaches into the DeSoto and Mississippi Canyon offshore lease blocks. This is supported by the similarity between the Destin Dome and Pensacola samples which are approximately 60 miles apart. The similarity exists in all provenance data, including $\mathrm{U}-\mathrm{Pb}$ age distributions, dense mineral analysis, and sandstone petrology.

5. The higher shale volume along with the presence of wadi and shale facies within the Apalachicola Embayment also suggests it was a major fluvial transport pathway during the Norphlet deposition.

6. The difference in provenance data from the north side of the Pensacola Arch around the west to south side of the arch suggests that the arch acted as a barrier to sediment transport. Sediments deposited within the northeast-southwest trending paleo-lows within the study area do not show mixing with each other.

7. The lack of mixing between the Mobile Bay and the western Destin Dome offshore lease block samples imply that when the two major transport pathways (south and westnorthwest) converge, sediment deposition occurred rather than mixing between the two areas. This region of convergence correlates to the thickest Norphlet deposition within the study area.

8. Paleogeography of the Haynesville Formation within the Tampa Embayment can be inferred from Norphlet Formation paleogeography. Similar to Norphlet Formation, the Haynesville Formation is sourced from proximal paleo-highs which, in the Tampa Embayment, is the Suwannee Terrane. Updip is an alluvial facies which grade into a fluvial facies channeled to the east-southeast by the Tampa Embayment which becomes more shaley downdip. 


\section{References}

Ajdukiewicz, J. M., P. H. Nicholson, and W. L. Esch, 2010, Prediction of deep reservoir quality using early diagenetic process models in the Jurassic Norphlet Formation, Gulf of Mexico: AAPG Bulletin, v. 94, no. 8, p. 1189-1227.

Andersen, T., 2005, Detrital zircons as tracers of sedimentary provenance: limiting conditions from statistics and numerical simulation: Chemical Geology, v. 216, no. 3-4, p. 249-270.

Arthur, J. D., 1988, Petrogenesis of Early Mesozoic Tholeiite in the Florida Basement and an Overview of Florida Basement Geology: Tallahssee, $40 \mathrm{p}$.

Becker, T. P., W. A. Thomas, S. D. Samson, and G. E. Gehrels, 2005, Detrital zircon evidence of Laurentian crustal dominance in the lower Pennsylvanian deposits of the Alleghanian clastic wedge in eastern North America: Sedimentary Geology, v. 182, no. 1-4, p. 59-86.

Bettencourt, J. S., W. B. Leite, A. S. Ruiz, R. Matos, B. L. Payolla, and R. M. Tosdal, 2010, The Rondonian-San Ignacio Province in the SW Amazonian Craton: An overview: Journal of South American Earth Sciences, v. 29, no. 1, p. 28-46.

Bureau of Ocean Energy Management, 2012a, Assessment of Technically Recoverable Hydrocarbon Resources of the Gulf of Mexico Outer Continental Shelf as of January 2009: $<$ http://www.data.boem.gov/homepg/data_center/paleo/paleo.asp> (accessed September 1, 2012).

Bureau of Ocean Energy Management, 2012b, Paleontologic Information: <http://www.data.boem.gov/homepg/data_center/paleo/paleo.asp> (accessed September 1, 2012).

Chowns, T. M., and C. T. Williams, 1983, Pre-Cretaceous rocks beneath the Georgia coastal plain - regional implications, in G. S. Gohn, ed., Studies related to the Charleston, South Carolina, earthquake of 1886 - tectonics and seismicity: USGS Professional Paper 1313 L, p. 42.

Claypool, G. E., and E. A. Mancinl, 1989, Geochemical Relationships of Petroleum in Mesozoic Reservoirs to Carbonate Source Rocks of Jurassic Smackover Formation, Southwestern Alabama ': AAPG Bulletin, v. 1, no. 1, p. 904-924.

Condie, K. C., E. Belousova, W. L. Griffin, and K. N. Sircombe, 2009, Granitoid events in space and time: Constraints from igneous and detrital zircon age spectra: Gondwana Research, v. 15 , no. 3-4, p. 228-242.

Culver, S. J., H. . Williams, and R. Venkatakrishnan, 1991, The Rokelide Orogen, in R. D. Dallmeyer, and J. P. Lecorche, eds., The West African Orogens and Circum-Atlantic Correlatives: Berlin, Springer, p. 124-150. 
Dallmeyer, R. D., 1987, 40Ar/39Ar age in detrital muscovite within Lower Ordovician sandstone in the coastal plain basement of Florida: Implications for west Africa terrane linkages: Geology, v. 15, p. 998-1001.

Dallmeyer, R. D., 1989, Contrasting accreted terranes in the southern Appalachian Orogen, basement beneath the Atlantic and Gulf Coastal Plains and West African orogens: Precambrian Research, v. 42, no. 3-4, p. 387-409.

Department of the Interior, 2008, Reasonably Foreseeable Development Scenario for Fluid Minerals: Florida: 43 p.

Dickinson, W. R., and C. A. Suczek, 1979, Plate Tectonics and Sandstone Compositions: AAPG Bulletin, v. 12, no. 12, p. 2164-2182.

Dobson, L. M., and R. T. Buffler, 1997, Seismic Stratigraphy and Geologic History of Jurassic Rocks , Northeastern Gulf of Mexico 1: AAPG Bulletin, v. 1, no. 1, p. 100-120.

Fedo, C. M., T. George, K. N. Sircombe, R. H. Rainbird, and B. Street, 2003, Detrital Zircon Analysis of the Sedimentary Record, in J. M. Hancher, and P. W. . Hoskin, eds., Zircon: Reviews in Mineralogy and Geochemistry: p. 277-303.

Folk, R. L., 1980, Petrology of Sedimentary Rocks: Austin, Hamilton Publishing, p. 184.

Gehrels, G., V. Valencia, and A. Pullen, 2006, NoDetrital Zircon Geochronology by Laser Ablation Multicollector ICPMS at the Arizona LaserChron Center, in T. Olszewski, ed., Geochronology: Emerging Opportunities: Paleontology Society Papers: p. 67-76.

Hartmann, L. A., 2002, The Mesoproterozoic Supercontinent Atlantica in the Brazilian Shield Review of Geological and U-Pb Zircon and Sm-Nd Isotopic Evidence: Gondwana Research, v. 5 , p. 157-163.

Heatherington, A.L, and P. A. Mueller, 1999, Lithospheric sources of North Florida, USA tholeiites and implications for the origin of the Suwannee terrane: Lithos, v. 46, no. 2, p. 215-233.

Heatherington, A.L., and P. A. Mueller, 2003, Mesozoic Igneous Activity in the Suwannee Terrane, Southeastern USA: Petrogenesis and Gondwanan Affinities: Gondwana Research, v. 6 , no. 2, p. 296-311.

Hibbard, J. P., E. F. Stoddard, D. T. Secor, and A. J. Dennis, 2002, The Carolina Zone : overview of Neoproterozoic to Early Paleozoic peri-Gondwanan terranes along the eastern Flank of the southern Appalachians: Earth-Science Reviews, v. 57, p. 299-339. 
Hoffman, P. F., 1999, The break-up of Rodinia, birth of Gondwana, true polar wander and the snowball Earth: Journal of African Earth Sciences, v. 28, no. 1, p. 17-33.

Hoskin, P. W. O., and U. Schaltegger, 2003, The Composition of Zircon and Igneous and Metamorphic Petrogenesis, in J. M. Hancher, and P. W. . Hoskin, eds., Zircon: Reviews in Mineralogy and Geochemistry: p. 27-62.

Hunt, B. W., 2012, Regional Norphlet Facies Correlation, Analysis and Implications for Paleostructure and Provenance, Eastern Gulf of Mexico: The University of Alabama, p. 112.

Ingersoll, R. V., T. F. Bullard, R. L. Ford, J. P. Grimm, and J. D. Pickle, 1984, The effect of grain size on detrital modes: a testof the Gazzi-Dickinson point-counting method: Journal of Sedimentary Petrology, v. 54, p. 103-116.

Lancaster, N., 1995, The geomorphology of desert dunes: New York, Routledge, p. 290.

Lovell, T., and A. Weislogel, 2010, Detrital Zircon U-Pb Age Constraints on the Provenance of the Late Jurassic Norphlet Formation, Eastern Gulf of Mexico : Implications for Paleogeography: Gulf Coast Association of Geological Societies Transactions, v. 60, p. 443460.

Lovell, T., 2013, Detrital Zircon U-Pb Age Constraints on the Provenance of the Upper Jurassic Norphlet Formation, Eastern Gulf of Mexico : The University of Alabama, p. 173.

Ludwig, K. R., 2012, A Geochronological Toolkit for Microsoft Excel Berkeley Geochronology Center Special Publication No. 5: p. 75.

Mancini, E. A., R. M. Mink, B. L. Bearden, and R. P. Wilkerson, 1985, Norphlet Formation (Upper Jurassic) of Southwestern and Offshore Alabama : Environments of Deposition and Petroleum Geology: AAPG Bulletin, v. 69, p. 881-898.

Mancini, E. A., B. H. Tew, and R. M. Mink, 1990, Jurassic Sequence Stratigraphy in the Mississippi Interior Salt Basin of Alabama: Gulf Coast Association of Geological Societies Transactions, v. 40, p. 521-530.

Marton, G. L., and R. T. Buffler, 1999, Jurassic-early cretaceous tectono-paleogeographic evolution of the southeastern gulf of Mexico basin, in A. D. Miall, ed., Sedimentary Basins of the World: Elsevier, p. 63-91.

MMS, 2001, The Promise of Deep Gas in the Gulf of Mexico: U.S. Department of the Interior: OCS Report, MMS 2001-037 p. 
Mueller, P. A., A.L. Heatherington, J.L. Wooden, R. D. Shuster, A. P. Nutman, and I. S. Williams, 1994, Precambrian zircons from the Florida basement : A Gondwanan connection:

Geology, v. 22, p. 119-122.

Oil \& Gas Journal, 2012, Shell, Nexen locate more oil in gulf Norphlet trend:

<http://www.ogj.com/articles/print/vol-110/issue-4a/general-interest/shell-nexen-locatemore.html> (accessed October 21, 2012).

Park, H., D. L. Barbeau Jr., A. Rickenbaker, D. Bachmann-Krug, and George Gehrels, 2010, Application of Foreland Basin Detrital-Zircon Geochronology to the Reconstruction of the Southern and Central Appalachian Orogen: The Journal of Geology, v. 118, no. 1, p. 23-44.

Parrish, J. T., and F. Peterson, 1988, Wind directions predicted from global circulation models and wind directions determined from eolian sandstones of the western United States $-A$ comparison: Sedimentary Geology, v. 56, no. 1-4, p. 261-282.

Pearson, O. N., 2011, Undiscovered Hydrocarbon Resources in the U.S. Gulf Coast Jurassic Norphlet and Smackover Formations: Gulf Coast Association of Geological Societies Transactions, v. 61, p. 329-340.

Van Der Plas, L., and A. C. Tobi, 1965, Point Counting prob.pdf: American Journal of Science, v. 263, p. 87-90.

Ridgway, J. G., 2010, Upper Jurassic (Oxfordian) Smackover Facies characterization at Little Cedar Creek Field, Conecuh County, Alabama: The University of Alabama, p. 129.

Salvador, A., 1987, Late Triassic-Jurassic Paleogeography and Origin of Gulf of Mexico Basin: AAPG Bulletin, v. 71, no. 4, p. 419-451.

Sassen, R., C. H. Moore, J. A. Nunn, F. C. Meendsen, and E. Heydari, 1987, Geochemical Studies of Crude Oil Generation, Migration, and Destruction in the Mississippi Salt Basin: Gulf Coast Association of Geological Societies Transactions, v. 37, p. 217-224.

Schofield, D. I., and M. R. Gillespie, 2007, A tectonic interpretation of "Eburnean terrane" outliers in the Reguibat Shield, Mauritania: Journal of African Earth Sciences, v. 49, no. 4-5, p. 179-186.

Scott, G. W., 1991, Petrology and provenance of the Norphlet Formation, Panhandle, Florida, in Florida Geological Survey, Information Circular no. 107: p. 89-121.

Shafir, H., F. J. Jin, Y. Lati, M. Cohen, and P. Alpert, 2008, Wind Channeling by the Dead-Sea Wadis: The Open Atmospheric Science Journal, v. 2, no. 1, p. 139-152. 
Steltenpohl, M. G., P. M. Mueller, Ann L. Heatherington, T. B. Hanley, and Joseph L. Wooden, 2008, Gondwanan/peri-Gondwanan origin for the Uchee terrane, Alabama and Georgia: Carolina zone or Suwannee terrane(?) and its suture with Grenvillian basement of the Pine Mountain window: Geosphere, v. 4, no. 1, p. 131.

Tew, B. H., R. M. Mink, S. D. Mann, B. L. Bearden, and E. A. Mancini, 1991, Geologic Framework of Norphlet and pre-Norphlet strata of the onshore and offshore eastern Gulf of Mexico area: Gulf Coast Association of Geological Societies Transactions, v. 41, p. 590-600.

Veevers, J. J., 2007, Pan-Gondwanaland post-collisional extension marked by 650-500 Ma alkaline rocks and carbonatites and related detrital zircons: A review: Earth-Science Reviews, v. 83, no. 1-2, p. 1-47.

Vermeesch, P., 2004, How many grains are needed for a provenance study?: Earth and Planetary Science Letters, v. 224, no. 3-4, p. 441-451.

Villeneuve, M., 2008, Review of the orogenic belts on the western side of the West African Craton: the Bassarides, Rokelides and Mauritanides: The boundaries of the West African Craton, v. Special Pu, p. 169-201.

Walls, I. A., 1985, Provenance of the Jurassic Norphlet Formation in southwestern Alabama: The University of Alabama, p. 143.

Wilson, L. K., 2011, The origin and development of the Tampa Embayment: Implications for the tectonic evolution of the eastern Gulf of Mexico: The University of Alabama, p. 63. 


\section{Appendices}

Appendix 1: Detrital Zircon U-Pb Isotopic Analysis

\begin{tabular}{|c|c|c|c|c|c|c|c|c|c|c|c|c|c|c|c|c|c|c|c|}
\hline Analysis & U & $206 \mathrm{~Pb}$ & $\begin{array}{c}\mathrm{U} / \mathrm{T} \\
\mathrm{h}\end{array}$ & $206 \mathrm{~Pb}^{*}$ & \pm & $207 \mathrm{~Pb}^{*}$ & \pm & $\underset{*}{206 \mathrm{~Pb}}$ & \pm & $\begin{array}{c}\text { erro } \\
\mathrm{r}\end{array}$ & $\underset{*}{206 \mathrm{~Pb}}$ & \pm & $\underset{*}{207 \mathrm{~Pb}}$ & \pm & $\underset{*}{206 \mathrm{~Pb}}$ & \pm & $\begin{array}{c}\text { Best } \\
\text { age }\end{array}$ & \pm & Conc \\
\hline & $\begin{array}{c}\text { (ppm } \\
)\end{array}$ & $204 \mathrm{~Pb}$ & & $207 \mathrm{~Pb}^{*}$ & $(\%)$ & $235 \mathrm{U}^{*}$ & $(\%)$ & $238 \mathrm{U}$ & $(\%)$ & corr. & $238 \mathrm{U}^{*}$ & (Ma) & $235 \mathrm{U}$ & (Ma) & $\underset{*}{207 \mathrm{~Pb}}$ & (Ma) & (Ma) & (Ma) & (\%) \\
\hline $1096-17$ & 95 & 17593 & 0.7 & $\begin{array}{r}20.025 \\
1 \\
\end{array}$ & $\begin{array}{r}10 . \\
2 \\
\end{array}$ & 0.3626 & $\begin{array}{r}10 . \\
4 \\
\end{array}$ & 0.0527 & 2.2 & 0.21 & 330.9 & 6.9 & 314.2 & 28.2 & 192.1 & 238.2 & 330.9 & 6.9 & NA \\
\hline 1096-14 & 404 & 60903 & 1.2 & $\begin{array}{r}19.058 \\
2 \\
\end{array}$ & 1.5 & 0.3943 & 2.7 & 0.0545 & 2.3 & 0.85 & 342.1 & 7.7 & 337.5 & 7.8 & 306.0 & 33.1 & 342.1 & 7.7 & NA \\
\hline $1096-75$ & 321 & 34760 & 2.3 & $\begin{array}{r}18.357 \\
0 \\
\end{array}$ & 1.5 & 0.4394 & 1.7 & 0.0585 & 1.0 & 0.55 & 366.5 & 3.4 & 369.8 & 5.4 & 390.7 & 32.6 & 366.5 & 3.4 & NA \\
\hline 1096-30 & 429 & 98507 & 4.5 & $\begin{array}{r}18.656 \\
4 \\
\end{array}$ & 1.0 & 0.4433 & 1.6 & 0.0600 & 1.2 & 0.77 & 375.5 & 4.4 & 372.6 & 4.9 & 354.3 & 22.5 & 375.5 & 4.4 & NA \\
\hline 1096-91 & 357 & 62899 & 8.1 & $\begin{array}{r}18.798 \\
0 \\
\end{array}$ & 2.7 & 0.4421 & 3.7 & 0.0603 & 2.5 & 0.67 & 377.3 & 9.1 & 371.7 & 11.5 & 337.2 & 62.1 & 377.3 & 9.1 & NA \\
\hline 1096-84 & 254 & 26167 & 1.1 & $\begin{array}{r}18.485 \\
1 \\
\end{array}$ & 1.7 & 0.4527 & 2.7 & 0.0607 & 2.0 & 0.75 & 379.8 & 7.4 & 379.2 & 8.4 & 375.1 & 39.3 & 379.8 & 7.4 & NA \\
\hline $1096-65$ & 68 & 17723 & 0.7 & $\begin{array}{r}18.478 \\
5 \\
\end{array}$ & $\begin{array}{r}14 . \\
6 \\
\end{array}$ & 0.4656 & $\begin{array}{r}17 . \\
1 \\
\end{array}$ & 0.0624 & 9.0 & 0.53 & 390.2 & 34.2 & 388.1 & 55.3 & 375.9 & 329.2 & 390.2 & 34.2 & NA \\
\hline $1096-4$ & 206 & $\begin{array}{r}11646 \\
7 \\
\end{array}$ & 1.2 & $\begin{array}{r}18.057 \\
1 \\
\end{array}$ & 1.5 & 0.5050 & 5.0 & 0.0661 & 4.7 & 0.95 & 412.8 & 19.0 & 415.1 & 16.9 & 427.6 & 32.9 & 412.8 & 19.0 & 96.6 \\
\hline $1096-43$ & 168 & 55424 & 1.4 & $\begin{array}{r}17.815 \\
6 \\
\end{array}$ & 2.8 & 0.5270 & 3.1 & 0.0681 & 1.2 & 0.40 & 424.7 & 5.0 & 429.8 & 10.7 & 457.6 & 62.1 & 424.7 & 5.0 & 92.8 \\
\hline $1096-29$ & 128 & 40267 & 1.5 & $\begin{array}{r}18.301 \\
1 \\
\end{array}$ & 3.8 & 0.5205 & 4.1 & 0.0691 & 1.6 & 0.39 & 430.6 & 6.7 & 425.5 & 14.3 & 397.6 & 84.8 & 430.6 & 6.7 & 108.3 \\
\hline $1096-49$ & 705 & $\begin{array}{r}18105 \\
1 \\
\end{array}$ & 2.9 & $\begin{array}{r}18.043 \\
3 \\
\end{array}$ & 1.0 & 0.5295 & 1.5 & 0.0693 & 1.1 & 0.76 & 431.9 & 4.8 & 431.5 & 5.3 & 429.3 & 21.7 & 431.9 & 4.8 & 100.6 \\
\hline $1096-41$ & 308 & 40466 & 1.2 & $\begin{array}{r}18.143 \\
9 \\
\end{array}$ & 1.2 & 0.5278 & 2.0 & 0.0695 & 1.5 & 0.79 & 432.9 & 6.5 & 430.3 & 6.9 & 416.9 & 27.0 & 432.9 & 6.5 & 103.8 \\
\hline 1096-22 & 258 & 76449 & 2.7 & $\begin{array}{r}18.284 \\
1 \\
\end{array}$ & 1.8 & 0.5242 & 2.2 & 0.0695 & 1.3 & 0.58 & 433.2 & 5.3 & 428.0 & 7.7 & 399.6 & 40.4 & 433.2 & 5.3 & 108.4 \\
\hline 1096-54 & 98 & 3276 & 2.8 & $\begin{array}{r}17.040 \\
9 \\
\end{array}$ & $\begin{array}{r}11 . \\
8 \\
\end{array}$ & 0.5679 & $\begin{array}{r}12 . \\
1 \\
\end{array}$ & 0.0702 & 2.7 & 0.22 & 437.3 & 11.3 & 456.7 & 44.6 & 555.3 & 258.5 & 437.3 & 11.3 & 78.8 \\
\hline $1096-23$ & 94 & 22841 & 1.0 & $\begin{array}{r}18.657 \\
9 \\
\end{array}$ & 5.6 & 0.5208 & 5.7 & 0.0705 & 1.4 & 0.24 & 439.0 & 5.7 & 425.7 & 19.9 & 354.1 & 125.6 & 439.0 & 5.7 & 124.0 \\
\hline 1096-15 & 77 & 18733 & 0.8 & $\begin{array}{r}17.930 \\
6 \\
\end{array}$ & 4.6 & 0.5665 & 4.9 & 0.0737 & 1.6 & 0.33 & 458.3 & 7.2 & 455.8 & 18.0 & 443.2 & 103.2 & 458.3 & 7.2 & 103.4 \\
\hline 1096-61 & 254 & 60146 & 1.0 & $\begin{array}{r}17.668 \\
7 \\
\end{array}$ & 2.2 & 0.5818 & 2.4 & 0.0746 & 0.9 & 0.36 & 463.5 & 3.8 & 465.6 & 8.9 & 475.9 & 49.5 & 463.5 & 3.8 & 97.4 \\
\hline $1096-46$ & 204 & 77026 & 2.5 & $\begin{array}{r}17.922 \\
8 \\
\end{array}$ & 2.0 & 0.5833 & 2.5 & 0.0758 & 1.5 & 0.59 & 471.1 & 6.7 & 466.5 & 9.4 & 444.2 & 45.2 & 471.1 & 6.7 & 106.1 \\
\hline $1096-47$ & 98 & 8764 & 1.4 & $\begin{array}{r}18.190 \\
7 \\
\end{array}$ & 6.9 & 0.5893 & 7.1 & 0.0778 & 1.7 & 0.24 & 482.7 & 7.9 & 470.4 & 26.7 & 411.1 & 154.3 & 482.7 & 7.9 & 117.4 \\
\hline 1096-11 & 393 & $\begin{array}{r}10737 \\
7 \\
\end{array}$ & 1.4 & $\begin{array}{r}17.679 \\
9 \\
\end{array}$ & 0.6 & 0.6097 & 0.9 & 0.0782 & 0.7 & 0.72 & 485.3 & 3.1 & 483.4 & 3.5 & 474.4 & 14.0 & 485.3 & 3.1 & 102.3 \\
\hline $1096-40$ & 100 & 3009 & 1.1 & $\begin{array}{r}17.373 \\
9 \\
\end{array}$ & 5.0 & 0.6227 & 5.3 & 0.0785 & 1.8 & 0.33 & 487.0 & 8.2 & 491.6 & 20.8 & 513.0 & 110.9 & 487.0 & 8.2 & 94.9 \\
\hline 1096-72 & 283 & $\begin{array}{r}20050 \\
5 \\
\end{array}$ & 0.8 & $\begin{array}{r}17.032 \\
1 \\
\end{array}$ & 1.6 & 0.7019 & 1.7 & 0.0867 & 0.8 & 0.45 & 536.0 & 4.0 & 539.9 & 7.3 & 556.5 & 33.8 & 536.0 & 4.0 & 96.3 \\
\hline $1096-56$ & 298 & 22095 & 1.0 & $\begin{array}{r}17.074 \\
0 \\
\end{array}$ & 2.6 & 0.7147 & 3.2 & 0.0885 & 1.9 & 0.59 & 546.7 & 10.0 & 547.6 & 13.6 & 551.1 & 56.5 & 546.7 & 10.0 & 99.2 \\
\hline 1096-59 & 122 & 28911 & 2.2 & $\begin{array}{r}16.973 \\
2 \\
\end{array}$ & 2.2 & 0.7505 & 2.4 & 0.0924 & 1.0 & 0.42 & 569.6 & 5.6 & 568.5 & 10.5 & 564.0 & 47.4 & 569.6 & 5.6 & 101.0 \\
\hline 1096-83 & 215 & 92329 & 0.9 & $\begin{array}{r}16.767 \\
1 \\
\end{array}$ & 1.1 & 0.7797 & 1.5 & 0.0948 & 1.1 & 0.70 & 584.0 & 5.9 & 585.3 & 6.8 & 590.6 & 23.6 & 584.0 & 5.9 & 98.9 \\
\hline $1096-76$ & 81 & 34313 & 1.6 & $\begin{array}{r}16.973 \\
2 \\
\end{array}$ & 3.4 & 0.7776 & 3.8 & 0.0957 & 1.6 & 0.44 & 589.3 & 9.3 & 584.1 & 16.8 & 564.0 & 74.3 & 589.3 & 9.3 & 104.5 \\
\hline 1096-39 & 16 & 5920 & 2.0 & $\begin{array}{r}16.874 \\
5 \\
\end{array}$ & $\begin{array}{r}21 . \\
0\end{array}$ & 0.7849 & $\begin{array}{r}21 . \\
5 \\
\end{array}$ & 0.0961 & 4.6 & 0.21 & 591.3 & 25.7 & 588.3 & 96.3 & 576.7 & 461.4 & 591.3 & 25.7 & 102.5 \\
\hline $1096-48$ & 55 & 15248 & 0.7 & $\begin{array}{r}15.983 \\
0 \\
\end{array}$ & 4.6 & 0.8468 & 4.9 & 0.0982 & 1.8 & 0.37 & 603.6 & 10.6 & 622.9 & 22.9 & 693.6 & 97.4 & 603.6 & 10.6 & 87.0 \\
\hline $1096-74$ & 192 & $\begin{array}{r}12431 \\
4 \\
\end{array}$ & 7.6 & $\begin{array}{r}16.232 \\
8 \\
\end{array}$ & 1.7 & 0.8711 & 1.8 & 0.1026 & 0.8 & 0.44 & 629.3 & 4.9 & 636.1 & 8.7 & 660.4 & 35.4 & 629.3 & 4.9 & 95.3 \\
\hline 1096-89 & 144 & 69993 & 1.2 & $\begin{array}{r}16.358 \\
9 \\
\end{array}$ & 2.6 & 0.8753 & 2.7 & 0.1039 & 0.7 & 0.26 & 636.9 & 4.3 & 638.4 & 12.7 & 643.8 & 55.4 & 636.9 & 4.3 & 98.9 \\
\hline 1096-73 & 106 & $\begin{array}{r}11974 \\
8 \\
\end{array}$ & 0.9 & $\begin{array}{r}16.127 \\
8 \\
\end{array}$ & 1.4 & 0.9768 & 2.1 & 0.1143 & 1.6 & 0.76 & 697.4 & 10.6 & 692.0 & 10.5 & 674.3 & 28.9 & 697.4 & 10.6 & 103.4 \\
\hline $1096-20$ & 38 & 55495 & 1.3 & $\begin{array}{r}14.207 \\
2 \\
\end{array}$ & 3.2 & 1.6015 & 3.8 & 0.1650 & 2.0 & 0.52 & 984.6 & 18.0 & 970.8 & 23.5 & 939.6 & 65.7 & 939.6 & 65.7 & 104.8 \\
\hline 1096-37 & 39 & 22325 & 1.9 & $\begin{array}{r}14.053 \\
0 \\
\end{array}$ & 3.1 & 1.5758 & 3.4 & 0.1606 & 1.3 & 0.40 & 960.1 & 12.0 & 960.7 & 20.9 & 962.0 & 62.9 & 962.0 & 62.9 & 99.8 \\
\hline 1096-38 & 61 & 40675 & 1.4 & $\begin{array}{r}13.891 \\
3 \\
\end{array}$ & 2.8 & 1.6545 & 3.1 & 0.1667 & 1.4 & 0.45 & 993.9 & 12.8 & 991.3 & 19.6 & 985.6 & 56.3 & 985.6 & 56.3 & 100.8 \\
\hline $1096-82$ & 72 & 42116 & 2.7 & $\begin{array}{r}13.846 \\
5\end{array}$ & 2.1 & 1.6635 & 2.3 & 0.1671 & 1.0 & 0.42 & 995.9 & 8.9 & 994.7 & 14.6 & 992.2 & 42.4 & 992.2 & 42.4 & 100.4 \\
\hline
\end{tabular}




\begin{tabular}{|c|c|c|c|c|c|c|c|c|c|c|c|c|c|c|c|c|c|c|c|}
\hline Analysis & U & $206 \mathrm{~Pb}$ & $\begin{array}{c}\mathrm{U} / \mathrm{T} \\
\mathrm{h}\end{array}$ & $206 \mathrm{~Pb}^{*}$ & \pm & $207 \mathrm{~Pb}^{*}$ & \pm & $\underset{*}{206 \mathrm{~Pb}}$ & \pm & $\begin{array}{c}\text { erro } \\
\mathrm{r}\end{array}$ & $\underset{*}{206 \mathrm{~Pb}}$ & \pm & $\underset{*}{207 \mathrm{~Pb}}$ & \pm & $\underset{*}{206 \mathrm{~Pb}}$ & \pm & $\begin{array}{c}\text { Best } \\
\text { age }\end{array}$ & \pm & Conc \\
\hline & $\begin{array}{c}(\mathrm{ppm} \\
)\end{array}$ & $204 \mathrm{~Pb}$ & & $207 \mathrm{~Pb}^{*}$ & (\%) & $235 \mathrm{U}^{*}$ & (\%) & $238 \mathrm{U}$ & (\%) & corr. & $238 \mathrm{U}^{*}$ & (Ma) & $235 \mathrm{U}$ & (Ma) & $\underset{*}{207 \mathrm{~Pb}}$ & $(\mathrm{Ma})$ & (Ma) & (Ma) & (\%) \\
\hline $1096-86$ & 43 & 56143 & 2.6 & $\begin{array}{r}13.760 \\
3 \\
\end{array}$ & 2.9 & 1.6529 & 4.3 & 0.1650 & 3.2 & 0.74 & 984.3 & 29.0 & 990.7 & 27.2 & 1004.8 & 58.9 & 1004.8 & 58.9 & 98.0 \\
\hline $1096-63$ & 27 & 39608 & 1.8 & $\begin{array}{r}13.733 \\
3 \\
\end{array}$ & 3.3 & 1.7263 & 3.5 & 0.1719 & 1.2 & 0.34 & 1022.8 & 11.3 & 1018.4 & 22.8 & 1008.8 & 67.7 & 1008.8 & 67.7 & 101.4 \\
\hline $1096-1$ & 246 & $\begin{array}{r}18020 \\
8 \\
\end{array}$ & 4.3 & $\begin{array}{r}13.725 \\
0 \\
\end{array}$ & 0.8 & 1.7540 & 2.2 & 0.1746 & 2.1 & 0.94 & 1037.4 & 20.0 & 1028.6 & 14.4 & 1010.0 & 15.6 & 1010.0 & 15.6 & 102.7 \\
\hline 1096-92 & 50 & $\begin{array}{r}11096 \\
7 \\
\end{array}$ & 2.4 & $\begin{array}{r}13.719 \\
9 \\
\end{array}$ & 2.4 & 1.7733 & 3.0 & 0.1765 & 1.7 & 0.58 & 1047.6 & 16.7 & 1035.7 & 19.3 & 1010.8 & 49.2 & 1010.8 & 49.2 & 103.6 \\
\hline $1096-97$ & 705 & $\begin{array}{r}56118 \\
0 \\
\end{array}$ & 13.3 & $\begin{array}{r}13.708 \\
1 \\
\end{array}$ & 0.5 & 1.6910 & 2.7 & 0.1681 & 2.6 & 0.99 & 1001.8 & 24.3 & 1005.1 & 16.9 & 1012.5 & 9.2 & 1012.5 & 9.2 & 98.9 \\
\hline $1096-88$ & 83 & 36779 & 2.5 & $\begin{array}{r}13.694 \\
3 \\
\end{array}$ & 1.7 & 1.7679 & 2.4 & 0.1756 & 1.6 & 0.69 & 1042.8 & 15.8 & 1033.8 & 15.3 & 1014.6 & 34.5 & 1014.6 & 34.5 & 102.8 \\
\hline $1096-13$ & 70 & 77808 & 1.7 & $\begin{array}{r}13.611 \\
1 \\
\end{array}$ & 1.7 & 1.7495 & 3.3 & 0.1727 & 2.9 & 0.87 & 1027.0 & 27.1 & 1027.0 & 21.3 & 1026.9 & 33.4 & 1026.9 & 33.4 & 100.0 \\
\hline $1096-50$ & 136 & $\begin{array}{r}17822 \\
8 \\
\end{array}$ & 2.4 & $\begin{array}{r}13.593 \\
6 \\
\end{array}$ & 1.4 & 1.7950 & 1.6 & 0.1770 & 0.8 & 0.49 & 1050.4 & 7.5 & 1043.6 & 10.4 & 1029.5 & 28.2 & 1029.5 & 28.2 & 102.0 \\
\hline $1096-8$ & 105 & 51376 & 1.5 & $\begin{array}{r}13.589 \\
2 \\
\end{array}$ & 1.5 & 1.8495 & 2.1 & 0.1823 & 1.5 & 0.72 & 1079.4 & 15.1 & 1063.2 & 13.9 & 1030.2 & 29.7 & 1030.2 & 29.7 & 104.8 \\
\hline 1096-53 & 58 & 47589 & 1.6 & $\begin{array}{r}13.586 \\
1 \\
\end{array}$ & 3.1 & 1.7685 & 3.5 & 0.1743 & 1.6 & 0.45 & 1035.5 & 15.1 & 1034.0 & 22.6 & 1030.6 & 63.0 & 1030.6 & 63.0 & 100.5 \\
\hline 1096-79 & 91 & 54150 & 1.9 & $\begin{array}{r}13.528 \\
9 \\
\end{array}$ & 1.2 & 1.8000 & 1.5 & 0.1766 & 0.9 & 0.63 & 1048.5 & 9.2 & 1045.5 & 9.8 & 1039.2 & 23.6 & 1039.2 & 23.6 & 100.9 \\
\hline $1096-3$ & 65 & $\begin{array}{r}10561 \\
2 \\
\end{array}$ & 1.3 & $\begin{array}{r}13.495 \\
6 \\
\end{array}$ & 2.2 & 1.8427 & 2.8 & 0.1804 & 1.8 & 0.65 & 1068.9 & 18.2 & 1060.8 & 18.7 & 1044.1 & 43.5 & 1044.1 & 43.5 & 102.4 \\
\hline 1096-19 & 98 & $\begin{array}{r}11994 \\
8 \\
\end{array}$ & 1.4 & $\begin{array}{r}13.481 \\
2 \\
\end{array}$ & 1.7 & 1.7958 & 2.9 & 0.1756 & 2.4 & 0.82 & 1042.8 & 23.0 & 1043.9 & 19.0 & 1046.3 & 33.5 & 1046.3 & 33.5 & 99.7 \\
\hline $1096-6$ & 251 & $\begin{array}{r}13249 \\
1 \\
\end{array}$ & 1.2 & $\begin{array}{r}13.440 \\
0 \\
\end{array}$ & 0.7 & 1.8303 & 2.0 & 0.1784 & 1.9 & 0.93 & 1058.3 & 18.2 & 1056.4 & 13.1 & 1052.5 & 14.5 & 1052.5 & 14.5 & 100.5 \\
\hline $1096-87$ & 261 & $\begin{array}{r}22362 \\
6 \\
\end{array}$ & 3.7 & $\begin{array}{r}13.439 \\
0 \\
\end{array}$ & 0.4 & 1.8264 & 0.9 & 0.1780 & 0.8 & 0.88 & 1056.1 & 7.7 & 1055.0 & 5.9 & 1052.6 & 8.6 & 1052.6 & 8.6 & 100.3 \\
\hline $1096-78$ & 86 & 41933 & 2.7 & $\begin{array}{r}13.320 \\
9 \\
\end{array}$ & 1.0 & 1.8742 & 1.4 & 0.1811 & 1.0 & 0.72 & 1072.8 & 10.1 & 1072.0 & 9.5 & 1070.4 & 20.0 & 1070.4 & 20.0 & 100.2 \\
\hline $1096-52$ & 206 & $\begin{array}{r}24355 \\
2 \\
\end{array}$ & 2.9 & $\begin{array}{r}13.292 \\
5 \\
\end{array}$ & 1.1 & 1.8886 & 1.9 & 0.1821 & 1.6 & 0.83 & 1078.3 & 16.1 & 1077.1 & 12.9 & 1074.7 & 21.6 & 1074.7 & 21.6 & 100.3 \\
\hline 1096-71 & 100 & $\begin{array}{r}10955 \\
6 \\
\end{array}$ & 2.1 & $\begin{array}{r}13.242 \\
9 \\
\end{array}$ & 1.6 & 1.8764 & 1.9 & 0.1802 & 1.1 & 0.56 & 1068.2 & 10.6 & 1072.8 & 12.7 & 1082.2 & 31.7 & 1082.2 & 31.7 & 98.7 \\
\hline 1096-55 & 131 & 87327 & 1.4 & $\begin{array}{r}13.242 \\
4 \\
\end{array}$ & 1.5 & 1.7613 & 4.1 & 0.1692 & 3.8 & 0.93 & 1007.5 & 35.2 & 1031.3 & 26.2 & 1082.3 & 29.5 & 1082.3 & 29.5 & 93.1 \\
\hline $1096-12$ & 713 & $\begin{array}{r}37250 \\
2 \\
\end{array}$ & 5.5 & $\begin{array}{r}13.213 \\
1 \\
\end{array}$ & 0.2 & 1.9300 & 1.5 & 0.1849 & 1.5 & 0.99 & 1094.0 & 15.2 & 1091.5 & 10.2 & 1086.7 & 4.5 & 1086.7 & 4.5 & 100.7 \\
\hline 1096-31 & 630 & $\begin{array}{r}49274 \\
0 \\
\end{array}$ & 80.8 & $\begin{array}{r}13.170 \\
9 \\
\end{array}$ & 0.3 & 1.9777 & 1.0 & 0.1889 & 0.9 & 0.94 & 1115.5 & 9.4 & 1107.9 & 6.6 & 1093.1 & 6.6 & 1093.1 & 6.6 & 102.1 \\
\hline 1096-64 & 136 & $\begin{array}{r}15055 \\
1 \\
\end{array}$ & 1.2 & $\begin{array}{r}12.988 \\
7 \\
\end{array}$ & 1.1 & 2.0178 & 1.4 & 0.1901 & 0.8 & 0.59 & 1121.8 & 8.4 & 1121.5 & 9.4 & 1121.0 & 22.2 & 1121.0 & 22.2 & 100.1 \\
\hline 1096-95 & 34 & 27736 & 1.6 & $\begin{array}{r}12.889 \\
0 \\
\end{array}$ & 4.5 & 2.0766 & 4.6 & 0.1941 & 1.0 & 0.22 & 1143.6 & 10.7 & 1141.1 & 31.7 & 1136.3 & 89.7 & 1136.3 & 89.7 & 100.6 \\
\hline 1096-35 & 193 & $\begin{array}{r}20804 \\
1 \\
\end{array}$ & 1.6 & $\begin{array}{r}12.870 \\
8 \\
\end{array}$ & 0.5 & 2.0512 & 1.3 & 0.1915 & 1.1 & 0.90 & 1129.4 & 11.7 & 1132.7 & 8.6 & 1139.1 & 10.9 & 1139.1 & 10.9 & 99.1 \\
\hline $1096-77$ & 51 & 45487 & 2.2 & $\begin{array}{r}12.848 \\
7 \\
\end{array}$ & 2.6 & 2.1647 & 4.6 & 0.2017 & 3.8 & 0.82 & 1184.6 & 41.2 & 1169.8 & 32.1 & 1142.5 & 52.0 & 1142.5 & 52.0 & 103.7 \\
\hline $1096-42$ & 107 & $\begin{array}{r}18665 \\
7 \\
\end{array}$ & 1.6 & $\begin{array}{r}12.775 \\
9 \\
\end{array}$ & 1.2 & 2.1777 & 2.3 & 0.2018 & 2.0 & 0.85 & 1184.9 & 21.5 & 1174.0 & 16.3 & 1153.8 & 24.4 & 1153.8 & 24.4 & 102.7 \\
\hline 1096-51 & 512 & $\begin{array}{r}12201 \\
1 \\
\end{array}$ & 2.0 & $\begin{array}{r}12.765 \\
0 \\
\end{array}$ & 0.4 & 1.7769 & 3.0 & 0.1645 & 3.0 & 0.99 & 981.8 & 27.4 & 1037.1 & 19.7 & 1155.5 & 7.2 & 1155.5 & 7.2 & 85.0 \\
\hline $1096-60$ & 16 & 16093 & 8.6 & $\begin{array}{r}12.751 \\
7 \\
\end{array}$ & 6.6 & 1.9519 & 7.7 & 0.1805 & 4.0 & 0.52 & 1069.8 & 39.6 & 1099.1 & 52.0 & 1157.5 & 131.5 & 1157.5 & $\begin{array}{r}131 . \\
5 \\
\end{array}$ & 92.4 \\
\hline 1096-32 & 77 & $\begin{array}{r}10320 \\
5 \\
\end{array}$ & 2.5 & $\begin{array}{r}12.693 \\
1 \\
\end{array}$ & 1.3 & 2.1398 & 3.1 & 0.1970 & 2.8 & 0.91 & 1159.1 & 29.5 & 1161.8 & 21.2 & 1166.7 & 25.3 & 1166.7 & 25.3 & 99.4 \\
\hline 1096-57 & 154 & 75144 & 2.3 & $\begin{array}{r}12.685 \\
6 \\
\end{array}$ & 0.7 & 2.2610 & 1.6 & 0.2080 & 1.4 & 0.89 & 1218.3 & 15.7 & 1200.2 & 11.3 & 1167.8 & 14.8 & 1167.8 & 14.8 & 104.3 \\
\hline $1096-36$ & 43 & 39270 & 2.2 & $\begin{array}{r}12.664 \\
4 \\
\end{array}$ & 3.3 & 2.1215 & 3.6 & 0.1949 & 1.5 & 0.41 & 1147.7 & 15.5 & 1155.8 & 25.0 & 1171.2 & 65.7 & 1171.2 & 65.7 & 98.0 \\
\hline $1096-45$ & 181 & $\begin{array}{r}15874 \\
7 \\
\end{array}$ & 1.7 & $\begin{array}{r}12.372 \\
1 \\
\end{array}$ & 0.9 & 2.3877 & 1.3 & 0.2143 & 1.0 & 0.74 & 1251.4 & 11.3 & 1238.9 & 9.7 & 1217.3 & 17.9 & 1217.3 & 17.9 & 102.8 \\
\hline 1096-98 & 362 & 59051 & 3.3 & $\begin{array}{r}11.922 \\
3 \\
\end{array}$ & 0.6 & 2.4227 & 9.6 & 0.2095 & 9.6 & 1.00 & 1226.1 & $\begin{array}{r}107 . \\
5 \\
\end{array}$ & 1249.3 & 69.4 & 1289.7 & 12.4 & 1289.7 & 12.4 & 95.1 \\
\hline $1096-5$ & 304 & $\begin{array}{r}18055 \\
0 \\
\end{array}$ & 5.7 & $\begin{array}{r}11.795 \\
3 \\
\end{array}$ & 2.4 & 2.6348 & 8.3 & 0.2254 & 7.9 & 0.96 & 1310.3 & 94.1 & 1310.4 & 61.1 & 1310.5 & 46.2 & 1310.5 & 46.2 & 100.0 \\
\hline 1096-18 & 72 & 37943 & 1.8 & $\begin{array}{r}11.780 \\
5 \\
\end{array}$ & 1.1 & 2.7544 & 1.6 & 0.2353 & 1.1 & 0.72 & 1362.4 & 14.1 & 1343.3 & 12.0 & 1312.9 & 21.8 & 1312.9 & 21.8 & 103.8 \\
\hline $1096-100$ & 116 & 62240 & 0.8 & $\begin{array}{r}11.699 \\
4 \\
\end{array}$ & 0.6 & 2.7520 & 1.0 & 0.2335 & 0.9 & 0.83 & 1352.9 & 10.6 & 1342.6 & 7.8 & 1326.3 & 11.4 & 1326.3 & 11.4 & 102.0 \\
\hline $1096-67$ & 68 & 44205 & 1.5 & $\begin{array}{r}11.587 \\
3 \\
\end{array}$ & 1.3 & 2.7607 & 1.4 & 0.2320 & 0.6 & 0.42 & 1345.0 & 7.0 & 1345.0 & 10.4 & 1344.9 & 24.4 & 1344.9 & 24.4 & 100.0 \\
\hline $1096-2$ & 84 & 49348 & 1.3 & $\begin{array}{r}11.364 \\
4 \\
\end{array}$ & 0.8 & 2.9651 & 1.3 & 0.2444 & 1.0 & 0.79 & 1409.5 & 12.6 & 1398.7 & 9.6 & 1382.3 & 15.1 & 1382.3 & 15.1 & 102.0 \\
\hline $1096-21$ & 94 & $\begin{array}{r}14714 \\
9 \\
\end{array}$ & 2.4 & $\begin{array}{r}11.247 \\
4 \\
\end{array}$ & 0.6 & 3.0236 & 1.1 & 0.2466 & 0.9 & 0.85 & 1421.2 & 12.1 & 1413.6 & 8.6 & 1402.2 & 11.5 & 1402.2 & 11.5 & 101.4 \\
\hline
\end{tabular}




\begin{tabular}{|c|c|c|c|c|c|c|c|c|c|c|c|c|c|c|c|c|c|c|c|}
\hline Analysis & U & $206 \mathrm{~Pb}$ & $\begin{array}{c}\mathrm{U} / \mathrm{T} \\
\mathrm{h}\end{array}$ & $206 \mathrm{~Pb}^{*}$ & \pm & 207Pb* & \pm & $\underset{*}{206 \mathrm{~Pb}}$ & \pm & $\begin{array}{c}\text { erro } \\
\mathrm{r}\end{array}$ & $\underset{*}{206 \mathrm{~Pb}}$ & \pm & $\underset{*}{207 \mathrm{~Pb}}$ & \pm & $\underset{*}{206 \mathrm{~Pb}}$ & \pm & $\begin{array}{c}\text { Best } \\
\text { age }\end{array}$ & \pm & Conc \\
\hline & $\begin{array}{c}\text { (ppm } \\
\text { ) }\end{array}$ & $204 \mathrm{~Pb}$ & & $207 \mathrm{~Pb}^{*}$ & (\%) & $235 \mathrm{U}^{*}$ & (\%) & $238 \mathrm{U}$ & (\%) & corr. & $238 \mathrm{U}^{*}$ & (Ma) & $235 \mathrm{U}$ & (Ma) & $\underset{*}{207 \mathrm{~Pb}}$ & (Ma) & (Ma) & (Ma) & (\%) \\
\hline 1096-44 & 79 & 79067 & 1.7 & $\begin{array}{r}10.874 \\
5 \\
\end{array}$ & 0.7 & 3.2265 & 1.0 & 0.2545 & 0.7 & 0.71 & 1461.5 & 9.0 & 1463.5 & 7.5 & 1466.5 & 13.0 & 1466.5 & 13.0 & 99.7 \\
\hline 1096-85 & 122 & $\begin{array}{r}18342 \\
3 \\
\end{array}$ & 2.6 & $\begin{array}{r}10.449 \\
5 \\
\end{array}$ & 0.8 & 3.6632 & 3.7 & 0.2776 & 3.6 & 0.98 & 1579.4 & 50.5 & 1563.4 & 29.4 & 1541.8 & 15.1 & 1541.8 & 15.1 & 102.4 \\
\hline 1096-16 & 139 & $\begin{array}{r}49438 \\
8 \\
\end{array}$ & 2.2 & $\begin{array}{r}10.023 \\
6 \\
\end{array}$ & 0.5 & 4.1284 & 1.0 & 0.3001 & 0.8 & 0.87 & 1691.9 & 12.4 & 1659.9 & 7.8 & 1619.7 & 8.8 & 1619.7 & 8.8 & 104.5 \\
\hline $1096-68$ & 54 & 84753 & 0.9 & 9.0787 & 0.7 & 5.0109 & 1.4 & 0.3299 & 1.2 & 0.87 & 1838.1 & 19.1 & 1821.2 & 11.7 & 1801.8 & 12.5 & 1801.8 & 12.5 & 102.0 \\
\hline 1096-69 & 56 & 50719 & 0.8 & 8.6573 & 0.5 & 5.5646 & 0.8 & 0.3494 & 0.6 & 0.76 & 1931.7 & 10.3 & 1910.6 & 7.0 & 1887.8 & 9.6 & 1887.8 & 9.6 & 102.3 \\
\hline $1096-80$ & 154 & $\begin{array}{r}10894 \\
2 \\
\end{array}$ & 2.4 & 7.5209 & 0.6 & 6.8463 & 2.6 & 0.3734 & 2.6 & 0.98 & 2045.6 & 45.0 & 2091.7 & 23.3 & 2137.4 & 10.1 & 2137.4 & 10.1 & 95.7 \\
\hline
\end{tabular}

\begin{tabular}{|c|c|c|c|c|c|c|c|c|c|c|c|c|c|c|c|c|c|c|c|}
\hline Analysis & U & $206 \mathrm{~Pb}$ & $\begin{array}{c}\mathrm{U} / \mathrm{T} \\
\mathrm{h}\end{array}$ & $206 \mathrm{~Pb}^{*}$ & \pm & 207 $\mathrm{Pb}^{*}$ & \pm & $\underset{*}{206 \mathrm{~Pb}}$ & \pm & $\begin{array}{c}\text { erro } \\
\mathrm{r}\end{array}$ & $\underset{*}{206 \mathrm{~Pb}}$ & \pm & $\underset{*}{207 \mathrm{~Pb}}$ & \pm & $\underset{*}{206 \mathrm{~Pb}}$ & \pm & $\begin{array}{c}\text { Best } \\
\text { age }\end{array}$ & \pm & Conc \\
\hline & $(\mathrm{ppm}$ & $204 \mathrm{~Pb}$ & & $207 \mathrm{~Pb}^{*}$ & $(\%)$ & $235 \mathrm{U}^{*}$ & (\%) & $238 \mathrm{U}$ & (\%) & corr. & $238 \mathrm{U}^{*}$ & (Ma) & $235 \mathrm{U}$ & (Ma) & $\underset{*}{207 \mathrm{~Pb}}$ & (Ma) & (Ma) & (Ma) & (\%) \\
\hline $8304-84$ & 372 & 12015 & 1.4 & $\begin{array}{r}16.843 \\
2 \\
\end{array}$ & 1.3 & 0.6006 & 4.3 & 0.0734 & 4.1 & 0.95 & 456.4 & 18.1 & 477.6 & 16.4 & 580.7 & 28.3 & 456.4 & 18.1 & 78.6 \\
\hline $8304-60$ & 531 & 5095 & 0.7 & $\begin{array}{r}16.146 \\
7 \\
\end{array}$ & 1.4 & 0.6779 & 2.1 & 0.0794 & 1.5 & 0.73 & 492.5 & 7.3 & 525.5 & 8.6 & 671.8 & 30.7 & 492.5 & 7.3 & 73.3 \\
\hline $8304-94$ & 431 & 6472 & 0.8 & $\begin{array}{r}16.608 \\
3\end{array}$ & 1.4 & 0.6684 & 2.6 & 0.0805 & 2.2 & 0.84 & 499.2 & 10.6 & 519.8 & 10.7 & 611.1 & 30.9 & 499.2 & 10.6 & 81.7 \\
\hline $8304-46$ & 307 & 3762 & 1.0 & $\begin{array}{r}16.501 \\
0\end{array}$ & 1.6 & 0.6763 & 2.5 & 0.0809 & 1.9 & 0.78 & 501.7 & 9.4 & 524.5 & 10.3 & 625.1 & 33.9 & 501.7 & 9.4 & 80.3 \\
\hline $8304-78$ & 54 & 14553 & 0.5 & $\begin{array}{r}16.275 \\
8\end{array}$ & 5.6 & 0.7197 & 5.8 & 0.0850 & 1.4 & 0.25 & 525.6 & 7.3 & 550.5 & 24.7 & 654.7 & 120.9 & 525.6 & 7.3 & 80.3 \\
\hline 8304-88 & 414 & 4447 & 0.8 & $\begin{array}{r}16.389 \\
8 \\
\end{array}$ & 1.9 & 0.7154 & 5.3 & 0.0850 & 4.9 & 0.94 & 526.2 & 24.8 & 548.0 & 22.2 & 639.7 & 40.0 & 526.2 & 24.8 & 82.2 \\
\hline $8304-77$ & 397 & $\begin{array}{r}11262 \\
2 \\
\end{array}$ & 3.4 & $\begin{array}{r}16.990 \\
3 \\
\end{array}$ & 0.9 & 0.6984 & 2.1 & 0.0861 & 1.9 & 0.90 & 532.2 & 9.5 & 537.8 & 8.6 & 561.8 & 19.6 & 532.2 & 9.5 & 94.7 \\
\hline 8304-37 & 84 & 28541 & 1.0 & $\begin{array}{r}17.245 \\
4 \\
\end{array}$ & 4.2 & 0.7047 & 4.3 & 0.0881 & 1.1 & 0.25 & 544.6 & 5.7 & 541.6 & 18.0 & 529.3 & 91.1 & 544.6 & 5.7 & 102.9 \\
\hline $8304-25$ & 112 & 65473 & 1.3 & $\begin{array}{r}17.050 \\
0 \\
\end{array}$ & 3.7 & 0.7138 & 3.8 & 0.0883 & 0.8 & 0.22 & 545.3 & 4.4 & 547.0 & 16.1 & 554.2 & 80.8 & 545.3 & 4.4 & 98.4 \\
\hline 8304-62 & 130 & 13461 & 0.8 & $\begin{array}{r}17.091 \\
2 \\
\end{array}$ & 2.6 & 0.7157 & 3.1 & 0.0887 & 1.7 & 0.54 & 548.0 & 8.8 & 548.1 & 13.2 & 548.9 & 57.1 & 548.0 & 8.8 & 99.8 \\
\hline 8304-79 & 118 & 51364 & 3.0 & $\begin{array}{r}16.998 \\
5\end{array}$ & 2.0 & 0.7264 & 2.2 & 0.0896 & 0.9 & 0.42 & 552.9 & 4.9 & 554.5 & 9.4 & 560.7 & 43.5 & 552.9 & 4.9 & 98.6 \\
\hline $8304-36$ & 145 & 33964 & 1.2 & $\begin{array}{r}17.221 \\
6 \\
\end{array}$ & 2.5 & 0.7171 & 2.6 & 0.0896 & 0.8 & 0.32 & 553.0 & 4.4 & 549.0 & 11.0 & 532.3 & 53.8 & 553.0 & 4.4 & 103.9 \\
\hline $8304-56$ & 483 & 4843 & 3.9 & $\begin{array}{r}16.050 \\
7 \\
\end{array}$ & 1.1 & 0.7695 & 2.8 & 0.0896 & 2.6 & 0.92 & 553.0 & 13.6 & 579.5 & 12.3 & 684.5 & 23.1 & 553.0 & 13.6 & 80.8 \\
\hline $8304-53$ & 301 & 45711 & 0.9 & $\begin{array}{r}17.072 \\
4 \\
\end{array}$ & 1.5 & 0.7257 & 2.6 & 0.0899 & 2.1 & 0.80 & 554.7 & 11.1 & 554.0 & 11.1 & 551.3 & 33.8 & 554.7 & 11.1 & 100.6 \\
\hline $8304-57$ & 75 & 6663 & 0.9 & $\begin{array}{r}16.721 \\
0 \\
\end{array}$ & 5.9 & 0.7412 & 6.0 & 0.0899 & 1.1 & 0.19 & 554.8 & 6.1 & 563.1 & 25.9 & 596.5 & 127.8 & 554.8 & 6.1 & 93.0 \\
\hline $8304-40$ & 140 & 33557 & 1.0 & $\begin{array}{r}17.035 \\
7\end{array}$ & 2.3 & 0.7289 & 2.6 & 0.0901 & 1.1 & 0.44 & 555.9 & 6.0 & 555.9 & 11.0 & 556.0 & 50.5 & 555.9 & 6.0 & 100.0 \\
\hline $8304-6$ & 400 & 3930 & 1.2 & $\begin{array}{r}16.215 \\
9\end{array}$ & 5.1 & 0.7660 & 6.7 & 0.0901 & 4.4 & 0.65 & 556.1 & 23.3 & 577.5 & 29.6 & 662.6 & 109.5 & 556.1 & 23.3 & 83.9 \\
\hline $8304-28$ & 105 & 1472 & 0.5 & $\begin{array}{r}14.888 \\
7 \\
\end{array}$ & $\begin{array}{r}12 . \\
2 \\
\end{array}$ & 0.8347 & $\begin{array}{r}12 . \\
7 \\
\end{array}$ & 0.0901 & 3.3 & 0.26 & 556.3 & 17.7 & 616.2 & 58.5 & 842.9 & 255.0 & 556.3 & 17.7 & 66.0 \\
\hline $8304-26$ & 453 & 32087 & 0.8 & $\begin{array}{r}16.963 \\
4 \\
\end{array}$ & 0.8 & 0.7333 & 1.2 & 0.0902 & 0.9 & 0.78 & 556.9 & 5.0 & 558.5 & 5.2 & 565.2 & 16.6 & 556.9 & 5.0 & 98.5 \\
\hline $8304-93$ & 125 & 32878 & 1.3 & $\begin{array}{r}17.023 \\
0\end{array}$ & 1.9 & 0.7355 & 2.9 & 0.0908 & 2.1 & 0.75 & 560.3 & 11.5 & 559.8 & 12.3 & 557.6 & 41.1 & 560.3 & 11.5 & 100.5 \\
\hline 8304-99 & 201 & 7543 & 1.8 & $\begin{array}{r}16.869 \\
1\end{array}$ & 2.8 & 0.7453 & 3.2 & 0.0912 & 1.6 & 0.48 & 562.5 & 8.4 & 565.5 & 14.0 & 577.4 & 61.6 & 562.5 & 8.4 & 97.4 \\
\hline $8304-41$ & 58 & 19297 & 1.1 & $\begin{array}{r}17.684 \\
1 \\
\end{array}$ & 3.7 & 0.7125 & 4.0 & 0.0914 & 1.3 & 0.32 & 563.7 & 6.9 & 546.2 & 16.7 & 473.9 & 82.8 & 563.7 & 6.9 & 118.9 \\
\hline $8304-86$ & 258 & 9378 & 1.2 & $\begin{array}{r}16.507 \\
3\end{array}$ & 3.7 & 0.7683 & 3.9 & 0.0920 & 1.3 & 0.32 & 567.2 & 6.8 & 578.8 & 17.3 & 624.3 & 80.0 & 567.2 & 6.8 & 90.9 \\
\hline $8304-18$ & 244 & 6636 & 1.6 & $\begin{array}{r}16.066 \\
7 \\
\end{array}$ & 2.1 & 0.7915 & 3.4 & 0.0922 & 2.6 & 0.78 & 568.7 & 14.4 & 592.0 & 15.1 & 682.4 & 44.6 & 568.7 & 14.4 & 83.3 \\
\hline 8304-82 & 496 & 45253 & 1.4 & $\begin{array}{r}17.108 \\
4 \\
\end{array}$ & 0.6 & 0.7455 & 1.8 & 0.0925 & 1.6 & 0.94 & 570.3 & 9.0 & 565.6 & 7.6 & 546.7 & 13.3 & 570.3 & 9.0 & 104.3 \\
\hline $8304-66$ & 133 & 39983 & 1.1 & $\begin{array}{r}16.671 \\
5 \\
\end{array}$ & 2.0 & 0.7658 & 2.9 & 0.0926 & 2.1 & 0.73 & 570.8 & 11.6 & 577.3 & 12.8 & 602.9 & 43.1 & 570.8 & 11.6 & 94.7 \\
\hline $8304-47$ & 37 & 19780 & 1.1 & $\begin{array}{r}16.444 \\
3\end{array}$ & 6.9 & 0.7828 & 7.1 & 0.0934 & 1.8 & 0.25 & 575.4 & 9.7 & 587.1 & 31.7 & 632.6 & 148.7 & 575.4 & 9.7 & 91.0 \\
\hline $8304-81$ & 88 & 34828 & 1.6 & $\begin{array}{r}16.890 \\
6\end{array}$ & 4.0 & 0.7732 & 4.3 & 0.0947 & 1.5 & 0.34 & 583.3 & 8.1 & 581.6 & 18.9 & 574.7 & 87.0 & 583.3 & 8.1 & 101.5 \\
\hline $8304-13$ & 70 & 5284 & 1.0 & $\begin{array}{r}16.503 \\
8\end{array}$ & 5.5 & 0.7953 & 6.0 & 0.0952 & 2.3 & 0.39 & 586.2 & 13.1 & 594.2 & 27.0 & 624.8 & 119.2 & 586.2 & 13.1 & 93.8 \\
\hline $8304-14$ & 221 & 71392 & 0.9 & $\begin{array}{r}16.645 \\
3\end{array}$ & 1.2 & 0.8071 & 1.8 & 0.0974 & 1.3 & 0.75 & 599.3 & 7.7 & 600.8 & 8.2 & 606.3 & 25.7 & 599.3 & 7.7 & 98.8 \\
\hline
\end{tabular}




\begin{tabular}{|c|c|c|c|c|c|c|c|c|c|c|c|c|c|c|c|c|c|c|c|}
\hline Analysis & $\mathrm{u}$ & $206 \mathrm{~Pb}$ & $\begin{array}{c}\mathrm{U} / \mathrm{T} \\
\mathrm{h}\end{array}$ & $206 \mathrm{~Pb}^{*}$ & \pm & $207 \mathrm{~Pb}^{*}$ & \pm & $\underset{*}{206 \mathrm{~Pb}}$ & \pm & $\begin{array}{c}\text { erro } \\
\mathrm{r}\end{array}$ & $\underset{*}{206 \mathrm{~Pb}}$ & \pm & $\underset{*}{207 \mathrm{~Pb}}$ & \pm & $\underset{*}{206 \mathrm{~Pb}}$ & \pm & $\begin{array}{l}\text { Best } \\
\text { age }\end{array}$ & \pm & Conc \\
\hline & $\begin{array}{c}(\mathrm{ppm} \\
)\end{array}$ & $204 \mathrm{~Pb}$ & & $207 \mathrm{~Pb}^{*}$ & $(\%)$ & $235 \mathrm{U}^{*}$ & $(\%)$ & $238 \mathrm{U}$ & (\%) & corr. & $238 \mathrm{U}^{*}$ & (Ma) & $235 \mathrm{U}$ & (Ma) & $\underset{*}{207 \mathrm{~Pb}}$ & (Ma) & (Ma) & (Ma) & $(\%)$ \\
\hline $8304-17$ & 110 & 37127 & 1.1 & $\begin{array}{r}16.569 \\
2 \\
\end{array}$ & 2.3 & 0.8168 & 3.1 & 0.0982 & 2.1 & 0.66 & 603.6 & 11.8 & 606.2 & 14.1 & 616.2 & 50.0 & 603.6 & 11.8 & 97.9 \\
\hline $8304-64$ & 38 & 10311 & 1.2 & $\begin{array}{r}16.421 \\
0 \\
\end{array}$ & 8.1 & 0.8260 & 8.2 & 0.0984 & 1.4 & 0.17 & 604.9 & 7.9 & 611.4 & 37.6 & 635.6 & 173.8 & 604.9 & 7.9 & 95.2 \\
\hline $8304-75$ & 127 & 26377 & 1.1 & $\begin{array}{r}16.748 \\
1 \\
\end{array}$ & 3.4 & 0.8104 & 3.6 & 0.0984 & 1.1 & 0.31 & 605.2 & 6.4 & 602.7 & 16.2 & 593.0 & 73.4 & 605.2 & 6.4 & 102.1 \\
\hline 8304-39 & 240 & 88078 & 0.8 & $\begin{array}{r}16.602 \\
9 \\
\end{array}$ & 0.8 & 0.8367 & 1.2 & 0.1008 & 0.9 & 0.72 & 618.8 & 5.0 & 617.3 & 5.5 & 611.8 & 17.7 & 618.8 & 5.0 & 101.1 \\
\hline $8304-58$ & 83 & 32904 & 1.6 & $\begin{array}{r}16.572 \\
5\end{array}$ & 3.4 & 0.8459 & 3.8 & 0.1017 & 1.6 & 0.41 & 624.2 & 9.2 & 622.4 & 17.5 & 615.8 & 74.1 & 624.2 & 9.2 & 101.4 \\
\hline $8304-100$ & 411 & 91611 & 1.5 & $\begin{array}{r}16.340 \\
0 \\
\end{array}$ & 0.9 & 0.8592 & 1.4 & 0.1018 & 1.1 & 0.79 & 625.1 & 6.6 & 629.7 & 6.6 & 646.3 & 18.4 & 625.1 & 6.6 & 96.7 \\
\hline $8304-80$ & 113 & 15462 & 0.3 & $\begin{array}{r}16.182 \\
4 \\
\end{array}$ & 5.2 & 0.8681 & 5.4 & 0.1019 & 1.4 & 0.26 & 625.5 & 8.4 & 634.6 & 25.5 & 667.0 & 111.9 & 625.5 & 8.4 & 93.8 \\
\hline $8304-65$ & 558 & 9712 & 4.8 & $\begin{array}{r}15.989 \\
7\end{array}$ & 1.9 & 0.8908 & 2.8 & 0.1033 & 2.0 & 0.72 & 633.7 & 12.0 & 646.8 & 13.3 & 692.6 & 41.2 & 633.7 & 12.0 & 91.5 \\
\hline 8304-15 & 241 & $\begin{array}{r}18407 \\
6 \\
\end{array}$ & 1.1 & $\begin{array}{r}16.576 \\
0 \\
\end{array}$ & 0.9 & 0.8655 & 4.0 & 0.1041 & 3.9 & 0.97 & 638.1 & 23.7 & 633.1 & 18.8 & 615.3 & 19.2 & 638.1 & 23.7 & 103.7 \\
\hline $8304-76$ & 151 & 55972 & 0.8 & $\begin{array}{r}16.548 \\
8 \\
\end{array}$ & 2.3 & 0.8705 & 2.8 & 0.1045 & 1.7 & 0.60 & 640.6 & 10.3 & 635.8 & 13.4 & 618.9 & 49.1 & 640.6 & 10.3 & 103.5 \\
\hline $8304-50$ & 233 & 29573 & 0.5 & $\begin{array}{r}16.127 \\
1 \\
\end{array}$ & 1.7 & 0.8952 & 2.0 & 0.1047 & 1.1 & 0.53 & 642.0 & 6.5 & 649.2 & 9.6 & 674.4 & 36.5 & 642.0 & 6.5 & 95.2 \\
\hline $8304-12$ & 89 & 9805 & 0.8 & $\begin{array}{r}15.888 \\
6 \\
\end{array}$ & 4.7 & 0.9146 & 4.7 & 0.1054 & 0.8 & 0.17 & 645.9 & 5.0 & 659.5 & 23.0 & 706.2 & 99.5 & 645.9 & 5.0 & 91.5 \\
\hline 8304-61 & 293 & 15650 & 2.9 & $\begin{array}{r}16.270 \\
2 \\
\end{array}$ & 1.1 & 0.8966 & 2.2 & 0.1058 & 1.9 & 0.87 & 648.3 & 11.9 & 649.9 & 10.7 & 655.5 & 23.8 & 648.3 & 11.9 & 98.9 \\
\hline $8304-44$ & 253 & 6531 & 0.8 & $\begin{array}{r}15.547 \\
7 \\
\end{array}$ & 2.7 & 1.0566 & 4.4 & 0.1191 & 3.4 & 0.78 & 725.6 & 23.4 & 732.1 & 22.7 & 752.1 & 57.4 & 725.6 & 23.4 & 96.5 \\
\hline 8304-71 & 152 & 66392 & 2.5 & $\begin{array}{r}15.114 \\
4 \\
\end{array}$ & 1.8 & 1.2292 & 2.7 & 0.1347 & 2.0 & 0.75 & 814.9 & 15.5 & 814.0 & 15.1 & 811.5 & 37.1 & 814.9 & 15.5 & 100.4 \\
\hline $8304-21$ & 45 & 16105 & 1.4 & $\begin{array}{r}14.487 \\
0 \\
\end{array}$ & 3.3 & 1.3847 & 3.7 & 0.1455 & 1.7 & 0.47 & 875.6 & 14.3 & 882.4 & 22.0 & 899.5 & 67.8 & 875.6 & 14.3 & 97.3 \\
\hline 8304-72 & 257 & 32516 & 1.2 & $\begin{array}{r}13.915 \\
6 \\
\end{array}$ & 0.9 & 1.6577 & 1.8 & 0.1673 & 1.5 & 0.85 & 997.2 & 13.8 & 992.5 & 11.1 & 982.1 & 18.6 & 982.1 & 18.6 & 101.5 \\
\hline 8304-97 & 294 & $\begin{array}{r}10469 \\
9 \\
\end{array}$ & 1.0 & $\begin{array}{r}13.906 \\
6 \\
\end{array}$ & 0.7 & 1.6730 & 1.8 & 0.1687 & 1.6 & 0.92 & 1005.1 & 15.1 & 998.3 & 11.2 & 983.4 & 14.1 & 983.4 & 14.1 & 102.2 \\
\hline 8304-3 & 254 & 41280 & 1.7 & $\begin{array}{r}13.880 \\
9 \\
\end{array}$ & 0.5 & 1.5154 & 1.4 & 0.1526 & 1.3 & 0.94 & 915.3 & 11.3 & 936.6 & 8.7 & 987.1 & 10.0 & 987.1 & 10.0 & 92.7 \\
\hline $8304-10$ & 220 & 11241 & 0.6 & $\begin{array}{r}13.709 \\
8 \\
\end{array}$ & 0.9 & 1.6473 & 1.3 & 0.1638 & 1.0 & 0.72 & 977.8 & 8.7 & 988.5 & 8.4 & 1012.3 & 18.7 & 1012.3 & 18.7 & 96.6 \\
\hline 8304-45 & 195 & 19219 & 1.6 & $\begin{array}{r}13.592 \\
2 \\
\end{array}$ & 0.9 & 1.4464 & 5.2 & 0.1426 & 5.2 & 0.99 & 859.3 & 41.5 & 908.4 & 31.4 & 1029.7 & 17.9 & 1029.7 & 17.9 & 83.4 \\
\hline 8304-43 & 90 & 92709 & 1.9 & $\begin{array}{r}13.453 \\
5 \\
\end{array}$ & 1.5 & 1.8579 & 1.9 & 0.1813 & 1.2 & 0.64 & 1074.0 & 12.0 & 1066.3 & 12.5 & 1050.5 & 29.4 & 1050.5 & 29.4 & 102.2 \\
\hline 8304-96 & 422 & $\begin{array}{r}24797 \\
1 \\
\end{array}$ & 2.2 & $\begin{array}{r}13.310 \\
6 \\
\end{array}$ & 0.4 & 1.9099 & 0.9 & 0.1844 & 0.8 & 0.91 & 1090.9 & 7.9 & 1084.6 & 5.8 & 1071.9 & 7.0 & 1071.9 & 7.0 & 101.8 \\
\hline $8304-85$ & 538 & $\begin{array}{r}10950 \\
7 \\
\end{array}$ & 3.4 & $\begin{array}{r}13.139 \\
3 \\
\end{array}$ & 0.4 & 1.8342 & 2.4 & 0.1748 & 2.4 & 0.99 & 1038.5 & 22.9 & 1057.8 & 15.9 & 1097.9 & 8.2 & 1097.9 & 8.2 & 94.6 \\
\hline 8304-24 & 166 & $\begin{array}{r}19556 \\
7 \\
\end{array}$ & 2.3 & $\begin{array}{r}12.883 \\
8 \\
\end{array}$ & 0.7 & 2.0356 & 1.0 & 0.1902 & 0.7 & 0.70 & 1122.5 & 7.5 & 1127.5 & 7.1 & 1137.1 & 14.8 & 1137.1 & 14.8 & 98.7 \\
\hline $8304-30$ & 190 & 57948 & 2.3 & $\begin{array}{r}12.562 \\
3 \\
\end{array}$ & 0.5 & 2.2581 & 1.6 & 0.2057 & 1.5 & 0.94 & 1206.0 & 16.5 & 1199.3 & 11.2 & 1187.2 & 10.4 & 1187.2 & 10.4 & 101.6 \\
\hline 8304-22 & 280 & 8833 & 0.5 & $\begin{array}{r}11.607 \\
1 \\
\end{array}$ & 0.6 & 2.3932 & 5.6 & 0.2015 & 5.6 & 0.99 & 1183.2 & 60.3 & 1240.6 & 40.2 & 1341.6 & 12.0 & 1341.6 & 12.0 & 88.2 \\
\hline $8304-83$ & 142 & $\begin{array}{r}34195 \\
3 \\
\end{array}$ & 2.2 & $\begin{array}{r}11.513 \\
6 \\
\end{array}$ & 0.4 & 2.8257 & 1.9 & 0.2360 & 1.9 & 0.98 & 1365.7 & 23.3 & 1362.4 & 14.5 & 1357.2 & 8.1 & 1357.2 & 8.1 & 100.6 \\
\hline $8304-32$ & 62 & 87470 & 5.7 & $\begin{array}{r}11.304 \\
7\end{array}$ & 1.8 & 2.9808 & 2.3 & 0.2444 & 1.4 & 0.60 & 1409.5 & 17.3 & 1402.7 & 17.3 & 1392.5 & 34.8 & 1392.5 & 34.8 & 101.2 \\
\hline 8304-69 & 77 & 56384 & 1.2 & $\begin{array}{r}10.328 \\
0 \\
\end{array}$ & 1.2 & 3.6122 & 1.5 & 0.2706 & 0.8 & 0.58 & 1543.7 & 11.5 & 1552.2 & 11.6 & 1563.8 & 22.3 & 1563.8 & 22.3 & 98.7 \\
\hline 8304-5 & 199 & 99719 & 1.5 & 9.1561 & 0.3 & 4.7531 & 1.8 & 0.3156 & 1.8 & 0.99 & 1768.4 & 27.8 & 1776.7 & 15.3 & 1786.4 & 5.2 & 1786.4 & 5.2 & 99.0 \\
\hline 8304-4 & 186 & 14176 & 0.9 & 9.0609 & 2.1 & 5.1315 & 2.5 & 0.3372 & 1.4 & 0.55 & 1873.3 & 23.0 & 1841.3 & 21.6 & 1805.4 & 38.5 & 1805.4 & 38.5 & 103.8 \\
\hline 8304-90 & 109 & 65518 & 0.7 & 8.9874 & 0.8 & 4.8467 & 1.2 & 0.3159 & 0.9 & 0.75 & 1769.8 & 14.2 & 1793.0 & 10.3 & 1820.2 & 14.8 & 1820.2 & 14.8 & 97.2 \\
\hline 8304-35 & 168 & 15211 & 1.0 & 8.7752 & 0.7 & 4.5026 & 9.0 & 0.2866 & 9.0 & 1.00 & 1624.3 & $\begin{array}{r}128 . \\
8 \\
\end{array}$ & 1731.5 & 74.9 & 1863.5 & 12.5 & 1863.5 & 12.5 & 87.2 \\
\hline $8304-70$ & 103 & $\begin{array}{r}12847 \\
1 \\
\end{array}$ & 0.7 & 8.7412 & 0.5 & 5.3237 & 1.2 & 0.3375 & 1.1 & 0.89 & 1874.7 & 17.5 & 1872.7 & 10.3 & 1870.5 & 9.8 & 1870.5 & 9.8 & 100.2 \\
\hline $8304-91$ & 164 & $\begin{array}{r}24419 \\
0 \\
\end{array}$ & 1.9 & 8.6426 & 0.3 & 5.5626 & 1.7 & 0.3487 & 1.7 & 0.99 & 1928.3 & 28.6 & 1910.3 & 15.0 & 1890.9 & 5.0 & 1890.9 & 5.0 & 102.0 \\
\hline 8304-51 & 182 & 24439 & 0.8 & 8.6399 & 0.5 & 4.7814 & 3.5 & 0.2996 & 3.5 & 0.99 & 1689.4 & 51.9 & 1781.6 & 29.7 & 1891.4 & 9.0 & 1891.4 & 9.0 & 89.3 \\
\hline $8304-74$ & 73 & 71164 & 1.0 & 8.5063 & 1.5 & 5.0313 & 3.7 & 0.3104 & 3.4 & 0.91 & 1742.7 & 52.1 & 1824.6 & 31.7 & 1919.4 & 27.7 & 1919.4 & 27.7 & 90.8 \\
\hline $8304-68$ & 44 & 46834 & 0.9 & 8.2591 & 1.1 & 5.8940 & 1.3 & 0.3531 & 0.7 & 0.56 & 1949.2 & 12.4 & 1960.3 & 11.5 & 1972.2 & 19.6 & 1972.2 & 19.6 & 98.8 \\
\hline
\end{tabular}




\begin{tabular}{|c|c|c|c|c|c|c|c|c|c|c|c|c|c|c|c|c|c|c|c|}
\hline Analysis & U & $206 \mathrm{~Pb}$ & $\begin{array}{c}\mathrm{U} / \mathrm{T} \\
\mathrm{h}\end{array}$ & $206 \mathrm{~Pb}^{*}$ & \pm & $207 \mathrm{~Pb}^{*}$ & \pm & $\underset{*}{206 \mathrm{~Pb}}$ & \pm & $\begin{array}{c}\text { erro } \\
\mathrm{r}\end{array}$ & $\underset{*}{206 \mathrm{~Pb}}$ & \pm & $\underset{*}{207 \mathrm{~Pb}}$ & \pm & $\underset{*}{206 \mathrm{~Pb}}$ & \pm & $\begin{array}{l}\text { Best } \\
\text { age }\end{array}$ & \pm & Conc \\
\hline & $\begin{array}{c}(\mathrm{ppm} \\
)\end{array}$ & $204 \mathrm{~Pb}$ & & $207 \mathrm{~Pb}^{*}$ & (\%) & $235 \mathrm{U}^{*}$ & (\%) & $238 \mathrm{U}$ & (\%) & corr. & $238 \mathrm{U}^{*}$ & (Ma) & $235 \mathrm{U}$ & (Ma) & $\underset{*}{207 \mathrm{~Pb}}$ & (Ma) & (Ma) & (Ma) & (\%) \\
\hline $8304-87$ & 128 & 26770 & 0.8 & 8.1886 & 0.5 & 6.1396 & 2.6 & 0.3646 & 2.5 & 0.98 & 2004.1 & 43.6 & 1995.9 & 22.6 & 1987.4 & 9.3 & 1987.4 & 9.3 & 100.8 \\
\hline 8304-2 & 82 & $\begin{array}{r}19359 \\
3 \\
\end{array}$ & 0.8 & 8.1726 & 0.4 & 6.0924 & 1.4 & 0.3611 & 1.3 & 0.96 & 1987.5 & 22.6 & 1989.2 & 12.0 & 1990.9 & 6.9 & 1990.9 & 6.9 & 99.8 \\
\hline $8304-54$ & 187 & $\begin{array}{r}13103 \\
8 \\
\end{array}$ & 2.1 & 8.0247 & 0.3 & 6.2946 & 1.3 & 0.3663 & 1.3 & 0.97 & 2012.2 & 21.7 & 2017.7 & 11.3 & 2023.3 & 5.7 & 2023.3 & 5.7 & 99.4 \\
\hline 8304-19 & 63 & 69422 & 0.6 & 7.8335 & 0.9 & 5.9304 & 2.8 & 0.3369 & 2.7 & 0.95 & 1871.9 & 43.2 & 1965.7 & 24.3 & 2065.9 & 15.0 & 2065.9 & 15.0 & 90.6 \\
\hline $8304-16$ & 246 & 22079 & 5.1 & 7.8266 & 0.7 & 6.4111 & 4.1 & 0.3639 & 4.1 & 0.98 & 2000.7 & 69.8 & 2033.8 & 36.2 & 2067.5 & 12.7 & 2067.5 & 12.7 & 96.8 \\
\hline $8304-20$ & 117 & $\begin{array}{r}37067 \\
8 \\
\end{array}$ & 1.0 & 7.7164 & 0.3 & 6.9925 & 1.1 & 0.3913 & 1.0 & 0.96 & 2129.0 & 18.5 & 2110.5 & 9.5 & 2092.4 & 5.5 & 2092.4 & 5.5 & 101.7 \\
\hline $8304-1$ & 257 & $\begin{array}{r}38971 \\
2 \\
\end{array}$ & 2.9 & 7.6988 & 0.2 & 6.7451 & 1.5 & 0.3766 & 1.5 & 0.99 & 2060.5 & 26.6 & 2078.6 & 13.4 & 2096.5 & 3.3 & 2096.5 & 3.3 & 98.3 \\
\hline 8304-31 & 127 & $\begin{array}{r}23752 \\
0 \\
\end{array}$ & 2.1 & 7.6168 & 0.6 & 6.7576 & 1.3 & 0.3733 & 1.1 & 0.90 & 2044.9 & 19.8 & 2080.2 & 11.1 & 2115.3 & 9.7 & 2115.3 & 9.7 & 96.7 \\
\hline $8304-8$ & 301 & 20379 & 0.7 & 7.5909 & 0.1 & 5.6216 & 2.4 & 0.3095 & 2.3 & 1.00 & 1738.2 & 35.8 & 1919.4 & 20.3 & 2121.2 & 2.3 & 2121.2 & 2.3 & 81.9 \\
\hline $8304-98$ & 207 & 50587 & 1.2 & 7.5816 & 0.4 & 6.6654 & 1.3 & 0.3665 & 1.2 & 0.96 & 2013.0 & 21.4 & 2068.0 & 11.4 & 2123.4 & 6.1 & 2123.4 & 6.1 & 94.8 \\
\hline 8304-29 & 358 & $\begin{array}{r}49378 \\
1 \\
\end{array}$ & 2.0 & 7.4244 & 0.1 & 7.4293 & 1.5 & 0.4000 & 1.5 & 1.00 & 2169.2 & 27.9 & 2164.5 & 13.6 & 2160.0 & 1.4 & 2160.0 & 1.4 & 100.4 \\
\hline 8304-33 & 144 & $\begin{array}{r}16279 \\
0\end{array}$ & 1.6 & 7.3015 & 0.2 & 7.2097 & 1.2 & 0.3818 & 1.2 & 0.98 & 2084.7 & 21.5 & 2137.7 & 10.9 & 2189.1 & 3.8 & 2189.1 & 3.8 & 95.2 \\
\hline $8304-9$ & 125 & 28341 & 1.3 & 7.2093 & 0.3 & 7.6980 & 1.9 & 0.4025 & 1.9 & 0.98 & 2180.6 & 34.7 & 2196.4 & 17.1 & 2211.1 & 5.9 & 2211.1 & 5.9 & 98.6 \\
\hline 8304-63 & 317 & $\begin{array}{r}47596 \\
6 \\
\end{array}$ & 1.1 & 7.1788 & 0.1 & 7.8980 & 1.1 & 0.4112 & 1.1 & 0.99 & 2220.5 & 20.2 & 2219.4 & 9.8 & 2218.5 & 2.4 & 2218.5 & 2.4 & 100.1 \\
\hline $8304-23$ & 102 & 25082 & 0.6 & 6.7388 & 0.4 & 9.2770 & 1.9 & 0.4534 & 1.8 & 0.98 & 2410.4 & 36.5 & 2365.7 & 17.0 & 2327.5 & 7.0 & 2327.5 & 7.0 & 103.6 \\
\hline $8304-42$ & 86 & $\begin{array}{r}14191 \\
0 \\
\end{array}$ & 1.1 & 5.7159 & 0.6 & $\begin{array}{r}12.125 \\
9 \\
\end{array}$ & 1.5 & 0.5027 & 1.4 & 0.92 & 2625.3 & 30.4 & 2614.2 & 14.3 & 2605.5 & 9.8 & 2605.5 & 9.8 & 100.8 \\
\hline
\end{tabular}

\begin{tabular}{|c|c|c|c|c|c|c|c|c|c|c|c|c|c|c|c|c|c|c|c|}
\hline Analysis & U & $206 \mathrm{~Pb}$ & $\begin{array}{c}\mathrm{U} / \mathrm{T} \\
\mathrm{h} \\
\end{array}$ & $206 \mathrm{~Pb}^{*}$ & \pm & $207 \mathrm{~Pb}^{*}$ & \pm & $\underset{*}{206 \mathrm{~Pb}}$ & \pm & $\begin{array}{c}\text { erro } \\
\mathrm{r}\end{array}$ & $\underset{*}{206 \mathrm{~Pb}}$ & \pm & $\underset{*}{207 \mathrm{~Pb}}$ & \pm & $\underset{*}{206 \mathrm{~Pb}}$ & \pm & $\begin{array}{l}\text { Best } \\
\text { age }\end{array}$ & \pm & Conc \\
\hline & $\begin{array}{c}(\mathrm{ppm} \\
)\end{array}$ & $204 \mathrm{~Pb}$ & & $207 \mathrm{~Pb}^{*}$ & $(\%)$ & $235 \mathrm{U}^{*}$ & $(\%)$ & $238 \mathrm{U}$ & $(\%)$ & corr. & $238 \mathrm{U}^{*}$ & (Ma) & $235 \mathrm{U}$ & (Ma) & $\underset{*}{207 \mathrm{~Pb}}$ & (Ma) & (Ma) & (Ma) & (\%) \\
\hline $8305-67$ & 181 & 27826 & 0.8 & $\begin{array}{r}16.954 \\
3 \\
\end{array}$ & 2.0 & 0.7114 & 2.6 & 0.0875 & 1.7 & 0.65 & 540.6 & 8.6 & 545.6 & 10.9 & 566.5 & 42.9 & 540.6 & 8.6 & 95.4 \\
\hline $8305-26$ & 44 & 28063 & 0.5 & $\begin{array}{r}17.796 \\
6 \\
\end{array}$ & 6.5 & 0.6781 & 6.7 & 0.0875 & 1.3 & 0.19 & 540.9 & 6.6 & 525.6 & 27.4 & 459.9 & 145.3 & 540.9 & 6.6 & 117.6 \\
\hline $8305-50$ & 32 & 11588 & 0.9 & $\begin{array}{r}17.377 \\
3 \\
\end{array}$ & 8.8 & 0.6960 & 9.1 & 0.0877 & 2.4 & 0.27 & 542.1 & 12.7 & 536.4 & 38.1 & 512.5 & 193.9 & 542.1 & 12.7 & 105.8 \\
\hline $8305-15$ & 294 & $\begin{array}{r}11264 \\
4 \\
\end{array}$ & 0.8 & $\begin{array}{r}17.251 \\
3 \\
\end{array}$ & 1.1 & 0.7016 & 1.4 & 0.0878 & 0.9 & 0.64 & 542.4 & 4.6 & 539.7 & 5.8 & 528.5 & 23.3 & 542.4 & 4.6 & 102.6 \\
\hline 8305-69 & 146 & 68347 & 1.1 & $\begin{array}{r}17.251 \\
0 \\
\end{array}$ & 4.0 & 0.7082 & 4.1 & 0.0886 & 1.1 & 0.26 & 547.3 & 5.7 & 543.7 & 17.4 & 528.6 & 87.6 & 547.3 & 5.7 & 103.6 \\
\hline $8305-90$ & 216 & $\begin{array}{r}10559 \\
4 \\
\end{array}$ & 2.0 & $\begin{array}{r}17.019 \\
3 \\
\end{array}$ & 1.7 & 0.7189 & 2.0 & 0.0887 & 1.0 & 0.49 & 548.1 & 5.1 & 550.0 & 8.3 & 558.1 & 37.2 & 548.1 & 5.1 & 98.2 \\
\hline 8305-98 & 91 & 16136 & 1.9 & $\begin{array}{r}17.148 \\
0\end{array}$ & 3.5 & 0.7156 & 4.1 & 0.0890 & 2.1 & 0.51 & 549.6 & 11.1 & 548.0 & 17.4 & 541.7 & 77.1 & 549.6 & 11.1 & 101.5 \\
\hline $8305-89$ & 198 & $\begin{array}{r}12659 \\
4 \\
\end{array}$ & 0.9 & $\begin{array}{r}17.204 \\
1 \\
\end{array}$ & 2.2 & 0.7137 & 2.3 & 0.0891 & 0.9 & 0.37 & 549.9 & 4.6 & 546.9 & 9.9 & 534.5 & 47.4 & 549.9 & 4.6 & 102.9 \\
\hline $8305-57$ & 177 & 80536 & 11.9 & $\begin{array}{r}17.003 \\
4 \\
\end{array}$ & 2.0 & 0.7222 & 2.7 & 0.0891 & 1.8 & 0.66 & 550.0 & 9.3 & 552.0 & 11.4 & 560.1 & 43.4 & 550.0 & 9.3 & 98.2 \\
\hline $8305-83$ & 190 & 6198 & 0.7 & $\begin{array}{r}15.846 \\
2 \\
\end{array}$ & 7.4 & 0.7753 & 7.5 & 0.0891 & 1.6 & 0.21 & 550.2 & 8.2 & 582.8 & 33.5 & 711.8 & 157.1 & 550.2 & 8.2 & 77.3 \\
\hline $8305-48$ & 177 & 13079 & 1.5 & $\begin{array}{r}16.980 \\
2 \\
\end{array}$ & 1.4 & 0.7253 & 2.0 & 0.0893 & 1.4 & 0.69 & 551.5 & 7.2 & 553.8 & 8.5 & 563.1 & 31.5 & 551.5 & 7.2 & 97.9 \\
\hline $8305-3$ & 66 & 20022 & 1.1 & $\begin{array}{r}17.816 \\
3 \\
\end{array}$ & 5.3 & 0.6941 & 5.8 & 0.0897 & 2.2 & 0.38 & 553.7 & 11.8 & 535.3 & 24.1 & 457.5 & 118.7 & 553.7 & 11.8 & 121.0 \\
\hline $8305-47$ & 265 & 61600 & 0.8 & $\begin{array}{r}17.201 \\
9 \\
\end{array}$ & 0.8 & 0.7192 & 1.4 & 0.0897 & 1.2 & 0.82 & 553.9 & 6.2 & 550.2 & 6.0 & 534.8 & 17.6 & 553.9 & 6.2 & 103.6 \\
\hline $8305-91$ & 72 & 29342 & 3.1 & $\begin{array}{r}17.537 \\
9 \\
\end{array}$ & 7.3 & 0.7064 & 7.4 & 0.0899 & 1.2 & 0.17 & 554.7 & 6.5 & 542.6 & 31.2 & 492.3 & 161.4 & 554.7 & 6.5 & 112.7 \\
\hline $8305-49$ & 57 & 22339 & 0.9 & $\begin{array}{r}17.013 \\
5 \\
\end{array}$ & 7.8 & 0.7294 & 7.9 & 0.0900 & 1.5 & 0.19 & 555.5 & 7.8 & 556.2 & 34.0 & 558.8 & 170.2 & 555.5 & 7.8 & 99.4 \\
\hline $8305-63$ & 345 & 44904 & 0.9 & $\begin{array}{r}16.961 \\
0 \\
\end{array}$ & 1.0 & 0.7339 & 2.3 & 0.0903 & 2.1 & 0.90 & 557.2 & 11.0 & 558.8 & 9.8 & 565.6 & 21.5 & 557.2 & 11.0 & 98.5 \\
\hline $8305-97$ & 410 & 25903 & 0.9 & $\begin{array}{r}17.043 \\
6 \\
\end{array}$ & 1.1 & 0.7327 & 2.5 & 0.0906 & 2.2 & 0.90 & 558.9 & 11.9 & 558.1 & 10.6 & 555.0 & 23.9 & 558.9 & 11.9 & 100.7 \\
\hline $8305-58$ & 58 & 15053 & 1.2 & $\begin{array}{r}16.492 \\
9 \\
\end{array}$ & 5.3 & 0.7572 & 5.4 & 0.0906 & 1.2 & 0.23 & 558.9 & 6.7 & 572.4 & 23.7 & 626.2 & 113.8 & 558.9 & 6.7 & 89.3 \\
\hline $8305-43$ & 274 & 12055 & 1.3 & $\begin{array}{r}16.705 \\
9 \\
\end{array}$ & 4.2 & 0.7492 & 5.2 & 0.0908 & 3.1 & 0.59 & 560.1 & 16.4 & 567.8 & 22.6 & 598.5 & 91.2 & 560.1 & 16.4 & 93.6 \\
\hline $8305-8$ & 100 & 5817 & 2.5 & $\begin{array}{r}15.773 \\
9\end{array}$ & 5.8 & 0.7941 & 6.0 & 0.0908 & 1.4 & 0.24 & 560.6 & 7.8 & 593.5 & 27.0 & 721.5 & 123.8 & 560.6 & 7.8 & 77.7 \\
\hline
\end{tabular}




\begin{tabular}{|c|c|c|c|c|c|c|c|c|c|c|c|c|c|c|c|c|c|c|c|}
\hline Analysis & U & $206 \mathrm{~Pb}$ & $\begin{array}{c}\mathrm{U} / \mathrm{T} \\
\mathrm{h}\end{array}$ & $206 \mathrm{~Pb}^{\star}$ & \pm & $207 \mathrm{~Pb}^{*}$ & \pm & $\underset{*}{206 \mathrm{~Pb}}$ & \pm & $\begin{array}{c}\text { erro } \\
\mathrm{r}\end{array}$ & $\underset{*}{206 \mathrm{~Pb}}$ & \pm & $\underset{*}{207 \mathrm{~Pb}}$ & \pm & $\underset{*}{206 \mathrm{~Pb}}$ & \pm & $\begin{array}{c}\text { Best } \\
\text { age }\end{array}$ & \pm & Conc \\
\hline & $\begin{array}{c}\text { (ppm } \\
\text { ) }\end{array}$ & $204 \mathrm{~Pb}$ & & $207 \mathrm{~Pb}^{*}$ & $(\%)$ & $235 \mathrm{U}^{*}$ & $(\%)$ & $238 \mathrm{U}$ & (\%) & corr. & $238 \mathrm{U}^{*}$ & (Ma) & $235 \mathrm{U}$ & (Ma) & $\underset{*}{207 \mathrm{~Pb}}$ & (Ma) & (Ma) & (Ma) & $(\%)$ \\
\hline $8305-30$ & 92 & 38111 & 1.0 & $\begin{array}{r}16.379 \\
8 \\
\end{array}$ & 2.7 & 0.7660 & 3.4 & 0.0910 & 2.1 & 0.60 & 561.5 & 11.1 & 577.5 & 15.0 & 641.1 & 58.5 & 561.5 & 11.1 & 87.6 \\
\hline $8305-37$ & 96 & 68453 & 0.8 & $\begin{array}{r}17.301 \\
4 \\
\end{array}$ & 3.2 & 0.7279 & 3.5 & 0.0913 & 1.6 & 0.45 & 563.5 & 8.6 & 555.3 & 15.1 & 522.1 & 69.5 & 563.5 & 8.6 & 107.9 \\
\hline $8305-94$ & 33 & 18813 & 1.7 & $\begin{array}{r}17.763 \\
5 \\
\end{array}$ & $\begin{array}{r}13 . \\
6 \\
\end{array}$ & 0.7105 & $\begin{array}{r}13 . \\
8 \\
\end{array}$ & 0.0915 & 2.6 & 0.19 & 564.6 & 13.8 & 545.0 & 58.4 & 464.0 & 302.4 & 564.6 & 13.8 & 121.7 \\
\hline $8305-56$ & 120 & 30261 & 1.2 & $\begin{array}{r}17.114 \\
7\end{array}$ & 3.6 & 0.7417 & 4.4 & 0.0921 & 2.4 & 0.56 & 567.7 & 13.2 & 563.4 & 18.9 & 545.9 & 79.2 & 567.7 & 13.2 & 104.0 \\
\hline $8305-61$ & 35 & 15198 & 0.7 & $\begin{array}{r}16.528 \\
5 \\
\end{array}$ & $\begin{array}{r}11 . \\
8 \\
\end{array}$ & 0.7737 & $\begin{array}{r}11 . \\
9 \\
\end{array}$ & 0.0927 & 1.3 & 0.11 & 571.8 & 7.3 & 581.9 & 52.5 & 621.5 & 254.8 & 571.8 & 7.3 & 92.0 \\
\hline $8305-4$ & 48 & 20766 & 1.1 & $\begin{array}{r}17.500 \\
9 \\
\end{array}$ & 4.5 & 0.7376 & 5.6 & 0.0936 & 3.2 & 0.58 & 576.9 & 17.9 & 561.0 & 24.1 & 496.9 & 100.1 & 576.9 & 17.9 & 116.1 \\
\hline 8305-99 & 137 & 13628 & 3.1 & $\begin{array}{r}16.178 \\
7 \\
\end{array}$ & 5.5 & 0.8318 & 5.8 & 0.0976 & 1.9 & 0.34 & 600.3 & 11.2 & 614.6 & 26.7 & 667.5 & 116.9 & 600.3 & 11.2 & 89.9 \\
\hline $8305-28$ & 73 & 31985 & 1.0 & $\begin{array}{r}16.800 \\
2 \\
\end{array}$ & 3.4 & 0.8188 & 3.6 & 0.0998 & 1.0 & 0.28 & 613.0 & 6.0 & 607.4 & 16.4 & 586.3 & 74.6 & 613.0 & 6.0 & 104.6 \\
\hline $8305-86$ & 100 & 18367 & 1.8 & $\begin{array}{r}16.335 \\
2 \\
\end{array}$ & 3.6 & 0.8499 & 3.8 & 0.1007 & 1.1 & 0.28 & 618.5 & 6.3 & 624.6 & 17.6 & 646.9 & 77.7 & 618.5 & 6.3 & 95.6 \\
\hline 8305-35 & 94 & 25907 & 3.8 & $\begin{array}{r}16.597 \\
7 \\
\end{array}$ & 3.3 & 0.8429 & 3.6 & 0.1015 & 1.2 & 0.34 & 623.0 & 7.3 & 620.7 & 16.5 & 612.5 & 72.3 & 623.0 & 7.3 & 101.7 \\
\hline $8305-88$ & 104 & 14882 & 0.8 & $\begin{array}{r}16.385 \\
0 \\
\end{array}$ & 1.7 & 0.8612 & 1.8 & 0.1023 & 0.7 & 0.38 & 628.1 & 4.1 & 630.8 & 8.6 & 640.4 & 36.3 & 628.1 & 4.1 & 98.1 \\
\hline $8305-14$ & 199 & 76314 & 0.7 & $\begin{array}{r}16.469 \\
0 \\
\end{array}$ & 1.3 & 0.8575 & 1.7 & 0.1024 & 1.0 & 0.62 & 628.6 & 6.3 & 628.8 & 7.9 & 629.3 & 28.6 & 628.6 & 6.3 & 99.9 \\
\hline $8305-41$ & 447 & $\begin{array}{r}12773 \\
8 \\
\end{array}$ & 2.0 & $\begin{array}{r}16.440 \\
4 \\
\end{array}$ & 0.6 & 0.8723 & 1.1 & 0.1040 & 0.9 & 0.84 & 637.9 & 5.8 & 636.8 & 5.4 & 633.1 & 13.3 & 637.9 & 5.8 & 100.7 \\
\hline $8305-82$ & 107 & 46435 & 0.9 & $\begin{array}{r}16.570 \\
2 \\
\end{array}$ & 3.3 & 0.8663 & 4.0 & 0.1041 & 2.2 & 0.56 & 638.5 & 13.6 & 633.6 & 18.6 & 616.1 & 70.5 & 638.5 & 13.6 & 103.6 \\
\hline $8305-46$ & 77 & 5367 & 0.5 & $\begin{array}{r}15.837 \\
3 \\
\end{array}$ & 4.9 & 0.9070 & 5.1 & 0.1042 & 1.5 & 0.30 & 638.9 & 9.4 & 655.5 & 24.8 & 713.0 & 104.1 & 638.9 & 9.4 & 89.6 \\
\hline 8305-77 & 54 & 23058 & 0.7 & $\begin{array}{r}16.522 \\
4 \\
\end{array}$ & 7.6 & 0.8887 & 7.9 & 0.1065 & 2.1 & 0.26 & 652.3 & 12.9 & 645.6 & 37.6 & 622.3 & 164.0 & 652.3 & 12.9 & 104.8 \\
\hline $8305-11$ & 103 & 33381 & 0.6 & $\begin{array}{r}16.332 \\
1 \\
\end{array}$ & 2.1 & 0.9017 & 2.2 & 0.1068 & 0.7 & 0.33 & 654.1 & 4.6 & 652.6 & 10.8 & 647.3 & 45.6 & 654.1 & 4.6 & 101.1 \\
\hline 8305-95 & 158 & 66923 & 2.7 & $\begin{array}{r}16.298 \\
5 \\
\end{array}$ & 1.7 & 0.9097 & 2.1 & 0.1075 & 1.3 & 0.59 & 658.4 & 8.0 & 656.9 & 10.4 & 651.7 & 37.2 & 658.4 & 8.0 & 101.0 \\
\hline $8305-13$ & 177 & $\begin{array}{r}10023 \\
8 \\
\end{array}$ & 1.4 & $\begin{array}{r}16.123 \\
4 \\
\end{array}$ & 1.8 & 0.9256 & 2.8 & 0.1082 & 2.1 & 0.76 & 662.5 & 13.2 & 665.3 & 13.5 & 674.8 & 38.5 & 662.5 & 13.2 & 98.2 \\
\hline $8305-9$ & 112 & 37161 & 1.4 & $\begin{array}{r}16.132 \\
1 \\
\end{array}$ & 1.5 & 0.9306 & 1.7 & 0.1089 & 0.9 & 0.51 & 666.2 & 5.6 & 667.9 & 8.5 & 673.7 & 31.9 & 666.2 & 5.6 & 98.9 \\
\hline $8305-22$ & 206 & 53693 & 1.6 & $\begin{array}{r}16.057 \\
8 \\
\end{array}$ & 0.8 & 0.9524 & 1.3 & 0.1109 & 1.1 & 0.83 & 678.1 & 7.2 & 679.4 & 6.7 & 683.6 & 16.0 & 678.1 & 7.2 & 99.2 \\
\hline 8305-38 & 450 & 53263 & 2.8 & $\begin{array}{r}15.234 \\
6 \\
\end{array}$ & 0.4 & 1.1987 & 1.2 & 0.1324 & 1.1 & 0.93 & 801.8 & 8.1 & 800.0 & 6.4 & 794.9 & 9.1 & 801.8 & 8.1 & 100.9 \\
\hline $8305-64$ & 46 & 24027 & 0.7 & $\begin{array}{r}14.552 \\
8 \\
\end{array}$ & 4.1 & 1.4457 & 4.2 & 0.1526 & 1.0 & 0.24 & 915.4 & 8.5 & 908.1 & 25.1 & 890.2 & 83.9 & 890.2 & 83.9 & 102.8 \\
\hline $8305-100$ & 91 & 23775 & 2.0 & $\begin{array}{r}13.936 \\
6 \\
\end{array}$ & 2.0 & 1.6732 & 2.2 & 0.1691 & 0.8 & 0.35 & 1007.3 & 7.0 & 998.4 & 13.8 & 978.9 & 41.5 & 978.9 & 41.5 & 102.9 \\
\hline 8305-78 & 220 & 60408 & 1.0 & $\begin{array}{r}13.923 \\
5 \\
\end{array}$ & 1.1 & 1.6025 & 2.0 & 0.1618 & 1.7 & 0.84 & 966.9 & 15.5 & 971.2 & 12.8 & 980.9 & 22.3 & 980.9 & 22.3 & 98.6 \\
\hline $8305-12$ & 427 & 24120 & 0.9 & $\begin{array}{r}13.680 \\
2 \\
\end{array}$ & 0.5 & 1.6914 & 1.4 & 0.1678 & 1.3 & 0.92 & 1000.1 & 11.7 & 1005.3 & 8.8 & 1016.7 & 11.0 & 1016.7 & 11.0 & 98.4 \\
\hline $8305-25$ & 108 & 72553 & 1.3 & $\begin{array}{r}13.556 \\
7\end{array}$ & 1.9 & 1.8265 & 2.1 & 0.1796 & 0.9 & 0.44 & 1064.7 & 8.8 & 1055.0 & 13.5 & 1035.0 & 37.5 & 1035.0 & 37.5 & 102.9 \\
\hline $8305-93$ & 175 & 61509 & 5.4 & $\begin{array}{r}13.555 \\
3 \\
\end{array}$ & 0.6 & 1.6752 & 1.1 & 0.1647 & 0.9 & 0.82 & 982.8 & 8.3 & 999.2 & 7.0 & 1035.2 & 12.7 & 1035.2 & 12.7 & 94.9 \\
\hline 8305-73 & 142 & 41108 & 2.1 & $\begin{array}{r}13.489 \\
5 \\
\end{array}$ & 1.3 & 1.8268 & 4.8 & 0.1787 & 4.6 & 0.96 & 1060.0 & 44.9 & 1055.1 & 31.3 & 1045.1 & 26.0 & 1045.1 & 26.0 & 101.4 \\
\hline $8305-51$ & 106 & 69800 & 1.2 & $\begin{array}{r}13.112 \\
4 \\
\end{array}$ & 1.2 & 1.9614 & 1.7 & 0.1865 & 1.1 & 0.67 & 1102.6 & 11.3 & 1102.4 & 11.2 & 1102.0 & 24.5 & 1102.0 & 24.5 & 100.0 \\
\hline $8305-27$ & 185 & $\begin{array}{r}17532 \\
6 \\
\end{array}$ & 1.6 & $\begin{array}{r}12.921 \\
4 \\
\end{array}$ & 1.7 & 2.0149 & 3.0 & 0.1888 & 2.5 & 0.83 & 1115.0 & 25.1 & 1120.6 & 20.1 & 1131.3 & 33.1 & 1131.3 & 33.1 & 98.6 \\
\hline $8305-80$ & 72 & 24781 & 1.5 & $\begin{array}{r}12.860 \\
2 \\
\end{array}$ & 1.9 & 2.0331 & 3.4 & 0.1896 & 2.8 & 0.84 & 1119.4 & 29.1 & 1126.7 & 23.1 & 1140.7 & 37.0 & 1140.7 & 37.0 & 98.1 \\
\hline 8305-16 & 74 & 35833 & 2.0 & $\begin{array}{r}12.769 \\
8 \\
\end{array}$ & 2.0 & 2.1444 & 2.8 & 0.1986 & 2.0 & 0.72 & 1167.8 & 21.4 & 1163.2 & 19.3 & 1154.7 & 38.7 & 1154.7 & 38.7 & 101.1 \\
\hline $8305-2$ & 111 & 89754 & 2.2 & $\begin{array}{r}12.487 \\
9 \\
\end{array}$ & 1.5 & 2.2819 & 2.9 & 0.2067 & 2.5 & 0.85 & 1211.1 & 27.5 & 1206.7 & 20.7 & 1198.9 & 30.4 & 1198.9 & 30.4 & 101.0 \\
\hline 8305-85 & 143 & 70918 & 2.3 & $\begin{array}{r}12.430 \\
5 \\
\end{array}$ & 1.0 & 2.4058 & 4.1 & 0.2169 & 4.0 & 0.97 & 1265.4 & 45.9 & 1244.3 & 29.6 & 1208.0 & 20.4 & 1208.0 & 20.4 & 104.8 \\
\hline 8305-19 & 62 & 50700 & 2.3 & $\begin{array}{r}12.367 \\
1 \\
\end{array}$ & 1.9 & 2.3354 & 3.1 & 0.2095 & 2.5 & 0.79 & 1226.0 & 27.4 & 1223.1 & 22.1 & 1218.1 & 37.7 & 1218.1 & 37.7 & 100.7 \\
\hline $8305-92$ & 269 & $\begin{array}{r}20652 \\
4 \\
\end{array}$ & 1.8 & $\begin{array}{r}12.363 \\
7 \\
\end{array}$ & 0.4 & 2.3315 & 0.7 & 0.2091 & 0.5 & 0.74 & 1223.8 & 5.5 & 1221.9 & 4.7 & 1218.6 & 8.8 & 1218.6 & 8.8 & 100.4 \\
\hline $8305-87$ & 68 & 47096 & 2.0 & $\begin{array}{r}12.336 \\
2 \\
\end{array}$ & 1.3 & 2.3629 & 1.8 & 0.2114 & 1.2 & 0.68 & 1236.3 & 13.5 & 1231.4 & 12.6 & 1222.9 & 25.7 & 1222.9 & 25.7 & 101.1 \\
\hline $8305-23$ & 92 & 66115 & 1.1 & $\begin{array}{r}12.309 \\
9\end{array}$ & 1.3 & 2.3901 & 2.5 & 0.2134 & 2.1 & 0.86 & 1246.8 & 24.0 & 1239.6 & 17.7 & 1227.1 & 25.0 & 1227.1 & 25.0 & 101.6 \\
\hline
\end{tabular}




\begin{tabular}{|c|c|c|c|c|c|c|c|c|c|c|c|c|c|c|c|c|c|c|c|}
\hline Analysis & u & $206 \mathrm{~Pb}$ & $\begin{array}{c}\mathrm{U} / \mathrm{T} \\
\mathrm{h}\end{array}$ & $206 \mathrm{~Pb}^{*}$ & \pm & $207 \mathrm{~Pb}^{*}$ & \pm & $206 \mathrm{~Pb}$ & \pm & $\begin{array}{c}\text { erro } \\
\mathrm{r}\end{array}$ & $206 \mathrm{~Pb}$ & \pm & $207 \mathrm{~Pb}$ & \pm & $206 \mathrm{~Pb}$ & \pm & $\begin{array}{c}\text { Best } \\
\text { age }\end{array}$ & \pm & Conc \\
\hline & $\begin{array}{c}\text { (ppm } \\
\text { ) }\end{array}$ & $204 \mathrm{~Pb}$ & & $207 \mathrm{~Pb}^{*}$ & (\%) & $235 \mathrm{U}^{*}$ & (\%) & $238 \mathrm{U}$ & (\%) & corr. & $238 \mathrm{U}^{*}$ & (Ma) & $235 \mathrm{U}$ & (Ma) & $207 \mathrm{~Pb}$ & (Ma) & (Ma) & (Ma) & $(\%)$ \\
\hline $8305-60$ & 147 & $\begin{array}{r}17473 \\
3 \\
\end{array}$ & 1.6 & $\begin{array}{r}12.280 \\
7 \\
\end{array}$ & 0.9 & 2.3760 & 1.4 & 0.2116 & 1.0 & 0.72 & 1237.5 & 11.1 & 1235.4 & 9.8 & 1231.8 & 18.5 & 1231.8 & 18.5 & 100.5 \\
\hline $8305-65$ & 29 & 29511 & 2.0 & $\begin{array}{r}12.278 \\
4 \\
\end{array}$ & 4.6 & 2.3534 & 4.8 & 0.2096 & 1.5 & 0.31 & 1226.5 & 16.4 & 1228.6 & 34.1 & 1232.2 & 89.5 & 1232.2 & 89.5 & 99.5 \\
\hline $8305-45$ & 34 & 26468 & 0.5 & $\begin{array}{r}12.186 \\
8 \\
\end{array}$ & 2.1 & 2.3164 & 2.7 & 0.2047 & 1.7 & 0.64 & 1200.7 & 19.1 & 1217.3 & 19.3 & 1246.9 & 41.0 & 1246.9 & 41.0 & 96.3 \\
\hline $8305-81$ & 62 & 70276 & 1.5 & $\begin{array}{r}12.151 \\
4\end{array}$ & 2.0 & 2.3893 & 2.3 & 0.2106 & 1.1 & 0.49 & 1231.8 & 12.7 & 1239.4 & 16.4 & 1252.5 & 38.9 & 1252.5 & 38.9 & 98.3 \\
\hline $8305-20$ & 180 & $\begin{array}{r}11330 \\
9 \\
\end{array}$ & 1.4 & $\begin{array}{r}12.124 \\
8 \\
\end{array}$ & 0.9 & 2.3923 & 1.6 & 0.2104 & 1.3 & 0.83 & 1230.8 & 14.6 & 1240.3 & 11.2 & 1256.9 & 17.1 & 1256.9 & 17.1 & 97.9 \\
\hline $8305-55$ & 103 & 35865 & 3.2 & $\begin{array}{r}12.022 \\
6\end{array}$ & 1.3 & 2.3988 & 2.6 & 0.2092 & 2.2 & 0.87 & 1224.4 & 24.9 & 1242.2 & 18.4 & 1273.4 & 24.9 & 1273.4 & 24.9 & 96.2 \\
\hline $8305-5$ & 227 & 55574 & 3.2 & $\begin{array}{r}12.000 \\
1 \\
\end{array}$ & 3.8 & 2.4076 & 4.8 & 0.2095 & 2.9 & 0.60 & 1226.4 & 32.2 & 1244.9 & 34.3 & 1277.0 & 74.5 & 1277.0 & 74.5 & 96.0 \\
\hline $8305-70$ & 100 & 98134 & 1.4 & $\begin{array}{r}11.700 \\
2 \\
\end{array}$ & 1.6 & 2.7242 & 1.9 & 0.2312 & 0.9 & 0.48 & 1340.6 & 10.9 & 1335.1 & 13.9 & 1326.2 & 31.7 & 1326.2 & 31.7 & 101.1 \\
\hline $8305-52$ & 54 & 40809 & 0.8 & $\begin{array}{r}11.683 \\
1 \\
\end{array}$ & 2.1 & 2.7040 & 2.3 & 0.2291 & 1.0 & 0.45 & 1329.9 & 12.6 & 1329.5 & 17.2 & 1329.0 & 40.0 & 1329.0 & 40.0 & 100.1 \\
\hline $8305-79$ & 87 & 49341 & 1.5 & $\begin{array}{r}11.210 \\
6 \\
\end{array}$ & 1.3 & 2.9126 & 1.9 & 0.2368 & 1.5 & 0.75 & 1370.1 & 17.9 & 1385.2 & 14.6 & 1408.5 & 24.4 & 1408.5 & 24.4 & 97.3 \\
\hline $8305-54$ & 125 & 67594 & 1.8 & $\begin{array}{r}10.671 \\
9 \\
\end{array}$ & 0.5 & 3.3943 & 1.2 & 0.2627 & 1.1 & 0.92 & 1503.7 & 14.9 & 1503.1 & 9.5 & 1502.1 & 9.2 & 1502.1 & 9.2 & 100.1 \\
\hline $8305-72$ & 92 & 58251 & 1.2 & $\begin{array}{r}10.641 \\
2 \\
\end{array}$ & 1.2 & 3.4666 & 1.4 & 0.2675 & 0.7 & 0.52 & 1528.3 & 9.5 & 1519.6 & 10.6 & 1507.6 & 21.9 & 1507.6 & 21.9 & 101.4 \\
\hline $8305-34$ & 204 & $\begin{array}{r}23866 \\
7 \\
\end{array}$ & 2.0 & $\begin{array}{r}10.556 \\
6 \\
\end{array}$ & 0.6 & 3.4892 & 0.9 & 0.2671 & 0.6 & 0.73 & 1526.3 & 8.6 & 1524.8 & 6.9 & 1522.6 & 11.2 & 1522.6 & 11.2 & 100.2 \\
\hline $8305-44$ & 39 & 37465 & 0.8 & 9.6114 & 2.2 & 3.8607 & 6.1 & 0.2691 & 5.7 & 0.93 & 1536.4 & 77.7 & 1605.5 & 49.1 & 1697.4 & 40.2 & 1697.4 & 40.2 & 90.5 \\
\hline $8305-77$ & 56 & 43946 & 1.4 & 9.3026 & 1.6 & 4.6893 & 1.8 & 0.3164 & 0.8 & 0.46 & 1772.0 & 12.4 & 1765.3 & 14.7 & 1757.4 & 28.7 & 1757.4 & 28.7 & 100.8 \\
\hline $8305-53$ & 71 & 86851 & 0.9 & 8.7490 & 1.0 & 5.3961 & 1.4 & 0.3424 & 0.9 & 0.67 & 1898.2 & 15.2 & 1884.2 & 11.8 & 1868.8 & 18.3 & 1868.8 & 18.3 & 101.6 \\
\hline $8305-75$ & 180 & $\begin{array}{r}36882 \\
8 \\
\end{array}$ & 1.1 & 8.6674 & 0.3 & 5.4780 & 0.7 & 0.3444 & 0.6 & 0.87 & 1907.6 & 9.5 & 1897.2 & 5.7 & 1885.7 & 6.0 & 1885.7 & 6.0 & 101.2 \\
\hline $8305-84$ & 165 & $\begin{array}{r}13560 \\
2 \\
\end{array}$ & 0.7 & 8.1730 & 0.3 & 6.2462 & 0.8 & 0.3702 & 0.7 & 0.91 & 2030.6 & 11.9 & 2010.9 & 6.6 & 1990.8 & 5.6 & 1990.8 & 5.6 & 102.0 \\
\hline $8305-40$ & 197 & 36081 & 1.2 & 7.8954 & 0.5 & 5.6079 & 2.9 & 0.3211 & 2.9 & 0.99 & 1795.2 & 45.2 & 1917.3 & 25.2 & 2052.1 & 8.4 & 2052.1 & 8.4 & 87.5 \\
\hline $8305-24$ & 103 & 95704 & 2.3 & 7.8369 & 0.5 & 6.6700 & 1.3 & 0.3791 & 1.2 & 0.91 & 2072.1 & 21.4 & 2068.7 & 11.7 & 2065.2 & 9.7 & 2065.2 & 9.7 & 100.3 \\
\hline $8305-59$ & 78 & 89689 & 0.9 & 7.7233 & 0.6 & 6.8482 & 0.9 & 0.3836 & 0.7 & 0.77 & 2093.1 & 12.8 & 2092.0 & 8.3 & 2090.9 & 10.5 & 2090.9 & 10.5 & 100.1 \\
\hline $8305-6$ & 153 & 19797 & 0.9 & 7.5393 & 0.2 & 6.4560 & 2.1 & 0.3530 & 2.0 & 1.00 & 1949.0 & 34.4 & 2039.9 & 18.0 & 2133.2 & 2.8 & 2133.2 & 2.8 & 91.4 \\
\hline $8305-42$ & 104 & $\begin{array}{r}12822 \\
9 \\
\end{array}$ & 1.6 & 7.4415 & 0.3 & 7.2622 & 6.1 & 0.3919 & 6.1 & 1.00 & 2131.8 & $\begin{array}{r}110 . \\
1 \\
\end{array}$ & 2144.2 & 54.3 & 2156.0 & 5.8 & 2156.0 & 5.8 & 98.9 \\
\hline $8305-17$ & 43 & 39728 & 1.1 & 6.7472 & 1.2 & 8.6538 & 1.8 & 0.4235 & 1.3 & 0.74 & 2276.3 & 25.3 & 2302.2 & 16.3 & 2325.3 & 20.8 & 2325.3 & 20.8 & 97.9 \\
\hline $8305-21$ & 99 & $\begin{array}{r}18586 \\
3\end{array}$ & 3.9 & 6.2818 & 0.4 & 9.3673 & 1.1 & 0.4268 & 1.0 & 0.91 & 2291.1 & 19.2 & 2374.6 & 10.0 & 2447.1 & 7.5 & 2447.1 & 7.5 & 93.6 \\
\hline $8305-66$ & 137 & 27550 & 1.9 & 5.0813 & 0.2 & $\begin{array}{r}13.942 \\
2\end{array}$ & 0.8 & 0.5138 & 0.8 & 0.96 & 2672.9 & 16.7 & 2745.8 & 7.6 & 2799.8 & 3.7 & 2799.8 & 3.7 & 95.5 \\
\hline
\end{tabular}

\begin{tabular}{|c|c|c|c|c|c|c|c|c|c|c|c|c|c|c|c|c|c|c|c|}
\hline Analysis & u & $206 \mathrm{~Pb}$ & $\underset{\mathrm{h}}{\mathrm{U} / \mathrm{T}}$ & $206 \mathrm{~Pb}^{*}$ & \pm & $207 \mathrm{~Pb}^{*}$ & \pm & $206 \mathrm{~Pb}$ & \pm & $\underset{r}{\text { erro }}$ & $206 \mathrm{~Pb}$ & \pm & $207 \mathrm{~Pb}$ & \pm & 206 Pb & \pm & $\begin{array}{l}\text { Best } \\
\text { age }\end{array}$ & \pm & Conc \\
\hline & $\begin{array}{c}\text { (ppm } \\
\text { ) }\end{array}$ & $204 \mathrm{~Pb}$ & & $207 \mathrm{~Pb}^{*}$ & (\%) & $235 \mathrm{U}^{*}$ & (\%) & 2384 & $(\%)$ & corr. & $238 \mathrm{U}^{*}$ & (Ma) & $235 \mathrm{U}$ & (Ma) & 207Pb & (Ma) & (Ma) & (Ma) & (\%) \\
\hline FMG-90 & 242 & 52659 & 0.6 & $\begin{array}{r}16.948 \\
8 \\
\end{array}$ & 1.4 & 0.7021 & 1.7 & 0.0863 & 0.9 & 0.57 & 533.6 & 4.8 & 540.0 & 6.9 & 567.2 & 29.6 & 533.6 & 4.8 & 94.1 \\
\hline FMG-78 & 236 & 22796 & 0.5 & $\begin{array}{r}17.084 \\
2\end{array}$ & 1.9 & 0.7087 & 3.7 & 0.0878 & 3.2 & 0.86 & 542.6 & 16.6 & 543.9 & 15.7 & 549.8 & 42.1 & 542.6 & 16.6 & 98.7 \\
\hline FMG-75 & 299 & 40193 & 0.7 & $\begin{array}{r}17.131 \\
7 \\
\end{array}$ & 2.2 & 0.7112 & 2.6 & 0.0884 & 1.5 & 0.57 & 545.8 & 7.8 & 545.4 & 11.1 & 543.7 & 47.1 & 545.8 & 7.8 & 100.4 \\
\hline FMG-46 & 94 & 36771 & 1.0 & $\begin{array}{r}17.376 \\
2 \\
\end{array}$ & 5.4 & 0.7028 & 5.6 & 0.0886 & 1.3 & 0.24 & 547.1 & 7.1 & 540.4 & 23.4 & 512.6 & 119.0 & 547.1 & 7.1 & 106.7 \\
\hline FMG-79 & 297 & $\begin{array}{r}13685 \\
8\end{array}$ & 1.2 & $\begin{array}{r}17.132 \\
0\end{array}$ & 1.2 & 0.7134 & 2.6 & 0.0886 & 2.3 & 0.88 & 547.5 & 11.9 & 546.8 & 11.0 & 543.7 & 27.3 & 547.5 & 11.9 & 100.7 \\
\hline FMG-26 & 544 & 68216 & 1.4 & $\begin{array}{r}16.828 \\
0 \\
\end{array}$ & 0.8 & 0.7266 & 1.6 & 0.0887 & 1.4 & 0.86 & 547.7 & 7.5 & 554.6 & 7.0 & 582.7 & 18.0 & 547.7 & 7.5 & 94.0 \\
\hline FMG-64 & 168 & 46527 & 0.7 & $\begin{array}{r}17.138 \\
6\end{array}$ & 2.9 & 0.7180 & 3.1 & 0.0892 & 1.2 & 0.39 & 551.1 & 6.4 & 549.5 & 13.1 & 542.8 & 62.3 & 551.1 & 6.4 & 101.5 \\
\hline FMG-89 & 80 & 18376 & 1.1 & $\begin{array}{r}16.923 \\
5\end{array}$ & 2.5 & 0.7283 & 2.7 & 0.0894 & 0.8 & 0.32 & 552.0 & 4.5 & 555.6 & 11.4 & 570.4 & 55.0 & 552.0 & 4.5 & 96.8 \\
\hline FMG-96 & 100 & 24635 & 0.6 & $\begin{array}{r}17.406 \\
0 \\
\end{array}$ & 3.1 & 0.7134 & 3.4 & 0.0901 & 1.4 & 0.42 & 555.9 & 7.5 & 546.7 & 14.4 & 508.9 & 68.0 & 555.9 & 7.5 & 109.2 \\
\hline FMG-73 & 330 & $\begin{array}{r}14803 \\
6\end{array}$ & 0.9 & $\begin{array}{r}17.113 \\
5\end{array}$ & 1.6 & 0.7283 & 2.1 & 0.0904 & 1.4 & 0.64 & 557.9 & 7.3 & 555.6 & 9.2 & 546.0 & 35.9 & 557.9 & 7.3 & 102.2 \\
\hline
\end{tabular}




\begin{tabular}{|c|c|c|c|c|c|c|c|c|c|c|c|c|c|c|c|c|c|c|c|}
\hline Analysis & U & $206 \mathrm{~Pb}$ & $\begin{array}{c}\mathrm{U} / \mathrm{T} \\
\mathrm{h}\end{array}$ & $206 \mathrm{~Pb}^{*}$ & \pm & $207 \mathrm{~Pb}^{*}$ & \pm & $\underset{*}{206 \mathrm{~Pb}}$ & \pm & $\begin{array}{c}\text { erro } \\
\mathrm{r}\end{array}$ & $\underset{*}{206 \mathrm{~Pb}}$ & \pm & $\underset{*}{207 \mathrm{~Pb}}$ & \pm & $\underset{*}{206 \mathrm{~Pb}}$ & \pm & $\begin{array}{l}\text { Best } \\
\text { age }\end{array}$ & \pm & Conc \\
\hline & $\begin{array}{c}\text { (ppm } \\
\text { ) }\end{array}$ & $204 \mathrm{~Pb}$ & & $207 \mathrm{~Pb}^{*}$ & $(\%)$ & $235 \mathrm{U}^{*}$ & $(\%)$ & $238 \mathrm{U}$ & (\%) & corr. & $238 \mathrm{U}^{*}$ & (Ma) & $235 \mathrm{U}$ & (Ma) & $\underset{*}{207 \mathrm{~Pb}}$ & (Ma) & (Ma) & (Ma) & $(\%)$ \\
\hline FMG-84 & 435 & $\begin{array}{r}15130 \\
8\end{array}$ & 0.7 & $\begin{array}{r}17.130 \\
1\end{array}$ & 1.2 & 0.7326 & 1.4 & 0.0910 & 0.8 & 0.55 & 561.6 & 4.3 & 558.1 & 6.2 & 543.9 & 26.3 & 561.6 & 4.3 & 103.2 \\
\hline FMG-58 & 205 & 23760 & 0.7 & $\begin{array}{r}16.800 \\
2 \\
\end{array}$ & 3.4 & 0.7518 & 3.7 & 0.0916 & 1.4 & 0.38 & 565.0 & 7.7 & 569.3 & 16.2 & 586.3 & 74.7 & 565.0 & 7.7 & 96.4 \\
\hline FMG-27 & 297 & 75812 & 0.9 & $\begin{array}{r}17.132 \\
0 \\
\end{array}$ & 0.9 & 0.7375 & 1.2 & 0.0916 & 0.7 & 0.61 & 565.2 & 3.9 & 560.9 & 5.0 & 543.7 & 20.1 & 565.2 & 3.9 & 104.0 \\
\hline FMG-82 & 335 & 25760 & 1.1 & $\begin{array}{r}17.126 \\
1 \\
\end{array}$ & 0.8 & 0.7399 & 1.4 & 0.0919 & 1.2 & 0.82 & 566.8 & 6.5 & 562.4 & 6.2 & 544.5 & 18.0 & 566.8 & 6.5 & 104.1 \\
\hline FMG-57 & 158 & 66271 & 0.9 & $\begin{array}{r}17.015 \\
6\end{array}$ & 1.6 & 0.7451 & 1.9 & 0.0920 & 1.0 & 0.53 & 567.1 & 5.6 & 565.4 & 8.4 & 558.6 & 35.8 & 567.1 & 5.6 & 101.5 \\
\hline FMG-51 & 185 & 98578 & 4.3 & $\begin{array}{r}17.297 \\
8 \\
\end{array}$ & 1.3 & 0.7335 & 1.5 & 0.0920 & 0.7 & 0.49 & 567.5 & 3.9 & 558.6 & 6.3 & 522.6 & 28.2 & 567.5 & 3.9 & 108.6 \\
\hline FMG-65 & 55 & $\begin{array}{r}11378 \\
2 \\
\end{array}$ & 1.0 & $\begin{array}{r}16.641 \\
7 \\
\end{array}$ & 5.4 & 0.7639 & 5.6 & 0.0922 & 1.5 & 0.28 & 568.5 & 8.4 & 576.2 & 24.6 & 606.8 & 116.5 & 568.5 & 8.4 & 93.7 \\
\hline FMG-70 & 254 & 55386 & 2.5 & $\begin{array}{r}16.833 \\
6\end{array}$ & 1.9 & 0.7564 & 2.4 & 0.0923 & 1.6 & 0.64 & 569.4 & 8.5 & 571.9 & 10.6 & 582.0 & 40.3 & 569.4 & 8.5 & 97.8 \\
\hline FMG-25 & 217 & 70910 & 1.2 & $\begin{array}{r}17.090 \\
2 \\
\end{array}$ & 1.1 & 0.7454 & 1.6 & 0.0924 & 1.2 & 0.76 & 569.7 & 6.7 & 565.6 & 7.1 & 549.0 & 23.3 & 569.7 & 6.7 & 103.8 \\
\hline FMG-36 & 382 & $\begin{array}{r}10509 \\
9 \\
\end{array}$ & 17.3 & $\begin{array}{r}17.016 \\
6 \\
\end{array}$ & 0.9 & 0.7489 & 1.5 & 0.0924 & 1.1 & 0.77 & 569.9 & 6.1 & 567.6 & 6.3 & 558.5 & 20.1 & 569.9 & 6.1 & 102.0 \\
\hline FMG-87 & 55 & 12477 & 0.8 & $\begin{array}{r}16.676 \\
7 \\
\end{array}$ & 7.4 & 0.7647 & 7.6 & 0.0925 & 1.7 & 0.23 & 570.2 & 9.3 & 576.7 & 33.4 & 602.3 & 160.2 & 570.2 & 9.3 & 94.7 \\
\hline FMG-28 & 330 & 90821 & 1.1 & $\begin{array}{r}16.927 \\
6\end{array}$ & 0.8 & 0.7534 & 1.3 & 0.0925 & 1.0 & 0.80 & 570.3 & 5.5 & 570.2 & 5.5 & 569.9 & 16.7 & 570.3 & 5.5 & 100.1 \\
\hline FMG-6 & 190 & 34783 & 1.0 & $\begin{array}{r}17.037 \\
3 \\
\end{array}$ & 2.2 & 0.7502 & 2.9 & 0.0927 & 1.9 & 0.65 & 571.4 & 10.2 & 568.3 & 12.5 & 555.8 & 47.7 & 571.4 & 10.2 & 102.8 \\
\hline FMG-42 & 77 & 42065 & 1.2 & $\begin{array}{r}17.525 \\
1 \\
\end{array}$ & 7.3 & 0.7298 & 7.5 & 0.0928 & 1.5 & 0.20 & 571.8 & 8.2 & 556.4 & 32.0 & 493.9 & 161.6 & 571.8 & 8.2 & 115.8 \\
\hline FMG-21 & 146 & 35741 & 1.0 & $\begin{array}{r}16.917 \\
7 \\
\end{array}$ & 2.4 & 0.7575 & 2.7 & 0.0929 & 1.2 & 0.44 & 572.9 & 6.4 & 572.6 & 11.7 & 571.1 & 52.4 & 572.9 & 6.4 & 100.3 \\
\hline FMG-37 & 315 & 60949 & 1.3 & $\begin{array}{r}16.982 \\
8\end{array}$ & 1.4 & 0.7556 & 2.9 & 0.0931 & 2.5 & 0.88 & 573.7 & 14.0 & 571.5 & 12.6 & 562.8 & 29.7 & 573.7 & 14.0 & 101.9 \\
\hline FMG-12 & 431 & 37869 & 0.9 & $\begin{array}{r}16.983 \\
1\end{array}$ & 0.9 & 0.7589 & 3.5 & 0.0935 & 3.4 & 0.97 & 576.1 & 18.8 & 573.4 & 15.5 & 562.7 & 19.0 & 576.1 & 18.8 & 102.4 \\
\hline FMG-14 & 127 & 16794 & 1.3 & $\begin{array}{r}17.086 \\
0\end{array}$ & 2.3 & 0.7576 & 2.9 & 0.0939 & 1.8 & 0.60 & 578.5 & 9.8 & 572.6 & 12.8 & 549.6 & 50.7 & 578.5 & 9.8 & 105.3 \\
\hline FMG-76 & 439 & 10090 & 1.6 & $\begin{array}{r}16.547 \\
1 \\
\end{array}$ & 1.4 & 0.7824 & 2.3 & 0.0939 & 1.8 & 0.80 & 578.6 & 9.9 & 586.9 & 10.1 & 619.1 & 29.5 & 578.6 & 9.9 & 93.4 \\
\hline FMG-93 & 87 & 35901 & 2.6 & $\begin{array}{r}17.300 \\
3\end{array}$ & 4.7 & 0.7520 & 5.0 & 0.0944 & 1.6 & 0.33 & 581.3 & 9.1 & 569.4 & 21.8 & 522.3 & 103.7 & 581.3 & 9.1 & 111.3 \\
\hline FMG-67 & 404 & 5478 & 2.2 & $\begin{array}{r}16.163 \\
5\end{array}$ & 1.5 & 0.8076 & 2.2 & 0.0947 & 1.6 & 0.73 & 583.1 & 9.2 & 601.1 & 10.2 & 669.5 & 32.7 & 583.1 & 9.2 & 87.1 \\
\hline FMG-22 & 93 & 24154 & 0.9 & $\begin{array}{r}17.181 \\
3 \\
\end{array}$ & 5.7 & 0.7652 & 6.2 & 0.0954 & 2.5 & 0.40 & 587.1 & 13.9 & 577.0 & 27.3 & 537.4 & 124.8 & 587.1 & 13.9 & 109.2 \\
\hline FMG-11 & 104 & 38008 & 0.9 & $\begin{array}{r}16.551 \\
3\end{array}$ & 2.4 & 0.8058 & 2.6 & 0.0967 & 0.9 & 0.36 & 595.2 & 5.3 & 600.1 & 11.9 & 618.6 & 52.8 & 595.2 & 5.3 & 96.2 \\
\hline FMG-34 & 115 & 45030 & 1.1 & $\begin{array}{r}16.478 \\
6\end{array}$ & 3.0 & 0.8109 & 3.2 & 0.0969 & 1.1 & 0.35 & 596.3 & 6.4 & 603.0 & 14.7 & 628.1 & 65.6 & 596.3 & 6.4 & 94.9 \\
\hline FMG-69 & 42 & 13841 & 0.7 & $\begin{array}{r}17.996 \\
8\end{array}$ & 6.1 & 0.7426 & 6.3 & 0.0969 & 1.7 & 0.27 & 596.4 & 9.7 & 563.9 & 27.3 & 435.0 & 135.2 & 596.4 & 9.7 & 137.1 \\
\hline FMG-44 & 773 & 5981 & 0.8 & $\begin{array}{r}16.195 \\
4\end{array}$ & 1.5 & 0.8461 & 2.9 & 0.0994 & 2.4 & 0.85 & 610.8 & 14.1 & 622.5 & 13.3 & 665.3 & 32.2 & 610.8 & 14.1 & 91.8 \\
\hline FMG-86 & 58 & 20876 & 0.5 & $\begin{array}{r}16.762 \\
6\end{array}$ & 7.3 & 0.8269 & 7.5 & 0.1005 & 1.6 & 0.21 & 617.5 & 9.3 & 611.9 & 34.3 & 591.2 & 158.5 & 617.5 & 9.3 & 104.5 \\
\hline FMG-72 & 263 & $\begin{array}{r}16133 \\
7\end{array}$ & 1.4 & $\begin{array}{r}16.443 \\
5 \\
\end{array}$ & 1.5 & 0.8433 & 1.7 & 0.1006 & 0.6 & 0.38 & 617.8 & 3.7 & 621.0 & 7.7 & 632.7 & 33.2 & 617.8 & 3.7 & 97.6 \\
\hline FMG-40 & 431 & $\begin{array}{r}21521 \\
3\end{array}$ & 0.2 & $\begin{array}{r}16.624 \\
4\end{array}$ & 0.8 & 0.8361 & 1.9 & 0.1008 & 1.7 & 0.91 & 619.2 & 10.3 & 617.0 & 8.8 & 609.0 & 17.1 & 619.2 & 10.3 & 101.7 \\
\hline FMG-9 & 344 & 2312 & 0.9 & $\begin{array}{r}16.529 \\
8\end{array}$ & 2.1 & 0.8431 & 4.7 & 0.1011 & 4.2 & 0.89 & 620.7 & 24.7 & 620.9 & 21.7 & 621.4 & 45.6 & 620.7 & 24.7 & 99.9 \\
\hline FMG- 15 & 112 & 26625 & 0.7 & $\begin{array}{r}16.609 \\
3 \\
\end{array}$ & 1.7 & 0.8418 & 2.3 & 0.1014 & 1.6 & 0.68 & 622.6 & 9.4 & 620.1 & 10.8 & 611.0 & 36.6 & 622.6 & 9.4 & 101.9 \\
\hline FMG-39 & 249 & 19097 & 5.1 & $\begin{array}{r}16.734 \\
0\end{array}$ & 1.7 & 0.8367 & 5.1 & 0.1015 & 4.8 & 0.94 & 623.5 & 28.2 & 617.3 & 23.4 & 594.9 & 37.2 & 623.5 & 28.2 & 104.8 \\
\hline FMG-97 & 510 & 28425 & 0.6 & $\begin{array}{r}16.509 \\
5\end{array}$ & 1.0 & 0.8517 & 2.0 & 0.1020 & 1.7 & 0.87 & 626.0 & 10.2 & 625.6 & 9.2 & 624.0 & 21.2 & 626.0 & 10.2 & 100.3 \\
\hline FMG-99 & 298 & 61562 & 0.9 & $\begin{array}{r}16.614 \\
5\end{array}$ & 1.2 & 0.8482 & 1.5 & 0.1022 & 0.9 & 0.62 & 627.4 & 5.6 & 623.7 & 7.1 & 610.3 & 25.8 & 627.4 & 5.6 & 102.8 \\
\hline FMG-35 & 82 & 24653 & 1.0 & $\begin{array}{r}16.253 \\
9\end{array}$ & 2.6 & 0.8704 & 3.1 & 0.1026 & 1.6 & 0.52 & 629.6 & 9.4 & 635.8 & 14.4 & 657.6 & 56.1 & 629.6 & 9.4 & 95.7 \\
\hline FMG- 16 & 50 & 9815 & 1.2 & $\begin{array}{r}16.368 \\
1\end{array}$ & 8.8 & 0.8657 & 9.0 & 0.1028 & 1.6 & 0.17 & 630.6 & 9.4 & 633.2 & 42.2 & 642.6 & 189.8 & 630.6 & 9.4 & 98.1 \\
\hline FMG-61 & 161 & 73680 & 1.6 & $\begin{array}{r}16.474 \\
8\end{array}$ & 1.8 & 0.8636 & 2.4 & 0.1032 & 1.5 & 0.64 & 633.0 & 9.1 & 632.1 & 11.2 & 628.6 & 39.6 & 633.0 & 9.1 & 100.7 \\
\hline FMG-85 & 214 & 72942 & 1.5 & $\begin{array}{r}16.314 \\
0\end{array}$ & 1.3 & 0.8724 & 2.0 & 0.1032 & 1.6 & 0.77 & 633.3 & 9.4 & 636.9 & 9.6 & 649.7 & 27.8 & 633.3 & 9.4 & 97.5 \\
\hline FMG-33 & 189 & 42642 & 1.9 & $\begin{array}{r}16.584 \\
6\end{array}$ & 1.4 & 0.8647 & 1.6 & 0.1040 & 0.8 & 0.48 & 637.9 & 4.7 & 632.7 & 7.5 & 614.2 & 30.4 & 637.9 & 4.7 & 103.9 \\
\hline
\end{tabular}




\begin{tabular}{|c|c|c|c|c|c|c|c|c|c|c|c|c|c|c|c|c|c|c|c|}
\hline Analysis & $u$ & $206 \mathrm{~Pb}$ & $\begin{array}{c}\mathrm{U} / \mathrm{T} \\
\mathrm{h}\end{array}$ & $206 \mathrm{~Pb}^{*}$ & \pm & $207 \mathrm{~Pb}^{*}$ & \pm & $206 \mathrm{~Pb}$ & \pm & $\begin{array}{c}\text { erro } \\
\mathrm{r}\end{array}$ & $206 \mathrm{~Pb}$ & \pm & $207 \mathrm{~Pb}$ & \pm & $206 \mathrm{~Pb}$ & \pm & $\begin{array}{l}\text { Best } \\
\text { age }\end{array}$ & \pm & Conc \\
\hline & $\begin{array}{c}\text { (ppm } \\
\text { ) }\end{array}$ & $204 \mathrm{~Pb}$ & & $207 \mathrm{~Pb}^{*}$ & (\%) & $235 \mathrm{U}^{*}$ & (\%) & $238 \mathrm{U}$ & (\%) & corr. & $238 \mathrm{U}^{*}$ & (Ma) & $235 \mathrm{U}$ & (Ma) & $\underset{*}{207 \mathrm{~Pb}}$ & (Ma) & (Ma) & (Ma) & (\%) \\
\hline FMG-29 & 362 & $\begin{array}{r}10176 \\
6 \\
\end{array}$ & 1.3 & $\begin{array}{r}16.479 \\
4 \\
\end{array}$ & 0.5 & 0.8801 & 1.2 & 0.1052 & 1.0 & 0.91 & 644.8 & 6.4 & 641.0 & 5.5 & 628.0 & 10.5 & 644.8 & 6.4 & 102.7 \\
\hline FMG-24 & 235 & 28937 & 3.7 & $\begin{array}{r}15.867 \\
0 \\
\end{array}$ & 2.2 & 0.9313 & 6.5 & 0.1072 & 6.1 & 0.94 & 656.3 & 38.1 & 668.3 & 31.7 & 709.0 & 46.7 & 656.3 & 38.1 & 92.6 \\
\hline FMG-50 & 226 & 74772 & 0.7 & $\begin{array}{r}16.375 \\
8 \\
\end{array}$ & 0.9 & 0.9047 & 1.1 & 0.1074 & 0.7 & 0.65 & 657.9 & 4.6 & 654.2 & 5.4 & 641.6 & 18.4 & 657.9 & 4.6 & 102.5 \\
\hline FMG-19 & 63 & 42622 & 2.0 & $\begin{array}{r}16.032 \\
3 \\
\end{array}$ & 4.6 & 0.9362 & 5.3 & 0.1089 & 2.6 & 0.49 & 666.1 & 16.5 & 670.9 & 25.9 & 687.0 & 97.8 & 666.1 & 16.5 & 97.0 \\
\hline FMG-38 & 264 & $\begin{array}{r}1269 \\
1 \\
\end{array}$ & 0.5 & $\begin{array}{r}16.044 \\
1 \\
\end{array}$ & 1.4 & 0.9811 & 1.6 & 0.1142 & 0.7 & 0.47 & 696.9 & 4.9 & 694.2 & 7.9 & 685.4 & 29.6 & 696.9 & 4.9 & 101.7 \\
\hline FMG-7 & 131 & 43101 & 1.1 & $\begin{array}{r}15.763 \\
5 \\
\end{array}$ & 2.2 & 1.0310 & 2.6 & 0.1179 & 1.4 & 0.54 & 718.3 & 9.5 & 719.4 & 13.2 & 722.9 & 45.7 & 718.3 & 9.5 & 99.4 \\
\hline FMG-32 & 276 & $\begin{array}{r}16658 \\
4 \\
\end{array}$ & 1.1 & $\begin{array}{r}13.650 \\
6 \\
\end{array}$ & 0.6 & 1.7161 & 1.8 & 0.1699 & 1.7 & 0.95 & 1011.6 & 15.8 & 1014.6 & 11.4 & 1021.0 & 11.2 & 1021.0 & 11.2 & 99.1 \\
\hline FMG-2 & 336 & $\begin{array}{r}11431 \\
6 \\
\end{array}$ & 5.1 & $\begin{array}{r}13.344 \\
1\end{array}$ & 0.3 & 1.9058 & 0.8 & 0.1844 & 0.7 & 0.90 & 1091.2 & 7.2 & 1083.1 & 5.3 & 1066.9 & 7.0 & 1066.9 & 7.0 & 102.3 \\
\hline FMG-98 & 79 & 36433 & 1.6 & $\begin{array}{r}12.345 \\
0 \\
\end{array}$ & 1.1 & 2.4269 & 1.4 & 0.2173 & 0.8 & 0.61 & 1267.6 & 9.8 & 1250.6 & 10.1 & 1221.6 & 21.9 & 1221.6 & 21.9 & 103.8 \\
\hline FMG-80 & 107 & 31608 & 2.4 & $\begin{array}{r}12.111 \\
1 \\
\end{array}$ & 3.0 & 2.4742 & 5.4 & 0.2173 & 4.5 & 0.83 & 1267.7 & 51.8 & 1264.5 & 39.3 & 1259.1 & 59.5 & 1259.1 & 59.5 & 100.7 \\
\hline FMG-100 & 156 & $\begin{array}{r}10345 \\
8 \\
\end{array}$ & 1.5 & 9.3280 & 0.7 & 4.4927 & 1.1 & 0.3039 & 0.8 & 0.79 & 1710.8 & 12.6 & 1729.6 & 8.8 & 1752.4 & 11.9 & 1752.4 & 11.9 & 97.6 \\
\hline FMG-88 & 202 & $\begin{array}{r}23298 \\
0 \\
\end{array}$ & 2.1 & 9.2668 & 0.4 & 4.7493 & 0.9 & 0.3192 & 0.9 & 0.92 & 1785.8 & 13.3 & 1776.0 & 7.8 & 1764.5 & 6.8 & 1764.5 & 6.8 & 101.2 \\
\hline FMG-20 & 837 & 26429 & 32.1 & 7.9585 & 0.3 & 5.3249 & 2.6 & 0.3074 & 2.6 & 1.00 & 1727.7 & 39.7 & 1872.9 & 22.5 & 2038.0 & 4.6 & 2038.0 & 4.6 & 84.8 \\
\hline FMG-66 & 196 & $\begin{array}{r}30179 \\
6 \\
\end{array}$ & 13.2 & 7.7877 & 0.4 & 5.8155 & 1.9 & 0.3285 & 1.8 & 0.98 & 1830.9 & 29.1 & 1948.7 & 16.1 & 2076.3 & 6.5 & 2076.3 & 6.5 & 88.2 \\
\hline FMG-71 & 234 & $\begin{array}{r}21890 \\
7\end{array}$ & 4.3 & 7.7530 & 0.7 & 6.8524 & 0.9 & 0.3853 & 0.5 & 0.62 & 2101.1 & 9.6 & 2092.5 & 7.6 & 2084.1 & 11.9 & 2084.1 & 11.9 & 100.8 \\
\hline FMG-91 & 78 & $\begin{array}{r}12773 \\
0 \\
\end{array}$ & 1.1 & 7.7135 & 0.6 & 6.8290 & 1.0 & 0.3820 & 0.8 & 0.79 & 2085.8 & 13.4 & 2089.5 & 8.4 & 2093.1 & 10.2 & 2093.1 & 10.2 & 99.7 \\
\hline FMG-31 & 84 & 63439 & 1.6 & 7.6686 & 0.5 & 7.1802 & 0.7 & 0.3993 & 0.5 & 0.72 & 2166.0 & 9.7 & 2134.0 & 6.5 & 2103.4 & 8.9 & 2103.4 & 8.9 & 103.0 \\
\hline FMG-74 & 302 & $\begin{array}{r}39027 \\
4 \\
\end{array}$ & 1.9 & 7.5686 & 0.3 & 7.1428 & 1.4 & 0.3921 & 1.4 & 0.98 & 2132.5 & 25.6 & 2129.4 & 12.8 & 2126.4 & 4.9 & 2126.4 & 4.9 & 100.3 \\
\hline FMG-47 & 60 & 64050 & 1.4 & 7.3031 & 0.6 & 7.1760 & 1.4 & 0.3801 & 1.3 & 0.89 & 2076.7 & 22.6 & 2133.5 & 12.7 & 2188.7 & 11.2 & 2188.7 & 11.2 & 94.9 \\
\hline FMG-8 & 36 & 18123 & 1.5 & 6.8442 & 1.1 & 9.0467 & 1.5 & 0.4491 & 1.1 & 0.72 & 2391.1 & 22.0 & 2342.7 & 14.0 & 2300.9 & 18.2 & 2300.9 & 18.2 & 103.9 \\
\hline FMG-41 & 350 & 28370 & 2.8 & 5.5501 & 0.2 & $\begin{array}{r}11.045 \\
8 \\
\end{array}$ & 2.1 & 0.4446 & 2.1 & 1.00 & 2371.3 & 42.4 & 2527.0 & 20.0 & 2654.5 & 3.0 & 2654.5 & 3.0 & 89.3 \\
\hline FMG-17 & 561 & $\begin{array}{r}48279 \\
9 \\
\end{array}$ & 5.2 & 5.2857 & 0.2 & $\begin{array}{r}13.233 \\
5 \\
\end{array}$ & 1.3 & 0.5073 & 1.3 & 0.98 & 2645.2 & 27.7 & 2696.4 & 12.3 & 2735.1 & 3.9 & 2735.1 & 3.9 & 96.7 \\
\hline FMG-62 & 448 & $\begin{array}{r}10721 \\
0 \\
\end{array}$ & 1.5 & 5.0315 & 0.7 & $\begin{array}{r}13.378 \\
8 \\
\end{array}$ & 1.7 & 0.4882 & 1.5 & 0.92 & 2562.9 & 32.6 & 2706.8 & 15.9 & 2815.9 & 10.9 & 2815.9 & 10.9 & 91.0 \\
\hline
\end{tabular}

\begin{tabular}{|c|c|c|c|c|c|c|c|c|c|c|c|c|c|c|c|c|c|c|c|}
\hline Analysis & U & $206 \mathrm{~Pb}$ & $\begin{array}{c}\mathrm{U} / \mathrm{T} \\
\mathrm{h}\end{array}$ & $206 \mathrm{~Pb}^{*}$ & \pm & $207 \mathrm{~Pb}^{*}$ & \pm & $206 \mathrm{~Pb}$ & \pm & $\begin{array}{c}\text { erro } \\
\mathrm{r}\end{array}$ & $206 \mathrm{~Pb}$ & \pm & $207 \mathrm{~Pb}$ & \pm & $206 \mathrm{~Pb}$ & \pm & $\begin{array}{c}\text { Best } \\
\text { age }\end{array}$ & \pm & Conc \\
\hline & $\begin{array}{c}\text { (ppm } \\
)\end{array}$ & $204 \mathrm{~Pb}$ & & $207 \mathrm{~Pb}^{*}$ & $(\%)$ & $235 \mathrm{U}^{*}$ & $(\%)$ & $238 U$ & (\%) & corr. & $238 \mathrm{U}^{*}$ & (Ma) & $235 \mathrm{U}$ & (Ma) & $207 \mathrm{~Pb}$ & (Ma) & (Ma) & (Ma) & (\%) \\
\hline MO-4 & 89 & 11982 & 1.1 & $\begin{array}{r}19.902 \\
6 \\
\end{array}$ & 8.1 & 0.4214 & 8.4 & 0.0608 & 2.0 & 0.24 & 380.6 & 7.3 & 357.0 & 25.2 & 206.3 & 189.3 & 380.6 & 7.3 & NA \\
\hline MO-5 & 301 & 78024 & 0.9 & $\begin{array}{r}16.610 \\
5 \\
\end{array}$ & 1.3 & 0.8444 & 1.9 & 0.1017 & 1.4 & 0.72 & 624.5 & 8.2 & 621.6 & 8.9 & 610.9 & 28.5 & 624.5 & 8.2 & 102.2 \\
\hline MO-6 & 521 & $\begin{array}{r}30037 \\
7 \\
\end{array}$ & 1.5 & $\begin{array}{r}12.709 \\
6 \\
\end{array}$ & 0.4 & 2.1812 & 1.1 & 0.2011 & 1.0 & 0.94 & 1181.0 & 10.7 & 1175.1 & 7.4 & 1164.1 & 7.2 & 1164.1 & 7.2 & 101.5 \\
\hline MO-7 & 218 & 51508 & 1.5 & $\begin{array}{r}18.491 \\
2 \\
\end{array}$ & 2.4 & 0.4842 & 2.5 & 0.0649 & 0.9 & 0.35 & 405.6 & 3.4 & 401.0 & 8.4 & 374.4 & 53.3 & 405.6 & 3.4 & 108.3 \\
\hline MO-8 & 27 & 56058 & 0.4 & 5.3631 & 1.2 & 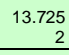 & 2.0 & 0.5339 & 1.6 & 0.80 & 2757.7 & 36.3 & 2730.9 & 19.0 & 2711.2 & 19.8 & 2711.2 & 19.8 & 101.7 \\
\hline MO-9 & 49 & 44779 & 2.0 & $\begin{array}{r}14.319 \\
4 \\
\end{array}$ & 4.5 & 1.5056 & 4.7 & 0.1564 & 1.1 & 0.24 & 936.5 & 9.7 & 932.7 & 28.4 & 923.5 & 92.8 & 923.5 & 92.8 & 101.4 \\
\hline MO-10 & 65 & 35674 & 1.0 & $\begin{array}{r}13.503 \\
9 \\
\end{array}$ & 3.0 & 1.8372 & 3.3 & 0.1799 & 1.4 & 0.41 & 1066.6 & 13.3 & 1058.9 & 21.9 & 1042.9 & 61.4 & 1042.9 & 61.4 & 102.3 \\
\hline MO-11 & 254 & 33080 & 1.0 & $\begin{array}{r}18.604 \\
3 \\
\end{array}$ & 2.5 & 0.4388 & 2.9 & 0.0592 & 1.4 & 0.50 & 370.8 & 5.2 & 369.4 & 8.9 & 360.6 & 56.4 & 370.8 & 5.2 & $\mathrm{NA}$ \\
\hline MO-12 & 131 & $\begin{array}{r}33243 \\
8 \\
\end{array}$ & 1.5 & 3.4852 & 0.4 & $\begin{array}{r}23.926 \\
0 \\
\end{array}$ & 2.4 & 0.6048 & 2.3 & 0.98 & 3049.0 & 56.8 & 3265.4 & 23.2 & 3401.0 & 6.7 & 3401.0 & 6.7 & 89.7 \\
\hline MO-13 & 180 & 78992 & 1.8 & $\begin{array}{r}13.985 \\
9 \\
\end{array}$ & 1.3 & 1.6258 & 1.6 & 0.1649 & 1.0 & 0.63 & 984.0 & 9.4 & 980.2 & 10.2 & 971.7 & 25.6 & 971.7 & 25.6 & 101.3 \\
\hline MO-14 & 200 & 84656 & 1.8 & $\begin{array}{r}12.397 \\
2 \\
\end{array}$ & 0.7 & 2.4162 & 1.4 & 0.2172 & 1.2 & 0.88 & 1267.3 & 14.4 & 1247.4 & 10.2 & 1213.2 & 13.2 & 1213.2 & 13.2 & 104.5 \\
\hline MO-15 & 181 & 80122 & 4.8 & $\begin{array}{r}18.489 \\
6 \\
\end{array}$ & 4.7 & 0.4984 & 4.9 & 0.0668 & 1.6 & 0.33 & 417.0 & 6.6 & 410.6 & 16.7 & 374.5 & 105.1 & 417.0 & 6.6 & 111.3 \\
\hline MO-16 & 72 & 24916 & 1.6 & $\begin{array}{r}16.364 \\
3\end{array}$ & 3.2 & 0.8824 & 3.4 & 0.1047 & 1.1 & 0.32 & 642.0 & 6.7 & 642.3 & 16.0 & 643.1 & 68.6 & 642.0 & 6.7 & 99.8 \\
\hline
\end{tabular}




\begin{tabular}{|c|c|c|c|c|c|c|c|c|c|c|c|c|c|c|c|c|c|c|c|}
\hline Analysis & U & $206 \mathrm{~Pb}$ & $\begin{array}{c}\mathrm{U} / \mathrm{T} \\
\mathrm{h}\end{array}$ & $206 \mathrm{~Pb}^{*}$ & \pm & $207 \mathrm{~Pb}^{*}$ & \pm & $\underset{*}{206 \mathrm{~Pb}}$ & \pm & $\begin{array}{c}\text { erro } \\
\mathrm{r}\end{array}$ & $\underset{*}{206 \mathrm{~Pb}}$ & \pm & $\underset{*}{207 \mathrm{~Pb}}$ & \pm & $\underset{*}{206 \mathrm{~Pb}}$ & \pm & $\begin{array}{l}\text { Best } \\
\text { age }\end{array}$ & \pm & Conc \\
\hline & $\begin{array}{c}\text { (ppm } \\
\text { ) }\end{array}$ & $204 \mathrm{~Pb}$ & & $207 \mathrm{~Pb}^{*}$ & $(\%)$ & $235 \mathrm{U}^{*}$ & $(\%)$ & $238 \mathrm{U}$ & $(\%)$ & corr. & $238 \mathrm{U}^{*}$ & (Ma) & $235 \mathrm{U}$ & (Ma) & $\underset{*}{207 \mathrm{~Pb}}$ & (Ma) & (Ma) & (Ma) & $(\%)$ \\
\hline MO-17 & 204 & 62516 & 1.7 & $\begin{array}{r}13.009 \\
7\end{array}$ & 1.1 & 2.0512 & 2.1 & 0.1935 & 1.8 & 0.85 & 1140.5 & 18.6 & 1132.7 & 14.3 & 1117.7 & 22.1 & 1117.7 & 22.1 & 102.0 \\
\hline MO-19 & 159 & 24009 & 0.7 & $\begin{array}{r}13.498 \\
8 \\
\end{array}$ & 1.1 & 1.7057 & 1.2 & 0.1670 & 0.6 & 0.48 & 995.5 & 5.4 & 1010.7 & 7.9 & 1043.7 & 21.9 & 1043.7 & 21.9 & 95.4 \\
\hline MO-20 & 450 & $\begin{array}{r}61260 \\
5 \\
\end{array}$ & 2.5 & $\begin{array}{r}13.393 \\
8 \\
\end{array}$ & 0.4 & 1.8534 & 0.8 & 0.1800 & 0.7 & 0.89 & 1067.2 & 7.0 & 1064.6 & 5.3 & 1059.4 & 7.3 & 1059.4 & 7.3 & 100.7 \\
\hline MO-21 & 288 & $\begin{array}{r}24347 \\
5 \\
\end{array}$ & 1.1 & $\begin{array}{r}13.304 \\
0 \\
\end{array}$ & 0.9 & 1.8591 & 1.1 & 0.1794 & 0.6 & 0.52 & 1063.6 & 5.7 & 1066.7 & 7.3 & 1072.9 & 19.0 & 1072.9 & 19.0 & 99.1 \\
\hline MO-22 & 135 & 84011 & 1.7 & $\begin{array}{r}12.681 \\
7\end{array}$ & 0.7 & 2.1302 & 2.3 & 0.1959 & 2.2 & 0.95 & 1153.4 & 23.0 & 1158.6 & 15.8 & 1168.5 & 13.9 & 1168.5 & 13.9 & 98.7 \\
\hline MO-23 & 64 & 37774 & 1.8 & $\begin{array}{r}12.012 \\
7 \\
\end{array}$ & 1.4 & 2.4998 & 1.6 & 0.2178 & 0.6 & 0.41 & 1270.2 & 7.3 & 1272.0 & 11.3 & 1275.0 & 27.8 & 1275.0 & 27.8 & 99.6 \\
\hline MO-24 & 102 & 22821 & 1.4 & $\begin{array}{r}17.913 \\
0 \\
\end{array}$ & 4.4 & 0.5567 & 4.7 & 0.0723 & 1.5 & 0.32 & 450.2 & 6.4 & 449.4 & 16.9 & 445.4 & 98.1 & 450.2 & 6.4 & 101.1 \\
\hline MO-25 & 222 & 34460 & 6.8 & $\begin{array}{r}18.627 \\
7\end{array}$ & 2.3 & 0.4627 & 2.6 & 0.0625 & 1.2 & 0.47 & 390.9 & 4.6 & 386.1 & 8.2 & 357.8 & 51.1 & 390.9 & 4.6 & NA \\
\hline MO-26 & 57 & 38640 & 1.8 & $\begin{array}{r}12.873 \\
9 \\
\end{array}$ & 2.4 & 2.0002 & 2.7 & 0.1868 & 1.3 & 0.49 & 1103.8 & 13.4 & 1115.6 & 18.3 & 1138.6 & 46.8 & 1138.6 & 46.8 & 96.9 \\
\hline MO-27 & 318 & $\begin{array}{r}12879 \\
0 \\
\end{array}$ & 2.4 & $\begin{array}{r}13.342 \\
0 \\
\end{array}$ & 0.6 & 1.8758 & 1.1 & 0.1815 & 1.0 & 0.85 & 1075.2 & 9.6 & 1072.6 & 7.5 & 1067.2 & 12.0 & 1067.2 & 12.0 & 100.8 \\
\hline MO-28 & 53 & 42973 & 1.7 & $\begin{array}{r}11.270 \\
7 \\
\end{array}$ & 1.8 & 2.9818 & 2.1 & 0.2437 & 1.1 & 0.53 & 1406.1 & 13.8 & 1403.0 & 15.8 & 1398.2 & 33.9 & 1398.2 & 33.9 & 100.6 \\
\hline MO-29 & 26 & 16392 & 1.1 & $\begin{array}{r}13.610 \\
0\end{array}$ & 6.6 & 1.7268 & 6.8 & 0.1705 & 1.7 & 0.25 & 1014.6 & 15.8 & 1018.6 & 43.9 & 1027.1 & 134.0 & 1027.1 & $\begin{array}{r}134 . \\
0\end{array}$ & 98.8 \\
\hline MO-30 & 169 & $\begin{array}{r}13476 \\
2 \\
\end{array}$ & 4.2 & $\begin{array}{r}12.546 \\
4\end{array}$ & 1.1 & 2.2276 & 1.4 & 0.2027 & 0.9 & 0.62 & 1189.8 & 9.8 & 1189.8 & 10.1 & 1189.7 & 22.3 & 1189.7 & 22.3 & 100.0 \\
\hline MO-31 & 118 & 63387 & 0.7 & $\begin{array}{r}16.535 \\
1 \\
\end{array}$ & 2.7 & 0.8505 & 2.8 & 0.1020 & 0.8 & 0.27 & 626.1 & 4.5 & 624.9 & 13.0 & 620.7 & 57.8 & 626.1 & 4.5 & 100.9 \\
\hline MO-33 & 342 & $\begin{array}{r}14115 \\
4 \\
\end{array}$ & 3.1 & $\begin{array}{r}13.718 \\
8 \\
\end{array}$ & 0.5 & 1.7316 & 1.1 & 0.1723 & 1.0 & 0.89 & 1024.7 & 9.3 & 1020.3 & 7.1 & 1011.0 & 10.2 & 1011.0 & 10.2 & 101.4 \\
\hline MO-34 & 53 & 33380 & 3.4 & $\begin{array}{r}13.685 \\
8 \\
\end{array}$ & 3.2 & 1.7547 & 3.6 & 0.1742 & 1.7 & 0.47 & 1035.0 & 16.2 & 1028.9 & 23.1 & 1015.8 & 63.9 & 1015.8 & 63.9 & 101.9 \\
\hline MO-35 & 57 & 33969 & 1.8 & $\begin{array}{r}12.030 \\
7\end{array}$ & 3.0 & 2.5005 & 3.3 & 0.2182 & 1.2 & 0.38 & 1272.2 & 14.4 & 1272.2 & 23.8 & 1272.0 & 59.2 & 1272.0 & 59.2 & 100.0 \\
\hline MO-37 & 207 & $\begin{array}{r}10441 \\
8 \\
\end{array}$ & 4.6 & $\begin{array}{r}13.530 \\
5\end{array}$ & 1.1 & 1.7958 & 1.8 & 0.1762 & 1.5 & 0.80 & 1046.3 & 14.2 & 1043.9 & 12.0 & 1038.9 & 22.5 & 1038.9 & 22.5 & 100.7 \\
\hline MO-38 & 180 & 98701 & 1.6 & $\begin{array}{r}16.809 \\
4 \\
\end{array}$ & 1.8 & 0.7750 & 2.5 & 0.0945 & 1.7 & 0.68 & 582.0 & 9.4 & 582.6 & 11.0 & 585.1 & 39.8 & 582.0 & 9.4 & 99.5 \\
\hline MO-39 & 164 & 86817 & 3.1 & $\begin{array}{r}13.484 \\
8\end{array}$ & 1.2 & 1.8341 & 3.3 & 0.1794 & 3.1 & 0.93 & 1063.6 & 30.1 & 1057.7 & 21.8 & 1045.8 & 25.1 & 1045.8 & 25.1 & 101.7 \\
\hline MO-40 & 133 & $\begin{array}{r}10625 \\
4\end{array}$ & 1.2 & 9.7186 & 0.4 & 4.2957 & 1.0 & 0.3028 & 0.9 & 0.93 & 1705.1 & 14.2 & 1692.5 & 8.4 & 1677.0 & 7.1 & 1677.0 & 7.1 & 101.7 \\
\hline MO-41 & 417 & $\begin{array}{r}11611 \\
6 \\
\end{array}$ & 12.7 & $\begin{array}{r}13.937 \\
9 \\
\end{array}$ & 0.6 & 1.5821 & 1.6 & 0.1599 & 1.5 & 0.92 & 956.4 & 12.9 & 963.2 & 9.8 & 978.7 & 12.4 & 978.7 & 12.4 & 97.7 \\
\hline MO-43 & 65 & 54026 & 1.8 & $\begin{array}{r}13.673 \\
4 \\
\end{array}$ & 2.6 & 1.7428 & 2.9 & 0.1728 & 1.3 & 0.46 & 1027.7 & 12.7 & 1024.5 & 18.6 & 1017.7 & 51.8 & 1017.7 & 51.8 & 101.0 \\
\hline MO-44 & 93 & 20207 & 0.4 & $\begin{array}{r}19.644 \\
5\end{array}$ & $\begin{array}{r}11 . \\
9\end{array}$ & 0.3653 & $\begin{array}{r}12 . \\
1\end{array}$ & 0.0520 & 2.0 & 0.17 & 327.1 & 6.4 & 316.2 & 32.9 & 236.5 & 276.0 & 327.1 & 6.4 & NA \\
\hline MO-46 & 63 & 33895 & 1.1 & $\begin{array}{r}12.934 \\
3 \\
\end{array}$ & 1.1 & 2.1032 & 2.7 & 0.1973 & 2.4 & 0.90 & 1160.8 & 25.5 & 1149.8 & 18.3 & 1129.3 & 22.7 & 1129.3 & 22.7 & 102.8 \\
\hline MO-47 & 115 & $\begin{array}{r}15567 \\
1 \\
\end{array}$ & 1.7 & $\begin{array}{r}10.917 \\
8\end{array}$ & 0.4 & 3.1645 & 1.5 & 0.2506 & 1.5 & 0.97 & 1441.5 & 18.9 & 1448.5 & 11.7 & 1458.9 & 7.4 & 1458.9 & 7.4 & 98.8 \\
\hline MO-48 & 128 & 46899 & 0.4 & $\begin{array}{r}17.822 \\
1\end{array}$ & 4.1 & 0.5205 & 4.3 & 0.0673 & 1.2 & 0.27 & 419.7 & 4.7 & 425.5 & 15.0 & 456.7 & 91.9 & 419.7 & 4.7 & 91.9 \\
\hline MO-49 & 67 & 40874 & 2.2 & $\begin{array}{r}13.386 \\
0 \\
\end{array}$ & 2.6 & 1.7617 & 7.8 & 0.1710 & 7.4 & 0.94 & 1017.8 & 69.4 & 1031.5 & 50.6 & 1060.6 & 51.8 & 1060.6 & 51.8 & 96.0 \\
\hline MO-51 & 89 & 37553 & 2.7 & $\begin{array}{r}16.704 \\
5\end{array}$ & 3.0 & 0.7938 & 3.3 & 0.0962 & 1.4 & 0.41 & 591.9 & 7.8 & 593.3 & 15.0 & 598.7 & 65.7 & 591.9 & 7.8 & 98.9 \\
\hline MO-52 & 26 & 11044 & 0.9 & $\begin{array}{r}13.149 \\
7\end{array}$ & 2.9 & 1.9390 & 3.5 & 0.1849 & 1.9 & 0.54 & 1093.8 & 18.9 & 1094.7 & 23.2 & 1096.3 & 58.2 & 1096.3 & 58.2 & 99.8 \\
\hline MO-53 & 108 & 99124 & 1.1 & $\begin{array}{r}13.664 \\
7 \\
\end{array}$ & 1.6 & 1.8038 & 1.8 & 0.1788 & 0.8 & 0.45 & 1060.2 & 7.9 & 1046.8 & 11.7 & 1019.0 & 32.2 & 1019.0 & 32.2 & 104.0 \\
\hline MO-54 & 481 & $\begin{array}{r}36677 \\
9\end{array}$ & 2.2 & $\begin{array}{r}12.781 \\
4\end{array}$ & 0.5 & 2.1423 & 2.6 & 0.1986 & 2.5 & 0.98 & 1167.7 & 27.0 & 1162.6 & 17.9 & 1152.9 & 10.8 & 1152.9 & 10.8 & 101.3 \\
\hline MO-56 & 471 & $\begin{array}{r}82363 \\
5\end{array}$ & 2.5 & $\begin{array}{r}12.256 \\
4\end{array}$ & 0.4 & 2.3576 & 1.8 & 0.2096 & 1.7 & 0.98 & 1226.5 & 19.4 & 1229.9 & 12.7 & 1235.7 & 7.3 & 1235.7 & 7.3 & 99.3 \\
\hline MO-57 & 352 & $\begin{array}{r}35629 \\
2 \\
\end{array}$ & 2.9 & $\begin{array}{r}13.664 \\
5 \\
\end{array}$ & 0.6 & 1.7490 & 1.1 & 0.1733 & 0.9 & 0.86 & 1030.5 & 8.9 & 1026.8 & 7.0 & 1019.0 & 11.3 & 1019.0 & 11.3 & 101.1 \\
\hline MO-58 & 427 & 92615 & 0.6 & $\begin{array}{r}17.900 \\
7 \\
\end{array}$ & 1.2 & 0.5651 & 1.3 & 0.0734 & 0.6 & 0.48 & 456.4 & 2.8 & 454.9 & 4.9 & 446.9 & 26.1 & 456.4 & 2.8 & 102.1 \\
\hline MO-59 & 57 & 26832 & 1.6 & $\begin{array}{r}13.652 \\
1\end{array}$ & 3.1 & 1.7500 & 3.3 & 0.1733 & 1.1 & 0.33 & 1030.1 & 10.2 & 1027.2 & 21.2 & 1020.8 & 62.7 & 1020.8 & 62.7 & 100.9 \\
\hline MO-60 & 142 & 11256 & 0.7 & $\begin{array}{r}17.504 \\
9\end{array}$ & 4.4 & 0.5699 & 4.8 & 0.0724 & 1.9 & 0.40 & 450.3 & 8.4 & 457.9 & 17.7 & 496.4 & 96.7 & 450.3 & 8.4 & 90.7 \\
\hline MO-61 & 462 & $\begin{array}{r}13639 \\
5\end{array}$ & 2.9 & $\begin{array}{r}18.208 \\
0\end{array}$ & 2.1 & 0.4551 & 2.7 & 0.0601 & 1.7 & 0.62 & 376.3 & 6.3 & 380.9 & 8.7 & 409.0 & 47.8 & 376.3 & 6.3 & NA \\
\hline MO-62 & 246 & $\begin{array}{r}29387 \\
6\end{array}$ & 0.7 & $\begin{array}{r}11.843 \\
9\end{array}$ & 0.7 & 2.3493 & 1.4 & 0.2018 & 1.2 & 0.86 & 1185.0 & 12.6 & 1227.4 & 9.6 & 1302.5 & 13.2 & 1302.5 & 13.2 & 91.0 \\
\hline
\end{tabular}




\begin{tabular}{|c|c|c|c|c|c|c|c|c|c|c|c|c|c|c|c|c|c|c|c|}
\hline Analysis & U & $206 \mathrm{~Pb}$ & $\begin{array}{c}\mathrm{U} / \mathrm{T} \\
\mathrm{h}\end{array}$ & $206 \mathrm{~Pb}^{*}$ & \pm & $207 \mathrm{~Pb}^{*}$ & \pm & $\underset{*}{206 \mathrm{~Pb}}$ & \pm & $\begin{array}{c}\text { erro } \\
\mathrm{r}\end{array}$ & $\underset{*}{206 \mathrm{~Pb}}$ & \pm & $\underset{*}{207 \mathrm{~Pb}}$ & \pm & $\underset{*}{206 \mathrm{~Pb}}$ & \pm & $\begin{array}{l}\text { Best } \\
\text { age }\end{array}$ & \pm & Conc \\
\hline & $\begin{array}{c}\text { (ppm } \\
\text { ) }\end{array}$ & $204 \mathrm{~Pb}$ & & $207 \mathrm{~Pb}^{*}$ & $(\%)$ & $235 \mathrm{U}^{*}$ & $(\%)$ & $238 \mathrm{U}$ & (\%) & corr. & $238 \mathrm{U}^{*}$ & (Ma) & $235 \mathrm{U}$ & (Ma) & $\underset{*}{207 \mathrm{~Pb}}$ & (Ma) & (Ma) & (Ma) & (\%) \\
\hline MO-63 & 189 & 52581 & 1.3 & $\begin{array}{r}18.184 \\
5 \\
\end{array}$ & 2.9 & 0.5014 & 3.2 & 0.0661 & 1.4 & 0.45 & 412.8 & 5.7 & 412.7 & 10.8 & 411.9 & 64.1 & 412.8 & 5.7 & 100.2 \\
\hline MO-64 & 28 & 8635 & 1.7 & $\begin{array}{r}13.057 \\
3 \\
\end{array}$ & 7.0 & 1.8385 & 7.3 & 0.1741 & 2.0 & 0.28 & 1034.7 & 19.2 & 1059.3 & 48.0 & 1110.4 & 140.1 & 1110.4 & $\begin{array}{r}140 . \\
1 \\
\end{array}$ & 93.2 \\
\hline MO-65 & 76 & 36602 & 0.9 & $\begin{array}{r}12.948 \\
6 \\
\end{array}$ & 1.4 & 2.0381 & 1.8 & 0.1914 & 1.2 & 0.65 & 1129.0 & 12.2 & 1128.3 & 12.4 & 1127.1 & 27.7 & 1127.1 & 27.7 & 100.2 \\
\hline MO-66 & 398 & 48627 & 1.3 & $\begin{array}{r}18.994 \\
4 \\
\end{array}$ & 1.4 & 0.3382 & 2.1 & 0.0466 & 1.5 & 0.72 & 293.6 & 4.2 & 295.8 & 5.3 & 313.6 & 32.7 & 293.6 & 4.2 & NA \\
\hline MO-67 & 123 & 55969 & 1.3 & $\begin{array}{r}18.629 \\
0\end{array}$ & 3.4 & 0.5179 & 3.6 & 0.0700 & 1.3 & 0.35 & 436.0 & 5.3 & 423.8 & 12.4 & 357.6 & 75.7 & 436.0 & 5.3 & 121.9 \\
\hline MO-68 & 77 & 25055 & 1.0 & $\begin{array}{r}16.931 \\
8 \\
\end{array}$ & 7.1 & 0.7479 & 7.2 & 0.0918 & 1.1 & 0.16 & 566.4 & 6.2 & 567.0 & 31.3 & 569.3 & 155.1 & 566.4 & 6.2 & 99.5 \\
\hline MO-69 & 412 & $\begin{array}{r}17402 \\
0 \\
\end{array}$ & 0.8 & $\begin{array}{r}18.895 \\
9 \\
\end{array}$ & 2.0 & 0.4297 & 2.2 & 0.0589 & 0.9 & 0.40 & 368.8 & 3.2 & 362.9 & 6.7 & 325.5 & 46.0 & 368.8 & 3.2 & NA \\
\hline MO- 70 & 35 & 27135 & 0.8 & 9.0702 & 1.4 & 5.0863 & 1.8 & 0.3346 & 1.0 & 0.58 & 1860.6 & 16.5 & 1833.8 & 14.9 & 1803.5 & 26.1 & 1803.5 & 26.1 & 103.2 \\
\hline MO- 71 & 215 & 50286 & 0.9 & $\begin{array}{r}18.067 \\
2 \\
\end{array}$ & 2.4 & 0.5303 & 3.0 & 0.0695 & 1.8 & 0.59 & 433.1 & 7.5 & 432.0 & 10.6 & 426.3 & 53.8 & 433.1 & 7.5 & 101.6 \\
\hline MO- 72 & 136 & $\begin{array}{r}14115 \\
3 \\
\end{array}$ & 1.6 & 7.7238 & 0.4 & 7.0636 & 1.0 & 0.3957 & 0.8 & 0.89 & 2149.2 & 15.5 & 2119.5 & 8.5 & 2090.8 & 7.8 & 2090.8 & 7.8 & 102.8 \\
\hline MO- 73 & 58 & 45437 & 2.1 & $\begin{array}{r}14.108 \\
4 \\
\end{array}$ & 4.8 & 1.5359 & 4.9 & 0.1572 & 1.2 & 0.23 & 941.0 & 10.1 & 944.9 & 30.4 & 954.0 & 98.4 & 954.0 & 98.4 & 98.6 \\
\hline MO- 74 & 101 & 10779 & 1.1 & $\begin{array}{r}14.020 \\
1 \\
\end{array}$ & 2.0 & 1.5087 & 2.6 & 0.1534 & 1.6 & 0.63 & 920.1 & 14.1 & 933.9 & 15.8 & 966.8 & 40.8 & 966.8 & 40.8 & 95.2 \\
\hline MO- 75 & 128 & 56308 & 5.2 & $\begin{array}{r}13.011 \\
2 \\
\end{array}$ & 1.3 & 2.0177 & 3.0 & 0.1904 & 2.7 & 0.90 & 1123.5 & 27.9 & 1121.5 & 20.5 & 1117.5 & 26.8 & 1117.5 & 26.8 & 100.5 \\
\hline MO- 76 & 261 & 47017 & 14.3 & $\begin{array}{r}18.267 \\
4 \\
\end{array}$ & 1.7 & 0.4764 & 4.6 & 0.0631 & 4.3 & 0.93 & 394.5 & 16.3 & 395.6 & 15.0 & 401.7 & 38.4 & 394.5 & 16.3 & NA \\
\hline MO- 77 & 698 & $\begin{array}{r}26448 \\
9 \\
\end{array}$ & 1.5 & $\begin{array}{r}12.712 \\
5 \\
\end{array}$ & 0.2 & 2.1271 & 0.8 & 0.1961 & 0.7 & 0.96 & 1154.4 & 7.8 & 1157.6 & 5.3 & 1163.6 & 4.3 & 1163.6 & 4.3 & 99.2 \\
\hline MO- 78 & 305 & 47819 & 1.1 & $\begin{array}{r}18.583 \\
0 \\
\end{array}$ & 4.2 & 0.4067 & 4.9 & 0.0548 & 2.5 & 0.51 & 344.0 & 8.4 & 346.5 & 14.5 & 363.2 & 95.5 & 344.0 & 8.4 & NA \\
\hline MO- 79 & 588 & 87160 & 0.7 & $\begin{array}{r}18.101 \\
8 \\
\end{array}$ & 3.0 & 0.4466 & 3.6 & 0.0586 & 2.0 & 0.56 & 367.3 & 7.1 & 374.9 & 11.2 & 422.1 & 66.6 & 367.3 & 7.1 & NA \\
\hline MO- 80 & 333 & 77169 & 1.2 & $\begin{array}{r}18.359 \\
4 \\
\end{array}$ & 3.0 & 0.5036 & 3.3 & 0.0671 & 1.2 & 0.36 & 418.4 & 4.7 & 414.1 & 11.1 & 390.4 & 68.3 & 418.4 & 4.7 & 107.2 \\
\hline MO- 81 & 148 & $\begin{array}{r}36920 \\
0 \\
\end{array}$ & 1.3 & $\begin{array}{r}13.273 \\
2 \\
\end{array}$ & 0.6 & 1.9278 & 1.3 & 0.1856 & 1.2 & 0.89 & 1097.4 & 11.7 & 1090.8 & 8.7 & 1077.6 & 12.1 & 1077.6 & 12.1 & 101.8 \\
\hline MO- 82 & 49 & 36489 & 2.0 & $\begin{array}{r}13.480 \\
7 \\
\end{array}$ & 3.4 & 1.8539 & 3.9 & 0.1813 & 1.7 & 0.44 & 1073.8 & 16.9 & 1064.8 & 25.4 & 1046.4 & 69.6 & 1046.4 & 69.6 & 102.6 \\
\hline MO- 83 & 247 & $\begin{array}{r}11072 \\
1 \\
\end{array}$ & 2.9 & $\begin{array}{r}12.912 \\
6 \\
\end{array}$ & 0.7 & 1.9936 & 1.7 & 0.1867 & 1.6 & 0.92 & 1103.5 & 16.1 & 1113.3 & 11.7 & 1132.6 & 13.8 & 1132.6 & 13.8 & 97.4 \\
\hline MO- 84 & 78 & 45570 & 0.6 & $\begin{array}{r}11.714 \\
2 \\
\end{array}$ & 1.8 & 2.6711 & 2.2 & 0.2269 & 1.2 & 0.54 & 1318.4 & 13.9 & 1320.5 & 16.0 & 1323.9 & 35.2 & 1323.9 & 35.2 & 99.6 \\
\hline MO- 85 & 100 & $\begin{array}{r}10212 \\
9 \\
\end{array}$ & 0.8 & 9.8340 & 0.5 & 4.1771 & 0.9 & 0.2979 & 0.8 & 0.86 & 1681.0 & 11.7 & 1669.5 & 7.5 & 1655.1 & 8.6 & 1655.1 & 8.6 & 101.6 \\
\hline MO- 86 & 164 & 18194 & 2.5 & $\begin{array}{r}12.612 \\
6 \\
\end{array}$ & 1.1 & 2.1248 & 4.9 & 0.1944 & 4.8 & 0.98 & 1145.0 & 50.0 & 1156.9 & 33.7 & 1179.3 & 21.3 & 1179.3 & 21.3 & 97.1 \\
\hline MO- 88 & 138 & 17367 & 1.7 & $\begin{array}{r}18.104 \\
3 \\
\end{array}$ & 4.1 & 0.5155 & 4.6 & 0.0677 & 2.0 & 0.44 & 422.2 & 8.3 & 422.1 & 15.9 & 421.7 & 92.4 & 422.2 & 8.3 & 100.1 \\
\hline MO- 89 & 505 & 63870 & 11.3 & $\begin{array}{r}17.090 \\
1 \\
\end{array}$ & 1.9 & 0.5687 & 3.4 & 0.0705 & 2.8 & 0.83 & 439.1 & 11.9 & 457.2 & 12.4 & 549.1 & 40.6 & 439.1 & 11.9 & 80.0 \\
\hline MO- 90 & 598 & 97956 & 3.7 & $\begin{array}{r}18.438 \\
7 \\
\end{array}$ & 1.2 & 0.4713 & 2.0 & 0.0630 & 1.6 & 0.80 & 394.0 & 6.1 & 392.1 & 6.5 & 380.8 & 27.1 & 394.0 & 6.1 & NA \\
\hline MO- 92 & 146 & $\begin{array}{r}14246 \\
2 \\
\end{array}$ & 1.9 & $\begin{array}{r}11.723 \\
9 \\
\end{array}$ & 0.7 & 2.7131 & 1.2 & 0.2307 & 0.9 & 0.79 & 1338.1 & 11.0 & 1332.1 & 8.6 & 1322.3 & 13.7 & 1322.3 & 13.7 & 101.2 \\
\hline MO- 93 & 167 & 52853 & 2.3 & $\begin{array}{r}18.009 \\
5\end{array}$ & 2.9 & 0.5230 & 3.1 & 0.0683 & 0.9 & 0.31 & 426.0 & 3.9 & 427.2 & 10.7 & 433.5 & 64.8 & 426.0 & 3.9 & 98.3 \\
\hline MO- 95 & 256 & $\begin{array}{r}22334 \\
2 \\
\end{array}$ & 2.5 & $\begin{array}{r}12.951 \\
5 \\
\end{array}$ & 1.2 & 2.0403 & 3.3 & 0.1917 & 3.0 & 0.93 & 1130.3 & 31.5 & 1129.1 & 22.2 & 1126.6 & 23.1 & 1126.6 & 23.1 & 100.3 \\
\hline MO- 91 & 133 & 30733 & 1.7 & $\begin{array}{r}18.526 \\
1 \\
\end{array}$ & 5.0 & 0.4513 & 5.6 & 0.0606 & 2.5 & 0.45 & 379.5 & 9.2 & 378.2 & 17.8 & 370.1 & 113.6 & 379.5 & 9.2 & NA \\
\hline MO- 97 & 189 & $\begin{array}{r}10472 \\
2 \\
\end{array}$ & 2.4 & $\begin{array}{r}11.829 \\
5 \\
\end{array}$ & 1.0 & 2.5087 & 1.7 & 0.2152 & 1.3 & 0.80 & 1256.6 & 15.4 & 1274.6 & 12.2 & 1304.9 & 19.4 & 1304.9 & 19.4 & 96.3 \\
\hline MO- 98 & 217 & 69956 & 2.4 & $\begin{array}{r}12.839 \\
9 \\
\end{array}$ & 0.4 & 1.9318 & 1.7 & 0.1799 & 1.7 & 0.98 & 1066.4 & 16.4 & 1092.2 & 11.5 & 1143.9 & 7.5 & 1143.9 & 7.5 & 93.2 \\
\hline MO- 99 & 172 & $\begin{array}{r}12778 \\
6 \\
\end{array}$ & 2.6 & $\begin{array}{r}13.023 \\
9 \\
\end{array}$ & 1.2 & 2.0452 & 2.6 & 0.1932 & 2.3 & 0.88 & 1138.6 & 24.1 & 1130.7 & 17.8 & 1115.5 & 24.5 & 1115.5 & 24.5 & 102.1 \\
\hline MO- 100 & 442 & $\begin{array}{r}14428 \\
9 \\
\end{array}$ & 1.2 & $\begin{array}{r}18.171 \\
1 \\
\end{array}$ & 1.4 & 0.5142 & 1.7 & 0.0678 & 1.0 & 0.61 & 422.7 & 4.2 & 421.3 & 5.9 & 413.5 & 30.4 & 422.7 & 4.2 & 102.2 \\
\hline
\end{tabular}

\begin{tabular}{|c|c|c|c|c|c|c|c|c|c|c|c|c|c|c|c|c|c|c|c|}
\hline Analysis & U & $206 \mathrm{~Pb}$ & $\begin{array}{c}\mathrm{U} / \mathrm{T} \\
\mathrm{h}\end{array}$ & $206 \mathrm{~Pb}^{*}$ & \pm & $207 \mathrm{~Pb}^{*}$ & \pm & $\underset{*}{206 \mathrm{~Pb}}$ & \pm & $\begin{array}{c}\text { erro } \\
\mathrm{r}\end{array}$ & $\underset{*}{206 \mathrm{~Pb}}$ & \pm & $\underset{*}{207 \mathrm{~Pb}}$ & \pm & $\underset{*}{206 \mathrm{~Pb}}$ & \pm & $\begin{array}{l}\text { Best } \\
\text { age }\end{array}$ & \pm & Conc \\
\hline & (ppm & $204 \mathrm{~Pb}$ & & $207 \mathrm{~Pb}^{*}$ & $(\%)$ & $235 \mathrm{U}^{*}$ & (\%) & $238 \mathrm{U}$ & (\%) & corr. & $238 \mathrm{U}^{*}$ & (Ma) & $235 \mathrm{U}$ & (Ma) & $\underset{*}{207 \mathrm{~Pb}}$ & (Ma) & (Ma) & (Ma) & (\%) \\
\hline P1004-68 & 473 & $\begin{array}{r}11618 \\
8 \\
\end{array}$ & 0.8 & $\begin{array}{r}18.257 \\
0\end{array}$ & 1.1 & 0.4498 & 1.4 & 0.0596 & 0.9 & 0.63 & 373.0 & 3.2 & 377.1 & 4.5 & 403.0 & 24.7 & 373.0 & 3.2 & NA \\
\hline
\end{tabular}




\begin{tabular}{|c|c|c|c|c|c|c|c|c|c|c|c|c|c|c|c|c|c|c|c|}
\hline Analysis & $\mathrm{U}$ & $206 \mathrm{~Pb}$ & $\begin{array}{c}\mathrm{U} / \mathrm{T} \\
\mathrm{h}\end{array}$ & $206 \mathrm{~Pb}^{*}$ & \pm & 207 $\mathrm{Pb}^{*}$ & \pm & $\underset{*}{206 \mathrm{~Pb}}$ & \pm & $\begin{array}{c}\text { erro } \\
\mathrm{r}\end{array}$ & $\underset{*}{206 \mathrm{~Pb}}$ & \pm & $\underset{*}{207 \mathrm{~Pb}}$ & \pm & $\underset{*}{206 \mathrm{~Pb}}$ & \pm & $\begin{array}{l}\text { Best } \\
\text { age }\end{array}$ & \pm & Conc \\
\hline & $\begin{array}{c}(\mathrm{ppm} \\
)\end{array}$ & $204 \mathrm{~Pb}$ & & $207 \mathrm{~Pb}^{*}$ & (\%) & $235 \mathrm{U}^{*}$ & (\%) & $238 \mathrm{U}$ & (\%) & corr. & $238 \mathrm{U}^{*}$ & (Ma) & $235 \mathrm{U}$ & (Ma) & $\underset{*}{207 \mathrm{~Pb}}$ & (Ma) & (Ma) & (Ma) & $(\%)$ \\
\hline P1004-8 & 1006 & $\begin{array}{r}19131 \\
0 \\
\end{array}$ & 3.5 & $\begin{array}{r}18.229 \\
8 \\
\end{array}$ & 0.5 & 0.4550 & 1.1 & 0.0602 & 1.0 & 0.87 & 376.6 & 3.5 & 380.7 & 3.5 & 406.3 & 12.2 & 376.6 & 3.5 & NA \\
\hline P1004-51 & 58 & 12599 & 1.0 & $\begin{array}{r}18.204 \\
6 \\
\end{array}$ & 8.3 & 0.4924 & 8.4 & 0.0650 & 1.6 & 0.19 & 406.0 & 6.4 & 406.5 & 28.3 & 409.4 & 185.7 & 406.0 & 6.4 & 99.2 \\
\hline P1004-33 & 90 & 20665 & 0.4 & $\begin{array}{r}18.914 \\
6 \\
\end{array}$ & 4.1 & 0.4791 & 4.3 & 0.0657 & 1.2 & 0.28 & 410.4 & 4.7 & 397.5 & 14.1 & 323.2 & 93.8 & 410.4 & 4.7 & 127.0 \\
\hline P1004-89 & 155 & 17115 & 5.6 & $\begin{array}{r}17.176 \\
9\end{array}$ & 6.3 & 0.5291 & 6.7 & 0.0659 & 2.2 & 0.34 & 411.5 & 8.9 & 431.2 & 23.4 & 538.0 & 137.3 & 411.5 & 8.9 & 76.5 \\
\hline P1004-55 & 146 & 17191 & 2.2 & $\begin{array}{r}17.845 \\
4 \\
\end{array}$ & 5.0 & 0.5157 & 5.4 & 0.0667 & 2.0 & 0.38 & 416.5 & 8.2 & 422.3 & 18.5 & 453.9 & 110.1 & 416.5 & 8.2 & 91.8 \\
\hline P1004-74 & 188 & 66418 & 0.9 & $\begin{array}{r}18.198 \\
7 \\
\end{array}$ & 3.4 & 0.5164 & 3.7 & 0.0682 & 1.3 & 0.36 & 425.0 & 5.5 & 422.7 & 12.8 & 410.1 & 77.2 & 425.0 & 5.5 & 103.6 \\
\hline P1004-27 & 92 & 28832 & 0.9 & $\begin{array}{r}18.161 \\
6 \\
\end{array}$ & 7.8 & 0.5730 & 7.9 & 0.0755 & 1.2 & 0.15 & 469.0 & 5.4 & 459.9 & 29.1 & 414.7 & 173.7 & 469.0 & 5.4 & 113.1 \\
\hline P1004-53 & 75 & 30102 & 1.1 & $\begin{array}{r}16.424 \\
4 \\
\end{array}$ & 4.5 & 0.7418 & 4.8 & 0.0884 & 1.4 & 0.30 & 545.9 & 7.4 & 563.5 & 20.6 & 635.2 & 97.8 & 545.9 & 7.4 & 85.9 \\
\hline P1004-48 & 78 & 14239 & 1.1 & $\begin{array}{r}18.402 \\
6 \\
\end{array}$ & 7.6 & 0.6633 & 7.7 & 0.0885 & 1.4 & 0.18 & 546.9 & 7.2 & 516.7 & 31.3 & 385.2 & 170.8 & 546.9 & 7.2 & 142.0 \\
\hline P1004-79 & 33 & 9872 & 0.9 & $\begin{array}{r}16.948 \\
0 \\
\end{array}$ & $\begin{array}{r}10 . \\
5 \\
\end{array}$ & 0.7346 & $\begin{array}{r}10 . \\
9 \\
\end{array}$ & 0.0903 & 2.8 & 0.26 & 557.3 & 15.0 & 559.2 & 46.8 & 567.3 & 229.0 & 557.3 & 15.0 & 98.2 \\
\hline P1004-28 & 63 & 19641 & 1.0 & $\begin{array}{r}17.428 \\
8 \\
\end{array}$ & 6.7 & 0.7162 & 7.0 & 0.0905 & 2.1 & 0.30 & 558.7 & 11.1 & 548.4 & 29.8 & 506.0 & 147.8 & 558.7 & 11.1 & 110.4 \\
\hline P1004-4 & 103 & 31878 & 0.8 & $\begin{array}{r}16.744 \\
3 \\
\end{array}$ & 4.2 & 0.7685 & 4.5 & 0.0933 & 1.5 & 0.33 & 575.2 & 8.2 & 578.9 & 19.7 & 593.5 & 91.4 & 575.2 & 8.2 & 96.9 \\
\hline P1004-23 & 65 & 38751 & 0.8 & $\begin{array}{r}17.065 \\
5 \\
\end{array}$ & 3.4 & 0.7598 & 3.9 & 0.0940 & 1.9 & 0.48 & 579.4 & 10.5 & 573.9 & 17.2 & 552.2 & 75.0 & 579.4 & 10.5 & 104.9 \\
\hline P1004-54 & 168 & 65018 & 1.0 & $\begin{array}{r}16.247 \\
0 \\
\end{array}$ & 1.3 & 0.8128 & 1.8 & 0.0958 & 1.3 & 0.70 & 589.6 & 7.1 & 604.0 & 8.2 & 658.5 & 27.8 & 589.6 & 7.1 & 89.5 \\
\hline P1004-47 & 258 & 66275 & 3.1 & $\begin{array}{r}16.495 \\
9 \\
\end{array}$ & 1.0 & 0.8329 & 1.4 & 0.0996 & 1.0 & 0.68 & 612.3 & 5.6 & 615.2 & 6.5 & 625.8 & 22.3 & 612.3 & 5.6 & 97.8 \\
\hline P1004-88 & 75 & 31688 & 1.0 & $\begin{array}{r}16.409 \\
1 \\
\end{array}$ & 5.1 & 0.8466 & 5.2 & 0.1008 & 1.0 & 0.20 & 618.8 & 6.1 & 622.8 & 24.3 & 637.2 & 110.1 & 618.8 & 6.1 & 97.1 \\
\hline P1004-17 & 98 & 4912 & 0.9 & $\begin{array}{r}15.602 \\
7 \\
\end{array}$ & 8.0 & 0.8909 & 8.2 & 0.1008 & 1.4 & 0.17 & 619.2 & 8.1 & 646.9 & 39.0 & 744.6 & 170.1 & 619.2 & 8.1 & 83.2 \\
\hline P1004-42 & 121 & 33300 & 0.4 & $\begin{array}{r}16.398 \\
1 \\
\end{array}$ & 2.1 & 0.8504 & 2.3 & 0.1011 & 0.9 & 0.39 & 621.1 & 5.2 & 624.9 & 10.6 & 638.6 & 45.1 & 621.1 & 5.2 & 97.3 \\
\hline P1004-64 & 187 & $\begin{array}{r}11037 \\
9 \\
\end{array}$ & 1.8 & $\begin{array}{r}16.524 \\
2 \\
\end{array}$ & 1.4 & 0.8449 & 2.5 & 0.1013 & 2.1 & 0.83 & 621.7 & 12.2 & 621.8 & 11.6 & 622.1 & 30.1 & 621.7 & 12.2 & 99.9 \\
\hline P1004-36 & 84 & 41785 & 1.2 & $\begin{array}{r}16.249 \\
0 \\
\end{array}$ & 5.3 & 0.8834 & 5.5 & 0.1041 & 1.4 & 0.26 & 638.4 & 8.7 & 642.8 & 26.3 & 658.2 & 114.4 & 638.4 & 8.7 & 97.0 \\
\hline P1004-45 & 214 & $\begin{array}{r}17671 \\
7 \\
\end{array}$ & 1.2 & $\begin{array}{r}16.000 \\
0 \\
\end{array}$ & 1.4 & 0.9132 & 7.1 & 0.1060 & 6.9 & 0.98 & 649.3 & 42.8 & 658.7 & 34.3 & 691.2 & 29.8 & 649.3 & 42.8 & 93.9 \\
\hline P1004-46 & 49 & 17192 & 3.2 & $\begin{array}{r}14.731 \\
0 \\
\end{array}$ & 2.5 & 1.1348 & 3.0 & 0.1212 & 1.7 & 0.58 & 737.7 & 12.2 & 770.0 & 16.4 & 865.0 & 51.3 & 737.7 & 12.2 & 85.3 \\
\hline P1004-52 & 57 & 15856 & 1.3 & $\begin{array}{r}14.306 \\
8 \\
\end{array}$ & 2.7 & 1.4140 & 3.6 & 0.1467 & 2.4 & 0.66 & 882.5 & 19.5 & 894.8 & 21.3 & 925.3 & 55.1 & 925.3 & 55.1 & 95.4 \\
\hline P1004-67 & 126 & $\begin{array}{r}12455 \\
0 \\
\end{array}$ & 2.0 & $\begin{array}{r}14.241 \\
8 \\
\end{array}$ & 1.2 & 1.5483 & 1.5 & 0.1599 & 0.9 & 0.61 & 956.4 & 8.0 & 949.8 & 9.1 & 934.7 & 24.1 & 934.7 & 24.1 & 102.3 \\
\hline P1004-91 & 72 & $\begin{array}{r}11055 \\
1 \\
\end{array}$ & 1.5 & $\begin{array}{r}14.093 \\
4 \\
\end{array}$ & 2.0 & 1.6053 & 2.5 & 0.1641 & 1.6 & 0.62 & 979.4 & 14.4 & 972.3 & 15.9 & 956.1 & 40.6 & 956.1 & 40.6 & 102.4 \\
\hline P1004-56 & 24 & 15362 & 1.0 & $\begin{array}{r}14.007 \\
5 \\
\end{array}$ & 4.8 & 1.6706 & 5.1 & 0.1697 & 1.7 & 0.34 & 1010.6 & 16.3 & 997.4 & 32.3 & 968.6 & 97.6 & 968.6 & 97.6 & 104.3 \\
\hline P1004-66 & 61 & 31546 & 1.8 & $\begin{array}{r}13.963 \\
0 \\
\end{array}$ & 1.7 & 1.5890 & 2.2 & 0.1609 & 1.3 & 0.61 & 961.9 & 11.7 & 965.9 & 13.4 & 975.1 & 34.9 & 975.1 & 34.9 & 98.6 \\
\hline P1004-73 & 200 & 94844 & 4.0 & $\begin{array}{r}13.867 \\
0 \\
\end{array}$ & 0.8 & 1.5947 & 1.3 & 0.1604 & 1.0 & 0.79 & 958.9 & 9.2 & 968.2 & 8.1 & 989.1 & 16.2 & 989.1 & 16.2 & 96.9 \\
\hline P1004-1 & 166 & 70878 & 2.0 & $\begin{array}{r}13.700 \\
3 \\
\end{array}$ & 0.9 & 1.7571 & 2.0 & 0.1746 & 1.8 & 0.90 & 1037.3 & 17.4 & 1029.8 & 13.0 & 1013.7 & 17.3 & 1013.7 & 17.3 & 102.3 \\
\hline P1004-98 & 109 & 61433 & 3.0 & $\begin{array}{r}13.682 \\
0 \\
\end{array}$ & 1.3 & 1.7212 & 1.6 & 0.1708 & 1.0 & 0.58 & 1016.5 & 9.0 & 1016.5 & 10.6 & 1016.4 & 27.3 & 1016.4 & 27.3 & 100.0 \\
\hline P1004-43 & 436 & $\begin{array}{r}27182 \\
3 \\
\end{array}$ & 3.7 & $\begin{array}{r}13.663 \\
2 \\
\end{array}$ & 0.3 & 1.7717 & 1.3 & 0.1756 & 1.3 & 0.97 & 1042.7 & 12.5 & 1035.1 & 8.7 & 1019.2 & 7.0 & 1019.2 & 7.0 & 102.3 \\
\hline P1004-22 & 113 & 85597 & 1.6 & $\begin{array}{r}13.627 \\
2 \\
\end{array}$ & 1.9 & 1.7805 & 2.3 & 0.1760 & 1.4 & 0.61 & 1045.0 & 13.9 & 1038.4 & 15.3 & 1024.5 & 37.5 & 1024.5 & 37.5 & 102.0 \\
\hline P1004-72 & 155 & $\begin{array}{r}13262 \\
6 \\
\end{array}$ & 1.9 & $\begin{array}{r}13.614 \\
1 \\
\end{array}$ & 0.7 & 1.7308 & 1.6 & 0.1709 & 1.4 & 0.89 & 1017.1 & 13.3 & 1020.1 & 10.2 & 1026.5 & 14.8 & 1026.5 & 14.8 & 99.1 \\
\hline P1004-76 & 138 & 96679 & 1.9 & $\begin{array}{r}13.574 \\
1 \\
\end{array}$ & 1.2 & 1.7887 & 2.1 & 0.1761 & 1.7 & 0.81 & 1045.6 & 16.4 & 1041.4 & 13.7 & 1032.4 & 25.2 & 1032.4 & 25.2 & 101.3 \\
\hline P1004-58 & 84 & 39911 & 2.3 & $\begin{array}{r}13.565 \\
5 \\
\end{array}$ & 2.3 & 1.7571 & 2.8 & 0.1729 & 1.6 & 0.58 & 1027.9 & 15.5 & 1029.8 & 18.1 & 1033.7 & 45.8 & 1033.7 & 45.8 & 99.4 \\
\hline P1004-96 & 121 & 45285 & 1.8 & $\begin{array}{r}13.555 \\
8 \\
\end{array}$ & 1.3 & 1.7394 & 1.4 & 0.1710 & 0.7 & 0.47 & 1017.7 & 6.4 & 1023.2 & 9.3 & 1035.1 & 25.8 & 1035.1 & 25.8 & 98.3 \\
\hline P1004-70 & 108 & $\begin{array}{r}13637 \\
2 \\
\end{array}$ & 2.9 & $\begin{array}{r}13.523 \\
2 \\
\end{array}$ & 1.9 & 1.7779 & 2.1 & 0.1744 & 0.9 & 0.42 & 1036.2 & 8.5 & 1037.4 & 13.7 & 1040.0 & 38.5 & 1040.0 & 38.5 & 99.6 \\
\hline P1004-60 & 155 & $\begin{array}{r}13966 \\
8 \\
\end{array}$ & 2.8 & $\begin{array}{r}13.487 \\
9 \\
\end{array}$ & 1.4 & 1.7429 & 2.4 & 0.1705 & 1.9 & 0.81 & 1014.8 & 18.1 & 1024.5 & 15.4 & 1045.3 & 28.2 & 1045.3 & 28.2 & 97.1 \\
\hline P1004-21 & 113 & 65291 & 2.5 & $\begin{array}{r}13.429 \\
2 \\
\end{array}$ & 1.1 & 1.8171 & 1.3 & 0.1770 & 0.7 & 0.53 & 1050.5 & 6.7 & 1051.6 & 8.5 & 1054.1 & 22.0 & 1054.1 & 22.0 & 99.7 \\
\hline
\end{tabular}




\begin{tabular}{|c|c|c|c|c|c|c|c|c|c|c|c|c|c|c|c|c|c|c|c|}
\hline Analysis & $u$ & $206 \mathrm{~Pb}$ & $\begin{array}{c}\mathrm{U} / \mathrm{T} \\
\mathrm{h}\end{array}$ & $206 \mathrm{~Pb}^{*}$ & \pm & $207 \mathrm{~Pb}^{*}$ & \pm & $\underset{*}{206 \mathrm{~Pb}}$ & \pm & $\begin{array}{c}\text { erro } \\
\mathrm{r}\end{array}$ & $\underset{*}{206 \mathrm{~Pb}}$ & \pm & $\underset{*}{207 \mathrm{~Pb}}$ & \pm & $\underset{*}{206 \mathrm{~Pb}}$ & \pm & $\begin{array}{c}\text { Best } \\
\text { age }\end{array}$ & \pm & Conc \\
\hline & $\begin{array}{c}(\mathrm{ppm} \\
)\end{array}$ & $204 \mathrm{~Pb}$ & & $207 \mathrm{~Pb}^{*}$ & $(\%)$ & $235 \mathrm{U}^{*}$ & $(\%)$ & $238 \mathrm{U}$ & (\%) & corr. & $238 \mathrm{U}^{*}$ & (Ma) & $235 \mathrm{U}$ & (Ma) & $\underset{*}{207 \mathrm{~Pb}}$ & (Ma) & (Ma) & (Ma) & $(\%)$ \\
\hline P1004-80 & 133 & 62002 & 2.3 & $\begin{array}{r}13.410 \\
7 \\
\end{array}$ & 1.2 & 1.8369 & 1.6 & 0.1787 & 1.0 & 0.64 & 1059.6 & 9.9 & 1058.7 & 10.4 & 1056.9 & 24.5 & 1056.9 & 24.5 & 100.3 \\
\hline P1004-92 & 106 & 61122 & 3.1 & $\begin{array}{r}13.387 \\
9 \\
\end{array}$ & 1.6 & 1.8705 & 2.2 & 0.1816 & 1.6 & 0.71 & 1075.8 & 15.9 & 1070.7 & 14.9 & 1060.3 & 31.7 & 1060.3 & 31.7 & 101.5 \\
\hline P1004-59 & 72 & 50016 & 1.6 & $\begin{array}{r}13.369 \\
7 \\
\end{array}$ & 2.3 & 1.7717 & 2.9 & 0.1718 & 1.8 & 0.62 & 1022.0 & 16.7 & 1035.1 & 18.6 & 1063.0 & 45.4 & 1063.0 & 45.4 & 96.1 \\
\hline P1004-93 & 157 & $\begin{array}{r}11606 \\
9 \\
\end{array}$ & 2.6 & $\begin{array}{r}13.367 \\
8 \\
\end{array}$ & 0.9 & 1.8569 & 1.5 & 0.1800 & 1.1 & 0.77 & 1067.1 & 11.1 & 1065.9 & 9.7 & 1063.3 & 18.8 & 1063.3 & 18.8 & 100.4 \\
\hline P1004-9 & 63 & 34054 & 1.4 & $\begin{array}{r}13.355 \\
2\end{array}$ & 1.9 & 1.9149 & 2.1 & 0.1855 & 0.9 & 0.45 & 1096.8 & 9.4 & 1086.3 & 13.9 & 1065.2 & 37.6 & 1065.2 & 37.6 & 103.0 \\
\hline P1004-15 & 259 & $\begin{array}{r}17682 \\
0 \\
\end{array}$ & 3.2 & $\begin{array}{r}13.342 \\
1 \\
\end{array}$ & 0.5 & 1.8584 & 0.7 & 0.1798 & 0.5 & 0.74 & 1066.0 & 5.3 & 1066.4 & 4.8 & 1067.2 & 9.9 & 1067.2 & 9.9 & 99.9 \\
\hline P1004-41 & 142 & $\begin{array}{r}10114 \\
2 \\
\end{array}$ & 1.9 & $\begin{array}{r}13.325 \\
4 \\
\end{array}$ & 0.9 & 1.8456 & 1.1 & 0.1784 & 0.6 & 0.56 & 1058.0 & 5.8 & 1061.8 & 6.9 & 1069.7 & 17.5 & 1069.7 & 17.5 & 98.9 \\
\hline P1004-61 & 55 & 45768 & 2.2 & $\begin{array}{r}13.317 \\
1 \\
\end{array}$ & 3.9 & 1.9362 & 9.9 & 0.1870 & 9.1 & 0.92 & 1105.2 & 92.8 & 1093.7 & 66.5 & 1071.0 & 77.6 & 1071.0 & 77.6 & 103.2 \\
\hline P1004-49 & 76 & 47801 & 1.7 & $\begin{array}{r}13.276 \\
3 \\
\end{array}$ & 2.4 & 1.8284 & 2.5 & 0.1761 & 0.7 & 0.26 & 1045.4 & 6.4 & 1055.7 & 16.4 & 1077.1 & 48.3 & 1077.1 & 48.3 & 97.1 \\
\hline P1004-69 & 181 & $\begin{array}{r}17614 \\
0 \\
\end{array}$ & 2.3 & $\begin{array}{r}13.250 \\
8 \\
\end{array}$ & 0.7 & 1.8490 & 1.0 & 0.1777 & 0.7 & 0.70 & 1054.4 & 6.8 & 1063.1 & 6.6 & 1081.0 & 14.5 & 1081.0 & 14.5 & 97.5 \\
\hline $\begin{array}{l}\text { P1004- } \\
100 \\
\end{array}$ & 137 & 64342 & 2.6 & $\begin{array}{r}13.243 \\
2 \\
\end{array}$ & 2.0 & 1.8234 & 3.3 & 0.1751 & 2.6 & 0.80 & 1040.4 & 25.3 & 1053.9 & 21.7 & 1082.1 & 40.1 & 1082.1 & 40.1 & 96.1 \\
\hline P1004-81 & 145 & 82704 & 2.4 & $\begin{array}{r}13.177 \\
2 \\
\end{array}$ & 0.8 & 1.9320 & 1.4 & 0.1846 & 1.1 & 0.80 & 1092.3 & 10.8 & 1092.2 & 9.0 & 1092.1 & 16.3 & 1092.1 & 16.3 & 100.0 \\
\hline P1004-85 & 248 & $\begin{array}{r}20955 \\
6 \\
\end{array}$ & 6.5 & $\begin{array}{r}13.170 \\
8 \\
\end{array}$ & 1.7 & 1.7921 & 1.9 & 0.1712 & 0.8 & 0.43 & 1018.6 & 7.9 & 1042.6 & 12.5 & 1093.1 & 34.7 & 1093.1 & 34.7 & 93.2 \\
\hline P1004-16 & 426 & $\begin{array}{r}14923 \\
5 \\
\end{array}$ & 6.0 & $\begin{array}{r}13.145 \\
0 \\
\end{array}$ & 1.4 & 1.7970 & 1.8 & 0.1713 & 1.1 & 0.61 & 1019.4 & 10.5 & 1044.4 & 11.9 & 1097.0 & 28.8 & 1097.0 & 28.8 & 92.9 \\
\hline P1004-3 & 212 & 3869 & 1.8 & $\begin{array}{r}13.092 \\
6 \\
\end{array}$ & 1.2 & 1.9002 & 1.4 & 0.1804 & 0.8 & 0.53 & 1069.4 & 7.4 & 1081.2 & 9.5 & 1105.0 & 24.2 & 1105.0 & 24.2 & 96.8 \\
\hline P1004-87 & 286 & $\begin{array}{r}11161 \\
2 \\
\end{array}$ & 8.8 & $\begin{array}{r}13.058 \\
3 \\
\end{array}$ & 0.5 & 1.9270 & 1.8 & 0.1825 & 1.7 & 0.96 & 1080.6 & 17.0 & 1090.5 & 11.9 & 1110.2 & 10.4 & 1110.2 & 10.4 & 97.3 \\
\hline P1004-82 & 59 & 27880 & 1.9 & $\begin{array}{r}13.024 \\
8 \\
\end{array}$ & 1.1 & 1.9354 & 2.0 & 0.1828 & 1.7 & 0.84 & 1082.4 & 16.5 & 1093.4 & 13.2 & 1115.4 & 21.5 & 1115.4 & 21.5 & 97.0 \\
\hline P1004-63 & 47 & 31492 & 2.2 & $\begin{array}{r}12.965 \\
7 \\
\end{array}$ & 2.3 & 2.0789 & 2.7 & 0.1955 & 1.3 & 0.50 & 1151.1 & 14.1 & 1141.9 & 18.3 & 1124.5 & 46.2 & 1124.5 & 46.2 & 102.4 \\
\hline P1004-11 & 685 & $\begin{array}{r}54079 \\
9 \\
\end{array}$ & 4.1 & $\begin{array}{r}12.869 \\
5 \\
\end{array}$ & 0.4 & 2.0328 & 0.7 & 0.1897 & 0.5 & 0.76 & 1120.0 & 5.1 & 1126.5 & 4.5 & 1139.3 & 8.6 & 1139.3 & 8.6 & 98.3 \\
\hline P1004-40 & 133 & $\begin{array}{r}13191 \\
7 \\
\end{array}$ & 2.0 & $\begin{array}{r}12.755 \\
4 \\
\end{array}$ & 1.1 & 2.0924 & 1.8 & 0.1936 & 1.4 & 0.78 & 1140.7 & 14.7 & 1146.3 & 12.5 & 1157.0 & 22.8 & 1157.0 & 22.8 & 98.6 \\
\hline P1004-30 & 247 & $\begin{array}{r}14500 \\
3 \\
\end{array}$ & 1.3 & $\begin{array}{r}12.704 \\
2 \\
\end{array}$ & 0.7 & 2.1063 & 5.3 & 0.1941 & 5.3 & 0.99 & 1143.4 & 55.3 & 1150.9 & 36.6 & 1164.9 & 13.3 & 1164.9 & 13.3 & 98.2 \\
\hline P1004-75 & 29 & 18858 & 1.5 & $\begin{array}{r}12.677 \\
6 \\
\end{array}$ & 3.4 & 2.1453 & 3.8 & 0.1973 & 1.9 & 0.48 & 1160.5 & 19.7 & 1163.5 & 26.6 & 1169.1 & 66.7 & 1169.1 & 66.7 & 99.3 \\
\hline P1004-95 & 260 & $\begin{array}{r}11781 \\
5 \\
\end{array}$ & 2.9 & $\begin{array}{r}12.604 \\
7 \\
\end{array}$ & 0.3 & 2.1116 & 1.0 & 0.1930 & 1.0 & 0.95 & 1137.8 & 10.0 & 1152.6 & 6.9 & 1180.5 & 5.9 & 1180.5 & 5.9 & 96.4 \\
\hline P1004-34 & 46 & 26060 & 1.4 & $\begin{array}{r}12.573 \\
6 \\
\end{array}$ & 4.1 & 2.2043 & 4.6 & 0.2010 & 2.1 & 0.46 & 1180.8 & 22.8 & 1182.4 & 32.3 & 1185.4 & 81.1 & 1185.4 & 81.1 & 99.6 \\
\hline P1004-38 & 75 & 77397 & 2.9 & $\begin{array}{r}12.548 \\
4 \\
\end{array}$ & 1.4 & 2.2034 & 1.7 & 0.2005 & 1.0 & 0.59 & 1178.2 & 10.8 & 1182.1 & 11.9 & 1189.4 & 27.1 & 1189.4 & 27.1 & 99.1 \\
\hline P1004-97 & 77 & 9322 & 1.6 & $\begin{array}{r}12.323 \\
8 \\
\end{array}$ & 2.9 & 2.0118 & 3.1 & 0.1798 & 1.1 & 0.36 & 1066.0 & 10.7 & 1119.5 & 20.8 & 1224.9 & 56.4 & 1224.9 & 56.4 & 87.0 \\
\hline P1004-62 & 267 & $\begin{array}{r}19617 \\
2 \\
\end{array}$ & 0.8 & $\begin{array}{r}12.280 \\
8 \\
\end{array}$ & 0.8 & 2.3595 & 1.3 & 0.2102 & 1.0 & 0.79 & 1229.7 & 11.3 & 1230.4 & 9.2 & 1231.8 & 15.7 & 1231.8 & 15.7 & 99.8 \\
\hline P1004-50 & 372 & $\begin{array}{r}53439 \\
2 \\
\end{array}$ & 1.7 & $\begin{array}{r}12.234 \\
6 \\
\end{array}$ & 0.2 & 2.3500 & 0.9 & 0.2085 & 0.8 & 0.97 & 1221.0 & 9.3 & 1227.6 & 6.1 & 1239.2 & 4.2 & 1239.2 & 4.2 & 98.5 \\
\hline P1004-12 & 41 & 34337 & 4.2 & $\begin{array}{r}12.128 \\
7\end{array}$ & 2.1 & 2.1761 & 2.6 & 0.1914 & 1.6 & 0.60 & 1129.1 & 16.4 & 1173.4 & 18.4 & 1256.2 & 41.6 & 1256.2 & 41.6 & 89.9 \\
\hline P1004-35 & 80 & 84318 & 3.4 & $\begin{array}{r}12.095 \\
0 \\
\end{array}$ & 1.5 & 2.1647 & 3.8 & 0.1899 & 3.5 & 0.93 & 1120.8 & 36.4 & 1169.8 & 26.6 & 1261.6 & 28.4 & 1261.6 & 28.4 & 88.8 \\
\hline P1004-77 & 140 & $\begin{array}{r}16240 \\
0 \\
\end{array}$ & 3.1 & $\begin{array}{r}11.942 \\
9 \\
\end{array}$ & 1.9 & 2.5042 & 5.5 & 0.2169 & 5.1 & 0.94 & 1265.5 & 59.1 & 1273.3 & 39.7 & 1286.3 & 36.2 & 1286.3 & 36.2 & 98.4 \\
\hline P1004-14 & 59 & 29354 & 0.9 & $\begin{array}{r}11.890 \\
4 \\
\end{array}$ & 1.1 & 2.5433 & 4.5 & 0.2193 & 4.4 & 0.97 & 1278.3 & 50.4 & 1284.5 & 32.7 & 1294.9 & 21.2 & 1294.9 & 21.2 & 98.7 \\
\hline P1004-20 & 48 & 53269 & 0.9 & $\begin{array}{r}11.882 \\
0 \\
\end{array}$ & 2.7 & 2.5735 & 6.3 & 0.2218 & 5.6 & 0.90 & 1291.3 & 66.0 & 1293.1 & 45.7 & 1296.3 & 52.5 & 1296.3 & 52.5 & 99.6 \\
\hline P1004-2 & 36 & 11811 & 1.4 & $\begin{array}{r}11.810 \\
3 \\
\end{array}$ & 2.4 & 2.5712 & 3.8 & 0.2202 & 2.9 & 0.77 & 1283.1 & 34.2 & 1292.5 & 27.9 & 1308.0 & 47.4 & 1308.0 & 47.4 & 98.1 \\
\hline P1004-31 & 313 & $\begin{array}{r}13821 \\
4 \\
\end{array}$ & 1.1 & $\begin{array}{r}11.741 \\
1 \\
\end{array}$ & 0.4 & 2.4815 & 0.9 & 0.2113 & 0.8 & 0.88 & 1235.8 & 8.9 & 1266.7 & 6.6 & 1319.4 & 8.5 & 1319.4 & 8.5 & 93.7 \\
\hline P1004-32 & 78 & 50513 & 2.1 & $\begin{array}{r}11.681 \\
2 \\
\end{array}$ & 1.4 & 2.7180 & 2.7 & 0.2303 & 2.4 & 0.86 & 1335.9 & 28.4 & 1333.4 & 20.4 & 1329.3 & 27.3 & 1329.3 & 27.3 & 100.5 \\
\hline P1004-78 & 13 & 15683 & 0.5 & $\begin{array}{r}11.476 \\
8 \\
\end{array}$ & 8.0 & 2.4679 & 8.4 & 0.2054 & 2.5 & 0.30 & 1204.4 & 27.5 & 1262.7 & 60.7 & 1363.4 & 154.4 & 1363.4 & $\begin{array}{r}154 . \\
4 \\
\end{array}$ & 88.3 \\
\hline $\mathrm{P} 1004-5$ & 142 & 86223 & 1.2 & $\begin{array}{r}11.373 \\
4 \\
\end{array}$ & 1.0 & 2.9683 & 1.2 & 0.2448 & 0.7 & 0.59 & 1411.9 & 9.2 & 1399.5 & 9.3 & 1380.8 & 19.1 & 1380.8 & 19.1 & 102.2 \\
\hline P1004-37 & 55 & 36433 & 0.9 & $\begin{array}{r}11.307 \\
9 \\
\end{array}$ & 1.9 & 2.8674 & 2.7 & 0.2352 & 1.9 & 0.70 & 1361.5 & 23.0 & 1373.4 & 20.2 & 1391.9 & 37.1 & 1391.9 & 37.1 & 97.8 \\
\hline
\end{tabular}




\begin{tabular}{|c|c|c|c|c|c|c|c|c|c|c|c|c|c|c|c|c|c|c|c|}
\hline Analysis & U & $206 \mathrm{~Pb}$ & $\begin{array}{c}\mathrm{U} / \mathrm{T} \\
\mathrm{h}\end{array}$ & $206 \mathrm{~Pb}^{*}$ & \pm & $207 \mathrm{~Pb}^{*}$ & \pm & $\underset{*}{206 \mathrm{~Pb}}$ & \pm & $\begin{array}{c}\text { erro } \\
\mathrm{r}\end{array}$ & $\underset{\star}{206 \mathrm{~Pb}}$ & \pm & $\underset{\star}{207 P b}$ & \pm & $\begin{array}{c}206 \mathrm{~Pb} \\
*\end{array}$ & \pm & $\begin{array}{c}\text { Best } \\
\text { age }\end{array}$ & \pm & Conc \\
\hline & (ppm & $204 \mathrm{~Pb}$ & & $207 \mathrm{~Pb}^{*}$ & $(\%)$ & $235 \mathrm{U}^{*}$ & $(\%)$ & $238 \mathrm{U}$ & (\%) & corr. & $238 \mathrm{U}^{*}$ & (Ma) & $235 \mathrm{U}$ & (Ma) & $\underset{*}{207 P b}$ & (Ma) & (Ma) & (Ma) & (\%) \\
\hline P1004-24 & 40 & 49383 & 1.0 & $\begin{array}{r}11.304 \\
0 \\
\end{array}$ & 3.5 & 2.8297 & 5.2 & 0.2320 & 3.8 & 0.73 & 1344.9 & 46.2 & 1363.4 & 38.8 & 1392.6 & 67.3 & 1392.6 & 67.3 & 96.6 \\
\hline P1004-71 & 129 & $\begin{array}{r}10468 \\
1 \\
\end{array}$ & 1.3 & $\begin{array}{r}10.819 \\
9 \\
\end{array}$ & 0.7 & 3.3067 & 1.2 & 0.2595 & 1.0 & 0.84 & 1487.2 & 13.9 & 1482.6 & 9.7 & 1476.1 & 12.6 & 1476.1 & 12.6 & 100.8 \\
\hline P1004-19 & 61 & 68526 & 2.0 & $\begin{array}{r}10.749 \\
7 \\
\end{array}$ & 1.0 & 3.3860 & 1.6 & 0.2640 & 1.2 & 0.76 & 1510.2 & 16.3 & 1501.2 & 12.5 & 1488.4 & 19.6 & 1488.4 & 19.6 & 101.5 \\
\hline P1004-94 & 132 & 9235 & 1.4 & $\begin{array}{r}10.618 \\
6 \\
\end{array}$ & 1.1 & 3.1008 & 3.4 & 0.2388 & 3.2 & 0.94 & 1380.5 & 39.2 & 1432.9 & 25.7 & 1511.6 & 21.3 & 1511.6 & 21.3 & 91.3 \\
\hline P1004-39 & 83 & 63356 & 1.1 & $\begin{array}{r}10.587 \\
7 \\
\end{array}$ & 1.6 & 3.2984 & 3.2 & 0.2533 & 2.7 & 0.86 & 1455.4 & 35.3 & 1480.7 & 24.6 & 1517.1 & 30.6 & 1517.1 & 30.6 & 95.9 \\
\hline P1004-25 & 75 & 41373 & 2.1 & $\begin{array}{r}10.490 \\
5 \\
\end{array}$ & 1.3 & 3.5550 & 2.0 & 0.2705 & 1.5 & 0.76 & 1543.3 & 20.3 & 1539.6 & 15.5 & 1534.5 & 24.1 & 1534.5 & 24.1 & 100.6 \\
\hline P1004-29 & 83 & 62142 & 2.2 & $\begin{array}{r}10.423 \\
0\end{array}$ & 1.1 & 3.5943 & 1.5 & 0.2717 & 1.0 & 0.66 & 1549.5 & 13.6 & 1548.3 & 11.9 & 1546.6 & 21.1 & 1546.6 & 21.1 & 100.2 \\
\hline P1004-84 & 29 & 53898 & 6.5 & 8.5338 & 1.5 & 5.5904 & 2.3 & 0.3460 & 1.8 & 0.75 & 1915.5 & 29.4 & 1914.6 & 20.2 & 1913.7 & 27.7 & 1913.7 & 27.7 & 100.1 \\
\hline P1004-86 & 115 & 6532 & 1.0 & 8.1995 & 3.4 & 5.9398 & 4.2 & 0.3532 & 2.5 & 0.59 & 1950.0 & 41.2 & 1967.1 & 36.2 & 1985.1 & 60.0 & 1985.1 & 60.0 & 98.2 \\
\hline P1004-83 & 261 & $\begin{array}{r}21667 \\
9 \\
\end{array}$ & 1.2 & 7.5837 & 0.2 & 7.0504 & 1.2 & 0.3878 & 1.2 & 0.99 & 2112.6 & 21.3 & 2117.8 & 10.6 & 2122.9 & 2.9 & 2122.9 & 2.9 & 99.5 \\
\hline P1004-7 & 238 & $\begin{array}{r}19107 \\
7 \\
\end{array}$ & 0.6 & 7.3661 & 0.3 & 7.4546 & 1.0 & 0.3983 & 1.0 & 0.97 & 2161.0 & 17.8 & 2167.6 & 9.0 & 2173.7 & 4.4 & 2173.7 & 4.4 & 99.4 \\
\hline P1004-26 & 131 & $\begin{array}{r}23766 \\
6 \\
\end{array}$ & 1.2 & 5.6820 & 1.0 & $\begin{array}{r}11.836 \\
1\end{array}$ & 2.0 & 0.4878 & 1.8 & 0.88 & 2561.0 & 38.3 & 2591.5 & 19.2 & 2615.5 & 15.9 & 2615.5 & 15.9 & 97.9 \\
\hline P1004-57 & 26 & 95627 & 2.3 & 5.4876 & 1.2 & $\begin{array}{r}12.290 \\
3\end{array}$ & 3.8 & 0.4892 & 3.6 & 0.95 & 2567.0 & 76.7 & 2626.8 & 35.8 & 2673.2 & 19.5 & 2673.2 & 19.5 & 96.0 \\
\hline
\end{tabular}

\begin{tabular}{|c|c|c|c|c|c|c|c|c|c|c|c|c|c|c|c|c|c|c|c|}
\hline Analysis & U & $206 \mathrm{~Pb}$ & $\begin{array}{c}\mathrm{U} / \mathrm{T} \\
\mathrm{h} \\
\end{array}$ & $206 \mathrm{~Pb}^{*}$ & \pm & $207 \mathrm{~Pb}^{*}$ & \pm & $\underset{*}{206 \mathrm{~Pb}}$ & \pm & $\begin{array}{c}\text { erro } \\
\mathrm{r}\end{array}$ & $\underset{*}{206 \mathrm{~Pb}}$ & \pm & $\underset{*}{207 \mathrm{~Pb}}$ & \pm & $\underset{*}{206 \mathrm{~Pb}}$ & \pm & $\begin{array}{l}\text { Best } \\
\text { age }\end{array}$ & \pm & Conc \\
\hline & $\begin{array}{c}(\mathrm{ppm} \\
)\end{array}$ & $204 \mathrm{~Pb}$ & & $207 \mathrm{~Pb}^{*}$ & $(\%)$ & $235 \mathrm{U}^{*}$ & $(\%)$ & $238 \mathrm{U}$ & $(\%)$ & corr. & $238 \mathrm{U}^{*}$ & (Ma) & $235 \mathrm{U}$ & (Ma) & $\underset{*}{207 \mathrm{~Pb}}$ & $(\mathrm{Ma})$ & (Ma) & (Ma) & $(\%)$ \\
\hline P1080-33 & 292 & 38682 & 0.5 & $\begin{array}{r}19.076 \\
5 \\
\end{array}$ & 2.1 & 0.3880 & 3.1 & 0.0537 & 2.3 & 0.74 & 337.1 & 7.6 & 332.9 & 8.9 & 303.8 & 48.4 & 337.1 & 7.6 & NA \\
\hline P1080-93 & 35 & 10325 & 1.1 & $\begin{array}{r}24.422 \\
2 \\
\end{array}$ & $\begin{array}{r}10 . \\
6 \\
\end{array}$ & 0.3293 & $\begin{array}{r}11 . \\
5 \\
\end{array}$ & 0.0583 & 4.5 & 0.39 & 365.4 & 15.9 & 289.0 & 29.0 & -290.9 & 271.4 & 365.4 & 15.9 & NA \\
\hline P1080-57 & 172 & 29054 & 1.5 & $\begin{array}{r}18.015 \\
3 \\
\end{array}$ & 1.9 & 0.4747 & 3.0 & 0.0620 & 2.3 & 0.77 & 387.9 & 8.8 & 394.4 & 9.9 & 432.7 & 43.3 & 387.9 & 8.8 & NA \\
\hline P1080-81 & 50 & 15454 & 1.7 & $\begin{array}{r}17.881 \\
1 \\
\end{array}$ & 5.1 & 0.4799 & 5.2 & 0.0622 & 1.0 & 0.19 & 389.2 & 3.7 & 398.0 & 17.2 & 449.4 & 113.8 & 389.2 & 3.7 & NA \\
\hline P1080-38 & 270 & 72321 & 4.1 & $\begin{array}{r}18.342 \\
0\end{array}$ & 1.7 & 0.4715 & 6.0 & 0.0627 & 5.8 & 0.96 & 392.2 & 22.0 & 392.2 & 19.6 & 392.6 & 38.4 & 392.2 & 22.0 & NA \\
\hline P1080-86 & 547 & $\begin{array}{r}17624 \\
7 \\
\end{array}$ & 15.3 & $\begin{array}{r}18.226 \\
6 \\
\end{array}$ & 1.1 & 0.4767 & 2.7 & 0.0630 & 2.5 & 0.92 & 394.0 & 9.6 & 395.8 & 9.0 & 406.7 & 23.9 & 394.0 & 9.6 & NA \\
\hline P1080-9 & 92 & 36130 & 1.6 & $\begin{array}{r}18.778 \\
8 \\
\end{array}$ & 8.0 & 0.4644 & 8.1 & 0.0633 & 1.3 & 0.16 & 395.4 & 5.0 & 387.3 & 26.0 & 339.6 & 180.7 & 395.4 & 5.0 & NA \\
\hline P1080-64 & 434 & $\begin{array}{r}11373 \\
2 \\
\end{array}$ & 7.9 & $\begin{array}{r}18.266 \\
1 \\
\end{array}$ & 1.8 & 0.4802 & 3.0 & 0.0636 & 2.4 & 0.79 & 397.6 & 9.1 & 398.2 & 9.9 & 401.9 & 41.3 & 397.6 & 9.1 & NA \\
\hline P1080-96 & 221 & 41516 & 1.3 & $\begin{array}{r}18.293 \\
9 \\
\end{array}$ & 2.6 & 0.4799 & 4.7 & 0.0637 & 4.0 & 0.84 & 397.9 & 15.4 & 398.0 & 15.6 & 398.4 & 57.4 & 397.9 & 15.4 & NA \\
\hline P1080-12 & 217 & 11336 & 0.8 & $\begin{array}{r}16.372 \\
7 \\
\end{array}$ & $\begin{array}{r}14 . \\
8 \\
\end{array}$ & 0.5432 & $\begin{array}{r}15 . \\
5 \\
\end{array}$ & 0.0645 & 4.6 & 0.30 & 402.9 & 18.1 & 440.5 & 55.3 & 642.0 & 318.9 & 402.9 & 18.1 & 62.8 \\
\hline P1080-71 & 172 & 52467 & 2.0 & $\begin{array}{r}18.491 \\
2 \\
\end{array}$ & 2.2 & 0.4868 & 2.6 & 0.0653 & 1.4 & 0.55 & 407.7 & 5.7 & 402.8 & 8.6 & 374.3 & 48.4 & 407.7 & 5.7 & 108.9 \\
\hline P1080-84 & 203 & 70996 & 5.3 & $\begin{array}{r}17.730 \\
4 \\
\end{array}$ & 4.4 & 0.5182 & 4.6 & 0.0666 & 1.2 & 0.26 & 415.9 & 4.7 & 423.9 & 15.9 & 468.2 & 98.2 & 415.9 & 4.7 & 88.8 \\
\hline P1080-61 & 622 & $\begin{array}{r}13385 \\
8 \\
\end{array}$ & 4.5 & $\begin{array}{r}18.096 \\
9 \\
\end{array}$ & 1.0 & 0.5108 & 1.3 & 0.0670 & 0.9 & 0.67 & 418.3 & 3.5 & 419.0 & 4.5 & 422.7 & 21.6 & 418.3 & 3.5 & 99.0 \\
\hline P1080-17 & 195 & 32625 & 2.6 & $\begin{array}{r}18.185 \\
3 \\
\end{array}$ & 3.4 & 0.5193 & 3.7 & 0.0685 & 1.4 & 0.37 & 427.0 & 5.7 & 424.7 & 12.8 & 411.8 & 76.2 & 427.0 & 5.7 & 103.7 \\
\hline P1080-15 & 314 & 27163 & 0.5 & $\begin{array}{r}17.917 \\
2 \\
\end{array}$ & 1.5 & 0.5274 & 1.7 & 0.0685 & 0.9 & 0.50 & 427.3 & 3.6 & 430.1 & 6.0 & 444.9 & 33.0 & 427.3 & 3.6 & 96.0 \\
\hline P1080-83 & 59 & 35642 & 4.4 & $\begin{array}{r}18.934 \\
3 \\
\end{array}$ & $\begin{array}{r}10 . \\
7 \\
\end{array}$ & 0.5101 & $\begin{array}{r}10 . \\
8 \\
\end{array}$ & 0.0701 & 1.3 & 0.12 & 436.5 & 5.3 & 418.5 & 37.1 & 320.9 & 244.4 & 436.5 & 5.3 & 136.0 \\
\hline P1080-31 & 145 & 57165 & 2.8 & $\begin{array}{r}18.168 \\
3\end{array}$ & 1.4 & 0.5341 & 1.9 & 0.0704 & 1.3 & 0.67 & 438.4 & 5.3 & 434.5 & 6.6 & 413.9 & 30.8 & 438.4 & 5.3 & 105.9 \\
\hline P1080-98 & 110 & 34382 & 3.2 & $\begin{array}{r}18.104 \\
9 \\
\end{array}$ & 5.3 & 0.5410 & 5.4 & 0.0710 & 0.9 & 0.17 & 442.4 & 3.8 & 439.1 & 19.1 & 421.7 & 118.3 & 442.4 & 3.8 & 104.9 \\
\hline $\mathrm{P} 1080-35$ & 74 & 53188 & 2.3 & $\begin{array}{r}17.548 \\
2 \\
\end{array}$ & 7.0 & 0.5588 & 7.3 & 0.0711 & 2.2 & 0.30 & 442.9 & 9.3 & 450.7 & 26.7 & 491.0 & 154.7 & 442.9 & 9.3 & 90.2 \\
\hline P1080-55 & 47 & 17037 & 1.1 & $\begin{array}{r}19.394 \\
3 \\
\end{array}$ & 9.1 & 0.5128 & 9.2 & 0.0721 & 1.4 & 0.16 & 449.0 & 6.3 & 420.3 & 31.8 & 266.0 & 209.9 & 449.0 & 6.3 & 168.8 \\
\hline P1080-70 & 116 & 20548 & 0.7 & $\begin{array}{r}18.035 \\
0 \\
\end{array}$ & 4.7 & 0.5584 & 4.8 & 0.0730 & 1.0 & 0.21 & 454.4 & 4.3 & 450.5 & 17.4 & 430.3 & 104.2 & 454.4 & 4.3 & 105.6 \\
\hline P1080-99 & 277 & $\begin{array}{r}10638 \\
1 \\
\end{array}$ & 0.7 & $\begin{array}{r}17.710 \\
1 \\
\end{array}$ & 1.5 & 0.5700 & 2.4 & 0.0732 & 1.9 & 0.80 & 455.5 & 8.5 & 458.0 & 9.0 & 470.7 & 32.5 & 455.5 & 8.5 & 96.8 \\
\hline P1080-73 & 164 & 49706 & 20.9 & $\begin{array}{r}17.464 \\
0 \\
\end{array}$ & 3.2 & 0.5803 & 7.3 & 0.0735 & 6.6 & 0.90 & 457.2 & 29.2 & 464.7 & 27.3 & 501.6 & 69.4 & 457.2 & 29.2 & 91.2 \\
\hline
\end{tabular}




\begin{tabular}{|c|c|c|c|c|c|c|c|c|c|c|c|c|c|c|c|c|c|c|c|}
\hline Analysis & u & $206 \mathrm{~Pb}$ & $\begin{array}{c}\mathrm{U} / \mathrm{T} \\
\mathrm{h}\end{array}$ & $206 \mathrm{~Pb}^{*}$ & \pm & $207 \mathrm{~Pb}^{*}$ & \pm & $\underset{*}{206 \mathrm{~Pb}}$ & \pm & $\begin{array}{c}\text { erro } \\
\mathrm{r}\end{array}$ & $\underset{*}{206 \mathrm{~Pb}}$ & \pm & $\underset{*}{207 \mathrm{~Pb}}$ & \pm & $\underset{*}{206 \mathrm{~Pb}}$ & \pm & $\begin{array}{l}\text { Best } \\
\text { age }\end{array}$ & \pm & Conc \\
\hline & $\begin{array}{c}\text { (ppm } \\
\text { ) }\end{array}$ & $204 \mathrm{~Pb}$ & & $207 \mathrm{~Pb}^{*}$ & $(\%)$ & $235 \mathrm{U}^{*}$ & $(\%)$ & $238 \mathrm{U}$ & $(\%)$ & corr. & $238 \mathrm{U}^{*}$ & (Ma) & $235 \mathrm{U}$ & (Ma) & $\underset{*}{207 \mathrm{~Pb}}$ & (Ma) & (Ma) & (Ma) & $(\%)$ \\
\hline P1080-54 & 77 & 20837 & 1.8 & $\begin{array}{r}18.156 \\
2\end{array}$ & 5.7 & 0.5610 & 6.0 & 0.0739 & 1.9 & 0.32 & 459.4 & 8.4 & 452.2 & 21.8 & 415.4 & 126.6 & 459.4 & 8.4 & 110.6 \\
\hline P1080-22 & 174 & 44266 & 4.2 & $\begin{array}{r}15.317 \\
3 \\
\end{array}$ & 4.0 & 0.6668 & 8.2 & 0.0741 & 7.1 & 0.87 & 460.7 & 31.7 & 518.8 & 33.1 & 783.5 & 83.1 & 460.7 & 31.7 & 58.8 \\
\hline P1080-18 & 175 & 55845 & 2.6 & $\begin{array}{r}17.142 \\
3 \\
\end{array}$ & 3.0 & 0.6264 & 3.1 & 0.0779 & 0.7 & 0.23 & 483.4 & 3.3 & 493.8 & 12.1 & 542.4 & 65.8 & 483.4 & 3.3 & 89.1 \\
\hline P1080-41 & 55 & 13145 & 0.5 & $\begin{array}{r}17.432 \\
7 \\
\end{array}$ & 6.9 & 0.6939 & 7.5 & 0.0877 & 2.8 & 0.37 & 542.1 & 14.6 & 535.1 & 31.1 & 505.5 & 152.7 & 542.1 & 14.6 & 107.2 \\
\hline P1080-58 & 90 & 38635 & 0.7 & $\begin{array}{r}17.080 \\
7\end{array}$ & 2.2 & 0.7201 & 2.6 & 0.0892 & 1.3 & 0.51 & 550.9 & 6.9 & 550.7 & 10.9 & 550.2 & 48.5 & 550.9 & 6.9 & 100.1 \\
\hline P1080-97 & 80 & 15155 & 3.5 & $\begin{array}{r}16.694 \\
8\end{array}$ & 4.6 & 0.7466 & 4.7 & 0.0904 & 1.2 & 0.26 & 557.9 & 6.5 & 566.2 & 20.5 & 599.9 & 98.8 & 557.9 & 6.5 & 93.0 \\
\hline P1080-43 & 100 & 42642 & 0.9 & $\begin{array}{r}17.183 \\
0 \\
\end{array}$ & 2.9 & 0.7288 & 3.0 & 0.0908 & 1.0 & 0.32 & 560.4 & 5.3 & 555.8 & 13.0 & 537.2 & 62.7 & 560.4 & 5.3 & 104.3 \\
\hline P1080-69 & 156 & 46211 & 4.1 & $\begin{array}{r}17.153 \\
6\end{array}$ & 2.8 & 0.7622 & 3.3 & 0.0948 & 1.7 & 0.53 & 584.0 & 9.7 & 575.3 & 14.3 & 540.9 & 60.4 & 584.0 & 9.7 & 108.0 \\
\hline P1080-2 & 94 & 38671 & 0.4 & $\begin{array}{r}16.400 \\
8 \\
\end{array}$ & 3.4 & 0.8295 & 3.9 & 0.0987 & 1.9 & 0.47 & 606.6 & 10.7 & 613.3 & 18.0 & 638.3 & 74.3 & 606.6 & 10.7 & 95.0 \\
\hline P1080-59 & 82 & 55686 & 0.7 & $\begin{array}{r}16.502 \\
9 \\
\end{array}$ & 3.6 & 0.8380 & 3.9 & 0.1003 & 1.3 & 0.34 & 616.1 & 7.8 & 618.0 & 17.9 & 624.9 & 78.5 & 616.1 & 7.8 & 98.6 \\
\hline P1080-98 & 336 & $\begin{array}{r}24890 \\
6 \\
\end{array}$ & 1.3 & $\begin{array}{r}16.451 \\
9 \\
\end{array}$ & 0.9 & 0.8659 & 1.6 & 0.1033 & 1.3 & 0.83 & 633.8 & 8.1 & 633.3 & 7.6 & 631.6 & 19.1 & 633.8 & 8.1 & 100.3 \\
\hline P1080-62 & 68 & 25704 & 0.8 & $\begin{array}{r}16.517 \\
3 \\
\end{array}$ & 3.2 & 0.8643 & 3.8 & 0.1035 & 1.9 & 0.52 & 635.1 & 11.8 & 632.5 & 17.8 & 623.0 & 69.7 & 635.1 & 11.8 & 101.9 \\
\hline P1080-42 & 139 & $\begin{array}{r}16356 \\
7\end{array}$ & 1.4 & $\begin{array}{r}16.056 \\
1\end{array}$ & 3.5 & 0.8986 & 3.6 & 0.1046 & 1.1 & 0.30 & 641.5 & 6.7 & 651.0 & 17.5 & 683.8 & 74.1 & 641.5 & 6.7 & 93.8 \\
\hline P1080-26 & 95 & 47781 & 0.6 & $\begin{array}{r}16.490 \\
6 \\
\end{array}$ & 2.7 & 0.8848 & 3.7 & 0.1058 & 2.5 & 0.68 & 648.4 & 15.5 & 643.6 & 17.6 & 626.5 & 58.7 & 648.4 & 15.5 & 103.5 \\
\hline P1080-72 & 78 & 31390 & 1.0 & $\begin{array}{r}16.017 \\
9 \\
\end{array}$ & 2.8 & 0.9678 & 4.0 & 0.1124 & 2.9 & 0.72 & 686.9 & 18.8 & 687.3 & 20.0 & 688.9 & 58.9 & 686.9 & 18.8 & 99.7 \\
\hline P1080-23 & 204 & $\begin{array}{r}10362 \\
7 \\
\end{array}$ & 0.9 & $\begin{array}{r}15.482 \\
3 \\
\end{array}$ & 0.9 & 1.1097 & 1.0 & 0.1246 & 0.5 & 0.50 & 757.0 & 3.6 & 758.0 & 5.4 & 761.0 & 18.4 & 757.0 & 3.6 & 99.5 \\
\hline P1080-8 & 51 & 11365 & 1.3 & $\begin{array}{r}14.201 \\
4\end{array}$ & 5.0 & 1.4787 & 5.6 & 0.1523 & 2.5 & 0.44 & 913.9 & 21.1 & 921.7 & 33.9 & 940.5 & 103.0 & 940.5 & $\begin{array}{r}103 . \\
0\end{array}$ & 97.2 \\
\hline P1080-37 & 57 & 43949 & 3.5 & $\begin{array}{r}13.884 \\
2\end{array}$ & 2.3 & 1.6342 & 3.2 & 0.1646 & 2.3 & 0.71 & 982.1 & 20.7 & 983.5 & 20.2 & 986.6 & 46.1 & 986.6 & 46.1 & 99.5 \\
\hline P1080-56 & 64 & 45150 & 2.6 & $\begin{array}{r}13.872 \\
4 \\
\end{array}$ & 4.1 & 1.7266 & 5.0 & 0.1737 & 2.9 & 0.57 & 1032.6 & 27.4 & 1018.5 & 32.3 & 988.4 & 83.9 & 988.4 & 83.9 & 104.5 \\
\hline P1080-1 & 39 & 24437 & 3.4 & $\begin{array}{r}13.829 \\
8\end{array}$ & 5.9 & 1.6178 & 6.2 & 0.1623 & 1.9 & 0.30 & 969.4 & 16.9 & 977.1 & 39.0 & 994.6 & 120.4 & 994.6 & $\begin{array}{r}120 . \\
4\end{array}$ & 97.5 \\
\hline P1080-68 & 162 & $\begin{array}{r}19206 \\
4\end{array}$ & 2.3 & $\begin{array}{r}13.801 \\
6\end{array}$ & 0.7 & 1.6481 & 2.0 & 0.1650 & 1.9 & 0.94 & 984.3 & 17.5 & 988.8 & 12.9 & 998.7 & 14.4 & 998.7 & 14.4 & 98.6 \\
\hline P1080-91 & 70 & 64197 & 1.1 & $\begin{array}{r}13.767 \\
5 \\
\end{array}$ & 2.4 & 1.6955 & 2.6 & 0.1693 & 0.9 & 0.33 & 1008.3 & 8.0 & 1006.8 & 16.6 & 1003.8 & 49.7 & 1003.8 & 49.7 & 100.4 \\
\hline P1080-25 & 35 & 31010 & 1.5 & $\begin{array}{r}13.656 \\
1\end{array}$ & 4.1 & 1.7904 & 4.4 & 0.1773 & 1.5 & 0.35 & 1052.4 & 14.7 & 1042.0 & 28.6 & 1020.2 & 83.4 & 1020.2 & 83.4 & 103.2 \\
\hline P1080-40 & 68 & 44101 & 1.0 & $\begin{array}{r}13.608 \\
4\end{array}$ & 1.9 & 1.7674 & 2.2 & 0.1744 & 1.1 & 0.51 & 1036.5 & 10.8 & 1033.6 & 14.3 & 1027.3 & 38.2 & 1027.3 & 38.2 & 100.9 \\
\hline P1080-4 & 268 & $\begin{array}{r}11790 \\
4\end{array}$ & 0.9 & $\begin{array}{r}13.599 \\
2\end{array}$ & 0.6 & 1.7414 & 1.1 & 0.1718 & 1.0 & 0.85 & 1021.8 & 9.1 & 1024.0 & 7.3 & 1028.7 & 12.0 & 1028.7 & 12.0 & 99.3 \\
\hline P1080-94 & 44 & 25577 & 2.9 & $\begin{array}{r}13.535 \\
1\end{array}$ & 3.4 & 1.7806 & 3.7 & 0.1748 & 1.4 & 0.37 & 1038.5 & 13.1 & 1038.4 & 23.7 & 1038.2 & 68.4 & 1038.2 & 68.4 & 100.0 \\
\hline P1080-46 & 129 & 66403 & 3.5 & $\begin{array}{r}13.461 \\
5\end{array}$ & 0.9 & 1.7372 & 1.6 & 0.1696 & 1.3 & 0.81 & 1009.9 & 12.0 & 1022.4 & 10.2 & 1049.3 & 18.9 & 1049.3 & 18.9 & 96.3 \\
\hline P1080-47 & 143 & 79627 & 0.9 & $\begin{array}{r}13.356 \\
4\end{array}$ & 1.3 & 1.7711 & 2.7 & 0.1716 & 2.4 & 0.88 & 1020.7 & 22.6 & 1034.9 & 17.7 & 1065.0 & 26.2 & 1065.0 & 26.2 & 95.8 \\
\hline P1080-10 & 34 & 18458 & 1.5 & $\begin{array}{r}13.354 \\
7\end{array}$ & 4.6 & 1.8150 & 4.7 & 0.1758 & 0.9 & 0.19 & 1044.0 & 8.9 & 1050.9 & 30.9 & 1065.3 & 93.2 & 1065.3 & 93.2 & 98.0 \\
\hline P1080-49 & 72 & 82725 & 3.0 & $\begin{array}{r}13.346 \\
7\end{array}$ & 1.4 & 1.9048 & 1.8 & 0.1844 & 1.1 & 0.62 & 1090.9 & 11.0 & 1082.8 & 11.8 & 1066.5 & 28.1 & 1066.5 & 28.1 & 102.3 \\
\hline P1080-60 & 115 & $\begin{array}{r}15475 \\
3\end{array}$ & 1.2 & $\begin{array}{r}13.344 \\
7\end{array}$ & 1.2 & 1.8126 & 1.9 & 0.1754 & 1.4 & 0.76 & 1042.0 & 13.7 & 1050.0 & 12.3 & 1066.8 & 24.5 & 1066.8 & 24.5 & 97.7 \\
\hline P1080-16 & 51 & 40784 & 1.0 & $\begin{array}{r}13.311 \\
3\end{array}$ & 2.4 & 1.8560 & 2.8 & 0.1792 & 1.4 & 0.50 & 1062.5 & 13.6 & 1065.6 & 18.3 & 1071.8 & 48.2 & 1071.8 & 48.2 & 99.1 \\
\hline P1080-34 & 78 & $\begin{array}{r}20357 \\
9\end{array}$ & 1.6 & $\begin{array}{r}13.206 \\
9\end{array}$ & 0.7 & 1.9249 & 2.0 & 0.1844 & 1.8 & 0.93 & 1090.9 & 18.3 & 1089.8 & 13.1 & 1087.6 & 14.6 & 1087.6 & 14.6 & 100.3 \\
\hline P1080-78 & 15 & 26340 & 1.7 & $\begin{array}{r}13.188 \\
8\end{array}$ & 7.4 & 1.9719 & 7.8 & 0.1886 & 2.2 & 0.28 & 1113.9 & 22.6 & 1106.0 & 52.3 & 1090.4 & 149.2 & 1090.4 & $\begin{array}{r}149 . \\
2\end{array}$ & 102.2 \\
\hline $\begin{array}{l}\text { P1080 } \\
\text { prob } 51\end{array}$ & 124 & 85621 & 1.1 & $\begin{array}{r}12.865 \\
2\end{array}$ & 1.2 & 2.1525 & 1.3 & 0.2008 & 0.6 & 0.48 & 1179.9 & 6.9 & 1165.9 & 9.3 & 1139.9 & 23.3 & 1139.9 & 23.3 & 103.5 \\
\hline P1080-21 & 353 & $\begin{array}{r}70377 \\
2 \\
\end{array}$ & 1.5 & $\begin{array}{r}12.851 \\
9\end{array}$ & 0.6 & 2.0638 & 1.5 & 0.1924 & 1.4 & 0.93 & 1134.2 & 14.8 & 1136.9 & 10.5 & 1142.0 & 11.2 & 1142.0 & 11.2 & 99.3 \\
\hline P1080-76 & 193 & $\begin{array}{r}16032 \\
0\end{array}$ & 1.7 & $\begin{array}{r}12.787 \\
1\end{array}$ & 0.9 & 2.1528 & 2.1 & 0.1997 & 1.9 & 0.90 & 1173.4 & 20.5 & 1165.9 & 14.7 & 1152.0 & 18.4 & 1152.0 & 18.4 & 101.9 \\
\hline P1080-36 & 202 & $\begin{array}{r}11935 \\
7\end{array}$ & 1.2 & $\begin{array}{r}12.677 \\
1\end{array}$ & 1.0 & 2.1496 & 2.4 & 0.1976 & 2.2 & 0.91 & 1162.6 & 23.3 & 1164.9 & 16.7 & 1169.2 & 20.0 & 1169.2 & 20.0 & 99.4 \\
\hline P1080-63 & 135 & $\begin{array}{r}11840 \\
3\end{array}$ & 0.7 & $\begin{array}{r}12.648 \\
6\end{array}$ & 0.9 & 2.2286 & 4.2 & 0.2044 & 4.1 & 0.98 & 1199.2 & 45.3 & 1190.1 & 29.8 & 1173.7 & 18.6 & 1173.7 & 18.6 & 102.2 \\
\hline
\end{tabular}




\begin{tabular}{|c|c|c|c|c|c|c|c|c|c|c|c|c|c|c|c|c|c|c|c|}
\hline Analysis & $\mathrm{u}$ & $206 \mathrm{~Pb}$ & $\begin{array}{c}\mathrm{U} / \mathrm{T} \\
\mathrm{h}\end{array}$ & $206 \mathrm{~Pb}^{*}$ & \pm & $207 \mathrm{~Pb}^{*}$ & \pm & $\underset{*}{206 \mathrm{~Pb}}$ & \pm & $\begin{array}{c}\text { erro } \\
\mathrm{r}\end{array}$ & $\underset{*}{206 \mathrm{~Pb}}$ & \pm & $\underset{*}{207 \mathrm{~Pb}}$ & \pm & $\underset{*}{206 \mathrm{~Pb}}$ & \pm & $\begin{array}{l}\text { Best } \\
\text { age }\end{array}$ & \pm & Conc \\
\hline & $\begin{array}{c}(\mathrm{ppm} \\
)\end{array}$ & $204 \mathrm{~Pb}$ & & $207 \mathrm{~Pb}^{*}$ & $(\%)$ & $235 \mathrm{U}^{*}$ & $(\%)$ & $238 \mathrm{U}$ & $(\%)$ & corr. & $238 \mathrm{U}^{*}$ & (Ma) & $235 \mathrm{U}$ & (Ma) & $\underset{*}{207 P b}$ & (Ma) & (Ma) & (Ma) & $(\%)$ \\
\hline P1080-77 & 49 & 51402 & 1.0 & $\begin{array}{r}12.518 \\
8 \\
\end{array}$ & 2.8 & 2.1311 & 2.8 & 0.1935 & 0.5 & 0.19 & 1140.3 & 5.5 & 1158.9 & 19.4 & 1194.0 & 54.4 & 1194.0 & 54.4 & 95.5 \\
\hline P1080-92 & 142 & $\begin{array}{r}11516 \\
8 \\
\end{array}$ & 2.1 & $\begin{array}{r}12.503 \\
7 \\
\end{array}$ & 0.5 & 2.1953 & 1.1 & 0.1991 & 0.9 & 0.87 & 1170.4 & 10.0 & 1179.5 & 7.5 & 1196.4 & 10.5 & 1196.4 & 10.5 & 97.8 \\
\hline P1080-74 & 109 & $\begin{array}{r}16238 \\
3 \\
\end{array}$ & 1.9 & $\begin{array}{r}12.346 \\
0 \\
\end{array}$ & 1.2 & 2.2388 & 2.2 & 0.2005 & 1.9 & 0.84 & 1177.8 & 20.3 & 1193.3 & 15.8 & 1221.4 & 24.0 & 1221.4 & 24.0 & 96.4 \\
\hline P1080-82 & 163 & $\begin{array}{r}10457 \\
0 \\
\end{array}$ & 1.7 & $\begin{array}{r}12.243 \\
5 \\
\end{array}$ & 0.6 & 2.3270 & 0.9 & 0.2066 & 0.7 & 0.73 & 1210.8 & 7.6 & 1220.6 & 6.7 & 1237.8 & 12.6 & 1237.8 & 12.6 & 97.8 \\
\hline P1080-95 & 63 & 26281 & 2.3 & $\begin{array}{r}12.241 \\
7 \\
\end{array}$ & 1.7 & 2.2016 & 3.2 & 0.1955 & 2.7 & 0.85 & 1150.9 & 28.3 & 1181.5 & 22.1 & 1238.1 & 32.7 & 1238.1 & 32.7 & 93.0 \\
\hline $\mathrm{P} 1080-3$ & 468 & $\begin{array}{r}38194 \\
5 \\
\end{array}$ & 1.6 & $\begin{array}{r}11.920 \\
1 \\
\end{array}$ & 0.2 & 2.5065 & 1.1 & 0.2167 & 1.0 & 0.97 & 1264.4 & 11.8 & 1273.9 & 7.7 & 1290.0 & 4.7 & 1290.0 & 4.7 & 98.0 \\
\hline P1080-48 & 177 & 99206 & 1.9 & $\begin{array}{r}11.737 \\
3 \\
\end{array}$ & 0.6 & 2.6889 & 1.5 & 0.2289 & 1.3 & 0.91 & 1328.7 & 16.1 & 1325.4 & 10.9 & 1320.0 & 11.9 & 1320.0 & 11.9 & 100.7 \\
\hline P1080-52 & 57 & 35515 & 1.7 & $\begin{array}{r}11.690 \\
6 \\
\end{array}$ & 1.8 & 2.7799 & 2.1 & 0.2357 & 1.1 & 0.52 & 1364.3 & 13.5 & 1350.2 & 15.6 & 1327.8 & 34.4 & 1327.8 & 34.4 & 102.8 \\
\hline P1080-14 & 574 & 62543 & 1.8 & $\begin{array}{r}11.648 \\
4\end{array}$ & 0.7 & 2.4958 & 1.3 & 0.2108 & 1.1 & 0.84 & 1233.3 & 12.2 & 1270.8 & 9.4 & 1334.8 & 13.5 & 1334.8 & 13.5 & 92.4 \\
\hline P1080-89 & 119 & 72210 & 1.7 & $\begin{array}{r}11.332 \\
3 \\
\end{array}$ & 0.9 & 2.8169 & 2.2 & 0.2315 & 2.0 & 0.91 & 1342.5 & 24.1 & 1360.0 & 16.3 & 1387.8 & 17.2 & 1387.8 & 17.2 & 96.7 \\
\hline P1080-32 & 55 & 48675 & 1.9 & $\begin{array}{r}11.321 \\
3 \\
\end{array}$ & 2.3 & 2.9335 & 2.4 & 0.2409 & 0.7 & 0.29 & 1391.2 & 8.7 & 1390.6 & 18.1 & 1389.6 & 44.0 & 1389.6 & 44.0 & 100.1 \\
\hline P1080-50 & 178 & $\begin{array}{r}10257 \\
3 \\
\end{array}$ & 2.5 & $\begin{array}{r}10.946 \\
3 \\
\end{array}$ & 0.5 & 3.1614 & 1.2 & 0.2510 & 1.1 & 0.89 & 1443.5 & 14.1 & 1447.8 & 9.4 & 1454.0 & 10.4 & 1454.0 & 10.4 & 99.3 \\
\hline P1080-27 & 141 & $\begin{array}{r}29501 \\
4 \\
\end{array}$ & 2.2 & $\begin{array}{r}10.737 \\
0 \\
\end{array}$ & 0.5 & 3.3681 & 1.2 & 0.2623 & 1.1 & 0.92 & 1501.5 & 14.9 & 1497.0 & 9.4 & 1490.6 & 8.7 & 1490.6 & 8.7 & 100.7 \\
\hline P1080-6 & 53 & 56364 & 0.7 & 9.9902 & 1.3 & 4.0412 & 1.6 & 0.2928 & 0.9 & 0.58 & 1655.5 & 13.5 & 1642.5 & 12.9 & 1625.9 & 24.0 & 1625.9 & 24.0 & 101.8 \\
\hline P1080-87 & 108 & 65282 & 2.0 & 9.9033 & 1.2 & 4.1463 & 1.5 & 0.2978 & 0.9 & 0.60 & 1680.4 & 13.4 & 1663.5 & 12.4 & 1642.1 & 22.5 & 1642.1 & 22.5 & 102.3 \\
\hline P1080-44 & 77 & 55498 & 0.7 & 9.7075 & 0.9 & 4.2327 & 1.4 & 0.2980 & 1.0 & 0.74 & 1681.4 & 14.8 & 1680.4 & 11.1 & 1679.1 & 16.9 & 1679.1 & 16.9 & 100.1 \\
\hline P1080-88 & 110 & $\begin{array}{r}12921 \\
1 \\
\end{array}$ & 1.9 & 8.6467 & 0.7 & 5.4553 & 2.2 & 0.3421 & 2.0 & 0.95 & 1896.8 & 33.7 & 1893.6 & 18.6 & 1890.0 & 12.7 & 1890.0 & 12.7 & 100.4 \\
\hline P1080-11 & 16 & 12008 & 1.2 & 7.8412 & 1.4 & 6.6156 & 2.0 & 0.3762 & 1.5 & 0.73 & 2058.6 & 25.9 & 2061.4 & 17.8 & 2064.2 & 24.4 & 2064.2 & 24.4 & 99.7 \\
\hline P1080-30 & 181 & $\begin{array}{r}31206 \\
3 \\
\end{array}$ & 1.8 & 7.5701 & 0.2 & 6.8490 & 1.5 & 0.3760 & 1.5 & 0.99 & 2057.7 & 25.9 & 2092.1 & 13.1 & 2126.0 & 2.9 & 2126.0 & 2.9 & 96.8 \\
\hline P1080-75 & 41 & $\begin{array}{r}12613 \\
1 \\
\end{array}$ & 1.5 & 7.3963 & 0.9 & 7.5951 & 1.3 & 0.4074 & 1.0 & 0.74 & 2203.1 & 17.9 & 2184.3 & 11.7 & 2166.6 & 15.4 & 2166.6 & 15.4 & 101.7 \\
\hline P1080-65 & 255 & $\begin{array}{r}79906 \\
1 \\
\end{array}$ & 2.0 & 7.3945 & 0.4 & 7.0806 & 1.6 & 0.3797 & 1.5 & 0.97 & 2075.0 & 27.3 & 2121.6 & 14.1 & 2167.0 & 6.5 & 2167.0 & 6.5 & 95.8 \\
\hline P1080-24 & 140 & $\begin{array}{r}16586 \\
7 \\
\end{array}$ & 0.9 & 6.7206 & 0.3 & 8.3774 & 0.7 & 0.4083 & 0.6 & 0.87 & 2207.3 & 11.3 & 2272.7 & 6.3 & 2332.1 & 5.8 & 2332.1 & 5.8 & 94.6 \\
\hline P1080-53 & 36 & 44381 & 3.6 & 6.2277 & 0.5 & $\begin{array}{r}10.414 \\
3 \\
\end{array}$ & 1.1 & 0.4704 & 1.0 & 0.89 & 2485.3 & 19.9 & 2472.3 & 10.0 & 2461.7 & 8.4 & 2461.7 & 8.4 & 101.0 \\
\hline P1080-13 & 122 & $\begin{array}{r}32547 \\
0\end{array}$ & 1.4 & 6.1550 & 0.4 & $\begin{array}{r}10.779 \\
7\end{array}$ & 1.1 & 0.4812 & 1.0 & 0.94 & 2532.5 & 21.3 & 2504.3 & 10.0 & 2481.5 & 6.2 & 2481.5 & 6.2 & 102.1 \\
\hline
\end{tabular}

\begin{tabular}{|c|c|c|c|c|c|c|c|c|c|c|c|c|c|c|c|c|c|c|c|}
\hline Analysis & $\mathrm{U}$ & $206 \mathrm{~Pb}$ & $\begin{array}{c}\mathrm{U} / \mathrm{T} \\
\mathrm{h}\end{array}$ & $206 \mathrm{~Pb}^{*}$ & \pm & $207 \mathrm{~Pb}^{*}$ & \pm & $\underset{*}{206 \mathrm{~Pb}}$ & \pm & $\begin{array}{c}\text { erro } \\
\mathrm{r}\end{array}$ & $\underset{*}{206 \mathrm{~Pb}}$ & \pm & $\underset{*}{207 \mathrm{~Pb}}$ & \pm & $\underset{*}{206 \mathrm{~Pb}}$ & \pm & $\begin{array}{c}\text { Best } \\
\text { age }\end{array}$ & \pm & Conc \\
\hline & $\begin{array}{c}\text { (ppm } \\
\text { ) }\end{array}$ & $204 \mathrm{~Pb}$ & & $207 \mathrm{~Pb}^{*}$ & (\%) & $235 \mathrm{U}^{*}$ & (\%) & $238 \mathrm{U}$ & (\%) & corr. & $238 \mathrm{U}^{*}$ & (Ma) & $235 \mathrm{U}$ & (Ma) & $\underset{*}{207 \mathrm{~Pb}}$ & (Ma) & (Ma) & (Ma) & (\%) \\
\hline PE-30 & 284 & 32353 & 1.0 & $\begin{array}{r}19.303 \\
8 \\
\end{array}$ & 3.2 & 0.3302 & 3.3 & 0.0462 & 1.1 & 0.32 & 291.4 & 3.1 & 289.7 & 8.4 & 276.8 & 72.4 & 291.4 & 3.1 & NA \\
\hline PE-73 & 147 & 36319 & 0.8 & $\begin{array}{r}18.818 \\
7 \\
\end{array}$ & 3.4 & 0.3396 & 3.7 & 0.0464 & 1.4 & 0.38 & 292.1 & 4.0 & 296.9 & 9.5 & 334.7 & 77.1 & 292.1 & 4.0 & NA \\
\hline PE-20 & 118 & 18387 & 1.6 & $\begin{array}{r}18.779 \\
0 \\
\end{array}$ & 5.9 & 0.3410 & 6.9 & 0.0464 & 3.5 & 0.51 & 292.6 & 10.1 & 297.9 & 17.8 & 339.5 & 134.2 & 292.6 & 10.1 & NA \\
\hline $\mathrm{PE}-17$ & 110 & 16815 & 0.9 & $\begin{array}{r}19.356 \\
2 \\
\end{array}$ & 8.0 & 0.3322 & 8.1 & 0.0466 & 0.9 & 0.12 & 293.9 & 2.7 & 291.3 & 20.4 & 270.5 & 183.9 & 293.9 & 2.7 & NA \\
\hline$P E-47$ & 185 & 77646 & 1.5 & $\begin{array}{r}19.281 \\
9 \\
\end{array}$ & 3.7 & 0.3382 & 4.1 & 0.0473 & 1.9 & 0.46 & 297.9 & 5.6 & 295.8 & 10.6 & 279.4 & 83.8 & 297.9 & 5.6 & NA \\
\hline PE-58 & 154 & 33642 & 1.1 & $\begin{array}{r}19.084 \\
5\end{array}$ & 3.2 & 0.3496 & 3.5 & 0.0484 & 1.4 & 0.41 & 304.7 & 4.3 & 304.4 & 9.3 & 302.8 & 73.4 & 304.7 & 4.3 & NA \\
\hline PE-68 & 40 & 9403 & 2.0 & $\begin{array}{r}19.475 \\
2 \\
\end{array}$ & $\begin{array}{r}20 . \\
6 \\
\end{array}$ & 0.3480 & $\begin{array}{r}21 . \\
3 \\
\end{array}$ & 0.0492 & 5.0 & 0.24 & 309.3 & 15.2 & 303.2 & 55.8 & 256.5 & 479.0 & 309.3 & 15.2 & $\mathrm{NA}$ \\
\hline PE-93 & 618 & 49162 & 1.0 & $\begin{array}{r}18.971 \\
7 \\
\end{array}$ & 0.9 & 0.3693 & 1.4 & 0.0508 & 1.1 & 0.78 & 319.5 & 3.4 & 319.1 & 3.8 & 316.3 & 19.5 & 319.5 & 3.4 & NA \\
\hline PE-36 & 225 & 37498 & 2.0 & $\begin{array}{r}18.087 \\
4\end{array}$ & 2.5 & 0.5002 & 2.8 & 0.0656 & 1.3 & 0.46 & 409.7 & 5.2 & 411.9 & 9.6 & 423.8 & 56.4 & 409.7 & 5.2 & 96.7 \\
\hline$P E-14$ & 175 & 30289 & 0.9 & $\begin{array}{r}18.399 \\
6 \\
\end{array}$ & 2.8 & 0.4947 & 2.9 & 0.0660 & 0.9 & 0.31 & 412.1 & 3.6 & 408.1 & 9.9 & 385.5 & 62.8 & 412.1 & 3.6 & 106.9 \\
\hline PE-32 & 16 & 3781 & 0.6 & $\begin{array}{r}21.408 \\
4 \\
\end{array}$ & $\begin{array}{r}55 . \\
1 \\
\end{array}$ & 0.4273 & $\begin{array}{r}55 . \\
3 \\
\end{array}$ & 0.0663 & 4.7 & 0.08 & 414.1 & 18.9 & 361.2 & $\begin{array}{r}169 . \\
8 \\
\end{array}$ & 34.5 & $\begin{array}{r}1423 . \\
3 \\
\end{array}$ & 414.1 & 18.9 & 1201.4 \\
\hline PE-24 & 112 & 10754 & 0.5 & $\begin{array}{r}18.257 \\
9 \\
\end{array}$ & 2.8 & 0.5152 & 3.2 & 0.0682 & 1.5 & 0.46 & 425.4 & 6.1 & 421.9 & 11.0 & 402.9 & 63.4 & 425.4 & 6.1 & 105.6 \\
\hline
\end{tabular}




\begin{tabular}{|c|c|c|c|c|c|c|c|c|c|c|c|c|c|c|c|c|c|c|c|}
\hline Analysis & U & $206 \mathrm{~Pb}$ & $\begin{array}{c}\mathrm{U} / \mathrm{T} \\
\mathrm{h}\end{array}$ & $206 \mathrm{~Pb}^{\star}$ & \pm & $207 \mathrm{~Pb}^{*}$ & \pm & $\underset{*}{206 \mathrm{~Pb}}$ & \pm & $\begin{array}{c}\text { erro } \\
\mathrm{r}\end{array}$ & $\underset{\star}{206 \mathrm{~Pb}}$ & \pm & $\underset{*}{207 \mathrm{~Pb}}$ & \pm & $\underset{*}{206 \mathrm{~Pb}}$ & \pm & $\begin{array}{c}\text { Best } \\
\text { age }\end{array}$ & \pm & Conc \\
\hline & $\begin{array}{c}\text { (ppm } \\
\text { ) }\end{array}$ & $204 \mathrm{~Pb}$ & & $207 \mathrm{~Pb}^{*}$ & $(\%)$ & $235 \mathrm{U}^{*}$ & $(\%)$ & $238 \mathrm{U}$ & (\%) & corr. & $238 \mathrm{U}^{*}$ & (Ma) & $235 \mathrm{U}$ & (Ma) & $\underset{*}{207 \mathrm{~Pb}}$ & (Ma) & (Ma) & (Ma) & $(\%)$ \\
\hline PE-75 & 133 & 49525 & 2.1 & $\begin{array}{r}17.710 \\
9 \\
\end{array}$ & 2.4 & 0.5370 & 2.7 & 0.0690 & 1.3 & 0.49 & 430.0 & 5.6 & 436.4 & 9.7 & 470.6 & 52.7 & 430.0 & 5.6 & 91.4 \\
\hline PE-48 & 390 & $\begin{array}{r}13648 \\
2 \\
\end{array}$ & 2.4 & $\begin{array}{r}18.035 \\
1 \\
\end{array}$ & 1.5 & 0.5298 & 1.8 & 0.0693 & 0.9 & 0.49 & 431.9 & 3.7 & 431.7 & 6.2 & 430.3 & 34.3 & 431.9 & 3.7 & 100.4 \\
\hline PE-78 & 373 & $\begin{array}{r}12944 \\
8 \\
\end{array}$ & 2.7 & $\begin{array}{r}17.307 \\
7 \\
\end{array}$ & 1.0 & 0.6767 & 1.4 & 0.0849 & 1.1 & 0.74 & 525.6 & 5.3 & 524.8 & 5.9 & 521.3 & 21.2 & 525.6 & 5.3 & 100.8 \\
\hline PE-91 & 100 & 56238 & 1.0 & $\begin{array}{r}17.430 \\
2\end{array}$ & 3.3 & 0.6794 & 3.6 & 0.0859 & 1.3 & 0.36 & 531.2 & 6.6 & 526.4 & 14.7 & 505.8 & 73.4 & 531.2 & 6.6 & 105.0 \\
\hline PE-5 & 57 & 11090 & 0.8 & $\begin{array}{r}16.847 \\
6 \\
\end{array}$ & 7.0 & 0.7067 & 7.4 & 0.0863 & 2.3 & 0.31 & 533.9 & 11.9 & 542.8 & 31.1 & 580.2 & 152.5 & 533.9 & 11.9 & 92.0 \\
\hline PE-9 & 47 & 7358 & 0.8 & $\begin{array}{r}17.606 \\
2 \\
\end{array}$ & 9.6 & 0.6887 & $\begin{array}{r}10 . \\
3 \\
\end{array}$ & 0.0879 & 3.7 & 0.36 & 543.3 & 19.3 & 532.0 & 42.5 & 483.7 & 211.8 & 543.3 & 19.3 & 112.3 \\
\hline PE-54 & 55 & 19511 & 0.7 & $\begin{array}{r}17.746 \\
0 \\
\end{array}$ & 5.5 & 0.6869 & 5.7 & 0.0884 & 1.5 & 0.27 & 546.1 & 8.0 & 530.9 & 23.6 & 466.2 & 121.6 & 546.1 & 8.0 & 117.1 \\
\hline PE-23 & 81 & 31830 & 2.1 & $\begin{array}{r}17.059 \\
1 \\
\end{array}$ & 6.0 & 0.7185 & 6.3 & 0.0889 & 2.0 & 0.32 & 549.0 & 10.7 & 549.8 & 26.8 & 553.0 & 130.4 & 549.0 & 10.7 & 99.3 \\
\hline PE-64 & 39 & 10015 & 1.0 & $\begin{array}{r}16.362 \\
7 \\
\end{array}$ & 7.6 & 0.7517 & 7.7 & 0.0892 & 1.3 & 0.17 & 550.8 & 7.1 & 569.2 & 33.6 & 643.3 & 163.5 & 550.8 & 7.1 & 85.6 \\
\hline PE-81 & 81 & 18253 & 0.7 & $\begin{array}{r}17.226 \\
7 \\
\end{array}$ & 3.4 & 0.7143 & 3.7 & 0.0892 & 1.6 & 0.42 & 551.1 & 8.4 & 547.3 & 15.8 & 531.7 & 74.0 & 551.1 & 8.4 & 103.6 \\
\hline PE-52 & 86 & 21911 & 0.9 & $\begin{array}{r}17.056 \\
5 \\
\end{array}$ & 4.0 & 0.7222 & 4.2 & 0.0893 & 1.3 & 0.31 & 551.6 & 6.8 & 552.0 & 18.0 & 553.3 & 87.7 & 551.6 & 6.8 & 99.7 \\
\hline PE-77 & 86 & 23678 & 1.6 & $\begin{array}{r}17.161 \\
2 \\
\end{array}$ & 5.8 & 0.7197 & 6.0 & 0.0896 & 1.6 & 0.26 & 553.1 & 8.3 & 550.5 & 25.6 & 540.0 & 127.5 & 553.1 & 8.3 & 102.4 \\
\hline PE-51 & 40 & 26050 & 0.3 & $\begin{array}{r}16.430 \\
0 \\
\end{array}$ & 8.3 & 0.7530 & 8.7 & 0.0897 & 2.8 & 0.32 & 553.9 & 14.7 & 570.0 & 38.0 & 634.5 & 177.9 & 553.9 & 14.7 & 87.3 \\
\hline PE-94 & 179 & 62374 & 0.9 & $\begin{array}{r}16.974 \\
9 \\
\end{array}$ & 1.8 & 0.7341 & 3.5 & 0.0904 & 3.0 & 0.86 & 557.7 & 15.9 & 558.9 & 14.9 & 563.8 & 38.8 & 557.7 & 15.9 & 98.9 \\
\hline PE-50 & 151 & 39021 & 5.4 & $\begin{array}{r}17.415 \\
1 \\
\end{array}$ & 2.8 & 0.7210 & 3.0 & 0.0911 & 1.0 & 0.34 & 561.8 & 5.6 & 551.2 & 12.8 & 507.8 & 62.3 & 561.8 & 5.6 & 110.6 \\
\hline PE-71 & 41 & 9276 & 1.2 & $\begin{array}{r}17.417 \\
4 \\
\end{array}$ & 7.3 & 0.7267 & 7.5 & 0.0918 & 1.8 & 0.24 & 566.2 & 9.8 & 554.6 & 32.2 & 507.4 & 161.1 & 566.2 & 9.8 & 111.6 \\
\hline PE-56 & 65 & 16847 & 1.8 & $\begin{array}{r}17.000 \\
1 \\
\end{array}$ & 5.0 & 0.7459 & 5.2 & 0.0920 & 1.4 & 0.26 & 567.2 & 7.4 & 565.8 & 22.5 & 560.6 & 109.0 & 567.2 & 7.4 & 101.2 \\
\hline PE-53 & 118 & 32347 & 2.3 & $\begin{array}{r}17.240 \\
6 \\
\end{array}$ & 3.0 & 0.7395 & 4.9 & 0.0925 & 3.8 & 0.78 & 570.1 & 20.8 & 562.1 & 21.0 & 529.9 & 66.1 & 570.1 & 20.8 & 107.6 \\
\hline PE-46 & 102 & 31053 & 1.0 & $\begin{array}{r}16.899 \\
4 \\
\end{array}$ & 5.4 & 0.7569 & 5.6 & 0.0928 & 1.2 & 0.22 & 571.9 & 6.7 & 572.2 & 24.3 & 573.5 & 117.9 & 571.9 & 6.7 & 99.7 \\
\hline PE-74 & 111 & 34451 & 0.8 & $\begin{array}{r}16.822 \\
8 \\
\end{array}$ & 3.1 & 0.7610 & 3.3 & 0.0929 & 1.0 & 0.31 & 572.4 & 5.5 & 574.6 & 14.4 & 583.3 & 67.6 & 572.4 & 5.5 & 98.1 \\
\hline PE-60 & 93 & 29626 & 1.0 & $\begin{array}{r}16.718 \\
6 \\
\end{array}$ & 4.5 & 0.7703 & 4.6 & 0.0934 & 1.1 & 0.23 & 575.7 & 5.8 & 580.0 & 20.4 & 596.9 & 97.2 & 575.7 & 5.8 & 96.4 \\
\hline PE-39 & 26 & 5341 & 1.2 & $\begin{array}{r}17.590 \\
1 \\
\end{array}$ & $\begin{array}{r}15 . \\
4 \\
\end{array}$ & 0.7518 & $\begin{array}{r}15 . \\
6 \\
\end{array}$ & 0.0959 & 2.8 & 0.18 & 590.4 & 15.6 & 569.3 & 68.2 & 485.7 & 341.0 & 590.4 & 15.6 & 121.5 \\
\hline PE-43 & 22 & 9896 & 1.1 & $\begin{array}{r}17.143 \\
0 \\
\end{array}$ & $\begin{array}{r}19 . \\
5 \\
\end{array}$ & 0.7730 & $\begin{array}{r}19 . \\
8 \\
\end{array}$ & 0.0961 & 3.7 & 0.19 & 591.6 & 21.2 & 581.5 & 88.0 & 542.3 & 429.6 & 591.6 & 21.2 & 109.1 \\
\hline PE-59 & 92 & 31540 & 0.5 & $\begin{array}{r}17.105 \\
1 \\
\end{array}$ & 4.8 & 0.7758 & 5.0 & 0.0962 & 1.1 & 0.22 & 592.3 & 6.2 & 583.1 & 22.0 & 547.1 & 105.9 & 592.3 & 6.2 & 108.3 \\
\hline PE-44 & 39 & 12950 & 3.3 & $\begin{array}{r}16.793 \\
6 \\
\end{array}$ & 7.3 & 0.8121 & 7.6 & 0.0989 & 2.3 & 0.30 & 608.1 & 13.4 & 603.7 & 34.8 & 587.1 & 158.2 & 608.1 & 13.4 & 103.6 \\
\hline PE-70 & 252 & 18645 & 1.2 & $\begin{array}{r}16.205 \\
8\end{array}$ & 1.0 & 0.8438 & 1.8 & 0.0992 & 1.5 & 0.84 & 609.6 & 8.7 & 621.2 & 8.3 & 664.0 & 20.7 & 609.6 & 8.7 & 91.8 \\
\hline PE-84 & 90 & 19527 & 1.7 & $\begin{array}{r}16.385 \\
2\end{array}$ & 5.2 & 0.8496 & 5.5 & 0.1010 & 1.5 & 0.28 & 620.1 & 8.9 & 624.4 & 25.4 & 640.3 & 112.7 & 620.1 & 8.9 & 96.8 \\
\hline PE-83 & 108 & 44310 & 1.5 & $\begin{array}{r}16.599 \\
5\end{array}$ & 2.4 & 0.8441 & 2.5 & 0.1016 & 0.8 & 0.31 & 623.9 & 4.5 & 621.4 & 11.5 & 612.3 & 51.1 & 623.9 & 4.5 & 101.9 \\
\hline PE-8 & 171 & 47697 & 0.9 & $\begin{array}{r}16.542 \\
3 \\
\end{array}$ & 2.1 & 0.8472 & 3.4 & 0.1016 & 2.7 & 0.78 & 624.0 & 15.9 & 623.1 & 15.9 & 619.7 & 45.9 & 624.0 & 15.9 & 100.7 \\
\hline PE-45 & 99 & 40524 & 1.5 & $\begin{array}{r}16.232 \\
0 \\
\end{array}$ & 2.2 & 0.8640 & 2.7 & 0.1017 & 1.7 & 0.61 & 624.4 & 9.9 & 632.3 & 12.8 & 660.5 & 46.4 & 624.4 & 9.9 & 94.5 \\
\hline PE-21 & 96 & 44118 & 0.8 & $\begin{array}{r}16.579 \\
6 \\
\end{array}$ & 3.1 & 0.8476 & 3.3 & 0.1019 & 0.9 & 0.27 & 625.6 & 5.3 & 623.3 & 15.2 & 614.9 & 67.6 & 625.6 & 5.3 & 101.7 \\
\hline PE-6 & 145 & 36758 & 2.0 & $\begin{array}{r}16.689 \\
6 \\
\end{array}$ & 1.7 & 0.8456 & 2.2 & 0.1024 & 1.4 & 0.61 & 628.2 & 8.1 & 622.3 & 10.3 & 600.6 & 37.9 & 628.2 & 8.1 & 104.6 \\
\hline PE-25 & 43 & 12605 & 0.5 & $\begin{array}{r}16.565 \\
3 \\
\end{array}$ & 9.6 & 0.8521 & 9.8 & 0.1024 & 2.1 & 0.21 & 628.3 & 12.6 & 625.8 & 45.8 & 616.7 & 206.9 & 628.3 & 12.6 & 101.9 \\
\hline PE-66 & 69 & 63527 & 1.0 & $\begin{array}{r}15.828 \\
8 \\
\end{array}$ & 4.2 & 0.8973 & 4.4 & 0.1030 & 1.2 & 0.27 & 632.1 & 7.0 & 650.3 & 20.9 & 714.2 & 89.1 & 632.1 & 7.0 & 88.5 \\
\hline PE-34 & 168 & 85447 & 1.5 & $\begin{array}{r}16.323 \\
0 \\
\end{array}$ & 1.0 & 0.9004 & 1.1 & 0.1066 & 0.4 & 0.37 & 652.9 & 2.5 & 651.9 & 5.2 & 648.5 & 21.7 & 652.9 & 2.5 & 100.7 \\
\hline PE-19 & 217 & 98276 & 2.7 & $\begin{array}{r}15.274 \\
7 \\
\end{array}$ & 0.8 & 1.1741 & 1.0 & 0.1301 & 0.6 & 0.63 & 788.2 & 4.7 & 788.5 & 5.5 & 789.4 & 16.3 & 788.2 & 4.7 & 99.9 \\
\hline PE-90 & 117 & 37415 & 2.2 & $\begin{array}{r}15.249 \\
8 \\
\end{array}$ & 1.5 & 1.2411 & 2.0 & 0.1373 & 1.3 & 0.64 & 829.2 & 9.8 & 819.4 & 11.0 & 792.8 & 31.5 & 829.2 & 9.8 & 104.6 \\
\hline PE-38 & 166 & 82275 & 0.9 & $\begin{array}{r}14.977 \\
0 \\
\end{array}$ & 1.3 & 1.2839 & 1.5 & 0.1395 & 0.9 & 0.57 & 841.6 & 7.0 & 838.6 & 8.8 & 830.6 & 26.2 & 841.6 & 7.0 & 101.3 \\
\hline PE-11 & 55 & 33828 & 0.3 & $\begin{array}{r}14.319 \\
7\end{array}$ & 4.4 & 1.4710 & 4.6 & 0.1528 & 1.3 & 0.28 & 916.5 & 11.0 & 918.5 & 27.9 & 923.5 & 91.1 & 923.5 & 91.1 & 99.2 \\
\hline
\end{tabular}




\begin{tabular}{|c|c|c|c|c|c|c|c|c|c|c|c|c|c|c|c|c|c|c|c|}
\hline Analysis & U & $206 \mathrm{~Pb}$ & $\begin{array}{c}\mathrm{U} / \mathrm{T} \\
\mathrm{h}\end{array}$ & $206 \mathrm{~Pb}^{*}$ & \pm & $207 \mathrm{~Pb}^{*}$ & \pm & $\underset{*}{206 \mathrm{~Pb}}$ & \pm & $\begin{array}{c}\text { erro } \\
\mathrm{r}\end{array}$ & $\underset{*}{206 \mathrm{~Pb}}$ & \pm & $\underset{*}{207 \mathrm{~Pb}}$ & \pm & $\underset{*}{206 \mathrm{~Pb}}$ & \pm & $\begin{array}{l}\text { Best } \\
\text { age }\end{array}$ & \pm & Conc \\
\hline & $\begin{array}{c}\text { (ppm } \\
\text { ) }\end{array}$ & $204 \mathrm{~Pb}$ & & $207 \mathrm{~Pb}^{*}$ & $(\%)$ & $235 \mathrm{U}^{*}$ & $(\%)$ & $238 \mathrm{U}$ & (\%) & corr. & $238 \mathrm{U}^{*}$ & (Ma) & $235 \mathrm{U}$ & (Ma) & $\underset{*}{207 \mathrm{~Pb}}$ & (Ma) & (Ma) & (Ma) & $(\%)$ \\
\hline PE-10 & 202 & $\begin{array}{r}23546 \\
0\end{array}$ & 1.4 & $\begin{array}{r}14.013 \\
4\end{array}$ & 0.8 & 1.6144 & 1.4 & 0.1641 & 1.2 & 0.84 & 979.4 & 10.7 & 975.8 & 8.8 & 967.7 & 15.4 & 967.7 & 15.4 & 101.2 \\
\hline PE-18 & 429 & $\begin{array}{r}26249 \\
4 \\
\end{array}$ & 2.2 & $\begin{array}{r}13.937 \\
9 \\
\end{array}$ & 0.2 & 1.5680 & 0.7 & 0.1585 & 0.7 & 0.95 & 948.4 & 5.8 & 957.6 & 4.3 & 978.7 & 4.5 & 978.7 & 4.5 & 96.9 \\
\hline PE-65 & 163 & $\begin{array}{r}13740 \\
6 \\
\end{array}$ & 2.2 & $\begin{array}{r}13.717 \\
2 \\
\end{array}$ & 1.1 & 1.7094 & 1.9 & 0.1701 & 1.5 & 0.80 & 1012.5 & 14.1 & 1012.1 & 12.1 & 1011.2 & 22.8 & 1011.2 & 22.8 & 100.1 \\
\hline PE-22 & 76 & 59854 & 3.4 & $\begin{array}{r}13.595 \\
4 \\
\end{array}$ & 1.8 & 1.8017 & 2.3 & 0.1777 & 1.4 & 0.60 & 1054.1 & 13.3 & 1046.1 & 15.0 & 1029.2 & 37.2 & 1029.2 & 37.2 & 102.4 \\
\hline PE-27 & 102 & 49454 & 4.3 & $\begin{array}{r}13.581 \\
5\end{array}$ & 1.5 & 1.7447 & 3.1 & 0.1719 & 2.7 & 0.87 & 1022.3 & 25.8 & 1025.2 & 20.2 & 1031.3 & 31.0 & 1031.3 & 31.0 & 99.1 \\
\hline PE-87 & 76 & $\begin{array}{r}17288 \\
9\end{array}$ & 2.0 & $\begin{array}{r}13.544 \\
7\end{array}$ & 1.7 & 1.7795 & 2.0 & 0.1748 & 1.1 & 0.56 & 1038.5 & 10.8 & 1038.0 & 13.1 & 1036.8 & 34.0 & 1036.8 & 34.0 & 100.2 \\
\hline PE-40 & 70 & 40980 & 1.0 & $\begin{array}{r}13.476 \\
8 \\
\end{array}$ & 3.0 & 1.7929 & 3.3 & 0.1752 & 1.2 & 0.38 & 1040.9 & 11.9 & 1042.9 & 21.4 & 1047.0 & 61.3 & 1047.0 & 61.3 & 99.4 \\
\hline PE-85 & 145 & 86386 & 2.1 & $\begin{array}{r}13.342 \\
6\end{array}$ & 0.9 & 1.9275 & 1.1 & 0.1865 & 0.7 & 0.62 & 1102.5 & 6.9 & 1090.7 & 7.3 & 1067.1 & 17.2 & 1067.1 & 17.2 & 103.3 \\
\hline PE-98 & 93 & $\begin{array}{r}10237 \\
8\end{array}$ & 2.7 & $\begin{array}{r}12.847 \\
6\end{array}$ & 1.7 & 2.1042 & 2.0 & 0.1961 & 1.0 & 0.50 & 1154.2 & 10.3 & 1150.2 & 13.6 & 1142.7 & 34.1 & 1142.7 & 34.1 & 101.0 \\
\hline PE-2 & 130 & 68126 & 1.5 & $\begin{array}{r}12.620 \\
4 \\
\end{array}$ & 0.9 & 2.1653 & 1.6 & 0.1982 & 1.3 & 0.81 & 1165.6 & 14.2 & 1170.0 & 11.4 & 1178.1 & 18.8 & 1178.1 & 18.8 & 98.9 \\
\hline PE-1 & 71 & 3561 & 1.0 & $\begin{array}{r}12.569 \\
7 \\
\end{array}$ & 2.5 & 2.1273 & 3.0 & 0.1939 & 1.8 & 0.58 & 1142.6 & 18.4 & 1157.7 & 20.9 & 1186.0 & 48.7 & 1186.0 & 48.7 & 96.3 \\
\hline PE-15 & 91 & 96461 & 1.8 & $\begin{array}{r}12.501 \\
2\end{array}$ & 1.8 & 2.2152 & 1.9 & 0.2008 & 0.5 & 0.28 & 1179.8 & 5.9 & 1185.8 & 13.5 & 1196.8 & 36.5 & 1196.8 & 36.5 & 98.6 \\
\hline PE-100 & 70 & 37320 & 1.9 & $\begin{array}{r}12.455 \\
6\end{array}$ & 1.8 & 2.2239 & 3.0 & 0.2009 & 2.4 & 0.80 & 1180.2 & 25.7 & 1188.6 & 21.0 & 1204.0 & 35.7 & 1204.0 & 35.7 & 98.0 \\
\hline PE-49 & 215 & $\begin{array}{r}11540 \\
8 \\
\end{array}$ & 2.7 & $\begin{array}{r}12.390 \\
4 \\
\end{array}$ & 1.0 & 2.2822 & 1.2 & 0.2051 & 0.7 & 0.56 & 1202.6 & 7.7 & 1206.8 & 8.8 & 1214.3 & 20.2 & 1214.3 & 20.2 & 99.0 \\
\hline PE-69 & 442 & $\begin{array}{r}23658 \\
9 \\
\end{array}$ & 2.5 & $\begin{array}{r}12.347 \\
2 \\
\end{array}$ & 0.3 & 2.3192 & 1.3 & 0.2077 & 1.2 & 0.97 & 1216.5 & 13.5 & 1218.2 & 8.9 & 1221.2 & 5.9 & 1221.2 & 5.9 & 99.6 \\
\hline PE-62 & 326 & $\begin{array}{r}16986 \\
9 \\
\end{array}$ & 3.1 & $\begin{array}{r}12.337 \\
8 \\
\end{array}$ & 0.4 & 2.2791 & 1.0 & 0.2039 & 0.9 & 0.92 & 1196.4 & 10.1 & 1205.8 & 7.1 & 1222.7 & 8.0 & 1222.7 & 8.0 & 97.9 \\
\hline PE-3 & 263 & $\begin{array}{r}13121 \\
1\end{array}$ & 3.8 & $\begin{array}{r}12.285 \\
1\end{array}$ & 0.4 & 2.3434 & 0.9 & 0.2088 & 0.8 & 0.87 & 1222.4 & 8.5 & 1225.6 & 6.2 & 1231.1 & 8.5 & 1231.1 & 8.5 & 99.3 \\
\hline PE-80 & 193 & $\begin{array}{r}19663 \\
9\end{array}$ & 3.4 & $\begin{array}{r}12.215 \\
0\end{array}$ & 0.5 & 2.3900 & 1.0 & 0.2117 & 0.8 & 0.87 & 1238.0 & 9.4 & 1239.6 & 6.9 & 1242.3 & 9.5 & 1242.3 & 9.5 & 99.7 \\
\hline PE-76 & 59 & 35396 & 1.2 & $\begin{array}{r}11.948 \\
9 \\
\end{array}$ & 2.2 & 2.6085 & 2.4 & 0.2261 & 1.0 & 0.43 & 1313.8 & 12.2 & 1303.0 & 17.6 & 1285.3 & 42.1 & 1285.3 & 42.1 & 102.2 \\
\hline PE-31 & 668 & $\begin{array}{r}51047 \\
0 \\
\end{array}$ & 2.5 & $\begin{array}{r}10.421 \\
7\end{array}$ & 0.2 & 3.6504 & 2.5 & 0.2759 & 2.5 & 1.00 & 1570.8 & 34.8 & 1560.6 & 20.0 & 1546.8 & 4.5 & 1546.8 & 4.5 & 101.5 \\
\hline PE-35 & 344 & $\begin{array}{r}42361 \\
0\end{array}$ & 2.0 & 9.3526 & 0.2 & 4.6335 & 1.1 & 0.3143 & 1.1 & 0.99 & 1761.8 & 17.4 & 1755.3 & 9.6 & 1747.6 & 3.5 & 1747.6 & 3.5 & 100.8 \\
\hline PE-67 & 69 & $\begin{array}{r}15988 \\
9 \\
\end{array}$ & 1.2 & 9.1112 & 0.5 & 4.8261 & 0.9 & 0.3189 & 0.7 & 0.82 & 1784.4 & 11.4 & 1789.5 & 7.5 & 1795.3 & 9.2 & 1795.3 & 9.2 & 99.4 \\
\hline PE-33 & 16 & 15989 & 0.1 & 8.7923 & 3.2 & 5.2037 & 4.5 & 0.3318 & 3.2 & 0.72 & 1847.3 & 52.0 & 1853.2 & 38.5 & 1859.9 & 57.0 & 1859.9 & 57.0 & 99.3 \\
\hline PE-16 & 268 & $\begin{array}{r}21922 \\
5\end{array}$ & 1.2 & 8.6889 & 0.2 & 5.3250 & 0.8 & 0.3356 & 0.8 & 0.96 & 1865.3 & 13.2 & 1872.9 & 7.2 & 1881.3 & 4.1 & 1881.3 & 4.1 & 99.2 \\
\hline PE-13 & 102 & $\begin{array}{r}16402 \\
2 \\
\end{array}$ & 0.9 & 8.6732 & 0.7 & 5.3116 & 1.0 & 0.3341 & 0.8 & 0.76 & 1858.3 & 12.5 & 1870.7 & 8.6 & 1884.5 & 11.7 & 1884.5 & 11.7 & 98.6 \\
\hline PE-89 & 80 & 57093 & 1.1 & 8.1504 & 0.6 & 6.2530 & 0.9 & 0.3696 & 0.7 & 0.75 & 2027.7 & 11.7 & 2011.9 & 7.9 & 1995.7 & 10.6 & 1995.7 & 10.6 & 101.6 \\
\hline PE-28 & 31 & 37503 & 0.7 & 7.9959 & 1.0 & 6.4478 & 1.4 & 0.3739 & 1.0 & 0.72 & 2047.8 & 17.6 & 2038.8 & 12.2 & 2029.7 & 17.0 & 2029.7 & 17.0 & 100.9 \\
\hline PE-37 & 145 & 45716 & 1.1 & 7.9775 & 0.4 & 6.4327 & 0.8 & 0.3722 & 0.7 & 0.89 & 2039.7 & 12.0 & 2036.7 & 6.8 & 2033.8 & 6.2 & 2033.8 & 6.2 & 100.3 \\
\hline PE-99 & 89 & 90491 & 1.9 & 7.8389 & 0.9 & 6.3689 & 2.4 & 0.3621 & 2.2 & 0.93 & 1992.1 & 38.2 & 2028.0 & 21.0 & 2064.7 & 15.5 & 2064.7 & 15.5 & 96.5 \\
\hline PE-41 & 58 & 53738 & 1.7 & 7.7564 & 0.9 & 6.8400 & 1.2 & 0.3848 & 0.8 & 0.67 & 2098.6 & 14.5 & 2090.9 & 10.7 & 2083.3 & 15.8 & 2083.3 & 15.8 & 100.7 \\
\hline PE-72 & 101 & $\begin{array}{r}16292 \\
3 \\
\end{array}$ & 2.8 & 7.6989 & 0.5 & 6.3506 & 1.4 & 0.3546 & 1.3 & 0.94 & 1956.5 & 21.8 & 2025.5 & 12.0 & 2096.4 & 8.0 & 2096.4 & 8.0 & 93.3 \\
\hline PE-7 & 282 & $\begin{array}{r}39039 \\
0 \\
\end{array}$ & 2.1 & 7.2872 & 0.5 & 7.7485 & 3.1 & 0.4095 & 3.0 & 0.99 & 2212.7 & 56.8 & 2202.2 & 27.7 & 2192.5 & 9.1 & 2192.5 & 9.1 & 100.9 \\
\hline PE-92 & 70 & 12226 & 1.1 & 7.2187 & 0.9 & 7.5501 & 8.6 & 0.3953 & 8.5 & 0.99 & 2147.3 & $\begin{array}{r}155 . \\
4\end{array}$ & 2179.0 & 76.8 & 2208.9 & 14.9 & 2208.9 & 14.9 & 97.2 \\
\hline PE-86 & 33 & 58693 & 0.5 & 6.6184 & 0.8 & 8.4925 & 1.5 & 0.4076 & 1.3 & 0.86 & 2204.2 & 24.6 & 2285.1 & 14.0 & 2358.3 & 13.6 & 2358.3 & 13.6 & 93.5 \\
\hline PE-96 & 209 & $\begin{array}{r}29746 \\
7\end{array}$ & 1.5 & 5.1854 & 0.2 & $\begin{array}{r}13.950 \\
1\end{array}$ & 1.7 & 0.5246 & 1.7 & 0.99 & 2718.8 & 37.9 & 2746.3 & 16.3 & 2766.6 & 3.7 & 2766.6 & 3.7 & 98.3 \\
\hline
\end{tabular}

\begin{tabular}{|c|c|c|c|c|c|c|c|c|c|c|c|c|c|c|c|c|c|c|c|}
\hline Analysis & U & $206 \mathrm{~Pb}$ & $\begin{array}{c}\mathrm{U} / \mathrm{T} \\
\mathrm{h}\end{array}$ & $206 \mathrm{~Pb}^{*}$ & \pm & $207 \mathrm{~Pb}^{*}$ & \pm & $\underset{*}{206 \mathrm{~Pb}}$ & \pm & $\begin{array}{c}\text { erro } \\
\mathrm{r}\end{array}$ & $\underset{*}{206 \mathrm{~Pb}}$ & \pm & $\underset{*}{207 \mathrm{~Pb}}$ & \pm & $\underset{*}{206 \mathrm{~Pb}}$ & \pm & $\begin{array}{l}\text { Best } \\
\text { age }\end{array}$ & \pm & Conc \\
\hline & (ppm & $204 \mathrm{~Pb}$ & & $207 \mathrm{~Pb}^{*}$ & $(\%)$ & $235 \mathrm{U}^{*}$ & (\%) & $238 \mathrm{U}$ & (\%) & corr. & $238 \mathrm{U}^{*}$ & (Ma) & $235 \mathrm{U}$ & (Ma) & $\underset{*}{207 \mathrm{~Pb}}$ & (Ma) & (Ma) & (Ma) & (\%) \\
\hline DD-71 & 41 & 7168 & 0.6 & $\begin{array}{r}22.886 \\
4\end{array}$ & $\begin{array}{r}39 . \\
2\end{array}$ & 0.2728 & $\begin{array}{r}39 . \\
3 \\
\end{array}$ & 0.0453 & 3.6 & 0.09 & 285.5 & 10.0 & 244.9 & 85.8 & -127.9 & $\begin{array}{r}1001 . \\
0 \\
\end{array}$ & 285.5 & 10.0 & NA \\
\hline
\end{tabular}




\begin{tabular}{|c|c|c|c|c|c|c|c|c|c|c|c|c|c|c|c|c|c|c|c|}
\hline Analysis & U & $206 \mathrm{~Pb}$ & $\begin{array}{c}\mathrm{U} / \mathrm{T} \\
\mathrm{h}\end{array}$ & $206 \mathrm{~Pb}^{*}$ & \pm & $207 \mathrm{~Pb}^{*}$ & \pm & $\underset{*}{206 \mathrm{~Pb}}$ & \pm & $\begin{array}{c}\text { erro } \\
\mathrm{r}\end{array}$ & $\underset{*}{206 \mathrm{~Pb}}$ & \pm & $\underset{*}{207 \mathrm{~Pb}}$ & \pm & $\underset{*}{206 \mathrm{~Pb}}$ & \pm & $\begin{array}{l}\text { Best } \\
\text { age }\end{array}$ & \pm & Conc \\
\hline & $\begin{array}{c}\text { (ppm } \\
\text { ) }\end{array}$ & $204 \mathrm{~Pb}$ & & $207 \mathrm{~Pb}^{*}$ & $(\%)$ & $235 \mathrm{U}^{*}$ & $(\%)$ & $238 \mathrm{U}$ & $(\%)$ & corr. & $238 \mathrm{U}^{*}$ & (Ma) & $235 \mathrm{U}$ & (Ma) & $\underset{*}{207 \mathrm{~Pb}}$ & (Ma) & (Ma) & (Ma) & $(\%)$ \\
\hline DD-89 & 128 & 17515 & 0.6 & $\begin{array}{r}19.354 \\
6\end{array}$ & 8.4 & 0.3402 & 8.8 & 0.0478 & 2.6 & 0.30 & 300.7 & 7.7 & 297.3 & 22.7 & 270.7 & 193.2 & 300.7 & 7.7 & NA \\
\hline DD-84 & 192 & 36528 & 0.6 & $\begin{array}{r}19.336 \\
6 \\
\end{array}$ & 4.0 & 0.3412 & 4.1 & 0.0478 & 1.0 & 0.23 & 301.3 & 2.8 & 298.1 & 10.6 & 272.8 & 91.2 & 301.3 & 2.8 & NA \\
\hline DD-29 & 876 & $\begin{array}{r}21641 \\
4 \\
\end{array}$ & 1.6 & $\begin{array}{r}18.951 \\
0 \\
\end{array}$ & 0.7 & 0.3579 & 1.3 & 0.0492 & 1.1 & 0.87 & 309.6 & 3.4 & 310.7 & 3.5 & 318.8 & 15.0 & 309.6 & 3.4 & NA \\
\hline DD-98 & 93 & 2102 & 1.3 & $\begin{array}{r}18.269 \\
6 \\
\end{array}$ & 9.3 & 0.3722 & 9.4 & 0.0493 & 1.6 & 0.17 & 310.4 & 4.7 & 321.3 & 26.0 & 401.4 & 208.5 & 310.4 & 4.7 & NA \\
\hline DD-28 & 234 & 48520 & 2.2 & $\begin{array}{r}17.708 \\
6\end{array}$ & 2.5 & 0.4480 & 3.5 & 0.0575 & 2.4 & 0.69 & 360.6 & 8.4 & 375.9 & 10.9 & 470.9 & 55.4 & 360.6 & 8.4 & NA \\
\hline DD-88 & 987 & 7196 & 0.7 & $\begin{array}{r}17.131 \\
1 \\
\end{array}$ & 0.5 & 0.4761 & 3.2 & 0.0591 & 3.1 & 0.99 & 370.4 & 11.2 & 395.4 & 10.3 & 543.8 & 10.1 & 370.4 & 11.2 & NA \\
\hline DD-10 & 213 & 37680 & 0.6 & $\begin{array}{r}17.944 \\
4 \\
\end{array}$ & 3.2 & 0.4972 & 3.3 & 0.0647 & 0.8 & 0.24 & 404.2 & 3.1 & 409.8 & 11.1 & 441.5 & 70.9 & 404.2 & 3.1 & 91.6 \\
\hline DD-83 & 351 & 92505 & 2.3 & $\begin{array}{r}17.988 \\
1\end{array}$ & 1.1 & 0.5109 & 1.7 & 0.0667 & 1.2 & 0.75 & 415.9 & 5.0 & 419.0 & 5.7 & 436.1 & 24.7 & 415.9 & 5.0 & 95.4 \\
\hline DD-49 & 224 & 45096 & 2.6 & $\begin{array}{r}18.067 \\
8 \\
\end{array}$ & 3.4 & 0.5197 & 3.5 & 0.0681 & 1.1 & 0.30 & 424.7 & 4.4 & 425.0 & 12.3 & 426.3 & 75.4 & 424.7 & 4.4 & 99.6 \\
\hline DD-11 & 320 & 84454 & 0.8 & $\begin{array}{r}17.940 \\
1 \\
\end{array}$ & 1.7 & 0.5298 & 2.3 & 0.0689 & 1.5 & 0.66 & 429.7 & 6.2 & 431.6 & 7.9 & 442.1 & 38.0 & 429.7 & 6.2 & 97.2 \\
\hline DD-39 & 152 & 30750 & 1.6 & $\begin{array}{r}17.784 \\
3 \\
\end{array}$ & 3.1 & 0.5531 & 3.5 & 0.0713 & 1.7 & 0.47 & 444.2 & 7.1 & 447.0 & 12.8 & 461.4 & 69.4 & 444.2 & 7.1 & 96.3 \\
\hline DD-1 & 236 & 63026 & 1.3 & $\begin{array}{r}17.584 \\
5\end{array}$ & 1.8 & 0.5924 & 2.8 & 0.0756 & 2.1 & 0.76 & 469.5 & 9.6 & 472.4 & 10.5 & 486.4 & 39.4 & 469.5 & 9.6 & 96.5 \\
\hline DD-58 & 811 & 42897 & 1.0 & $\begin{array}{r}16.565 \\
9\end{array}$ & 0.9 & 0.6566 & 3.9 & 0.0789 & 3.8 & 0.97 & 489.5 & 17.8 & 512.6 & 15.6 & 616.7 & 19.1 & 489.5 & 17.8 & 79.4 \\
\hline DD-86 & 281 & 90647 & 3.0 & $\begin{array}{r}17.023 \\
4 \\
\end{array}$ & 1.8 & 0.6589 & 2.1 & 0.0814 & 0.9 & 0.46 & 504.2 & 4.6 & 514.0 & 8.3 & 557.6 & 39.8 & 504.2 & 4.6 & 90.4 \\
\hline DD-73 & 104 & 44675 & 1.1 & $\begin{array}{r}13.820 \\
5 \\
\end{array}$ & 2.7 & 0.8419 & $\begin{array}{r}10 . \\
3\end{array}$ & 0.0844 & $\begin{array}{r}10 . \\
0\end{array}$ & 0.97 & 522.3 & 50.0 & 620.2 & 48.0 & 996.0 & 54.9 & 522.3 & 50.0 & 52.4 \\
\hline DD-14 & 195 & 96557 & 4.7 & $\begin{array}{r}17.013 \\
3 \\
\end{array}$ & 2.5 & 0.6988 & 3.2 & 0.0862 & 2.0 & 0.62 & 533.2 & 10.1 & 538.1 & 13.5 & 558.8 & 55.4 & 533.2 & 10.1 & 95.4 \\
\hline DD-33 & 733 & $\begin{array}{r}31310 \\
4\end{array}$ & 1.9 & $\begin{array}{r}16.988 \\
8\end{array}$ & 0.6 & 0.7037 & 2.9 & 0.0867 & 2.8 & 0.98 & 536.0 & 14.5 & 541.0 & 12.1 & 562.0 & 14.0 & 536.0 & 14.5 & 95.4 \\
\hline DD-75 & 80 & 19454 & 0.6 & $\begin{array}{r}16.633 \\
1\end{array}$ & 4.9 & 0.7211 & 8.1 & 0.0870 & 6.5 & 0.80 & 537.7 & 33.6 & 551.3 & 34.7 & 607.9 & 105.6 & 537.7 & 33.6 & 88.5 \\
\hline DD-3 & 201 & $\begin{array}{r}13330 \\
2 \\
\end{array}$ & 5.5 & $\begin{array}{r}17.282 \\
9 \\
\end{array}$ & 1.7 & 0.6959 & 2.0 & 0.0872 & 1.1 & 0.52 & 539.1 & 5.4 & 536.3 & 8.3 & 524.5 & 37.4 & 539.1 & 5.4 & 102.8 \\
\hline DD-74 & 393 & $\begin{array}{r}23596 \\
2\end{array}$ & 1.3 & $\begin{array}{r}16.984 \\
2\end{array}$ & 1.2 & 0.7111 & 2.4 & 0.0876 & 2.1 & 0.88 & 541.3 & 11.1 & 545.4 & 10.3 & 562.6 & 25.5 & 541.3 & 11.1 & 96.2 \\
\hline DD-79 & 70 & 28148 & 0.5 & $\begin{array}{r}16.671 \\
3\end{array}$ & 5.0 & 0.7279 & 5.2 & 0.0880 & 1.2 & 0.23 & 543.8 & 6.1 & 555.3 & 22.1 & 603.0 & 109.1 & 543.8 & 6.1 & 90.2 \\
\hline DD-46 & 461 & $\begin{array}{r}11431 \\
5\end{array}$ & 0.7 & $\begin{array}{r}17.163 \\
1\end{array}$ & 1.1 & 0.7077 & 1.4 & 0.0881 & 0.8 & 0.60 & 544.2 & 4.4 & 543.4 & 5.9 & 539.7 & 24.6 & 544.2 & 4.4 & 100.8 \\
\hline DD-69 & 153 & 73244 & 1.1 & $\begin{array}{r}17.120 \\
1\end{array}$ & 2.1 & 0.7147 & 2.5 & 0.0887 & 1.4 & 0.54 & 548.1 & 7.2 & 547.5 & 10.8 & 545.2 & 46.9 & 548.1 & 7.2 & 100.5 \\
\hline DD-34 & 382 & 80902 & 0.8 & $\begin{array}{r}17.056 \\
0\end{array}$ & 0.9 & 0.7329 & 2.1 & 0.0907 & 1.9 & 0.89 & 559.5 & 10.0 & 558.3 & 9.0 & 553.4 & 20.6 & 559.5 & 10.0 & 101.1 \\
\hline DD-70 & 89 & 33089 & 0.9 & $\begin{array}{r}16.756 \\
0 \\
\end{array}$ & 4.2 & 0.7507 & 4.9 & 0.0912 & 2.5 & 0.51 & 562.8 & 13.3 & 568.7 & 21.2 & 592.0 & 91.1 & 562.8 & 13.3 & 95.1 \\
\hline DD-50 & 148 & 31900 & 1.7 & $\begin{array}{r}17.364 \\
5\end{array}$ & 2.2 & 0.7256 & 3.0 & 0.0914 & 2.1 & 0.68 & 563.7 & 11.2 & 554.0 & 13.0 & 514.1 & 48.7 & 563.7 & 11.2 & 109.6 \\
\hline DD-76 & 52 & 15358 & 1.1 & $\begin{array}{r}16.378 \\
5\end{array}$ & 5.7 & 0.7820 & 6.0 & 0.0929 & 1.8 & 0.29 & 572.6 & 9.6 & 586.6 & 26.6 & 641.2 & 122.8 & 572.6 & 9.6 & 89.3 \\
\hline DD-64 & 148 & 49837 & 1.5 & $\begin{array}{r}16.706 \\
4\end{array}$ & 3.1 & 0.7680 & 3.7 & 0.0931 & 2.1 & 0.55 & 573.6 & 11.3 & 578.6 & 16.4 & 598.4 & 67.2 & 573.6 & 11.3 & 95.9 \\
\hline DD-56 & 511 & $\begin{array}{r}14782 \\
7\end{array}$ & 0.6 & $\begin{array}{r}16.823 \\
1\end{array}$ & 0.6 & 0.7740 & 1.5 & 0.0944 & 1.4 & 0.91 & 581.8 & 7.6 & 582.1 & 6.7 & 583.3 & 13.8 & 581.8 & 7.6 & 99.7 \\
\hline DD-42 & 29 & 13768 & 1.1 & $\begin{array}{r}17.452 \\
4\end{array}$ & $\begin{array}{r}10 . \\
8\end{array}$ & 0.7596 & $\begin{array}{r}11 . \\
1\end{array}$ & 0.0962 & 2.4 & 0.22 & 591.8 & 13.7 & 573.8 & 48.8 & 503.0 & 239.3 & 591.8 & 13.7 & 117.6 \\
\hline DD-37 & 98 & 18920 & 3.2 & $\begin{array}{r}16.685 \\
1\end{array}$ & 4.5 & 0.7952 & 4.9 & 0.0962 & 1.8 & 0.38 & 592.2 & 10.4 & 594.1 & 21.8 & 601.2 & 97.2 & 592.2 & 10.4 & 98.5 \\
\hline DD-55 & 226 & 57045 & 1.2 & $\begin{array}{r}16.811 \\
7\end{array}$ & 1.6 & 0.7967 & 2.4 & 0.0971 & 1.8 & 0.76 & 597.6 & 10.4 & 595.0 & 10.8 & 584.8 & 34.1 & 597.6 & 10.4 & 102.2 \\
\hline DD-66 & 289 & $\begin{array}{r}14597 \\
6\end{array}$ & 2.0 & $\begin{array}{r}16.585 \\
2\end{array}$ & 1.1 & 0.8086 & 1.9 & 0.0973 & 1.5 & 0.81 & 598.4 & 8.7 & 601.7 & 8.5 & 614.2 & 23.9 & 598.4 & 8.7 & 97.4 \\
\hline DD-81 & 110 & 38699 & 59.9 & $\begin{array}{r}16.391 \\
4\end{array}$ & 3.4 & 0.8210 & 3.5 & 0.0976 & 0.8 & 0.22 & 600.3 & 4.4 & 608.6 & 16.1 & 639.5 & 73.7 & 600.3 & 4.4 & 93.9 \\
\hline DD-96 & 176 & 58002 & 1.9 & $\begin{array}{r}16.879 \\
5\end{array}$ & 1.6 & 0.8027 & 1.7 & 0.0983 & 0.7 & 0.39 & 604.3 & 3.9 & 598.4 & 7.9 & 576.0 & 35.0 & 604.3 & 3.9 & 104.9 \\
\hline DD-43 & 150 & 42963 & 1.4 & $\begin{array}{r}16.572 \\
1\end{array}$ & 1.9 & 0.8182 & 2.3 & 0.0983 & 1.2 & 0.53 & 604.7 & 6.9 & 607.1 & 10.3 & 615.9 & 41.5 & 604.7 & 6.9 & 98.2 \\
\hline DD-67 & 255 & $\begin{array}{r}16515 \\
3\end{array}$ & 0.7 & $\begin{array}{r}16.436 \\
7\end{array}$ & 1.0 & 0.8393 & 2.9 & 0.1001 & 2.7 & 0.93 & 614.7 & 15.9 & 618.8 & 13.5 & 633.6 & 22.6 & 614.7 & 15.9 & 97.0 \\
\hline DD-8 & 274 & $\begin{array}{r}10651 \\
3\end{array}$ & 4.0 & $\begin{array}{r}16.578 \\
3\end{array}$ & 1.1 & 0.8336 & 1.3 & 0.1002 & 0.7 & 0.51 & 615.8 & 4.0 & 615.6 & 6.1 & 615.0 & 24.7 & 615.8 & 4.0 & 100.1 \\
\hline DD-95 & 165 & 63311 & 0.8 & $\begin{array}{r}16.718 \\
5\end{array}$ & 1.0 & 0.8363 & 1.3 & 0.1014 & 0.9 & 0.63 & 622.6 & 5.0 & 617.1 & 6.2 & 596.9 & 22.5 & 622.6 & 5.0 & 104.3 \\
\hline
\end{tabular}




\begin{tabular}{|c|c|c|c|c|c|c|c|c|c|c|c|c|c|c|c|c|c|c|c|}
\hline Analysis & U & $206 \mathrm{~Pb}$ & $\begin{array}{c}\mathrm{U} / \mathrm{T} \\
\mathrm{h}\end{array}$ & $206 \mathrm{~Pb}^{*}$ & \pm & $207 \mathrm{~Pb}^{*}$ & \pm & $\underset{*}{206 \mathrm{~Pb}}$ & \pm & $\begin{array}{c}\text { erro } \\
\mathrm{r}\end{array}$ & $\underset{*}{206 \mathrm{~Pb}}$ & \pm & $\underset{*}{207 \mathrm{~Pb}}$ & \pm & $\underset{*}{206 \mathrm{~Pb}}$ & \pm & $\begin{array}{l}\text { Best } \\
\text { age }\end{array}$ & \pm & Conc \\
\hline & $\begin{array}{c}\text { (ppm } \\
\text { ) }\end{array}$ & $204 \mathrm{~Pb}$ & & $207 \mathrm{~Pb}^{*}$ & $(\%)$ & $235 \mathrm{U}^{*}$ & $(\%)$ & $238 \mathrm{U}$ & (\%) & corr. & $238 \mathrm{U}^{*}$ & (Ma) & $235 \mathrm{U}$ & (Ma) & $\underset{*}{207 \mathrm{~Pb}}$ & (Ma) & (Ma) & (Ma) & $(\%)$ \\
\hline DD-62 & 48 & 17963 & 1.4 & $\begin{array}{r}16.508 \\
8\end{array}$ & 6.7 & 0.8583 & 7.1 & 0.1028 & 2.4 & 0.34 & 630.6 & 14.2 & 629.2 & 33.2 & 624.1 & 143.7 & 630.6 & 14.2 & 101.0 \\
\hline DD-23 & 77 & 48850 & 0.6 & $\begin{array}{r}16.132 \\
3 \\
\end{array}$ & 3.9 & 0.9008 & 4.0 & 0.1054 & 0.9 & 0.24 & 646.0 & 5.8 & 652.2 & 19.2 & 673.7 & 83.0 & 646.0 & 5.8 & 95.9 \\
\hline DD-22 & 110 & 24128 & 1.5 & $\begin{array}{r}16.263 \\
2 \\
\end{array}$ & 2.4 & 0.8981 & 3.0 & 0.1059 & 1.7 & 0.57 & 649.1 & 10.3 & 650.7 & 14.2 & 656.4 & 52.5 & 649.1 & 10.3 & 98.9 \\
\hline DD-19 & 240 & 78437 & 3.3 & $\begin{array}{r}15.415 \\
8 \\
\end{array}$ & 1.5 & 1.0092 & 4.4 & 0.1128 & 4.1 & 0.94 & 689.2 & 27.0 & 708.5 & 22.4 & 770.1 & 31.0 & 689.2 & 27.0 & 89.5 \\
\hline DD-52 & 32 & 9639 & 1.6 & $\begin{array}{r}14.984 \\
3\end{array}$ & 7.8 & 1.0505 & 8.2 & 0.1142 & 2.5 & 0.30 & 696.9 & 16.4 & 729.1 & 42.8 & 829.6 & 163.6 & 696.9 & 16.4 & 84.0 \\
\hline DD-85 & 174 & $\begin{array}{r}15929 \\
9 \\
\end{array}$ & 0.8 & $\begin{array}{r}15.588 \\
4 \\
\end{array}$ & 1.4 & 1.1052 & 1.7 & 0.1250 & 1.0 & 0.57 & 759.0 & 6.9 & 755.9 & 9.1 & 746.6 & 29.7 & 759.0 & 6.9 & 101.7 \\
\hline DD-45 & 990 & 27550 & 7.3 & $\begin{array}{r}14.463 \\
6 \\
\end{array}$ & 0.5 & 1.2046 & 0.9 & 0.1264 & 0.8 & 0.81 & 767.1 & 5.4 & 802.7 & 5.2 & 902.9 & 11.3 & 767.1 & 5.4 & 85.0 \\
\hline DD-78 & 29 & 50943 & 2.2 & $\begin{array}{r}13.786 \\
2\end{array}$ & 5.7 & 1.6225 & 6.2 & 0.1622 & 2.4 & 0.39 & 969.2 & 21.6 & 979.0 & 38.9 & 1001.0 & 116.1 & 1001.0 & $\begin{array}{r}116 . \\
1\end{array}$ & 96.8 \\
\hline DD-20 & 778 & 40302 & 23.1 & $\begin{array}{r}13.747 \\
8 \\
\end{array}$ & 2.2 & 1.4859 & 2.9 & 0.1482 & 1.9 & 0.66 & 890.6 & 15.7 & 924.6 & 17.5 & 1006.7 & 44.1 & 1006.7 & 44.1 & 88.5 \\
\hline DD-44 & 162 & 79842 & 1.7 & $\begin{array}{r}13.637 \\
2 \\
\end{array}$ & 1.0 & 1.8215 & 1.3 & 0.1802 & 0.9 & 0.65 & 1067.8 & 8.4 & 1053.2 & 8.6 & 1023.0 & 20.0 & 1023.0 & 20.0 & 104.4 \\
\hline DD-59 & 120 & 49864 & 2.4 & $\begin{array}{r}13.615 \\
1 \\
\end{array}$ & 1.2 & 1.7194 & 2.7 & 0.1698 & 2.4 & 0.89 & 1010.9 & 22.1 & 1015.8 & 17.1 & 1026.3 & 24.8 & 1026.3 & 24.8 & 98.5 \\
\hline DD-5 & 161 & 42846 & 2.5 & $\begin{array}{r}13.555 \\
1\end{array}$ & 0.8 & 1.7117 & 1.3 & 0.1683 & 1.0 & 0.78 & 1002.6 & 9.1 & 1012.9 & 8.0 & 1035.3 & 15.9 & 1035.3 & 15.9 & 96.8 \\
\hline DD-47 & 84 & 32932 & 1.3 & $\begin{array}{r}13.485 \\
7 \\
\end{array}$ & 1.9 & 1.8125 & 2.6 & 0.1773 & 1.7 & 0.65 & 1052.1 & 16.2 & 1050.0 & 16.7 & 1045.6 & 38.9 & 1045.6 & 38.9 & 100.6 \\
\hline DD-15 & 769 & $\begin{array}{r}53598 \\
2 \\
\end{array}$ & 2.7 & $\begin{array}{r}13.482 \\
2 \\
\end{array}$ & 0.2 & 1.7894 & 1.0 & 0.1750 & 1.0 & 0.98 & 1039.4 & 9.3 & 1041.6 & 6.4 & 1046.2 & 3.6 & 1046.2 & 3.6 & 99.4 \\
\hline DD-7 & 71 & 45403 & 1.7 & $\begin{array}{r}13.350 \\
6 \\
\end{array}$ & 2.1 & 1.9042 & 2.4 & 0.1844 & 1.2 & 0.48 & 1090.9 & 11.6 & 1082.6 & 16.0 & 1065.9 & 42.3 & 1065.9 & 42.3 & 102.3 \\
\hline DD-65 & 143 & 76138 & 1.7 & $\begin{array}{r}13.240 \\
5 \\
\end{array}$ & 0.8 & 1.8946 & 1.7 & 0.1819 & 1.5 & 0.89 & 1077.6 & 15.1 & 1079.2 & 11.3 & 1082.5 & 15.5 & 1082.5 & 15.5 & 99.5 \\
\hline DD-91 & 43 & 53625 & 2.1 & $\begin{array}{r}13.069 \\
4\end{array}$ & 2.1 & 1.9951 & 2.8 & 0.1891 & 1.9 & 0.67 & 1116.6 & 19.5 & 1113.9 & 19.3 & 1108.5 & 42.2 & 1108.5 & 42.2 & 100.7 \\
\hline DD-4 & 55 & 19301 & 1.4 & $\begin{array}{r}12.687 \\
8\end{array}$ & 3.0 & 2.1362 & 3.4 & 0.1966 & 1.6 & 0.46 & 1156.9 & 16.6 & 1160.6 & 23.6 & 1167.5 & 59.9 & 1167.5 & 59.9 & 99.1 \\
\hline DD-36 & 143 & 39020 & 3.6 & $\begin{array}{r}12.616 \\
8 \\
\end{array}$ & 1.5 & 2.0136 & 2.2 & 0.1843 & 1.6 & 0.72 & 1090.2 & 15.8 & 1120.1 & 14.9 & 1178.6 & 30.3 & 1178.6 & 30.3 & 92.5 \\
\hline DD-17 & 343 & $\begin{array}{r}13959 \\
7\end{array}$ & 4.1 & $\begin{array}{r}12.613 \\
6\end{array}$ & 0.4 & 2.1709 & 1.2 & 0.1986 & 1.1 & 0.93 & 1167.8 & 11.6 & 1171.8 & 8.1 & 1179.1 & 8.5 & 1179.1 & 8.5 & 99.0 \\
\hline DD-38 & 69 & 32181 & 2.0 & $\begin{array}{r}12.463 \\
2\end{array}$ & 1.4 & 2.3202 & 2.6 & 0.2097 & 2.1 & 0.83 & 1227.4 & 23.8 & 1218.5 & 18.1 & 1202.8 & 27.8 & 1202.8 & 27.8 & 102.0 \\
\hline DD-25 & 160 & $\begin{array}{r}11939 \\
2 \\
\end{array}$ & 2.0 & $\begin{array}{r}12.452 \\
3 \\
\end{array}$ & 0.9 & 2.2297 & 2.5 & 0.2014 & 2.4 & 0.94 & 1182.7 & 25.6 & 1190.4 & 17.7 & 1204.5 & 17.5 & 1204.5 & 17.5 & 98.2 \\
\hline DD-99 & 140 & 80858 & 1.6 & $\begin{array}{r}12.312 \\
9\end{array}$ & 1.0 & 2.3817 & 1.3 & 0.2127 & 0.8 & 0.63 & 1243.1 & 9.5 & 1237.1 & 9.5 & 1226.6 & 20.2 & 1226.6 & 20.2 & 101.3 \\
\hline DD-31 & 356 & 18366 & 1.7 & $\begin{array}{r}12.009 \\
5\end{array}$ & 1.2 & 2.0939 & 2.2 & 0.1824 & 1.9 & 0.85 & 1080.0 & 18.8 & 1146.8 & 15.4 & 1275.5 & 23.1 & 1275.5 & 23.1 & 84.7 \\
\hline DD-48 & 46 & 48195 & 1.7 & $\begin{array}{r}11.960 \\
8\end{array}$ & 3.7 & 2.4681 & 8.6 & 0.2141 & 7.7 & 0.90 & 1250.6 & 88.0 & 1262.7 & 62.1 & 1283.4 & 72.1 & 1283.4 & 72.1 & 97.4 \\
\hline DD-97 & 28 & 92310 & 0.9 & $\begin{array}{r}11.822 \\
3\end{array}$ & 3.6 & 2.6638 & 3.8 & 0.2284 & 1.2 & 0.31 & 1326.1 & 14.2 & 1318.5 & 28.3 & 1306.0 & 70.8 & 1306.0 & 70.8 & 101.5 \\
\hline DD-82 & 77 & 63196 & 1.4 & $\begin{array}{r}11.742 \\
4\end{array}$ & 1.0 & 2.6982 & 2.1 & 0.2298 & 1.9 & 0.89 & 1333.4 & 22.9 & 1328.0 & 15.9 & 1319.2 & 19.1 & 1319.2 & 19.1 & 101.1 \\
\hline DD-54 & 193 & $\begin{array}{r}18109 \\
2\end{array}$ & 0.8 & $\begin{array}{r}11.149 \\
3\end{array}$ & 0.5 & 3.1056 & 1.6 & 0.2511 & 1.5 & 0.94 & 1444.3 & 18.9 & 1434.1 & 12.0 & 1419.0 & 10.2 & 1419.0 & 10.2 & 101.8 \\
\hline DD-24 & 91 & $\begin{array}{r}16872 \\
3\end{array}$ & 1.3 & $\begin{array}{r}10.952 \\
4\end{array}$ & 1.1 & 3.1942 & 1.7 & 0.2537 & 1.3 & 0.75 & 1457.7 & 16.5 & 1455.8 & 13.2 & 1452.9 & 21.6 & 1452.9 & 21.6 & 100.3 \\
\hline DD-90 & 120 & $\begin{array}{r}13961 \\
7\end{array}$ & 0.6 & $\begin{array}{r}10.003 \\
6\end{array}$ & 0.4 & 3.9762 & 1.4 & 0.2885 & 1.4 & 0.97 & 1633.9 & 19.5 & 1629.3 & 11.3 & 1623.4 & 6.6 & 1623.4 & 6.6 & 100.7 \\
\hline DD-94 & 670 & $\begin{array}{r}68852 \\
9 \\
\end{array}$ & 52.4 & 7.9022 & 0.2 & 5.8370 & 1.5 & 0.3345 & 1.5 & 0.99 & 1860.3 & 23.4 & 1951.9 & 12.6 & 2050.5 & 2.8 & 2050.5 & 2.8 & 90.7 \\
\hline DD-61 & 152 & 41558 & 1.1 & 7.8128 & 0.4 & 5.7212 & 0.8 & 0.3242 & 0.7 & 0.89 & 1810.2 & 11.3 & 1934.6 & 6.9 & 2070.6 & 6.4 & 2070.6 & 6.4 & 87.4 \\
\hline DD-6 & 506 & $\begin{array}{r}80117 \\
6\end{array}$ & 10.5 & 7.7113 & 0.1 & 6.4277 & 1.1 & 0.3595 & 1.1 & 0.99 & 1979.7 & 18.4 & 2036.1 & 9.6 & 2093.6 & 2.2 & 2093.6 & 2.2 & 94.6 \\
\hline DD-32 & 79 & 94808 & 1.1 & 7.6867 & 0.5 & 7.0060 & 2.9 & 0.3906 & 2.8 & 0.98 & 2125.5 & 50.9 & 2112.2 & 25.4 & 2099.2 & 8.8 & 2099.2 & 8.8 & 101.3 \\
\hline DD-80 & 163 & $\begin{array}{r}20707 \\
2\end{array}$ & 0.5 & 7.6714 & 0.4 & 6.7214 & 0.9 & 0.3740 & 0.8 & 0.92 & 2048.0 & 14.8 & 2075.4 & 8.1 & 2102.7 & 6.5 & 2102.7 & 6.5 & 97.4 \\
\hline DD-12 & 228 & $\begin{array}{r}23021 \\
2 \\
\end{array}$ & 2.2 & 7.6480 & 0.6 & 6.5485 & 4.8 & 0.3632 & 4.8 & 0.99 & 1997.5 & 82.5 & 2052.4 & 42.7 & 2108.1 & 10.5 & 2108.1 & 10.5 & 94.8 \\
\hline DD-63 & 379 & $\begin{array}{r}40335 \\
5\end{array}$ & 1.4 & 7.5855 & 0.1 & 6.8853 & 1.8 & 0.3788 & 1.8 & 1.00 & 2070.7 & 32.0 & 2096.8 & 16.0 & 2122.5 & 2.4 & 2122.5 & 2.4 & 97.6 \\
\hline DD-77 & 88 & $\begin{array}{r}23972 \\
0\end{array}$ & 2.2 & 7.5258 & 0.4 & 7.4213 & 1.4 & 0.4051 & 1.3 & 0.95 & 2192.3 & 23.9 & 2163.5 & 12.1 & 2136.3 & 7.3 & 2136.3 & 7.3 & 102.6 \\
\hline DD-53 & 190 & $\begin{array}{r}23821 \\
2\end{array}$ & 2.8 & 7.4582 & 0.4 & 6.7809 & 1.2 & 0.3668 & 1.2 & 0.95 & 2014.3 & 20.0 & 2083.2 & 10.8 & 2152.1 & 6.7 & 2152.1 & 6.7 & 93.6 \\
\hline
\end{tabular}




\begin{tabular}{|c|c|c|c|c|c|c|c|c|c|c|c|c|c|c|c|c|c|c|c|}
\hline Analysis & U & $206 \mathrm{~Pb}$ & $\begin{array}{c}\mathrm{U} / \mathrm{T} \\
\mathrm{h}\end{array}$ & $206 \mathrm{~Pb}^{*}$ & \pm & $207 \mathrm{~Pb}^{*}$ & \pm & $\underset{*}{206 \mathrm{~Pb}}$ & \pm & $\begin{array}{c}\text { erro } \\
\mathrm{r}\end{array}$ & $\underset{*}{206 \mathrm{~Pb}}$ & \pm & $\underset{*}{207 \mathrm{~Pb}}$ & \pm & $\underset{*}{206 \mathrm{~Pb}}$ & \pm & $\begin{array}{l}\text { Best } \\
\text { age }\end{array}$ & \pm & Conc \\
\hline & $\begin{array}{c}\text { (ppm } \\
\text { ) }\end{array}$ & $204 \mathrm{~Pb}$ & & $207 \mathrm{~Pb}^{*}$ & $(\%)$ & $235 \mathrm{U}^{*}$ & $(\%)$ & $238 \mathrm{U}$ & (\%) & corr. & $238 \mathrm{U}^{*}$ & (Ma) & $235 \mathrm{U}$ & (Ma) & $\underset{*}{207 \mathrm{~Pb}}$ & (Ma) & (Ma) & (Ma) & (\%) \\
\hline DD-68 & 46 & $\begin{array}{r}15638 \\
0\end{array}$ & 1.1 & 7.2768 & 1.9 & 6.9429 & 5.5 & 0.3664 & 5.2 & 0.94 & 2012.5 & 89.4 & 2104.2 & 48.9 & 2195.0 & 32.8 & 2195.0 & 32.8 & 91.7 \\
\hline DD-16 & 110 & 83122 & 2.3 & 7.2672 & 0.4 & 7.5221 & 1.6 & 0.3965 & 1.6 & 0.97 & 2152.7 & 28.7 & 2175.6 & 14.5 & 2197.3 & 7.3 & 2197.3 & 7.3 & 98.0 \\
\hline DD-41 & 121 & 93308 & 8.0 & 6.2948 & 0.1 & 9.7730 & 1.3 & 0.4462 & 1.3 & 0.99 & 2378.3 & 26.3 & 2413.6 & 12.3 & 2443.6 & 2.4 & 2443.6 & 2.4 & 97.3 \\
\hline DD-92 & 368 & $\begin{array}{r}38819 \\
9 \\
\end{array}$ & 1.2 & 5.5942 & 0.1 & $\begin{array}{r}11.898 \\
8 \\
\end{array}$ & 1.7 & 0.4828 & 1.7 & 1.00 & 2539.3 & 36.1 & 2596.5 & 16.1 & 2641.3 & 1.6 & 2641.3 & 1.6 & 96.1 \\
\hline DD-13 & 32 & 63846 & 0.6 & 5.3856 & 0.6 & $\begin{array}{r}13.198 \\
1\end{array}$ & 1.4 & 0.5155 & 1.3 & 0.90 & 2680.1 & 28.6 & 2693.9 & 13.7 & 2704.3 & 10.4 & 2704.3 & 10.4 & 99.1 \\
\hline DD-35 & 795 & $\begin{array}{r}82365 \\
6\end{array}$ & 1.1 & 4.2373 & 1.0 & $\begin{array}{r}16.421 \\
0\end{array}$ & 2.5 & 0.5046 & 2.2 & 0.91 & 2633.7 & 48.1 & 2901.6 & 23.5 & 3093.2 & 16.6 & 3093.2 & 16.6 & 85.1 \\
\hline
\end{tabular}

\begin{tabular}{|c|c|c|c|c|c|c|c|c|c|c|c|c|c|c|c|c|c|c|c|}
\hline Analysis & U & $206 \mathrm{~Pb}$ & $\begin{array}{c}\mathrm{U} / \mathrm{T} \\
\mathrm{h}\end{array}$ & $206 \mathrm{~Pb}^{*}$ & \pm & 207 $\mathrm{Pb}^{*}$ & \pm & $\underset{*}{206 \mathrm{~Pb}}$ & \pm & $\begin{array}{c}\text { erro } \\
\mathrm{r}\end{array}$ & $\underset{*}{206 \mathrm{~Pb}}$ & \pm & $\underset{*}{207 \mathrm{~Pb}}$ & \pm & $\underset{*}{206 \mathrm{~Pb}}$ & \pm & $\begin{array}{c}\text { Best } \\
\text { age }\end{array}$ & \pm & Conc \\
\hline & $\begin{array}{c}(\mathrm{ppm} \\
)\end{array}$ & $204 \mathrm{~Pb}$ & & $207 \mathrm{~Pb}^{*}$ & $(\%)$ & $235 \mathrm{U}^{*}$ & $(\%)$ & $238 \mathrm{U}$ & $(\%)$ & corr. & $238 \mathrm{U}^{*}$ & $(\mathrm{Ma})$ & $235 \mathrm{U}$ & (Ma) & $\underset{*}{207 \mathrm{~Pb}}$ & $(\mathrm{Ma})$ & (Ma) & $(\mathrm{Ma})$ & $(\%)$ \\
\hline STPB- 57 & 859 & $\begin{array}{r}18823 \\
3 \\
\end{array}$ & 3.2 & $\begin{array}{r}17.158 \\
1 \\
\end{array}$ & 0.6 & 0.6948 & 1.1 & 0.0865 & 1.0 & 0.87 & 534.6 & 5.0 & 535.7 & 4.7 & 540.4 & 12.3 & 534.6 & 5.0 & 98.9 \\
\hline STPB-11 & 29 & 6798 & 0.8 & $\begin{array}{r}16.829 \\
5 \\
\end{array}$ & $\begin{array}{r}15 . \\
4 \\
\end{array}$ & 0.7103 & $\begin{array}{r}17 . \\
1 \\
\end{array}$ & 0.0867 & 7.6 & 0.44 & 536.0 & 39.1 & 544.9 & 72.4 & 582.5 & 335.5 & 536.0 & 39.1 & 92.0 \\
\hline STPB-61 & 73 & 16375 & 0.9 & $\begin{array}{r}16.985 \\
3 \\
\end{array}$ & 5.8 & 0.7047 & 6.3 & 0.0868 & 2.3 & 0.37 & 536.6 & 12.0 & 541.6 & 26.4 & 562.4 & 127.1 & 536.6 & 12.0 & 95.4 \\
\hline STPB-69 & 239 & 71580 & 0.9 & $\begin{array}{r}16.910 \\
6 \\
\end{array}$ & 2.1 & 0.7080 & 3.0 & 0.0868 & 2.1 & 0.71 & 536.8 & 11.0 & 543.5 & 12.7 & 572.0 & 46.2 & 536.8 & 11.0 & 93.8 \\
\hline STPB-72 & 47 & 19400 & 0.8 & $\begin{array}{r}18.286 \\
2\end{array}$ & $\begin{array}{r}10 . \\
1\end{array}$ & 0.6571 & $\begin{array}{r}10 . \\
2\end{array}$ & 0.0871 & 1.7 & 0.17 & 538.6 & 9.0 & 512.8 & 41.1 & 399.4 & 226.1 & 538.6 & 9.0 & 134.9 \\
\hline STPB-83 & 76 & 38499 & 0.7 & $\begin{array}{r}17.255 \\
8 \\
\end{array}$ & 7.4 & 0.6985 & 7.6 & 0.0874 & 1.8 & 0.23 & 540.3 & 9.2 & 537.9 & 31.7 & 528.0 & 162.2 & 540.3 & 9.2 & 102.3 \\
\hline STPB-49 & 205 & 33362 & 1.2 & $\begin{array}{r}16.540 \\
3 \\
\end{array}$ & 6.5 & 0.7349 & 6.6 & 0.0882 & 1.0 & 0.16 & 544.6 & 5.4 & 559.4 & 28.3 & 620.0 & 140.1 & 544.6 & 5.4 & 87.8 \\
\hline STPB-2 & 16 & 5063 & 0.6 & $\begin{array}{r}17.623 \\
9 \\
\end{array}$ & $\begin{array}{r}19 . \\
2 \\
\end{array}$ & 0.6912 & $\begin{array}{r}20 . \\
0 \\
\end{array}$ & 0.0884 & 5.6 & 0.28 & 545.8 & 29.3 & 533.5 & 83.2 & 481.5 & 428.0 & 545.8 & 29.3 & 113.4 \\
\hline STPB- 5 & 303 & 48215 & 0.9 & $\begin{array}{r}17.018 \\
3 \\
\end{array}$ & 1.1 & 0.7169 & 1.8 & 0.0885 & 1.4 & 0.78 & 546.6 & 7.4 & 548.8 & 7.7 & 558.2 & 24.6 & 546.6 & 7.4 & 97.9 \\
\hline STPB-44 & 267 & 57936 & 1.3 & $\begin{array}{r}17.349 \\
5 \\
\end{array}$ & 1.8 & 0.7040 & 2.1 & 0.0886 & 1.2 & 0.54 & 547.1 & 6.1 & 541.2 & 9.0 & 516.0 & 39.4 & 547.1 & 6.1 & 106.0 \\
\hline STPB-39 & 120 & 37656 & 0.7 & $\begin{array}{r}16.972 \\
0 \\
\end{array}$ & 5.6 & 0.7230 & 5.8 & 0.0890 & 1.8 & 0.31 & 549.6 & 9.5 & 552.4 & 24.9 & 564.1 & 121.1 & 549.6 & 9.5 & 97.4 \\
\hline STPB- 80 & 90 & 19603 & 2.8 & $\begin{array}{r}17.572 \\
3 \\
\end{array}$ & 4.9 & 0.6994 & 5.0 & 0.0891 & 1.3 & 0.26 & 550.5 & 7.0 & 538.5 & 21.1 & 487.9 & 107.4 & 550.5 & 7.0 & 112.8 \\
\hline STPB-67 & 129 & 23076 & 0.6 & $\begin{array}{r}16.332 \\
4 \\
\end{array}$ & $\begin{array}{r}10 . \\
9 \\
\end{array}$ & 0.7552 & $\begin{array}{r}11 . \\
8 \\
\end{array}$ & 0.0895 & 4.6 & 0.39 & 552.3 & 24.2 & 571.2 & 51.6 & 647.3 & 234.3 & 552.3 & 24.2 & 85.3 \\
\hline STPB-79 & 30 & 8049 & 2.0 & $\begin{array}{r}16.855 \\
1 \\
\end{array}$ & $\begin{array}{r}16 . \\
3 \\
\end{array}$ & 0.7333 & $\begin{array}{r}16 . \\
4 \\
\end{array}$ & 0.0896 & 1.9 & 0.11 & 553.4 & 9.8 & 558.5 & 70.6 & 579.2 & 356.2 & 553.4 & 9.8 & 95.5 \\
\hline STPB-74 & 252 & 23809 & 1.1 & $\begin{array}{r}16.346 \\
6 \\
\end{array}$ & 4.3 & 0.7568 & 4.6 & 0.0897 & 1.6 & 0.35 & 553.9 & 8.6 & 572.2 & 20.3 & 645.4 & 93.2 & 553.9 & 8.6 & 85.8 \\
\hline STPB-65 & 167 & 77434 & 1.1 & $\begin{array}{r}17.422 \\
7 \\
\end{array}$ & 2.3 & 0.7108 & 2.4 & 0.0898 & 0.6 & 0.24 & 554.5 & 3.0 & 545.2 & 10.0 & 506.8 & 50.3 & 554.5 & 3.0 & 109.4 \\
\hline STPB-34 & 99 & 71106 & 5.6 & $\begin{array}{r}17.279 \\
1 \\
\end{array}$ & 5.4 & 0.7176 & 5.6 & 0.0899 & 1.5 & 0.27 & 555.2 & 8.0 & 549.3 & 23.6 & 525.0 & 117.7 & 555.2 & 8.0 & 105.8 \\
\hline STPB-35 & 120 & 49539 & 5.6 & $\begin{array}{r}17.100 \\
7 \\
\end{array}$ & 4.0 & 0.7274 & 4.1 & 0.0902 & 0.9 & 0.22 & 556.8 & 4.8 & 555.0 & 17.6 & 547.7 & 87.8 & 556.8 & 4.8 & 101.7 \\
\hline STPB-1 & 132 & 24426 & 1.8 & $\begin{array}{r}17.030 \\
5 \\
\end{array}$ & 1.9 & 0.7309 & 2.5 & 0.0903 & 1.6 & 0.63 & 557.2 & 8.3 & 557.1 & 10.6 & 556.6 & 41.8 & 557.2 & 8.3 & 100.1 \\
\hline STPB-91 & 40 & 8883 & 0.8 & $\begin{array}{r}16.783 \\
7\end{array}$ & 8.3 & 0.7417 & 8.7 & 0.0903 & 2.6 & 0.30 & 557.2 & 13.9 & 563.4 & 37.7 & 588.4 & 180.6 & 557.2 & 13.9 & 94.7 \\
\hline STPB-55 & 87 & 24889 & 1.5 & $\begin{array}{r}17.284 \\
9 \\
\end{array}$ & 2.9 & 0.7203 & 3.2 & 0.0903 & 1.3 & 0.41 & 557.3 & 7.0 & 550.9 & 13.5 & 524.2 & 63.6 & 557.3 & 7.0 & 106.3 \\
\hline STPB-89 & 43 & 8828 & 1.2 & $\begin{array}{r}17.197 \\
0 \\
\end{array}$ & $\begin{array}{r}10 . \\
8 \\
\end{array}$ & 0.7242 & $\begin{array}{r}10 . \\
9 \\
\end{array}$ & 0.0903 & 1.3 & 0.12 & 557.4 & 6.8 & 553.1 & 46.4 & 535.4 & 236.7 & 557.4 & 6.8 & 104.1 \\
\hline STPB-62 & 147 & $\begin{array}{r}12147 \\
4 \\
\end{array}$ & 0.7 & $\begin{array}{r}16.944 \\
7 \\
\end{array}$ & 3.1 & 0.7352 & 3.2 & 0.0904 & 0.6 & 0.18 & 557.6 & 3.1 & 559.6 & 13.7 & 567.7 & 68.2 & 557.6 & 3.1 & 98.2 \\
\hline STPB-86 & 218 & $\begin{array}{r}10577 \\
5 \\
\end{array}$ & 0.8 & $\begin{array}{r}17.310 \\
9 \\
\end{array}$ & 1.6 & 0.7213 & 2.7 & 0.0906 & 2.1 & 0.80 & 558.8 & 11.4 & 551.4 & 11.3 & 520.9 & 35.0 & 558.8 & 11.4 & 107.3 \\
\hline STPB-47 & 45 & 9519 & 1.3 & $\begin{array}{r}17.473 \\
6 \\
\end{array}$ & 5.9 & 0.7149 & 7.0 & 0.0906 & 3.7 & 0.53 & 559.1 & 19.8 & 547.6 & 29.5 & 500.4 & 130.3 & 559.1 & 19.8 & 111.7 \\
\hline STPB-78 & 133 & 39681 & 1.4 & $\begin{array}{r}16.797 \\
3 \\
\end{array}$ & 2.1 & 0.7453 & 2.6 & 0.0908 & 1.5 & 0.58 & 560.2 & 8.3 & 565.5 & 11.4 & 586.7 & 46.4 & 560.2 & 8.3 & 95.5 \\
\hline STPB-10 & 162 & 44647 & 0.9 & $\begin{array}{r}16.813 \\
9 \\
\end{array}$ & 2.4 & 0.7461 & 3.1 & 0.0910 & 2.0 & 0.65 & 561.3 & 10.9 & 566.0 & 13.5 & 584.5 & 51.2 & 561.3 & 10.9 & 96.0 \\
\hline STPB-85 & 112 & 33585 & 6.3 & $\begin{array}{r}17.149 \\
4\end{array}$ & 4.3 & 0.7320 & 4.6 & 0.0910 & 1.6 & 0.34 & 561.7 & 8.5 & 557.7 & 19.8 & 541.5 & 94.9 & 561.7 & 8.5 & 103.7 \\
\hline STPB-27 & 145 & 31154 & 1.0 & $\begin{array}{r}17.539 \\
6\end{array}$ & 2.8 & 0.7158 & 3.0 & 0.0911 & 1.1 & 0.35 & 561.8 & 5.8 & 548.2 & 12.9 & 492.1 & 62.7 & 561.8 & 5.8 & 114.2 \\
\hline STPB-52 & 127 & 33111 & 1.5 & $\begin{array}{r}17.483 \\
1 \\
\end{array}$ & 4.2 & 0.7189 & 4.4 & 0.0912 & 1.3 & 0.30 & 562.4 & 7.1 & 550.0 & 18.7 & 499.2 & 92.7 & 562.4 & 7.1 & 112.7 \\
\hline
\end{tabular}




\begin{tabular}{|c|c|c|c|c|c|c|c|c|c|c|c|c|c|c|c|c|c|c|c|}
\hline Analysis & $u$ & $206 \mathrm{~Pb}$ & $\begin{array}{c}\mathrm{U} / \mathrm{T} \\
\mathrm{h}\end{array}$ & $206 \mathrm{~Pb}^{*}$ & \pm & $207 \mathrm{~Pb}^{*}$ & \pm & $\underset{*}{206 \mathrm{~Pb}}$ & \pm & $\begin{array}{c}\text { erro } \\
\mathrm{r}\end{array}$ & $\underset{*}{206 \mathrm{~Pb}}$ & \pm & $\underset{*}{207 \mathrm{~Pb}}$ & \pm & $\underset{*}{206 \mathrm{~Pb}}$ & \pm & $\begin{array}{l}\text { Best } \\
\text { age }\end{array}$ & \pm & Conc \\
\hline & $\begin{array}{c}\text { (ppm } \\
\end{array}$ & $204 \mathrm{~Pb}$ & & $207 \mathrm{~Pb}^{*}$ & $(\%)$ & $235 \mathrm{U}^{*}$ & (\%) & $238 \mathrm{U}$ & $(\%)$ & corr. & $238 \mathrm{U}^{*}$ & (Ma) & $235 \mathrm{U}$ & (Ma) & $\underset{*}{207 \mathrm{~Pb}}$ & (Ma) & (Ma) & (Ma) & $(\%)$ \\
\hline STPB-62 & 140 & 32753 & 1.2 & $\begin{array}{r}17.231 \\
5 \\
\end{array}$ & 2.1 & 0.7303 & 2.2 & 0.0913 & 0.8 & 0.34 & 563.1 & 4.1 & 556.8 & 9.6 & 531.0 & 46.1 & 563.1 & 4.1 & 106.0 \\
\hline STPB-76 & 22 & 6183 & 0.6 & $\begin{array}{r}19.971 \\
2 \\
\end{array}$ & $\begin{array}{r}17 . \\
4 \\
\end{array}$ & 0.6310 & $\begin{array}{r}17 . \\
9\end{array}$ & 0.0914 & 3.9 & 0.22 & 563.8 & 20.8 & 496.7 & 70.3 & 198.3 & 407.7 & 563.8 & 20.8 & 284.3 \\
\hline STPB-21 & 574 & 18591 & 2.5 & $\begin{array}{r}16.014 \\
3 \\
\end{array}$ & 0.6 & 0.7873 & 1.9 & 0.0914 & 1.8 & 0.95 & 564.1 & 9.8 & 589.7 & 8.6 & 689.3 & 13.0 & 564.1 & 9.8 & 81.8 \\
\hline STPB-45 & 147 & 29967 & 0.7 & $\begin{array}{r}17.132 \\
2 \\
\end{array}$ & 2.5 & 0.7370 & 2.7 & 0.0916 & 1.0 & 0.38 & 564.8 & 5.5 & 560.6 & 11.5 & 543.7 & 53.9 & 564.8 & 5.5 & 103.9 \\
\hline STPB-68 & 47 & 11136 & 1.4 & $\begin{array}{r}17.985 \\
6 \\
\end{array}$ & 9.9 & 0.7046 & $\begin{array}{r}10 . \\
1 \\
\end{array}$ & 0.0919 & 2.3 & 0.22 & 566.8 & 12.2 & 541.5 & 42.5 & 436.4 & 220.0 & 566.8 & 12.2 & 129.9 \\
\hline STPB-38 & 94 & 32698 & 0.9 & $\begin{array}{r}16.566 \\
1 \\
\end{array}$ & 2.3 & 0.7664 & 2.9 & 0.0921 & 1.8 & 0.61 & 567.9 & 9.7 & 577.7 & 12.8 & 616.6 & 49.6 & 567.9 & 9.7 & 92.1 \\
\hline STPB-100 & 25 & 5478 & 1.2 & $\begin{array}{r}15.841 \\
7 \\
\end{array}$ & $\begin{array}{r}10 . \\
7 \\
\end{array}$ & 0.8037 & $\begin{array}{r}11 . \\
4 \\
\end{array}$ & 0.0923 & 4.0 & 0.35 & 569.4 & 21.6 & 598.9 & 51.7 & 712.4 & 228.0 & 569.4 & 21.6 & 79.9 \\
\hline STPB-99 & 192 & $\begin{array}{r}10852 \\
7 \\
\end{array}$ & 0.9 & $\begin{array}{r}16.727 \\
2 \\
\end{array}$ & 1.3 & 0.7656 & 1.8 & 0.0929 & 1.3 & 0.71 & 572.6 & 7.1 & 577.3 & 8.1 & 595.7 & 28.2 & 572.6 & 7.1 & 96.1 \\
\hline STPB-22 & 35 & 9359 & 1.2 & $\begin{array}{r}16.735 \\
6 \\
\end{array}$ & 7.8 & 0.7686 & 8.5 & 0.0933 & 3.4 & 0.40 & 575.0 & 18.6 & 579.0 & 37.4 & 594.6 & 168.6 & 575.0 & 18.6 & 96.7 \\
\hline STPB-64 & 137 & 23444 & 1.5 & $\begin{array}{r}16.865 \\
4 \\
\end{array}$ & 2.5 & 0.7631 & 4.1 & 0.0933 & 3.3 & 0.79 & 575.2 & 18.0 & 575.8 & 18.1 & 577.9 & 54.3 & 575.2 & 18.0 & 99.5 \\
\hline STPB- 51 & 164 & 42004 & 0.8 & $\begin{array}{r}17.168 \\
1 \\
\end{array}$ & 2.4 & 0.7529 & 2.6 & 0.0937 & 1.2 & 0.45 & 577.6 & 6.6 & 569.9 & 11.5 & 539.1 & 51.6 & 577.6 & 6.6 & 107.2 \\
\hline STPB-7 & 78 & 42709 & 0.7 & $\begin{array}{r}16.603 \\
5 \\
\end{array}$ & 3.8 & 0.7800 & 4.8 & 0.0939 & 3.0 & 0.62 & 578.7 & 16.7 & 585.5 & 21.6 & 611.8 & 82.1 & 578.7 & 16.7 & 94.6 \\
\hline STPB-31 & 84 & 27001 & 1.2 & $\begin{array}{r}17.494 \\
0 \\
\end{array}$ & 2.4 & 0.7449 & 2.7 & 0.0945 & 1.3 & 0.47 & 582.1 & 7.0 & 565.2 & 11.6 & 497.8 & 52.2 & 582.1 & 7.0 & 116.9 \\
\hline STPB-29 & 93 & 17670 & 1.5 & $\begin{array}{r}17.373 \\
5 \\
\end{array}$ & 4.6 & 0.7500 & 4.8 & 0.0945 & 1.3 & 0.28 & 582.1 & 7.4 & 568.2 & 20.9 & 513.0 & 101.3 & 582.1 & 7.4 & 113.5 \\
\hline STPB-90 & 89 & 29610 & 1.5 & $\begin{array}{r}16.610 \\
0 \\
\end{array}$ & 2.9 & 0.7863 & 3.3 & 0.0947 & 1.6 & 0.49 & 583.4 & 9.2 & 589.1 & 15.0 & 610.9 & 62.9 & 583.4 & 9.2 & 95.5 \\
\hline STPB-23 & 103 & 33778 & 2.3 & $\begin{array}{r}16.594 \\
9 \\
\end{array}$ & 3.0 & 0.8075 & 8.3 & 0.0972 & 7.7 & 0.93 & 597.9 & 44.2 & 601.1 & 37.6 & 612.9 & 63.9 & 597.9 & 44.2 & 97.6 \\
\hline STPB-71 & 172 & 24830 & 1.5 & $\begin{array}{r}16.715 \\
3 \\
\end{array}$ & 1.4 & 0.8043 & 2.2 & 0.0975 & 1.7 & 0.77 & 599.7 & 9.7 & 599.2 & 9.9 & 597.3 & 30.4 & 599.7 & 9.7 & 100.4 \\
\hline STPB-43 & 82 & 52577 & 0.9 & $\begin{array}{r}16.655 \\
4 \\
\end{array}$ & 4.9 & 0.8117 & 5.1 & 0.0981 & 1.4 & 0.28 & 603.0 & 8.1 & 603.4 & 23.0 & 605.0 & 105.1 & 603.0 & 8.1 & 99.7 \\
\hline STPB-12 & 381 & $\begin{array}{r}13266 \\
0 \\
\end{array}$ & 5.1 & $\begin{array}{r}16.590 \\
1 \\
\end{array}$ & 0.9 & 0.8323 & 1.2 & 0.1001 & 0.7 & 0.61 & 615.3 & 4.1 & 614.9 & 5.3 & 613.5 & 19.9 & 615.3 & 4.1 & 100.3 \\
\hline STPB-59 & 168 & 62328 & 0.9 & $\begin{array}{r}16.748 \\
9 \\
\end{array}$ & 1.5 & 0.8264 & 2.2 & 0.1004 & 1.6 & 0.73 & 616.7 & 9.4 & 611.6 & 10.0 & 592.9 & 32.3 & 616.7 & 9.4 & 104.0 \\
\hline STPB- 50 & 50 & 12566 & 1.0 & $\begin{array}{r}16.484 \\
5 \\
\end{array}$ & 5.6 & 0.8440 & 6.1 & 0.1009 & 2.3 & 0.38 & 619.7 & 13.7 & 621.4 & 28.2 & 627.3 & 120.6 & 619.7 & 13.7 & 98.8 \\
\hline STPB-93 & 188 & 27590 & 0.8 & $\begin{array}{r}15.581 \\
8 \\
\end{array}$ & 8.1 & 0.9004 & 8.3 & 0.1018 & 2.0 & 0.24 & 624.7 & 11.8 & 651.9 & 40.1 & 747.5 & 171.2 & 624.7 & 11.8 & 83.6 \\
\hline STPB-75 & 65 & 32507 & 1.4 & $\begin{array}{r}16.671 \\
0 \\
\end{array}$ & 4.6 & 0.8452 & 5.0 & 0.1022 & 1.9 & 0.39 & 627.2 & 11.6 & 622.0 & 23.0 & 603.0 & 98.6 & 627.2 & 11.6 & 104.0 \\
\hline STPB-42 & 61 & 19309 & 1.1 & $\begin{array}{r}16.496 \\
6 \\
\end{array}$ & 4.3 & 0.8591 & 4.5 & 0.1028 & 1.3 & 0.29 & 630.8 & 8.0 & 629.7 & 21.3 & 625.7 & 93.6 & 630.8 & 8.0 & 100.8 \\
\hline STPB-14 & 209 & 81187 & 1.3 & $\begin{array}{r}16.231 \\
2 \\
\end{array}$ & 1.4 & 0.8838 & 1.6 & 0.1040 & 0.8 & 0.47 & 638.0 & 4.6 & 643.0 & 7.7 & 660.6 & 30.7 & 638.0 & 4.6 & 96.6 \\
\hline STPB-41 & 236 & 55651 & 1.3 & $\begin{array}{r}16.446 \\
6 \\
\end{array}$ & 1.6 & 0.8755 & 2.1 & 0.1044 & 1.4 & 0.65 & 640.3 & 8.4 & 638.5 & 10.0 & 632.3 & 34.3 & 640.3 & 8.4 & 101.3 \\
\hline STPB-9 & 148 & 62693 & 1.5 & $\begin{array}{r}16.325 \\
7 \\
\end{array}$ & 2.0 & 0.8860 & 2.3 & 0.1049 & 1.1 & 0.47 & 643.1 & 6.5 & 644.2 & 10.8 & 648.2 & 43.0 & 643.1 & 6.5 & 99.2 \\
\hline STPB-82 & 393 & $\begin{array}{r}10090 \\
6 \\
\end{array}$ & 4.8 & $\begin{array}{r}16.520 \\
0 \\
\end{array}$ & 0.9 & 0.8791 & 1.8 & 0.1053 & 1.6 & 0.88 & 645.6 & 9.9 & 640.5 & 8.6 & 622.6 & 18.4 & 645.6 & 9.9 & 103.7 \\
\hline STPB-37 & 101 & 29970 & 1.9 & $\begin{array}{r}16.478 \\
4 \\
\end{array}$ & 3.4 & 0.8813 & 3.7 & 0.1053 & 1.4 & 0.38 & 645.6 & 8.6 & 641.7 & 17.4 & 628.1 & 72.9 & 645.6 & 8.6 & 102.8 \\
\hline STPB-94 & 368 & 83233 & 1.8 & $\begin{array}{r}16.358 \\
5 \\
\end{array}$ & 1.4 & 0.8929 & 1.7 & 0.1059 & 1.1 & 0.60 & 649.1 & 6.5 & 647.9 & 8.4 & 643.8 & 30.0 & 649.1 & 6.5 & 100.8 \\
\hline STPB-87 & 135 & 42631 & 0.8 & $\begin{array}{r}16.163 \\
0 \\
\end{array}$ & 3.3 & 0.9061 & 3.8 & 0.1062 & 1.9 & 0.50 & 650.8 & 12.0 & 655.0 & 18.5 & 669.6 & 71.0 & 650.8 & 12.0 & 97.2 \\
\hline STPB-6 & 169 & 23443 & 1.5 & $\begin{array}{r}15.074 \\
5 \\
\end{array}$ & 2.1 & 1.2284 & 4.8 & 0.1343 & 4.4 & 0.90 & 812.3 & 33.4 & 813.6 & 27.1 & 817.1 & 43.0 & 812.3 & 33.4 & 99.4 \\
\hline STPB-17 & 154 & $\begin{array}{r}10346 \\
9 \\
\end{array}$ & 1.2 & $\begin{array}{r}14.205 \\
1 \\
\end{array}$ & 0.8 & 1.5351 & 1.1 & 0.1582 & 0.7 & 0.66 & 946.5 & 6.2 & 944.6 & 6.6 & 939.9 & 16.5 & 939.9 & 16.5 & 100.7 \\
\hline STPB-46 & 138 & $\begin{array}{r}13603 \\
5 \\
\end{array}$ & 1.1 & $\begin{array}{r}13.893 \\
2 \\
\end{array}$ & 1.3 & 1.5668 & 1.6 & 0.1579 & 0.9 & 0.56 & 945.0 & 7.8 & 957.2 & 9.9 & 985.3 & 26.9 & 985.3 & 26.9 & 95.9 \\
\hline STPB-36 & 53 & 47293 & 2.3 & $\begin{array}{r}12.935 \\
2 \\
\end{array}$ & 3.7 & 1.9988 & 7.8 & 0.1875 & 6.9 & 0.88 & 1107.9 & 70.2 & 1115.1 & 53.0 & 1129.1 & 73.3 & 1129.1 & 73.3 & 98.1 \\
\hline STPB-56 & 124 & 79273 & 3.1 & $\begin{array}{r}12.809 \\
2 \\
\end{array}$ & 1.2 & 2.0141 & 2.2 & 0.1871 & 1.8 & 0.83 & 1105.7 & 18.3 & 1120.3 & 14.7 & 1148.6 & 23.9 & 1148.6 & 23.9 & 96.3 \\
\hline STPB-28 & 122 & 93506 & 1.5 & $\begin{array}{r}12.322 \\
0 \\
\end{array}$ & 0.8 & 2.4223 & 1.9 & 0.2165 & 1.7 & 0.90 & 1263.2 & 19.5 & 1249.2 & 13.5 & 1225.2 & 15.7 & 1225.2 & 15.7 & 103.1 \\
\hline STPB-95 & 164 & 96791 & 2.1 & $\begin{array}{r}12.232 \\
3 \\
\end{array}$ & 1.0 & 2.3937 & 1.3 & 0.2124 & 0.8 & 0.60 & 1241.4 & 8.6 & 1240.7 & 9.1 & 1239.5 & 19.9 & 1239.5 & 19.9 & 100.1 \\
\hline STPB- 40 & 88 & 70169 & 2.4 & $\begin{array}{r}12.209 \\
8 \\
\end{array}$ & 1.0 & 2.4476 & 2.1 & 0.2167 & 1.9 & 0.89 & 1264.6 & 21.9 & 1256.7 & 15.4 & 1243.2 & 18.7 & 1243.2 & 18.7 & 101.7 \\
\hline
\end{tabular}




\begin{tabular}{|c|c|c|c|c|c|c|c|c|c|c|c|c|c|c|c|c|c|c|c|}
\hline Analysis & U & $206 \mathrm{~Pb}$ & $\begin{array}{c}\mathrm{U} / \mathrm{T} \\
\mathrm{h}\end{array}$ & $206 \mathrm{~Pb}^{*}$ & \pm & $207 \mathrm{~Pb}^{*}$ & \pm & $\underset{*}{206 \mathrm{~Pb}}$ & \pm & $\begin{array}{c}\text { erro } \\
\mathrm{r}\end{array}$ & $\underset{*}{206 \mathrm{~Pb}}$ & \pm & $\underset{*}{207 \mathrm{~Pb}}$ & \pm & $\underset{*}{206 \mathrm{~Pb}}$ & \pm & $\begin{array}{c}\text { Best } \\
\text { age }\end{array}$ & \pm & Conc \\
\hline & $\begin{array}{c}\text { (ppm } \\
\text { ) }\end{array}$ & $204 \mathrm{~Pb}$ & & $207 \mathrm{~Pb}^{*}$ & (\%) & $235 \mathrm{U}^{*}$ & (\%) & $238 \mathrm{U}$ & (\%) & corr. & $238 \mathrm{U}^{*}$ & (Ma) & $235 \mathrm{U}$ & (Ma) & $207 \mathrm{~Pb}$ & (Ma) & (Ma) & (Ma) & (\%) \\
\hline STPB-66 & 60 & 40051 & 2.6 & $\begin{array}{r}11.546 \\
5 \\
\end{array}$ & 1.6 & 2.7218 & 3.3 & 0.2279 & 2.9 & 0.87 & 1323.6 & 34.2 & 1334.4 & 24.4 & 1351.7 & 31.2 & 1351.7 & 31.2 & 97.9 \\
\hline STPB-97 & 254 & $\begin{array}{r}25205 \\
2 \\
\end{array}$ & 2.3 & $\begin{array}{r}11.506 \\
1 \\
\end{array}$ & 0.4 & 2.8467 & 0.9 & 0.2376 & 0.8 & 0.89 & 1374.0 & 9.6 & 1367.9 & 6.5 & 1358.5 & 7.6 & 1358.5 & 7.6 & 101.1 \\
\hline STPB-84 & 47 & 32945 & 1.2 & 9.1082 & 1.5 & 4.8731 & 1.7 & 0.3219 & 0.9 & 0.51 & 1799.1 & 13.6 & 1797.6 & 14.4 & 1795.9 & 26.8 & 1795.9 & 26.8 & 100.2 \\
\hline STPB-58 & 49 & 25171 & 0.6 & 8.3177 & 1.2 & 4.5911 & 2.5 & 0.2770 & 2.2 & 0.88 & 1576.1 & 31.2 & 1747.7 & 21.1 & 1959.6 & 21.1 & 1959.6 & 21.1 & 80.4 \\
\hline STPB-25 & 46 & 65375 & 1.8 & 8.2535 & 1.7 & 5.5930 & 3.4 & 0.3348 & 2.9 & 0.87 & 1861.6 & 47.6 & 1915.0 & 29.2 & 1973.4 & 29.8 & 1973.4 & 29.8 & 94.3 \\
\hline STPB-81 & 102 & $\begin{array}{r}14771 \\
5 \\
\end{array}$ & 1.6 & 8.1217 & 0.8 & 5.9412 & 1.4 & 0.3500 & 1.2 & 0.85 & 1934.4 & 20.5 & 1967.3 & 12.5 & 2002.0 & 13.5 & 2002.0 & 13.5 & 96.6 \\
\hline STPB-58 & 183 & $\begin{array}{r}12563 \\
1 \\
\end{array}$ & 2.1 & 7.9903 & 1.3 & 5.9625 & 3.9 & 0.3455 & 3.6 & 0.94 & 1913.2 & 59.9 & 1970.4 & 33.5 & 2030.9 & 23.3 & 2030.9 & 23.3 & 94.2 \\
\hline STPB-3 & 108 & 70956 & 1.7 & 7.8960 & 0.9 & 5.5940 & 2.5 & 0.3204 & 2.3 & 0.93 & 1791.5 & 36.0 & 1915.2 & 21.3 & 2051.9 & 16.0 & 2051.9 & 16.0 & 87.3 \\
\hline STPB-70 & 249 & $\begin{array}{r}21341 \\
3 \\
\end{array}$ & 12.5 & 7.8446 & 0.4 & 6.3598 & 2.9 & 0.3618 & 2.9 & 0.99 & 1990.9 & 49.9 & 2026.7 & 25.8 & 2063.4 & 6.6 & 2063.4 & 6.6 & 96.5 \\
\hline STPB-32 & 201 & $\begin{array}{r}10167 \\
8 \\
\end{array}$ & 0.9 & 7.6703 & 0.3 & 6.9457 & 1.0 & 0.3864 & 0.9 & 0.94 & 2106.1 & 16.0 & 2104.5 & 8.5 & 2103.0 & 5.9 & 2103.0 & 5.9 & 100.1 \\
\hline STPB-96 & 187 & $\begin{array}{r}30361 \\
9 \\
\end{array}$ & 1.0 & 7.6536 & 0.3 & 6.7918 & 2.0 & 0.3770 & 1.9 & 0.99 & 2062.3 & 34.4 & 2084.7 & 17.4 & 2106.8 & 4.6 & 2106.8 & 4.6 & 97.9 \\
\hline STPB-63 & 117 & $\begin{array}{r}11548 \\
2 \\
\end{array}$ & 0.5 & 7.5947 & 0.3 & 7.0083 & 1.0 & 0.3860 & 0.9 & 0.96 & 2104.4 & 16.8 & 2112.5 & 8.6 & 2120.3 & 4.6 & 2120.3 & 4.6 & 99.2 \\
\hline STPB-73 & 19 & 25149 & 2.8 & 7.2577 & 2.3 & 7.6876 & 2.5 & 0.4047 & 1.0 & 0.40 & 2190.5 & 18.2 & 2195.2 & 22.1 & 2199.5 & 39.1 & 2199.5 & 39.1 & 99.6 \\
\hline STPB- 53 & 129 & 67229 & 1.3 & 7.1739 & 0.4 & 7.3389 & 2.8 & 0.3818 & 2.7 & 0.99 & 2084.9 & 48.6 & 2153.6 & 24.6 & 2219.7 & 7.0 & 2219.7 & 7.0 & 93.9 \\
\hline STPB-74 & 58 & $\begin{array}{r}17499 \\
0 \\
\end{array}$ & 1.3 & 5.4962 & 0.8 & $\begin{array}{r}11.778 \\
9 \\
\end{array}$ & 2.5 & 0.4695 & 2.3 & 0.94 & 2481.5 & 48.0 & 2587.0 & 23.1 & 2670.7 & 13.6 & 2670.7 & 13.6 & 92.9 \\
\hline STPB-15 & 265 & $\begin{array}{r}42294 \\
4 \\
\end{array}$ & 1.3 & 5.1712 & 0.3 & $\begin{array}{r}14.336 \\
7 \\
\end{array}$ & 2.0 & 0.5377 & 1.9 & 0.99 & 2773.8 & 43.6 & 2772.2 & 18.6 & 2771.1 & 4.8 & 2771.1 & 4.8 & 100.1 \\
\hline
\end{tabular}


Appendix 2. Norphlet Formation Sandstone Composition

\begin{tabular}{|c|c|c|c|c|c|c|c|c|c|c|c|c|c|}
\hline & Qt & $\mathbf{F}$ & $\mathbf{L}$ & Qm & $\mathbf{F}$ & Lt & Qp & Fpt & Fpu & Fk & Ls & Lv & Lm \\
\hline \multicolumn{14}{|l|}{ P1004 } \\
\hline Total & 245 & 151 & 5 & 237 & 151 & 13 & 8 & 8 & 63 & 80 & 1 & 0 & 4 \\
\hline Total/401 & 0.611 & 0.377 & 0.012 & 0.591 & 0.377 & 0.032 & 0.020 & 0.020 & 0.157 & 0.200 & 0.002 & 0.000 & 0.010 \\
\hline relative $\%$ & 61.1 & 37.7 & 1.2 & 59.1 & 37.7 & 3.2 & 2.0 & 2.0 & 15.7 & 20.0 & 0.2 & 0.0 & 1.0 \\
\hline \multicolumn{14}{|l|}{ P1096 } \\
\hline Total & 253 & 141 & 6 & 243 & 141 & 16 & 10 & 5 & 57 & 79 & 0 & 0 & 6 \\
\hline Total/400 & 0.633 & 0.353 & 0.015 & 0.608 & 0.353 & 0.040 & 0.025 & 0.013 & 0.143 & 0.198 & 0.000 & 0.000 & 0.015 \\
\hline relative $\%$ & 63.3 & 35.3 & 1.5 & 60.8 & 35.3 & 4.0 & 2.5 & 1.3 & 14.3 & 19.8 & 0.0 & 0.0 & 1.5 \\
\hline \multicolumn{14}{|l|}{ P1080 } \\
\hline Total & 271 & 109 & 20 & 256 & 109 & 35 & 15 & 7 & 55 & 47 & 3 & 0 & 17 \\
\hline Total/400 & 0.678 & 0.273 & 0.050 & 0.640 & 0.273 & 0.088 & 0.038 & 0.018 & 0.138 & 0.118 & 0.008 & 0.000 & 0.043 \\
\hline relative $\%$ & 67.8 & 27.3 & 5.0 & 64.0 & 27.3 & 8.8 & 3.8 & 1.8 & 13.8 & 11.8 & 0.8 & 0.0 & 4.3 \\
\hline \multicolumn{14}{|c|}{$\begin{array}{c}\text { OCS-G-6396 } \\
17,503 \mathrm{ft} .\end{array}$} \\
\hline Total & 308 & 61 & 32 & 283 & 61 & 57 & 25 & 4 & 11 & 46 & 18 & 3 & 11 \\
\hline Total/401 & 0.768 & 0.152 & 0.080 & 0.706 & 0.152 & 0.142 & 0.062 & 0.010 & 0.027 & 0.115 & 0.045 & 0.007 & 0.027 \\
\hline relative $\%$ & 76.8 & 15.2 & 8.0 & 70.6 & 15.2 & 14.2 & 6.2 & 1.0 & 2.7 & 11.5 & 4.5 & 0.7 & 2.7 \\
\hline \multicolumn{14}{|c|}{$\begin{array}{c}\text { OCS-G-6396 } \\
17,586 \mathrm{ft} .\end{array}$} \\
\hline Total & 313 & 56 & 32 & 295 & 56 & 50 & 18 & 3 & 9 & 44 & 12 & 3 & 17 \\
\hline Total/401 & 0.781 & 0.140 & 0.080 & 0.736 & 0.140 & 0.125 & 0.045 & 0.007 & 0.022 & 0.110 & 0.030 & 0.007 & 0.042 \\
\hline relative $\%$ & 78.1 & 14.0 & 8.0 & 73.6 & 14.0 & 12.5 & 4.5 & 0.7 & 2.2 & 11.0 & 3.0 & 0.7 & 4.2 \\
\hline \multicolumn{14}{|c|}{$\begin{array}{c}\text { OCS-G-6396 } \\
17,559 \mathrm{ft} .\end{array}$} \\
\hline Total & 296 & 73 & 31 & 282 & 73 & 45 & 14 & 5 & 10 & 58 & 21 & 1 & 9 \\
\hline Total/400 & 0.740 & 0.183 & 0.078 & 0.705 & 0.183 & 0.113 & 0.035 & 0.013 & 0.025 & 0.145 & 0.053 & 0.003 & 0.023 \\
\hline relative $\%$ & 74.0 & 18.3 & 7.8 & 70.5 & 18.3 & 11.3 & 3.5 & 1.3 & 2.5 & 14.5 & 5.3 & 0.3 & 2.3 \\
\hline \multicolumn{14}{|c|}{$\begin{array}{c}\text { OCS-G-6396 } \\
17,562 \mathrm{ft} .\end{array}$} \\
\hline Total & 310 & 66 & 24 & 300 & 66 & 34 & 10 & 3 & 9 & 54 & 9 & 3 & 12 \\
\hline Total/400 & 0.775 & 0.165 & 0.060 & 0.750 & 0.165 & 0.085 & 0.025 & 0.008 & 0.023 & 0.135 & 0.023 & 0.008 & 0.030 \\
\hline relative $\%$ & 77.5 & 16.5 & 6.0 & 75.0 & 16.5 & 8.5 & 2.5 & 0.8 & 2.3 & 13.5 & 2.3 & 0.8 & 3.0 \\
\hline
\end{tabular}




\begin{tabular}{|c|c|c|c|c|c|c|c|c|c|c|c|c|c|}
\hline & Qt & $\mathbf{F}$ & $\mathbf{L}$ & Qm & $\mathbf{F}$ & Lt & Qp & Fpt & Fpu & Fk & Ls & Lv & Lm \\
\hline \multicolumn{14}{|c|}{$\begin{array}{c}\text { OCS-G-6406 } \\
22,566 \mathrm{ft} .\end{array}$} \\
\hline Total & 337 & 52 & 13 & 326 & 52 & 24 & 11 & 3 & 14 & 35 & 10 & 0 & 3 \\
\hline Total/402 & 0.838 & 0.129 & 0.032 & 0.811 & 0.129 & 0.060 & 0.027 & 0.007 & 0.035 & 0.087 & 0.025 & 0.000 & 0.007 \\
\hline relative $\%$ & 83.8 & 12.9 & 3.2 & 81.1 & 12.9 & 6.0 & 2.7 & 0.7 & 3.5 & 8.7 & 2.5 & 0.0 & 0.7 \\
\hline \multicolumn{14}{|c|}{$\begin{array}{c}\text { OCS-G-6406 } \\
22,633 \mathrm{ft} .\end{array}$} \\
\hline Total & 336 & 46 & 18 & 317 & 46 & 37 & 19 & 1 & 9 & 36 & 12 & 1 & 5 \\
\hline Total/400 & 0.840 & 0.115 & 0.045 & 0.793 & 0.115 & 0.093 & 0.048 & 0.003 & 0.023 & 0.090 & 0.030 & 0.003 & 0.013 \\
\hline relative \% & 84.0 & 11.5 & 4.5 & 79.3 & 11.5 & 9.3 & 4.8 & 0.3 & 2.3 & 9.0 & 3.0 & 0.3 & 1.3 \\
\hline \multicolumn{14}{|c|}{$\begin{array}{c}\text { OCS-G-6406 } \\
22,687 \mathrm{ft} .\end{array}$} \\
\hline Total & 334 & 57 & 19 & 320 & 57 & 33 & 14 & 1 & 15 & 41 & 14 & 0 & 5 \\
\hline Total/410 & 0.815 & 0.139 & 0.046 & 0.780 & 0.139 & 0.080 & 0.034 & 0.002 & 0.037 & 0.100 & 0.034 & 0.000 & 0.012 \\
\hline relative $\%$ & 81.5 & 13.9 & 4.6 & 78.0 & 13.9 & 8.0 & 3.4 & 0.2 & 3.7 & 10.0 & 3.4 & 0.0 & 1.2 \\
\hline \multicolumn{14}{|c|}{$\begin{array}{c}\text { OCS-G-6406 } \\
22,738 \mathrm{ft} .\end{array}$} \\
\hline Total & 322 & 61 & 17 & 313 & 61 & 26 & 9 & 2 & 16 & 43 & 12 & 0 & 5 \\
\hline Total/400 & 0.805 & 0.153 & 0.043 & 0.783 & 0.153 & 0.065 & 0.023 & 0.005 & 0.040 & 0.108 & 0.030 & 0.000 & 0.013 \\
\hline relative \% & 80.5 & 15.3 & 4.3 & 78.3 & 15.3 & 6.5 & 2.3 & 0.5 & 4.0 & 10.8 & 3.0 & 0.0 & 1.3 \\
\hline
\end{tabular}


Appendix 3. U-Pb Ages within Known Coeval Source Terranes.

Triassic Rifting
\begin{tabular}{|c|c|c|}
\hline Analysis & Best age & \pm \\
\hline & (Ma) & $(\mathrm{Ma})$ \\
\hline PE-57 & 202.1 & 16.7 \\
\hline \multicolumn{3}{|c|}{} \\
\hline DD-57 & 199.1 & 10.7 \\
\hline DD-26 & 212.1 & 14.1 \\
\hline
\end{tabular}

\begin{tabular}{|c|c|c|}
\hline \multicolumn{3}{|c|}{ Alleghanian (280-325 Ma) } \\
\hline Analysis & Best age & \pm \\
\hline & (Ma) & (Ma) \\
\hline MO-66 & 293.6 & 4.2 \\
\hline MO-44 & 327.1 & 6.4 \\
\hline P1004-44 & 283.5 & 4.2 \\
\hline P1004-10 & 305.7 & 8.2 \\
\hline P1080-20 & 295.7 & 3.8 \\
\hline P1080-7 & 296.0 & 3.2 \\
\hline PE-79 & 286.4 & 9.4 \\
\hline PE-55 & 289.8 & 4.0 \\
\hline $\mathrm{PE}-30$ & 291.4 & 3.1 \\
\hline PE-73 & 292.1 & 4.0 \\
\hline PE-20 & 292.6 & 10.1 \\
\hline $\mathrm{PE}-17$ & 293.9 & 2.7 \\
\hline $\mathrm{PE}-47$ & 297.9 & 5.6 \\
\hline PE-58 & 304.7 & 4.3 \\
\hline PE-68 & 309.3 & 15.2 \\
\hline PE-93 & 319.5 & 3.4 \\
\hline DD-51 & 273.8 & 5.8 \\
\hline DD-71 & 285.5 & 10.0 \\
\hline DD-89 & 300.7 & 7.7 \\
\hline DD-84 & 301.3 & 2.8 \\
\hline DD-29 & 309.6 & 3.4 \\
\hline DD-98 & 310.4 & 4.7 \\
\hline
\end{tabular}

\begin{tabular}{|c|c|c|c|c|c|}
\hline \multicolumn{6}{|c|}{ Acadian (374-425) } \\
\hline Analysis & Best age & \pm & Analysis & Best age & \pm \\
\hline & (Ma) & (Ma) & & (Ma) & (Ma) \\
\hline $1096-30$ & 375.5 & 4.4 & P1080-57 & 387.9 & 8.8 \\
\hline 1096-91 & 377.3 & 9.1 & P1080-81 & 389.2 & 3.7 \\
\hline $1096-84$ & 379.8 & 7.4 & P1080-38 & 392.2 & 22.0 \\
\hline 1096-65 & 390.2 & 34.2 & P1080-86 & 394.0 & 9.6 \\
\hline $1096-4$ & 412.8 & 19.0 & P1080-9 & 395.4 & 5.0 \\
\hline $1096-43$ & 424.7 & 5.0 & P1080-64 & 397.6 & 9.1 \\
\hline & & & P1080-96 & 397.9 & 15.4 \\
\hline & & & P1080-12 & 402.9 & 18.1 \\
\hline & & & P1080-71 & 407.7 & 5.7 \\
\hline MO-61 & 376.3 & 6.3 & P1080-84 & 415.9 & 4.7 \\
\hline MO- 91 & 379.5 & 9.2 & P1080-61 & 418.3 & 3.5 \\
\hline MO-4 & 380.6 & 7.3 & & & \\
\hline MO-25 & 390.9 & 4.6 & PE-24 & 425.4 & 6.1 \\
\hline MO- 90 & 394.0 & 6.1 & & & \\
\hline MO- 76 & 394.5 & 16.3 & DD-49 & 424.7 & 4.4 \\
\hline MO-7 & 405.6 & 3.4 & & & \\
\hline MO-63 & 412.8 & 5.7 & P1004-8 & 376.6 & 3.5 \\
\hline MO-15 & 417.0 & 6.6 & P1004-51 & 406.0 & 6.4 \\
\hline MO- 80 & 418.4 & 4.7 & P1004-33 & 410.4 & 4.7 \\
\hline MO-48 & 419.7 & 4.7 & P1004-89 & 411.5 & 8.9 \\
\hline MO- 88 & 422.2 & 8.3 & P1004-55 & 416.5 & 8.2 \\
\hline MO- 100 & 422.7 & 4.2 & P1004-74 & 425.0 & 5.5 \\
\hline
\end{tabular}

\begin{tabular}{|c|c|c|c|c|c|}
\hline \multicolumn{6}{|c|}{ Taconic (430-480 Ma) } \\
\hline Analysis & Best age & \pm & Analysis & Best age & \pm \\
\hline & (Ma) & (Ma) & & (Ma) & (Ma) \\
\hline $1096-29$ & 430.6 & 6.7 & P1004-27 & 469.0 & 5.4 \\
\hline $1096-49$ & 431.9 & 4.8 & & & \\
\hline $1096-41$ & 432.9 & 6.5 & & & \\
\hline $1096-22$ & 433.2 & 5.3 & & & \\
\hline $1096-54$ & 437.3 & 11.3 & P1080-83 & 436.5 & 5.3 \\
\hline $1096-23$ & 439.0 & 5.7 & P1080-31 & 438.4 & 5.3 \\
\hline $1096-15$ & 458.3 & 7.2 & P1080-98 & 442.4 & 3.8 \\
\hline $1096-61$ & 463.5 & 3.8 & P1080-35 & 442.9 & 9.3 \\
\hline $1096-46$ & 471.1 & 6.7 & P1080-55 & 449.0 & 6.3 \\
\hline & & & P1080-70 & 454.4 & 4.3 \\
\hline MO- 71 & 433.1 & 7.5 & P1080-99 & 455.5 & 8.5 \\
\hline MO-67 & 436.0 & 5.3 & P1080-73 & 457.2 & 29.2 \\
\hline MO- 89 & 439.1 & 11.9 & P1080-54 & 459.4 & 8.4 \\
\hline MO-24 & 450.2 & 6.4 & P1080-22 & 460.7 & 31.7 \\
\hline MO-60 & 450.3 & 8.4 & & & \\
\hline MO-58 & 456.4 & 2.8 & FMG-92 & 473.4 & 30.9 \\
\hline MO-1 & 480.2 & 4.1 & & & \\
\hline & & & DD-11 & 429.7 & 6.2 \\
\hline $\mathrm{PE}-75$ & 430.0 & 5.6 & DD-39 & 444.2 & 7.1 \\
\hline PE-48 & 431.9 & 3.7 & DD-1 & 469.5 & 9.6 \\
\hline
\end{tabular}




\begin{tabular}{|c|c|c|c|c|c|c|c|c|c|c|c|c|c|c|c|c|c|}
\hline \multicolumn{18}{|c|}{ Pan-African (500-680 Ma) } \\
\hline Analysis & Best age & \pm & Analysis & Best age & \pm & Analysis & Best age & \pm & Analysis & Best age & \pm & Analysis & Best age & \pm & Analysis & Best age & \pm \\
\hline & (Ma) & (Ma) & & (Ma) & (Ma) & & (Ma) & (Ma) & & (Ma) & (Ma) & & (Ma) & (Ma) & & $(\mathrm{Ma})$ & (Ma) \\
\hline $8304-46$ & 501.7 & 9.4 & $8304-81$ & 583.3 & 8.1 & $1096-72$ & 536.0 & 4.0 & P1004-79 & 557.3 & 15.0 & $8305-57$ & 550.0 & 9.3 & $8305-41$ & 637.9 & 5.8 \\
\hline 8304-78 & 525.6 & 7.3 & $8304-13$ & 586.2 & 13.1 & $1096-56$ & 546.7 & 10.0 & P1004-28 & 558.7 & 11.1 & $8305-83$ & 550.2 & 8.2 & $8305-82$ & 638.5 & 13.6 \\
\hline $8304-88$ & 526.2 & 24.8 & $8304-14$ & 599.3 & 7.7 & $1096-59$ & 569.6 & 5.6 & P1004-4 & 575.2 & 8.2 & $8305-48$ & 551.5 & 7.2 & $8305-46$ & 638.9 & 9.4 \\
\hline $8304-77$ & 532.2 & 9.5 & $8304-17$ & 603.6 & 11.8 & $1096-83$ & 584.0 & 5.9 & P1004-23 & 579.4 & 10.5 & $8305-3$ & 553.7 & 11.8 & $8305-77$ & 652.3 & 12.9 \\
\hline $8304-37$ & 544.6 & 5.7 & $8304-64$ & 604.9 & 7.9 & $1096-76$ & 589.3 & 9.3 & P1004-54 & 589.6 & 7.1 & $8305-47$ & 553.9 & 6.2 & $8305-11$ & 654.1 & 4.6 \\
\hline $8304-25$ & 545.3 & 4.4 & $8304-75$ & 605.2 & 6.4 & $1096-39$ & 591.3 & 25.7 & P1004-47 & 612.3 & 5.6 & $8305-91$ & 554.7 & 6.5 & $8305-95$ & 658.4 & 8.0 \\
\hline $8304-62$ & 548.0 & 8.8 & 8304-39 & 618.8 & 5.0 & $1096-48$ & 603.6 & 10.6 & P1004-88 & 618.8 & 6.1 & $8305-49$ & 555.5 & 7.8 & $8305-13$ & 662.5 & 13.2 \\
\hline 8304-79 & 552.9 & 4.9 & $8304-58$ & 624.2 & 9.2 & $1096-74$ & 629.3 & 4.9 & P1004-17 & 619.2 & 8.1 & $8305-63$ & 557.2 & 11.0 & 8305-9 & 666.2 & 5.6 \\
\hline 8304-36 & 553.0 & 4.4 & $8304-100$ & 625.1 & 6.6 & $1096-89$ & 636.9 & 4.3 & P1004-42 & 621.1 & 5.2 & $8305-97$ & 558.9 & 11.9 & $8305-22$ & 678.1 & 7.2 \\
\hline 8304-56 & 553.0 & 13.6 & $8304-80$ & 625.5 & 8.4 & & & & P1004-64 & 621.7 & 12.2 & $8305-58$ & 558.9 & 6.7 & & & \\
\hline $8304-53$ & 554.7 & 11.1 & $8304-65$ & 633.7 & 12.0 & P1080-41 & 542.1 & 14.6 & P1004-36 & 638.4 & 8.7 & $8305-43$ & 560.1 & 16.4 & FMG-90 & 533.6 & 4.8 \\
\hline $8304-57$ & 554.8 & 6.1 & $8304-15$ & 638.1 & 23.7 & P1080-58 & 550.9 & 6.9 & P1004-45 & 649.3 & 42.8 & $8305-8$ & 560.6 & 7.8 & FMG-78 & 542.6 & 16.6 \\
\hline $8304-40$ & 555.9 & 6.0 & 8304-76 & 640.6 & 10.3 & P1080-97 & 557.9 & 6.5 & & & & $8305-30$ & 561.5 & 11.1 & FMG-75 & 545.8 & 7.8 \\
\hline $8304-6$ & 556.1 & 23.3 & $8304-50$ & 642.0 & 6.5 & P1080-43 & 560.4 & 5.3 & $8305-18$ & 526.2 & 4.9 & $8305-37$ & 563.5 & 8.6 & FMG-46 & 547.1 & 7.1 \\
\hline $8304-28$ & 556.3 & 17.7 & $8304-12$ & 645.9 & 5.0 & P1080-69 & 584.0 & 9.7 & $8305-7$ & 531.1 & 11.7 & $8305-94$ & 564.6 & 13.8 & FMG-79 & 547.5 & 11.9 \\
\hline $8304-26$ & 556.9 & 5.0 & $8304-61$ & 648.3 & 11.9 & $\mathrm{P} 1080-2$ & 606.6 & 10.7 & $8305-39$ & 535.8 & 3.4 & $8305-56$ & 567.7 & 13.2 & FMG-26 & 547.7 & 7.5 \\
\hline $8304-93$ & 560.3 & 11.5 & & & & P1080-59 & 616.1 & 7.8 & $8305-67$ & 540.6 & 8.6 & $8305-61$ & 571.8 & 7.3 & FMG-64 & 551.1 & 6.4 \\
\hline $8304-99$ & 562.5 & 8.4 & & & & P1080-98 & 633.8 & 8.1 & $8305-26$ & 540.9 & 6.6 & $8305-4$ & 576.9 & 17.9 & FMG-89 & 552.0 & 4.5 \\
\hline $8304-41$ & 563.7 & 6.9 & MO-68 & 566.4 & 6.2 & P1080-62 & 635.1 & 11.8 & $8305-50$ & 542.1 & 12.7 & $8305-99$ & 600.3 & 11.2 & FMG-96 & 555.9 & 7.5 \\
\hline $8304-86$ & 567.2 & 6.8 & MO-38 & 582.0 & 9.4 & P1080-42 & 641.5 & 6.7 & $8305-15$ & 542.4 & 4.6 & $8305-28$ & 613.0 & 6.0 & FMG-73 & 557.9 & 7.3 \\
\hline 8304-18 & 568.7 & 14.4 & MO-51 & 591.9 & 7.8 & P1080-26 & 648.4 & 15.5 & $8305-69$ & 547.3 & 5.7 & $8305-86$ & 618.5 & 6.3 & FMG-84 & 561.6 & 4.3 \\
\hline $8304-82$ & 570.3 & 9.0 & MO-5 & 624.5 & 8.2 & & & & $8305-90$ & 548.1 & 5.1 & $8305-35$ & 623.0 & 7.3 & FMG-58 & 565.0 & 7.7 \\
\hline 8304-66 & 570.8 & 11.6 & MO-31 & 626.1 & 4.5 & P1004-53 & 545.9 & 7.4 & $8305-98$ & 549.6 & 11.1 & $8305-88$ & 628.1 & 4.1 & FMG-27 & 565.2 & 3.9 \\
\hline $8304-47$ & 575.4 & 9.7 & MO-16 & 642.0 & 6.7 & P1004-48 & 546.9 & 7.2 & $8305-89$ & 549.9 & 4.6 & $8305-14$ & 628.6 & 6.3 & FMG-82 & 566.8 & 6.5 \\
\hline
\end{tabular}




\begin{tabular}{|c|c|c|c|c|c|c|c|c|c|c|c|c|c|c|c|c|c|c|c|c|}
\hline \multicolumn{21}{|c|}{$00-680 \mathrm{Ma}$} \\
\hline Analysis & Best age & \pm & Analysis & Best age & \pm & Analysis & Best age & \pm & Analysis & Best age & \pm & Analysis & Best age & \pm & Analysis & Best age & \pm & Analysis & Best age & \pm \\
\hline & $(\mathrm{Ma})$ & (Ma) & & (Ma) & (Ma) & & (Ma) & (Ma) & & (Ma) & (Ma) & & (Ma) & (Ma) & & (Ma) & (Ma) & & (Ma) & (Ma) \\
\hline FMG-57 & 567.1 & 5.6 & FMG-40 & 619.2 & 10.3 & PE-52 & 551.6 & 6.8 & PE-34 & 652.9 & 2.5 & DD-43 & 604.7 & 6.9 & STPB-79 & 553.4 & 9.8 & STPB-99 & 572.6 & 7.1 \\
\hline FMG-51 & 567.5 & 3.9 & FMG-9 & 620.7 & 24.7 & PE-77 & 553.1 & 8.3 & & & & DD-67 & 614.7 & 15.9 & STPB-74 & 553.9 & 8.6 & STPB-22 & 575.0 & 18.6 \\
\hline FMG-65 & 568.5 & 8.4 & FMG-15 & 622.6 & 9.4 & PE-51 & 553.9 & 14.7 & DD-86 & 504.2 & 4.6 & DD-8 & 615.8 & 4.0 & STPB-65 & 554.5 & 3.0 & STPB-64 & 575.2 & 18.0 \\
\hline FMG-70 & 569.4 & 8.5 & FMG-39 & 623.5 & 28.2 & PE-94 & 557.7 & 15.9 & DD-73 & 522.3 & 50.0 & DD-95 & 622.6 & 5.0 & STPB-34 & 555.2 & 8.0 & STPB- 51 & 577.6 & 6.6 \\
\hline FMG-25 & 569.7 & 6.7 & FMG-97 & 626.0 & 10.2 & PE-50 & 561.8 & 5.6 & DD-14 & 533.2 & 10.1 & DD-62 & 630.6 & 14.2 & STPB-35 & 556.8 & 4.8 & STPB-7 & 578.7 & 16.7 \\
\hline FMG-36 & 569.9 & 6.1 & FMG-99 & 627.4 & 5.6 & PE-71 & 566.2 & 9.8 & DD-33 & 536.0 & 14.5 & DD-23 & 646.0 & 5.8 & STPB-1 & 557.2 & 8.3 & STPB-31 & 582.1 & 7.0 \\
\hline FMG-87 & 570.2 & 9.3 & FMG-35 & 629.6 & 9.4 & PE-56 & 567.2 & 7.4 & DD-75 & 537.7 & 33.6 & $\mathrm{DD}-22$ & 649.1 & 10.3 & STPB-91 & 557.2 & 13.9 & STPB-29 & 582.1 & 7.4 \\
\hline FMG-28 & 570.3 & 5.5 & FMG-16 & 630.6 & 9.4 & PE-53 & 570.1 & 20.8 & DD-3 & 539.1 & 5.4 & & & & STPB-55 & 557.3 & 7.0 & STPB-90 & 583.4 & 9.2 \\
\hline FMG-6 & 571.4 & 10.2 & FMG-61 & 633.0 & 9.1 & PE-46 & 571.9 & 6.7 & DD-74 & 541.3 & 11.1 & STPB-60 & 516.0 & 4.3 & STPB-89 & 557.4 & 6.8 & STPB-23 & 597.9 & 44.2 \\
\hline FMG-42 & 571.8 & 8.2 & FMG-85 & 633.3 & 9.4 & PE-74 & 572.4 & 5.5 & DD-79 & 543.8 & 6.1 & STPB-88 & 529.2 & 5.8 & STPB-62 & 557.6 & 3.1 & STPB-71 & 599.7 & 9.7 \\
\hline FMG-21 & 572.9 & 6.4 & FMG-33 & 637.9 & 4.7 & PE-60 & 575.7 & 5.8 & DD-46 & 544.2 & 4.4 & STPB-18 & 532.4 & 4.4 & STPB- 86 & 558.8 & 11.4 & STPB -43 & 603.0 & 8.1 \\
\hline FMG-37 & 573.7 & 14.0 & FMG-29 & 644.8 & 6.4 & PE-39 & 590.4 & 15.6 & DD-69 & 548.1 & 7.2 & STPB-57 & 534.6 & 5.0 & STPB- 47 & 559.1 & 19.8 & STPB-12 & 615.3 & 4.1 \\
\hline FMG-12 & 576.1 & 18.8 & FMG-24 & 656.3 & 38.1 & PE-43 & 591.6 & 21.2 & DD-34 & 559.5 & 10.0 & STPB-11 & 536.0 & 39.1 & STPB-78 & 560.2 & 8.3 & STPB-59 & 616.7 & 9.4 \\
\hline FMG-14 & 578.5 & 9.8 & FMG-50 & 657.9 & 4.6 & PE-59 & 592.3 & 6.2 & DD-70 & 562.8 & 13.3 & STPB-61 & 536.6 & 12.0 & STPB-10 & 561.3 & 10.9 & STPB-50 & 619.7 & 13.7 \\
\hline FMG-76 & 578.6 & 9.9 & FMG-19 & 666.1 & 16.5 & PE-44 & 608.1 & 13.4 & DD-50 & 563.7 & 11.2 & STPB-69 & 536.8 & 11.0 & STPB-85 & 561.7 & 8.5 & STPB-93 & 624.7 & 11.8 \\
\hline FMG-93 & 581.3 & 9.1 & & & & PE-70 & 609.6 & 8.7 & DD-76 & 572.6 & 9.6 & STPB-72 & 538.6 & 9.0 & STPB-27 & 561.8 & 5.8 & STPB-75 & 627.2 & 11.6 \\
\hline FMG-67 & 583.1 & 9.2 & PE-78 & 525.6 & 5.3 & PE- 84 & 620.1 & 8.9 & DD-64 & 573.6 & 11.3 & STPB- 83 & 540.3 & 9.2 & STPB-52 & 562.4 & 7.1 & STPB-42 & 630.8 & 8.0 \\
\hline FMG-22 & 587.1 & 13.9 & PE-91 & 531.2 & 6.6 & PE-83 & 623.9 & 4.5 & DD-56 & 581.8 & 7.6 & STPB-49 & 544.6 & 5.4 & STPB-62 & 563.1 & 4.1 & STPB-14 & 638.0 & 4.6 \\
\hline FMG-11 & 595.2 & 5.3 & PE-5 & 533.9 & 11.9 & PE-8 & 624.0 & 15.9 & DD-42 & 591.8 & 13.7 & STPB-2 & 545.8 & 29.3 & STPB-76 & 563.8 & 20.8 & STPB-41 & 640.3 & 8.4 \\
\hline FMG-34 & 596.3 & 6.4 & PE-9 & 543.3 & 19.3 & PE-45 & 624.4 & 9.9 & DD-37 & 592.2 & 10.4 & STPB-5 & 546.6 & 7.4 & STPB-21 & 564.1 & 9.8 & STPB-9 & 643.1 & 6.5 \\
\hline FMG-69 & 596.4 & 9.7 & PE-54 & 546.1 & 8.0 & PE-21 & 625.6 & 5.3 & DD-55 & 597.6 & 10.4 & STPB-44 & 547.1 & 6.1 & STPB-45 & 564.8 & 5.5 & STPB-82 & 645.6 & 9.9 \\
\hline FMG-44 & 610.8 & 14.1 & PE-23 & 549.0 & 10.7 & PE-6 & 628.2 & 8.1 & DD-66 & 598.4 & 8.7 & STPB-39 & 549.6 & 9.5 & STPB-68 & 566.8 & 12.2 & STPB-37 & 645.6 & 8.6 \\
\hline FMG-86 & 617.5 & 9.3 & PE-64 & 550.8 & 7.1 & PE-25 & 628.3 & 12.6 & DD-81 & 600.3 & 4.4 & STPB-80 & 550.5 & 7.0 & STPB-38 & 567.9 & 9.7 & STPB-94 & 649.1 & 6.5 \\
\hline FMG-72 & 617.8 & 3.7 & PE-81 & 551.1 & 8.4 & PE-66 & 632.1 & 7.0 & DD-96 & 604.3 & 3.9 & STPB-67 & 552.3 & 24.2 & STPB-100 & 569.4 & 21.6 & STPB-87 & 650.8 & 12.0 \\
\hline
\end{tabular}




\begin{tabular}{|c|c|c|c|c|c|c|c|c|c|c|c|c|c|c|c|c|c|}
\hline Analysis & Best age & \pm & Analysis & Best age & \pm & Analysis & Best age & \pm & Analysis & Best age & \pm & Analysis & Best age & \pm & Analysis & Best age & \pm \\
\hline & (Ma) & (Ma) & & (Ma) & (Ma) & & (Ma) & (Ma) & & (Ma) & (Ma) & & (Ma) & (Ma) & & (Ma) & (Ma) \\
\hline $1096-20$ & 939.6 & 65.7 & $1096-31$ & 1093.1 & 6.6 & MO-57 & 1019.0 & 11.3 & MO-54 & 1152.9 & 10.8 & P1004-58 & 1033.7 & 45.8 & P1004-40 & 1157.0 & 22.8 \\
\hline $1096-37$ & 962.0 & 62.9 & $1096-64$ & 1121.0 & 22.2 & MO-59 & 1020.8 & 62.7 & MO-2 & 1154.4 & 4.2 & P1004-96 & 1035.1 & 25.8 & P1004-30 & 1164.9 & 13.3 \\
\hline $1096-38$ & 985.6 & 56.3 & $1096-95$ & 1136.3 & 89.7 & MO-29 & 1027.1 & 134.0 & MO- 77 & 1163.6 & 4.3 & P1004-70 & 1040.0 & 38.5 & P1004-75 & 1169.1 & 66.7 \\
\hline $1096-82$ & 992.2 & 42.4 & $1096-35$ & 1139.1 & 10.9 & MO-37 & 1038.9 & 22.5 & MO-6 & 1164.1 & 7.2 & P1004-60 & 1045.3 & 28.2 & P1004-95 & 1180.5 & 5. \\
\hline $1096-86$ & 1004.8 & 58.9 & $1096-77$ & 1142.5 & 52.0 & MO-10 & 1042.9 & 61.4 & MO-22 & 1168.5 & 13.9 & P1004-21 & 1054.1 & 22.0 & P1004-34 & 1185.4 & 81.1 \\
\hline $1096-63$ & 1008.8 & 67.7 & $1096-42$ & 1153.8 & 24.4 & MO-19 & 1043.7 & 21.9 & MO- 86 & 1179.3 & 21.3 & P1004-80 & 1056.9 & 24.5 & P1004-38 & 1189.4 & 27.1 \\
\hline $1096-1$ & 1010.0 & 15.6 & $1096-51$ & 1155.5 & 7.2 & MO-39 & 1045.8 & 25.1 & MO-30 & 1189.7 & 22.3 & P1004-92 & 1060.3 & 31.7 & P1004-97 & 1224.9 & 56.4 \\
\hline 1096-92 & 1010.8 & 49.2 & $1096-60$ & 1157.5 & 131.5 & MO- 82 & 1046.4 & 69.6 & MO-14 & 1213.2 & 13.2 & P1004-59 & 1063.0 & 45.4 & P1004-62 & 1231.8 & 15.7 \\
\hline $1096-97$ & 1012.5 & 9.2 & $1096-32$ & 1166.7 & 25.3 & MO-20 & 1059.4 & 7.3 & MO-56 & 1235.7 & 7.3 & P1004-93 & 1063.3 & 18.8 & P1004-50 & 1239.2 & 4.2 \\
\hline $1096-88$ & 1014.6 & 34.5 & $1096-57$ & 1167.8 & 14.8 & MO-49 & 1060.6 & 51.8 & MO-35 & 1272.0 & 59.2 & P1004-9 & 1065.2 & 37.6 & P1004-12 & 1256.2 & 41.6 \\
\hline $1096-13$ & 1026.9 & 33.4 & $1096-36$ & 1171.2 & 65.7 & MO-27 & 1067.2 & 12.0 & MO-23 & 1275.0 & 27.8 & P1004-15 & 1067.2 & 9.9 & P1004-35 & 1261.6 & 28.4 \\
\hline $1096-50$ & 1029.5 & 28.2 & $1096-45$ & 1217.3 & 17.9 & MO-21 & 1072.9 & 19.0 & & & & P1004-41 & 1069.7 & 17.5 & P1004-77 & 1286.3 & 36.2 \\
\hline $1096-8$ & 1030.2 & 29.7 & $1096-98$ & 1289.7 & 12.4 & MO- 81 & 1077.6 & 12.1 & P1004-52 & 925.3 & 55.1 & P1004-61 & 1071.0 & 77.6 & P1004-14 & 1294.9 & 21.2 \\
\hline $1096-53$ & 1030.6 & 63.0 & & & & MO-52 & 1096.3 & 58.2 & P1004-67 & 934.7 & 24.1 & P1004-49 & 1077.1 & 48.3 & $\mathrm{P} 1004-20$ & 1296.3 & 52.5 \\
\hline $1096-79$ & 1039.2 & 23.6 & MO-9 & 923.5 & 92.8 & MO-64 & 1110.4 & 140.1 & P1004-91 & 956.1 & 40.6 & P1004-69 & 1081.0 & 14.5 & & & \\
\hline $1096-3$ & 1044.1 & 43.5 & MO- 73 & 954.0 & 98.4 & MO- 99 & 1115.5 & 24.5 & P1004-56 & 968.6 & 97.6 & P1004-100 & 1082.1 & 40.1 & P1080-8 & 940.5 & 103.0 \\
\hline 1096-19 & 1046.3 & 33.5 & MO-3 & 961.8 & 37.9 & MO- 75 & 1117.5 & 26.8 & P1004-66 & 975.1 & 34.9 & P1004-81 & 1092.1 & 16.3 & P1080-37 & 986.6 & 46.1 \\
\hline $1096-6$ & 1052.5 & 14.5 & MO- 74 & 966.8 & 40.8 & MO-17 & 1117.7 & 22.1 & P1004-73 & 989.1 & 16.2 & P1004-85 & 1093.1 & 34.7 & $\mathrm{P} 1080-56$ & 988.4 & 83.9 \\
\hline $1096-87$ & 1052.6 & 8.6 & MO-13 & 971.7 & 25.6 & MO- 95 & 1126.6 & 23.1 & P1004-1 & 1013.7 & 17.3 & P1004-16 & 1097.0 & 28.8 & P1080-1 & 994.6 & 120.4 \\
\hline $1096-78$ & 1070.4 & 20.0 & MO-41 & 978.7 & 12.4 & MO-65 & 1127.1 & 27.7 & P1004-98 & 1016.4 & 27.3 & P1004-3 & 1105.0 & 24.2 & P1080-68 & 998.7 & 14.4 \\
\hline $1096-52$ & 1074.7 & 21.6 & MO-33 & 1011.0 & 10.2 & MO-46 & 1129.3 & 22.7 & P1004-43 & 1019.2 & 7.0 & P1004-87 & 1110.2 & 10.4 & P1080-91 & 1003.8 & 49.7 \\
\hline $1096-71$ & 1082.2 & 31.7 & MO-34 & 1015.8 & 63.9 & MO- 83 & 1132.6 & 13.8 & P1004-22 & 1024.5 & 37.5 & P1004-82 & 1115.4 & 21.5 & $\mathrm{P} 1080-25$ & 1020.2 & 83.4 \\
\hline $1096-55$ & 1082.3 & 29.5 & MO-43 & 1017.7 & 51.8 & MO-26 & 1138.6 & 46.8 & P1004-72 & 1026.5 & 14.8 & P1004-63 & 1124.5 & 46.2 & $\mathrm{P} 1080-40$ & 1027.3 & 38.2 \\
\hline $1096-12$ & 1086.7 & 4.5 & MO-53 & 1019.0 & 32.2 & MO- 98 & 1143.9 & 7.5 & P1004-76 & 1032.4 & 25.2 & P1004-11 & 1139.3 & 8.6 & P1080-4 & 1028.7 & $12 . c$ \\
\hline
\end{tabular}




\begin{tabular}{|c|c|c|c|c|c|c|c|c|}
\hline Analysis & Best age & \pm & Analysis & Best age & \pm & Analysis & Best age & \pm \\
\hline & (Ma) & (Ma) & & (Ma) & (Ma) & & (Ma) & (Ma) \\
\hline P1080-94 & 1038.2 & 68.4 & PE-65 & 1011.2 & 22.8 & DD-15 & 1046.2 & 3.6 \\
\hline P1080-46 & 1049.3 & 18.9 & PE-22 & 1029.2 & 37.2 & DD-7 & 1065.9 & 42.3 \\
\hline P1080-47 & 1065.0 & 26.2 & PE-27 & 1031.3 & 31.0 & DD-65 & 1082.5 & 15.5 \\
\hline P1080-10 & 1065.3 & 93.2 & PE-87 & 1036.8 & 34.0 & DD-91 & 1108.5 & 42.2 \\
\hline P1080-49 & 1066.5 & 28.1 & PE-40 & 1047.0 & 61.3 & DD-4 & 1167.5 & 59.9 \\
\hline P1080-60 & 1066.8 & 24.5 & PE-85 & 1067.1 & 17.2 & DD-36 & 1178.6 & 30.3 \\
\hline P1080-16 & 1071.8 & 48.2 & PE-98 & 1142.7 & 34.1 & DD-17 & 1179.1 & 8.5 \\
\hline P1080-34 & 1087.6 & 14.6 & PE-2 & 1178.1 & 18.8 & DD-38 & 1202.8 & 27.8 \\
\hline P1080-78 & 1090.4 & 149.2 & PE-1 & 1186.0 & 48.7 & DD-25 & 1204.5 & 17.5 \\
\hline P1080 prob 51 & 1139.9 & 23.3 & PE-15 & 1196.8 & 36.5 & DD-99 & 1226.6 & 20.2 \\
\hline P1080-21 & 1142.0 & 11.2 & PE-100 & 1204.0 & 35.7 & DD-31 & 1275.5 & 23.1 \\
\hline P1080-76 & 1152.0 & 18.4 & PE-49 & 1214.3 & 20.2 & DD-48 & 1283.4 & 72.1 \\
\hline P1080-36 & 1169.2 & 20.0 & PE-69 & 1221.2 & 5.9 & & & \\
\hline P1080-63 & 1173.7 & 18.6 & PE-62 & 1222.7 & 8.0 & & & \\
\hline P1080-77 & 1194.0 & 54.4 & PE-3 & 1231.1 & 8.5 & & & \\
\hline P1080-92 & 1196.4 & 10.5 & PE-80 & 1242.3 & 9.5 & & & \\
\hline P1080-74 & 1221.4 & 24.0 & PE-76 & 1285.3 & 42.1 & & & \\
\hline P1080-82 & 1237.8 & 12.6 & & & & & & \\
\hline P1080-95 & 1238.1 & 32.7 & DD-78 & 1001.0 & 116.1 & & & \\
\hline P1080-3 & 1290.0 & 4.7 & DD-20 & 1006.7 & 44.1 & & & \\
\hline & & & DD-44 & 1023.0 & 20.0 & & & \\
\hline PE-11 & 923.5 & 91.1 & DD-59 & 1026.3 & 24.8 & & & \\
\hline PE-10 & 967.7 & 15.4 & DD-5 & 1035.3 & 15.9 & & & \\
\hline PE-18 & 978.7 & 4.5 & DD-47 & 1045.6 & 38.9 & & & \\
\hline
\end{tabular}




\begin{tabular}{|c|c|c|c|c|c|}
\hline Analysis & Best age & \pm & Analysis & Best age & \pm \\
\hline & (Ma) & (Ma) & & (Ma) & (Ma) \\
\hline $1096-5$ & 1310.5 & 46.2 & P1080-48 & 1320.0 & 11.9 \\
\hline 1096-18 & 1312.9 & 21.8 & P1080-52 & 1327.8 & 34.4 \\
\hline $1096-100$ & 1326.3 & 11.4 & P1080-14 & 1334.8 & 13.5 \\
\hline $1096-67$ & 1344.9 & 24.4 & P1080-89 & 1387.8 & 17.2 \\
\hline $1096-2$ & 1382.3 & 15.1 & P1080-32 & 1389.6 & 44.0 \\
\hline $1096-21$ & 1402.2 & 11.5 & P1080-50 & 1454.0 & 10.4 \\
\hline \multirow[t]{3}{*}{ 1096-44 } & 1466.5 & 13.0 & P1080-27 & 1490.6 & 8.7 \\
\hline & & & DD-97 & 1306.0 & 70.8 \\
\hline & & & DD-82 & 1319.2 & 19.1 \\
\hline P1004-2 & 1308.0 & 47.4 & DD-54 & 1419.0 & 10.2 \\
\hline P1004-31 & 1319.4 & 8.5 & DD-24 & 1452.9 & 21.6 \\
\hline P1004-32 & 1329.3 & 27.3 & & & \\
\hline P1004-78 & 1363.4 & 154.4 & MO-62 & 1302.5 & 13.2 \\
\hline P1004-5 & 1380.8 & 19.1 & MO- 97 & 1304.9 & 19.4 \\
\hline P1004-37 & 1391.9 & 37.1 & MO- 92 & 1322.3 & 13.7 \\
\hline P1004-24 & 1392.6 & 67.3 & MO- 84 & 1323.9 & 35.2 \\
\hline P1004-71 & 1476.1 & 12.6 & MO-28 & 1398.2 & 33.9 \\
\hline P1004-19 & 1488.4 & 19.6 & MO-47 & 1458.9 & \\
\hline
\end{tabular}

\begin{tabular}{|c|c|c|c|c|c|c|c|c|}
\hline Analysis & Best age & \pm & Analysis & Best age & \pm & Analysis & Best age & \pm \\
\hline & (Ma) & (Ma) & & (Ma) & (Ma) & & (Ma) & (Ma) \\
\hline 8304-72 & 982.1 & 18.6 & $8305-2$ & 1198.9 & 30.4 & STPB-56 & 1148.6 & 23.9 \\
\hline $8304-97$ & 983.4 & 14.1 & $8305-85$ & 1208.0 & 20.4 & STPB-28 & 1225.2 & 15.7 \\
\hline $8304-3$ & 987.1 & 10.0 & $8305-19$ & 1218.1 & 37.7 & STPB-95 & 1239.5 & 19.9 \\
\hline $8304-10$ & 1012.3 & 18.7 & $8305-92$ & 1218.6 & 8.8 & STPB-40 & 1243.2 & 18.7 \\
\hline $8304-45$ & 1029.7 & 17.9 & $8305-87$ & 1222.9 & 25.7 & STPB-66 & 1351.7 & 31.2 \\
\hline $8304-43$ & 1050.5 & 29.4 & $8305-23$ & 1227.1 & 25.0 & STPB-97 & 1358.5 & 7.6 \\
\hline $8304-96$ & 1071.9 & 7.0 & $8305-60$ & 1231.8 & 18.5 & & & \\
\hline $8304-85$ & 1097.9 & 8.2 & $8305-65$ & 1232.2 & 89.5 & & & \\
\hline 8304-24 & 1137.1 & 14.8 & $8305-45$ & 1246.9 & 41.0 & & & \\
\hline $8304-30$ & 1187.2 & 10.4 & $8305-81$ & 1252.5 & 38.9 & & & \\
\hline 8304-22 & 1341.6 & 12.0 & $8305-20$ & 1256.9 & 17.1 & & & \\
\hline $8304-83$ & 1357.2 & 8.1 & $8305-55$ & 1273.4 & 24.9 & & & \\
\hline 8304-32 & 1392.5 & 34.8 & $8305-5$ & 1277.0 & 74.5 & & & \\
\hline & & & $8305-70$ & 1326.2 & 31.7 & & & \\
\hline $8305-100$ & 978.9 & 41.5 & $8305-52$ & 1329.0 & 40.0 & & & \\
\hline $8305-78$ & 980.9 & 22.3 & $8305-79$ & 1408.5 & 24.4 & & & \\
\hline $8305-12$ & 1016.7 & 11.0 & & & & & & \\
\hline $8305-25$ & 1035.0 & 37.5 & FMG-32 & 1021.0 & 11.2 & & & \\
\hline $8305-93$ & 1035.2 & 12.7 & FMG-2 & 1066.9 & 7.0 & & & \\
\hline $8305-73$ & 1045.1 & 26.0 & FMG-98 & 1221.6 & 21.9 & & & \\
\hline $8305-51$ & 1102.0 & 24.5 & FMG-80 & 1259.1 & 59.5 & & & \\
\hline $8305-27$ & 1131.3 & 33.1 & & & & & & \\
\hline $8305-80$ & 1140.7 & 37.0 & STPB-46 & 985.3 & 26.9 & & & \\
\hline $8305-16$ & 1154.7 & 38.7 & STPB-36 & 1129.1 & 73.3 & & & \\
\hline
\end{tabular}

Yavapai Mazatzal (1600-1800 Ma)
\begin{tabular}{|c|c|c|}
\hline Analysis & Best age & \pm \\
\hline & (Ma) & (Ma) \\
\hline $1096-16$ & 1619.7 & 8.8 \\
\hline \multicolumn{3}{|c|}{} \\
\hline MO- 85 & 1655.1 & 8.6 \\
\hline MO-40 & 1677.0 & 7.1 \\
\hline \multicolumn{3}{|c|}{} \\
\hline P1080-6 & 1625.9 & 24.0 \\
\hline P1080-87 & 1642.1 & 22.5 \\
\hline P1080-44 & 1679.1 & 16.9 \\
\hline \multicolumn{3}{|c|}{} \\
\hline DD-90 & 1623.4 & 6.6 \\
\hline
\end{tabular}




\begin{tabular}{|c|c|c|c|c|c|c|c|c|c|c|c|}
\hline Analysis & Best age & \pm & Analysis & Best age & \pm & Analysis & Best age & \pm & Analysis & Best age & \pm \\
\hline & (Ma) & (Ma) & & (Ma) & (Ma) & & (Ma) & (Ma) & & (Ma) & (Ma) \\
\hline $1096-80$ & 2137.4 & 10.1 & 8305-59 & 2090.9 & 10.5 & PE-89 & 1995.7 & 10.6 & STPB-58 & 2030.9 & 23.3 \\
\hline & & & $8305-6$ & 2133.2 & 2.8 & PE-28 & 2029.7 & 17.0 & STPB-3 & 2051.9 & 16.0 \\
\hline $8304-74$ & 1919.4 & 27.7 & 8305-42 & 2156.0 & 5.8 & PE-37 & 2033.8 & 6.2 & STPB-70 & 2063.4 & 6.6 \\
\hline $8304-68$ & 1972.2 & 19.6 & & & & PE-99 & 2064.7 & 15.5 & STPB-32 & 2103.0 & 5.9 \\
\hline $8304-87$ & 1987.4 & 9.3 & FMG-20 & 2038.0 & 4.6 & PE-41 & 2083.3 & 15.8 & STPB-96 & 2106.8 & 4.6 \\
\hline $8304-2$ & 1990.9 & 6.9 & FMG-66 & 2076.3 & 6.5 & PE-72 & 2096.4 & 8.0 & STPB-63 & 2120.3 & 4.6 \\
\hline $8304-54$ & 2023.3 & 5.7 & FMG-71 & 2084.1 & 11.9 & PE-7 & 2192.5 & 9.1 & STPB-73 & 2199.5 & 39.1 \\
\hline 8304-19 & 2065.9 & 15.0 & FMG-91 & 2093.1 & 10.2 & PE-92 & 2208.9 & 14.9 & STPB- 53 & 2219.7 & 7.0 \\
\hline $8304-16$ & 2067.5 & 12.7 & FMG-31 & 2103.4 & 8.9 & & & & & & \\
\hline $8304-20$ & 2092.4 & 5.5 & FMG-74 & 2126.4 & 4.9 & DD-94 & 2050.5 & 2.8 & & & \\
\hline $8304-1$ & 2096.5 & 3.3 & FMG-47 & 2188.7 & 11.2 & DD-61 & 2070.6 & 6.4 & & & \\
\hline 8304-31 & 2115.3 & 9.7 & & & & DD-6 & 2093.6 & 2.2 & & & \\
\hline $8304-8$ & 2121.2 & 2.3 & MO- 72 & 2090.8 & 7.8 & DD-32 & 2099.2 & 8.8 & & & \\
\hline $8304-98$ & 2123.4 & 6.1 & & & & DD-80 & 2102.7 & 6.5 & & & \\
\hline $8304-29$ & 2160.0 & 1.4 & P1004-84 & 1913.7 & 27.7 & DD-12 & 2108.1 & 10.5 & & & \\
\hline 8304-33 & 2189.1 & 3.8 & P1004-86 & 1985.1 & 60.0 & DD-63 & 2122.5 & 2.4 & & & \\
\hline 8304-9 & 2211.1 & 5.9 & P1004-83 & 2122.9 & 2.9 & DD-77 & 2136.3 & 7.3 & & & \\
\hline $8304-63$ & 2218.5 & 2.4 & P1004-7 & 2173.7 & 4.4 & DD-53 & 2152.1 & 6.7 & & & \\
\hline $8304-23$ & 2327.5 & 7.0 & & & & DD-68 & 2195.0 & 32.8 & & & \\
\hline 8304-42 & 2605.5 & 9.8 & & & & DD-16 & 2197.3 & 7.3 & & & \\
\hline & & & P1080-11 & 2064.2 & 24.4 & & & & & & \\
\hline $8305-84$ & 1990.8 & 5.6 & P1080-30 & 2126.0 & 2.9 & STPB-58 & 1959.6 & 21.1 & & & \\
\hline $8305-40$ & 2052.1 & 8.4 & P1080-75 & 2166.6 & 15.4 & STPB-25 & 1973.4 & 29.8 & & & \\
\hline $8305-24$ & 2065.2 & 9.7 & P1080-65 & 2167.0 & 6.5 & STPB-81 & 2002.0 & 13.5 & & & \\
\hline
\end{tabular}

\begin{tabular}{|c|c|c|}
\hline \multicolumn{3}{|c|}{ African Archaen Terrane (2450-3040 Ma) } \\
\hline Analysis & Best age & \pm \\
\hline & (Ma) & (Ma) \\
\hline $8305-21$ & 2447.1 & 7.5 \\
\hline $8305-66$ & 2799.8 & 3.7 \\
\hline P1004-26 & 2615.5 & 15.9 \\
\hline P1004-57 & 2673.2 & 19.5 \\
\hline $\mathrm{P} 1080-53$ & 2461.7 & 8.4 \\
\hline P1080-13 & 2481.5 & 6.2 \\
\hline PE-96 & 2766.6 & 3.7 \\
\hline DD-92 & 2641.3 & 1.6 \\
\hline DD-13 & 2704.3 & 10.4 \\
\hline STPB-74 & 2670.7 & 13.6 \\
\hline STPB-15 & 2771.1 & 4.8 \\
\hline FMG-41 & 2654.5 & 3.0 \\
\hline FMG-17 & 2735.1 & 3.9 \\
\hline FMG-62 & 2815.9 & 10.9 \\
\hline
\end{tabular}


Appendix 4. U-Pb Ages with Unknown Source Terranes.

\begin{tabular}{|c|c|c|c|c|c|c|c|c|c|c|c|c|c|c|}
\hline Analysis & Best age & \pm & Analysis & Best age & \pm & Analysis & Best age & \pm & Analysis & Best age & \pm & Analysis & Best age & \pm \\
\hline & (Ma) & (Ma) & & (Ma) & (Ma) & & (Ma) & (Ma) & & (Ma) & (Ma) & & (Ma) & (Ma) \\
\hline $1096-17$ & 330.9 & 6.9 & $8304-91$ & 1890.9 & 5.0 & MO- 79 & 367.3 & 7.1 & $\begin{array}{l}\text { P1080- } \\
24\end{array}$ & 2332.1 & 5.8 & DD-45 & 767.1 & 5.4 \\
\hline $1096-14$ & 342.1 & 7.7 & $8304-51$ & 1891.4 & 9.0 & MO-69 & 368.8 & 3.2 & & & & DD-41 & 2443.6 & 2.4 \\
\hline 1096-75 & 366.5 & 3.4 & & & & MO-11 & 370.8 & 5.2 & PE-36 & 409.7 & 5.2 & DD-35 & 3093.2 & 16.6 \\
\hline $1096-47$ & 482.7 & 7.9 & 8305-38 & 801.8 & 8.1 & MO- 93 & 426.0 & 3.9 & PE-14 & 412.1 & 3.6 & & & \\
\hline $1096-11$ & 485.3 & 3.1 & $8305-64$ & 890.2 & 83.9 & MO- 70 & 1803.5 & 26.1 & PE-32 & 414.1 & 18.9 & STPB-6 & 812.3 & 33.4 \\
\hline $1096-40$ & 487.0 & 8.2 & $8305-54$ & 1502.1 & 9.2 & $\mathrm{MO}-8$ & 2711.2 & 19.8 & PE-19 & 788.2 & 4.7 & $\begin{array}{l}\text { STPB- } \\
17\end{array}$ & 939.9 & 16.5 \\
\hline 1096-73 & 697.4 & 10.6 & $8305-72$ & 1507.6 & 21.9 & MO-12 & 3401.0 & 6.7 & PE-90 & 829.2 & 9.8 & $\begin{array}{l}\text { STPB- } \\
84\end{array}$ & 1795.9 & 26.8 \\
\hline 1096-85 & 1541.8 & 15.1 & 8305-34 & 1522.6 & 11.2 & & & & PE-38 & 841.6 & 7.0 & & & \\
\hline $1096-68$ & 1801.8 & 12.5 & $8305-44$ & 1697.4 & 40.2 & P1004-6 & 334.9 & 3.8 & PE-31 & 1546.8 & 4.5 & & & \\
\hline $1096-69$ & 1887.8 & 9.6 & $8305-77$ & 1757.4 & 28.7 & $\begin{array}{l}\text { P1004- } \\
68 \\
\end{array}$ & 373.0 & 3.2 & PE-33 & 1859.9 & 57.0 & & & \\
\hline & & & $8305-53$ & 1868.8 & 18.3 & $\begin{array}{l}\text { P1004- } \\
94\end{array}$ & 1511.6 & 21.3 & PE-16 & 1881.3 & 4.1 & & & \\
\hline $8304-84$ & 456.4 & 18.1 & $8305-75$ & 1885.7 & 6.0 & $\begin{array}{l}\text { P1004- } \\
39\end{array}$ & 1517.1 & 30.6 & PE-13 & 1884.5 & 11.7 & & & \\
\hline $8304-60$ & 492.5 & 7.3 & $8305-17$ & 2325.3 & 20.8 & $\begin{array}{l}\text { P1004- } \\
25\end{array}$ & 1534.5 & 24.1 & PE-86 & 2358.3 & 13.6 & & & \\
\hline $8304-94$ & 499.2 & 10.6 & & & & $\begin{array}{l}\text { P1004- } \\
29 \\
\end{array}$ & 1546.6 & 21.1 & PE-35 & 1747.6 & 3.5 & & & \\
\hline $8304-44$ & 725.6 & 23.4 & FMG-77 & 77.4 & 4.2 & & & & PE-67 & 1795.3 & 9.2 & & & \\
\hline 8304-71 & 814.9 & 15.5 & FMG-52 & 328.8 & 20.3 & $\begin{array}{l}\text { P1080- } \\
100\end{array}$ & 327.0 & 6.1 & & & & & & \\
\hline $8304-21$ & 875.6 & 14.3 & FMG-38 & 696.9 & 4.9 & $\begin{array}{l}\text { P1080- } \\
33\end{array}$ & 337.1 & 7.6 & DD-28 & 360.6 & 8.4 & & & \\
\hline 8304-69 & 1563.8 & 22.3 & FMG-7 & 718.3 & 9.5 & $\begin{array}{l}\text { P1080- } \\
93\end{array}$ & 365.4 & 15.9 & DD-88 & 370.4 & 11.2 & & & \\
\hline $8304-5$ & 1786.4 & 5.2 & $\begin{array}{l}\text { FMG- } \\
100 \\
\end{array}$ & 1752.4 & 11.9 & $\begin{array}{l}\text { P1080- } \\
17\end{array}$ & 427.0 & 5.7 & DD-10 & 404.2 & 3.1 & & & \\
\hline $8304-4$ & 1805.4 & 38.5 & FMG-88 & 1764.5 & 6.8 & $\begin{array}{l}\text { P1080- } \\
15\end{array}$ & 427.3 & 3.6 & DD-83 & 415.9 & 5.0 & & & \\
\hline $8304-90$ & 1820.2 & 14.8 & FMG-8 & 2300.9 & 18.2 & $\begin{array}{l}\text { P1080- } \\
18 \\
\end{array}$ & 483.4 & 3.3 & DD-58 & 489.5 & 17.8 & & & \\
\hline $8304-35$ & 1863.5 & 12.5 & & & & $\begin{array}{l}\text { P1080- } \\
72\end{array}$ & 686.9 & 18.8 & DD-19 & 689.2 & 27.0 & & & \\
\hline $8304-70$ & 1870.5 & 9.8 & MO- 78 & 344.0 & 8.4 & $\begin{array}{l}\text { P1080- } \\
88\end{array}$ & 1890.0 & 12.7 & DD-52 & 696.9 & 16.4 & & & \\
\hline
\end{tabular}

